VANESSA MELONI MASSARA

O PERFIL DA INFRA-ESTRUTURA NO MUNICÍPIO DE SÃO PAULO E SUA RELAÇÃO COM AS TRANSFORMAÇÕES DE USO DO SOLO: O CENTRO EXPANDIDO E A REGIÃO DE SÃO MIGUEL PAULISTA

\author{
Dissertação apresentada à Escola \\ Politécnica da Universidade de São \\ Paulo para obtenção do título de \\ Mestre em Engenharia.
}




\title{
O PERFIL DA INFRA-ESTRUTURA NO MUNICÍPIO DE SÃO PAULO E SUA RELAÇÃO COM AS TRANSFORMAÇÕES DE USO DO SOLO: O CENTRO EXPANDIDO E A REGIÃO DE SÃO MIGUEL PAULISTA
}

\author{
Dissertação apresentada à Escola \\ Politécnica da Universidade de São \\ Paulo para obtenção do título de \\ Mestre em Engenharia. \\ Área de Concentração: \\ Construção Civil e Urbana \\ Orientador: \\ Prof. Dr. Witold Zmitrowicz
}




\section{FICHA CATALOGRÁFICA}

Massara, Vanessa Meloni

O perfil da infra-estrutura no Município de São Paulo e sua relação com as transformações de uso do solo: o centro expandido e a região de São Miguel Paulista. São Paulo, 2002, 178p + CD-ROM.

Dissertação (Mestrado) - Escola Politécnica da Universidade de São Paulo. Departamento de Engenharia de Construção Civil.

1.Uso do solo 2.Saneamento São Paulo (SP) 3. Telecomunicações São Paulo (SP) 4.Energia São Paulo (SP)

I. Universidade de São Paulo. Escola Politécnica. Departamento de Engenharia de Construção Civil . 


\section{FOLHA DE APROVAÇÃO}

\section{Autor:}

Vanessa Meloni Massara

\section{Título:}

O perfil da infra-estrutura no Município de São Paulo e sua relação com as transformações de uso do solo: o centro expandido e a região de São Miguel Paulista

Natureza do Trabalho:

Dissertação (mestrado)

\section{Obtenção do Grau:}

Mestre em Engenharia Civil

Instituição:

Escola Politécnica da Universidade de São Paulo

Área de concentração:

Construção Civil e Urbana

\section{Data de aprovação:}

16 de outubro de 2002

\section{Banca examinadora:}

Prof. Dr. Witold Zmitrowicz

Professor Livre-Docente - Escola Politécnica da Universidade de São Paulo

Departamento de Engenharia de Construção Civil e Urbana

Parecer: aprovada

Profa. Dra. Monica Ferreira do Amaral Porto

Professora Livre-Docente - Escola Politécnica da Universidade de São Paulo

Departamento de Engenharia Hidráulica e Sanitária

Parecer: aprovada

Prof. Dr. José Alberto Quintanilha

Professor Doutor - Escola Politécnica da Universidade de São Paulo

Departamento de Engenharia de Transportes

Parecer: aprovada

Homologada em reunião da CPG de 21 de outubro de 2002.

(Ata de Defesa registrada à página 220 do Livro de dissertações e teses da EPUSP 2002.) 
Para minha mãe Glória e para meu pai Walter, por investirem no meu sonho de ser Engenheira Civil.

Para você, que acreditou em mim. 


\section{AGRADECIMENTOS}

Ao Prof. Dr. Witold Zmitrowicz a sabedoria, atenção e amizade na orientação desta pesquisa.

A Prof. Dra. Monica Ferreira do Amaral Porto e ao Prof. Dr. José Alberto Quintanilha, a importante colaboração para conclusão deste trabalho.

Ao Conselho Nacional de Desenvolvimento Científico e Tecnológico - CNPq, a bolsa de Mestrado.

Ao Professor Sérgio Leal Ferreira, as instruções sobre o uso do Programa Adobe photoshop.

Ao pessoal da sala asteróide, em especial aos colegas Sergio Cirelli Angulo, George Freire dos Santos e Rogerio Fonseca Santovito, a determinante colaboração com as figuras e o cd-rom e também aos colegas Leonardo Miranda, Rosa Crescencio, Evandro Bastos e Eduardo Ohashi, a ajuda no dia-a-dia.

Ao pessoal da secretaria do PCC, Fátima Domingues, Alcione Anaya, Cristina Solera e ao pessoal da computação, Patrícia de Freitas e Edson Oliveira, a atenção em todos os momentos. 


\section{Resumo}

Esta pesquisa pretende fornecer uma visão geral sobre a implantação das redes de infra-estrutura - saneamento, energia e telecomunicações - no Município de São Paulo, através da evolução de sua distribuição territorial ao longo do século XX e de informações sobre a expansão da capacidade dos sistemas oriunda dessa ampliação. Após esse breve histórico, fazemos um paralelo entre as transformações no uso do solo e a existência de infra-estrutura em duas áreas distintas: o centro expandido e a região de São Miguel Paulista. 


\begin{abstract}
This research intends to give a general view about the infrastructure net installation sanitation, energy and telecommunications - in the City of São Paulo, through the evolution of its distribution and the increase of its capacity across the $20^{\text {th }}$ century. After this review, we make a correlation between the land use transformations and the existence or not of infrastructure in two different areas: "centro expandido" and São Miguel Paulista.
\end{abstract}


Introdução........................................................................................................................

Objetivos

Aspectos metodológicos

Estruturação da Dissertação

1. Infra-estrutura e uso do solo - aspectos conceituais.................................................8

1.1. Infra-estrutura, serviços e equipamentos públicos

1.2. O desenvolvimento das cidades tendo como base uso do solo e infra-estrutura

1.3. Potencial de adensamento, valorização imobiliária e segregação urbana

2. Breve histórico sobre a evolução das redes de infra-estrutura do Município de São Paulo

2.1. Introdução: as redes de infra-estrutura no Mundo e no Brasil........................25

2.2. Saneamento básico..........................................................................................................30

2.2.1. Concessão dos serviços

2.2.2. Abastecimento de água

2.2.2.1. Distribuição territorial da rede

2.2.2.2. Mananciais

2.2.2.3. Distribuição: sub-adutoras, estações elevatórias e de tratamento

2.2.2.4. Distribuição: reservatórios, torres e setores de abastecimento

2.2.3. Coleta de esgotos. .51

2.2.3.1. Distribuição territorial da rede

2.2.3.2. Interceptores, coletores, estações elevatórias e de tratamento

\subsection{Energia}

2.3.1. A rede de gás. .61

2.3.1.1. Concessão dos serviços residencial

2.3.1.2.Distribuição territorial da rede: uso industrial, comercial e

2.3.2. Energia elétrica. 68

2.3.2.1. Concessão dos serviços

2.3.2.2. Distribuição territorial da rede: iluminação pública e uso privado

2.3.2.3. Sistema hidráulico e complexo gerador

2.3.2.4. Estações transformadoras de distribuição de energia

\subsection{Telecomunicações}

2.4.1.Telefonia.

2.4.1.1. Concessão dos serviços

2.4.1.2. Distribuição territorial da rede: telefones particulares e públicos

2.4.1.3. Centrais telefônicas

2.4.1.4. Telefonia celular

2.4.2. Cabo óptico.

2.4.2.1. Concessão dos serviços

2.4.2.2. Distribuição territorial da rede: agrupamento de cabos de telefonia e energia, otimização da transmissão de dados computacionais e tv a cabo

3. A implantação de infra-estrutura e as transformações no uso do solo: a região do centro expandido no período 1890 - 1999

3.1. A escolha da região do centro expandido...........................................................93

3.2.Características históricas.........................................................................................95

3.3.Características gerais da população e ocupação...................................................97

3.3.1. População 
3.3.2. Ocupação

3.4. Características gerais da infra-estrutura da região...................................101

3.4.1. Coleta de esgotos

3.4.2. Abastecimento de água

3.4.3. Iluminação pública

3.4.4. Energia elétrica

3.4.5. Gás canalizado

3.4.6. Telefonia

3.4.7. Cabo óptico

3.5. Infra-estrutura e uso do solo no centro expandido

3.5.1. Período 1890 - 1922

3.5.2. Período $1922-1952$

3.5.3. Período 1952-1972

3.5.4. Período 1972 - 1999

3.5.5. Transformações no uso do solo no período 1890 - 1999

3.5.6. Infra-Estrutura versus uso do solo

4. A implantação de infra-estrutura e as transformações no uso do solo: a região de São Miguel Paulista no período 1968 - 1999 - 2001

4.1. A escolha da região de São Miguel Paulista...............................................127

4.2.Características históricas..............................................................................131

4.3.Características gerais da população e ocupação................................................133

4.3.1. População

4.3.2. Ocupação

4.4. Características gerais da infra-estrutura da região.

4.4.1. Coleta de esgotos

4.4.2. Abastecimento de água

4.4.3. Iluminação pública

4.4.4. Energia elétrica

4.4.5. Gás canalizado

4.4.6. Telefonia

4.4.7. Cabo óptico

4.5. Infra-estrutura e uso do solo em São Miguel Paulista

4.5.1. Período 1968-1975

4.5.2. Período $1975-1985$

4.5.3. Diagnóstico 1985

4.5.4. Período 1985 - 1995 - 1999

4.5.5. Transformações no uso do solo no período 1968 - 1999

4.5.6. Situação em 2001

4.5.7. Infra-estrutura versus uso do solo

5. Considerações finais.

.155

5.1. Os fatores de implantação da infra-estrutura

5.2. A relação entre a existência de infra-estrutura e as transformações de uso do solo

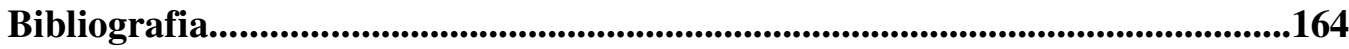

Anexo ..................................................................................................................................................174 


\section{Lista de siglas}

RAE : Repartição de águas e esgotos

DAE : Departamento de águas e esgotos

SABESP: Companhia de saneamento básico do estado de São Paulo

EMAE: Empresa metropolitana de águas e energia

SEMPLA: Secretaria municipal de planejamento

IBGE: Instituto brasileiro de geografia e estatística

PMSP: Prefeitura do município de São Paulo

PRODAM: Processamento de dados do município

ILUME: Departamento de iluminação pública do município

COMGÁS: Companhia de gás

ELETROPAULO: Metropolitana eletricidade de São Paulo

EMBRATEL: Empresa brasileira de telecomunicações

EMPLASA: Empresa metropolitana de planejamento 


\section{Lista de Figuras}

\section{Capítulo2}

Figura 2.1. Esquema de funções das empresas de saneamento básico em 1970 .32

Figura 2.2. Esquema simplificado do abastecimento de água na cidade de SP em 1930 .....35

Figura 2.3. Distribuição territorial da rede de abastecimento de água no MSP 1900 / 00.... 39

Figura 2.4. Mananciais e principais setores de abastecimento do MSP...................................44

Figura 2.5. Esquema simplificado da distribuição de água no MSP.......................................50

Figura 2.6. Distribuição territorial da rede de coleta de esgotos no MSP 1900 / 00...............57

Figura 2.7. Setores abrangidos pelas principais estações de tratamento de esgotos no MSP........60

Figura 2.8. Distribuição territorial da rede de gás canalizado no MSP 1958 / 99...................67

Figura 2.9. Setores administrativos da Eletropaulo no MSP..................................................71

Figura 2.10. Distribuição territorial da rede de iluminação pública no MSP 1900/97...........77

Figura 2.11. Esquema genérico do sistema hidráulico da EMAE ao redor do MSP..............80

Figura 2.12. Distribuição territorial das estações transformadoras de energia no MSP $1980 \ldots \ldots . . . .82$

Figura 2.13.Unidades de controle, centrais telefônicas e área de influência - divisão oeste.........87

Figura 2.14.Unidades de controle, centrais telefônicas e área de influência - divisão leste..........88

Figura 2.15.Distribuição territorial aproximada das centrais telefônicas no MSP 1999 ........89

Figura 2.16. Utilização simultânea dos postes para energia, telefonia e cabo óptico............91

Figura 2.17. Distritos servidos por tv a cabo no MSP 1999 .92

\section{Capítulo 3}

Figura 3.1. Centro expandido segundo Emplasa, 1993 ….....................................................

Figura 3.2.Causas e consequiências do desenvolvimento da região.......................................100

Figura 3.3. Uso do solo no MSP - centro expandido - Período 1890 - 1922 ....................111

Figura 3.4. Infra-estrutura no MSP - centro expandido - Período 1890 - 1922..................112

Figura 3.5. Uso do solo no MSP - centro expandido - Período 1922 - 1952 ......................115

Figura 3.6. Infra-estrutura no MSP - centro expandido - Período 1922 - 1952..................116

Figura 3.7. Uso do solo no MSP - centro expandido - Período 1952 - 1972.....................118

Figura 3.8. Infra-estrutura no MSP - centro expandido - Período 1952 - 1972..................119 
Figura 3.9. Uso do solo no MSP - centro expandido - Período 1972 - 1999.....................121

Figura 3.10. Infra-estrutura no MSP - centro expandido-Período 1972-1999...................122

Figura 3.11. Infra-estrutura no MSP - centro expandido-Período 1972-1999..................123

Figura 3.12. Mapa resumo: infra-estrutura - centro expandido-Período 1890-1999..........126

\section{Capítulo 4}

Figura 4.1. A região de São Miguel Paulista..................................................................128

Figura 4.2. Rede de abastecimento de água na zona leste - 1975-1995............................130

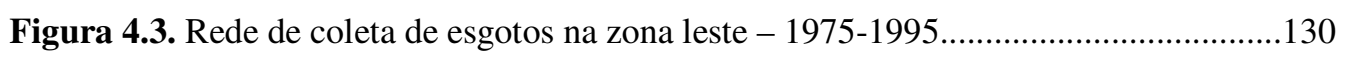

Figura 4.4. Rede de iluminação pública na zona leste - 1975-1995 .................................130

Figura 4.5. Causas e conseqüências das limitações na região …………………………....135

Figura 4.6. Uso do solo no MSP - São Miguel Paulista-Período 1968 - 1999 ..................146

Figura 4.7. Infra-estrutura no MSP - São Miguel Paulista - Período 1968 - 1999 ............147

Figura 4.8. Infra-estrutura no MSP - São Miguel Paulista - Período 1968 - 1999 ............148

Figura 4.9. Diagnóstico 85: infra-estrutura e uso do solo no MSP -São Miguel Paulista .149

Figura 4.10. Localização dos endereços visitados, escolhidos segundo a ausência da rede de coleta esgotos .........150

\section{Capítulo 5}

Figura 5.1. O uso do solo como atrativo para implantação da infra-estrutura 158

Figura 5.2. Importância da infra-estrutura segundo região, período de estudo e uso do solo. $160-161$ 


\section{Lista de Gráficos}

\section{Capítulo 2}

Gráfico 2.1. Extensão da rede de água $(\mathrm{km})$ .37

Gráfico 2.2. Evolução do número de ligações da rede de água. 37

Gráfico 2.3. População atendida pela rede de água versus população total do Município..37

Gráfico 2.4. Captação total dos mananciais (m3/s). 45

Gráfico 2.5.Evolução dos principais mananciais de abastecimento de água da GSP $(\mathrm{m} 3 / \mathrm{s})$ .45

Gráfico 2.6. Evolução da implantação de reservatórios e torres. . .49

Gráfico 2.7. Extensão da rede de esgotos $(\mathrm{km})$..

Gráfico 2.8. Evolução do número de ligações da rede de esgotos .54

Gráfico 2.9. População atendida pela rede de esgotos x população total do Município.........54

Gráfico 2.10. Evolução total do tratamento de esgotos da GSP (m3/s).................................59

Gráfico 2.11. Evolução do volume de esgoto tratado (m3/s)................................................59

Gráfico 2.12. Variação do consumo de gás de nafta por tipo de consumidor (\%)..................65

Gráfico 2.13. Variação do consumo de gás natural por tipo de consumidor (\%)...................66

Gráfico 2.14. Variação consumo de energia elétrica no município / tipo de consumidor $(\%)$ .75

Gráfico 2.15. Evolução do consumo de energia elétrica no MSP (mwh)..............................76

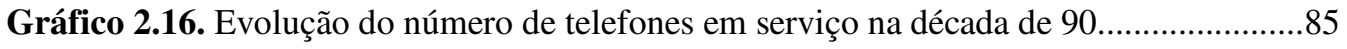

Gráfico 2.17. Evolução do número de telefones por 1000 habitantes no MSP........................86

\section{Capítulo 3}

Gráfico 3.1. Evolução da população na região do centro expandido (em mil hab). . .97

Gráfico 3.2. Porcentagem de ligações a rede geral (esgoto) - centro histórico 1970/91.....101

Gráfico 3.3. Porcentagem de ligações a rede geral (esgoto) - distritos ao redor 1970/91...101

Gráfico 3.4. Porcentagem de ligações a rede geral (água) - centro histórico 1970/91.........103

Gráfico 3.5. Porcentagem de ligações a rede geral (água) - distritos ao redor 1970/9.1.....103

Gráfico 3.6. Iluminação Pública da região do centro Expandido............................................105

Gráfico 3.7. Porcentagem de ligações a rede geral (energia)- c. histórico 1970..................105

Gráfico 3.8. Porcentagem de ligações a rede geral (energia) - distritos ao redor 1970.......105

Gráfico 3.9. Porcentagem consumo de energia/tipo de uso - centro histórico 1985/96.....106

Gráfico 3.10.Porcentagem consumo de energia/tipo de uso - distritos ao redor 1985/96..106

Gráfico 3.11. Porcentagem de consumo de energia/tipo de uso -centro histórico 1985... 107 
Gráfico 3.12. Porcentagem de consumo de energia/tipo de uso -centro histórico 1991.....107

Gráfico 3.13. Porcentagem de consumo de energia/tipo de uso -distritos ao redor 1985...107

Gráfico 3.14. Porcentagem de consumo de energia/tipo de uso -distritos ao redor 1991...107

\section{Capítulo 4}

Gráfico 4.1. Evolução da população na região de São Miguel Paulista (em mil hab)....

Gráfico 4.2. \% de atendimento serviço de coleta de esgotos em S.Miguel Paulista 1970..136

Gráfico 4.3. \% de atendimento serviço de coleta de esgotos em S.Miguel Paulista 1991..136

Gráfico 4.4. \% de atendimento serviço de abastecimento de água em S.Miguel Paulista 19 .........138

Gráfico 4.5. \% de atendimento serviço de abastecimento de água em S.Miguel Paulista $1991 \ldots . . .138$

Gráfico 4.6. Iluminação pública da região de São Miguel Paulista. 138

Gráfico 4.7. Porcentagem de ligações a rede geral (energia)- S. Miguel Paulista 1970.....139

Gráfico 4.8. Porcentagem consumo de energia/tipo de uso - S.Miguel Paulista 1985/91.139

\section{Lista de fotos}

\section{Capítulo 4}

Foto 4.1. Avenida Ascenso Fernandes - ponto final do ônibus Jd. Helena - Pq D. Pedro..151

Foto 4.2. Final da Av. José Maria Lisboa - Jd. São Martinho ..............................................151

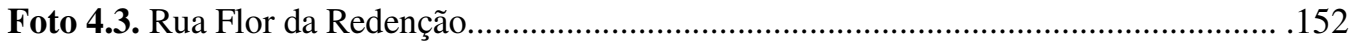

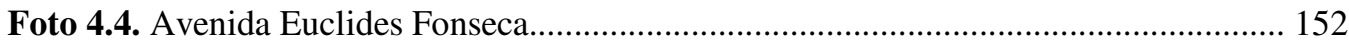

Foto 4.5. Rua Cruzeiro da Fortaleza..............................................................................152

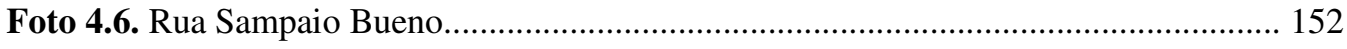

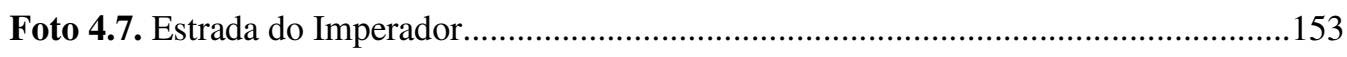

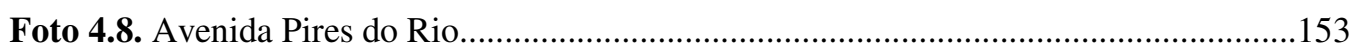

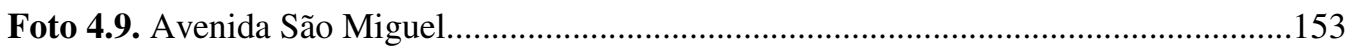

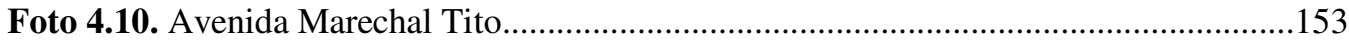




\section{Lista de Tabelas}

\section{Capítulo 2}

Tabela 2.1. Setores de abastecimento e consumo diário em 1927 34

Tabela 2.2. Composição dos gráficos sobre a rede de abastecimento de água 38

Tabela 2.3.Composição dos gráficos sobre produção e distribuição de água para a RMSP .46

Tabela 2.4. Características dos reservatórios e torres no MSP .48

Tabela 2.5. Implantação e capacidade de torres e reservatórios no MSP. .49

Tabela 2.6. Composição dos gráficos sobre a rede de coleta de esgotos .53

Tabela 2.7. Composição dos gráficos sobre tratamento de esgotos. .58

Tabela 2.8. Composição dos gráficos sobre a utilização de gás de nafta no MSP..................66

Tabela 2.9. Composição dos gráficos sobre a utilização de gás natural no MSP....................66

Tabela 2.10. Porcentagem de consumo de energia elétrica no MSP por tipo de uso...............75

Tabela 2.11. Composição dos gráficos sobre a rede de energia elétrica.................................76

Tabela 2.12. Evolução da capacidade das usinas do complexo Light - Emae em uso atualmente. . .79

Tabela 2.13. Evolução do número de telefones em serviço na década de 90 ..........................85

Tabela 2.14. Evolução do número de telefones por 1000 habitantes no MSP .86

\section{Capítulo 3}

Tabela 3.1.Evolução da população no centro expandido

Tabela 3.2. Evolução da renda mensal no centro expandido. .98

Tabela 3.3. Faixas de densidade demográfica segundo os distritos

Tabela 3.4. Quota média de área construída residencial por habitante. 100

Tabela 3.5. Porcentagem de ligações a rede geral (esgotos) - centro histórico 1970/91.....101

Tabela 3.6. Porcentagem de ligações a rede geral (esgotos) - distritos ao redor 1970/91...101

Tabela 3.7. Porcentagem de ligações rede geral (água) - centro histórico 1970/91 103

Tabela 3.8. Porcentagem de ligações a rede geral (água) - distritos ao redor 1970/91......103

Tabela 3.9. Condições de Iluminação Pública 1970/1991 - centro expandido .104

Tabela 3.10. Porcentagem de ligações a rede geral (energia) - centro expandido 1970......105

Tabela 3.11. Porcentagem consumo de energia/tipo de uso - centro histórico 1985/96.....106 Tabela 3.12. Porcentagem consumo de energia/tipo de uso - distritos ao redor 1985/96....106 
Tabela 3.13. Porcentagem consumo de energia/tipo de uso - centro histórico 1985..........107

Tabela 3.14. Porcentagem consumo de energia/tipo de uso - centro histórico 1991...........107

Tabela 3.15. Porcentagem consumo de energia/tipo de uso - distritos ao redor 1985........107

Tabela 3.16. Porcentagem consumo de energia/tipo de uso - distritos ao redor 1991........107

\section{Capítulo 4}

Tabela 4.1. Evolução da renda mensal na região de São Miguel Paulista.............................134

Tabela 4.2. Faixas de densidade demográfica segundo os distritos.......................................134

Tabela 4.3. Quota média de área construída residencial por habitante.................................135

Tabela 4.4. Condições sanitárias rede de coleta de esgotos - S.Miguel Paulista 1970/91...137

Tabela 4.5. Condições sanitárias rede de abast. Água - S.Miguel Paulista 1970/1991 .......138

Tabela 4.6. Iluminação pública 1970/1991 - Região de São Miguel Paulista......................139

Tabela 4.7. Consumo de energia elétrica/tipo de uso 1970/91 - Região São Miguel Paulista..139 


\section{Introdução}

$\underline{\text { Infra-estrutura, desenvolvimento econômico e social }}$

O pleno desenvolvimento das cidades está diretamente relacionado com as redes de infra-estrutura. Através de sua existência, melhoram-se as condições ambientais e de produção e conseqüentemente, a qualidade de vida ${ }^{1}$ da população. Segundo ZMITROWICZ; ANGELIS NETO (1997, p.22): “a qualidade de espaço urbano se prende a um conjunto complexo de fatores ligados não apenas à tipologia da construção como ao meio ambiente interno e externo, apoiados em equipamentos sociais e urbanos próximos e nas redes de infra-estrutura e serviços correspondentes".

No caso do saneamento, é evidente que a implantação de redes de abastecimento de água e coleta de esgotos é imprescindível.

A demanda por água pode ser estipulada pela necessidade de saúde, insumo de produção ou bem de consumo (NUCCI, 1983, p.24), assim como a coleta de esgotos funcionando como um agente de qualidade ambiental.

O uso de energia elétrica e gás canalizado, além de favorecer aspectos de comodidade e segurança, é a base de apoio a produção, alimentando indústrias e o comércio, conforme enfatiza MASCARÓ (1987, p.29): “as redes de gás e eletricidade permitem que as cidades mudem de função e passem de centros administrativos ou de intercâmbio a centros de produção".

A expansão da rede de telefonia fixa e móvel e dos telefones públicos capazes de receber chamadas, diminuiu a distância entre as pessoas, possibilitando até aos menos favorecidos, a sensação de estar incluídos no processo de desenvolvimento tecnológico.

\footnotetext{
${ }^{1}$ MENEZES (1984, p.17), define qualidade de vida como: "uma noção associada a meio, a ambiente, no sentido de ser resultado dos fatores e condições que pressionam e interagem com a comunidade. Conforme a ótica de sua observação, a qualidade de vida também se chama nível de vida, em termos econômicos; condições de vida em termos sociais e condições ambientais, em termos ecológicos. A qualidade de vida resulta das condições de alimentação, abastecimento d'água, de moradia, de transportes, de destinação dos esgotos e do lixo, de emprego, de renda, de escola, de seguridade, de qualidade do ar, do lazer, da higiene, etc.. é na realidade, uma noção, um conceito, que se ajusta ao equilíbrio dinâmico dos ecossistemas".
} 
O sistema de cabos ópticos, base do funcionamento das tv's a cabo e da internet vem assumindo importante papel na inserção do país em negócios com o Mundo e traz aos que podem usufruir de seus serviços, mais informação e cultura. Esse sistema também propicia a substituição dos cabos convencionais para ligações de energia elétrica e telefonia, diminuindo o diâmetro e número de cabos utilizados para a expansão dessas redes.

TOLEDO SILVA (1991, p.21) também enfatiza a relação entre infra-estrutura e desenvolvimento: "A infra-estrutura e os serviços urbanos constituem condição e manifestação de desenvolvimento econômico, predominantemente localizado nas cidades a partir dos ciclos de industrialização que demarcaram a primazia dos setores secundário e terciário na formação da riqueza ... cumprem essencialmente duas funções no desenvolvimento urbano. A primeira vincula-se a criação de condições necessárias a produção ... e a segunda, as condições de consumo."

$\mathrm{O}$ esquema abaixo demonstra a função das redes para a população e para a cidade como um todo. ${ }^{2}$

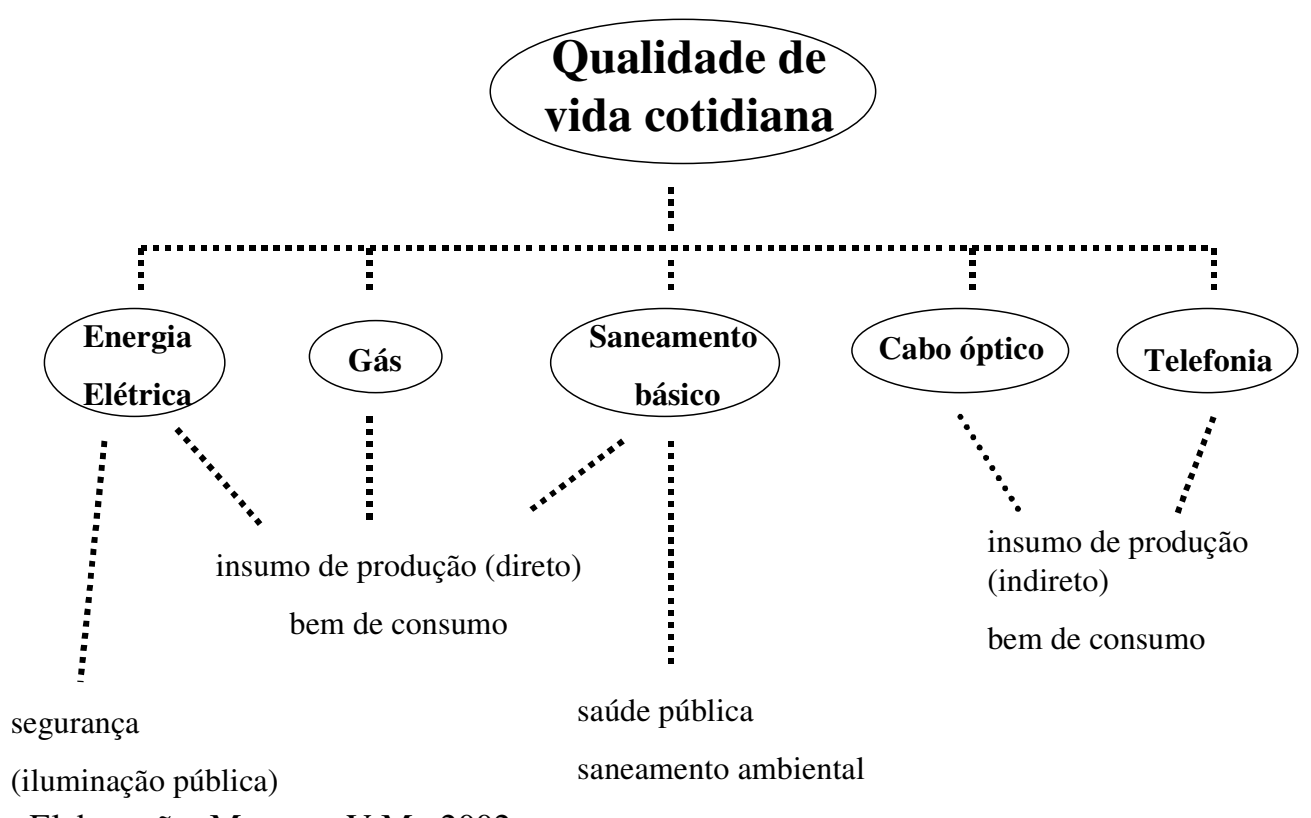

Elaboração: Massara, V.M., 2002.

Considerando a importância das infra-estruturas no desenvolvimento sócioeconômico e no planejamento de uma região, propomos os objetivos a seguir.

\footnotetext{
${ }^{2}$ Os serviços elencados acima são necessários com frequiência cotidiana, em contraste com a rede de drenagem pluvial que embora imprescindível, é de uso esporádico. Esta foi uma das razões da escolha dessas redes para a nossa pesquisa.
} 


\section{Objetivos}

O objetivo geral desta dissertação é a apresentação do processo de implantação dos sistemas de infra-estrutura existentes em São Paulo verificando a seguir a sua relação com as transformações de uso do solo. Os sistemas de infraestrutura considerados foram: saneamento, energia e comunicações. A análise de sua evolução físico-temporal, por meio da história ao longo do século XX seguiu o desenvolvimento urbano com dados numéricos e mapas, visando também a criação de um cd-rom para consulta e impressão das informações gráficas.

Como objetivo específico, pretendemos relacionar a evolução do uso do solo com a existência das redes de infra-estrutura, através da comparação de duas áreas distintas da cidade, com a intenção de colaborar em estudos futuros que dêem continuidade a esta pesquisa, visando iniciar um levantamento sobre a importância da infra-estrutura e do uso do solo na qualidade de vida e na valorização imobiliária de diferentes regiões da cidade.

A médio prazo, foi intenção do trabalho:

No âmbito técnico:

- Contribuir para o detalhamento da análise quanto a existência das redes e sua real condição de uso, através de dados numéricos sobre a capacidade dos serviços por região visando o estudo de potencial de adensamento;

No âmbito social e do meio ambiente:

- Incentivar trabalhos com estudos minuciosos de comparação entre áreas distintas e sua qualidade de vida.

No âmbito do conhecimento geral:

- Propiciar a qualquer pessoa - ligada ou não as questões urbanas - uma idéia de como se deu a expansão dos serviços de infra-estrutura, por meio de imediata visualização das "manchas” de implantação das redes ao longo do século XX. 


\section{Aspectos metodológicos}

Partindo da premissa que "existe relação entre a presença de infra-estrutura e os usos do solo", seguimos a verificação da importância dessa relação para o desenvolvimento de uma região com base na apresentação gráfica da evolução dos sistemas de infra-estrutura e em paralelo das transformações no uso do solo, considerando que o método fenomenológico é o que mais se aproxima de nossa intenção.

Segundo VARGAS (1985), este método pretende visualizar a essência do fenômeno através de sua descrição dos fatos passados, baseada em coleta e seleção de documentos históricos, seguida sempre de uma tentativa de interpretação do que se passou; às vezes como explicação mas, sempre, como compreensão.

Desta maneira, partindo de um enunciado tido como evidente por si mesmo, combinamos informações para chegar a uma conclusão que implicitamente, já está contida na premissa, buscando dados que sirvam como base para nossa argumentação através de pesquisa dividida em setores de concentração:

\section{Esquema da organização da pesquisa e elaboração da dissertação}

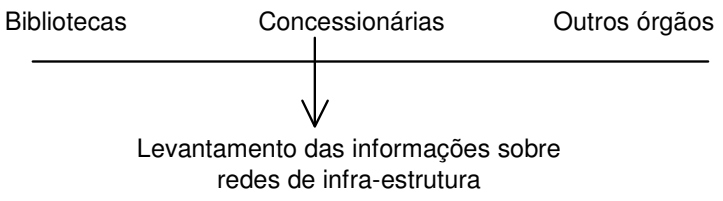

Classificação cronológica dos dados por tipo de infra-estrutura

Análise da coerência entre dados de um mesmo período fornecidos por diferentes órgãos

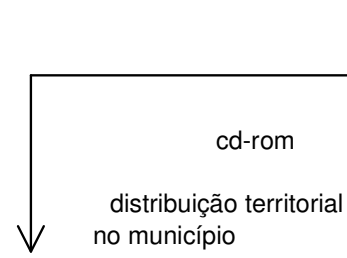

Mapas no municipio

distribuição territorial no centro expandido

distribuição territorial São Miguel Paulista

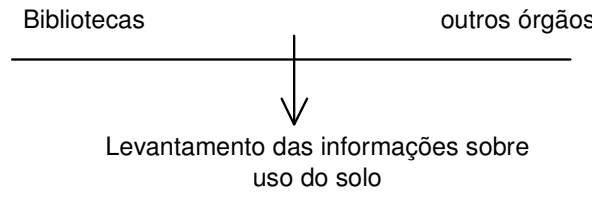

Compatibilização dos dados com as informações sobre infra-estrutura

Verificação da ordem cronológica de criação dos bairros e implantação das redes
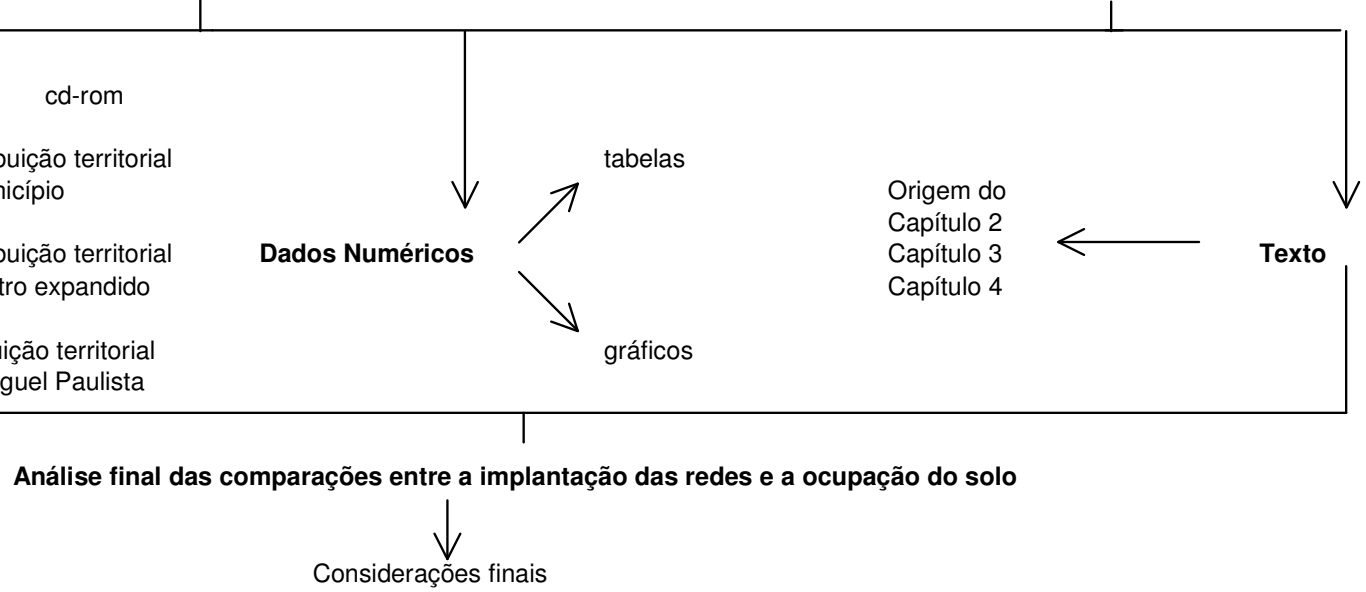


\section{Limitações espaciais $^{3}$}

Quando propomos um estudo sobre infra-estrutura, existem vários rumos que podemos seguir visando focalizar aspectos técnicos, legislação, tarifas, qualidade ambiental, entre outros. No presente caso, foi discutida a correlação no tempo, entre o desenvolvimento urbano, oriundo da implantação de infra-estrutura e das transformações no uso do solo para duas regiões da cidade de São Paulo de diferentes características.

A pesquisa se inicia com uma visão geral da implantação de serviços urbanos no campo do saneamento, energia e comunicações para o Município como um todo. $\mathrm{Na}$ segunda fase proposta, optamos por limitar a área de estudo, visando obter conclusões mais específicas sobre nossa pesquisa mostrando contrastes entre regiões mais centrais e periféricas. Assim selecionamos duas regiões da cidade representando situações opostas de existência das redes: o centro expandido ${ }^{4}$ e a região de São Miguel Paulista.

Área 1:

Centro Expandido

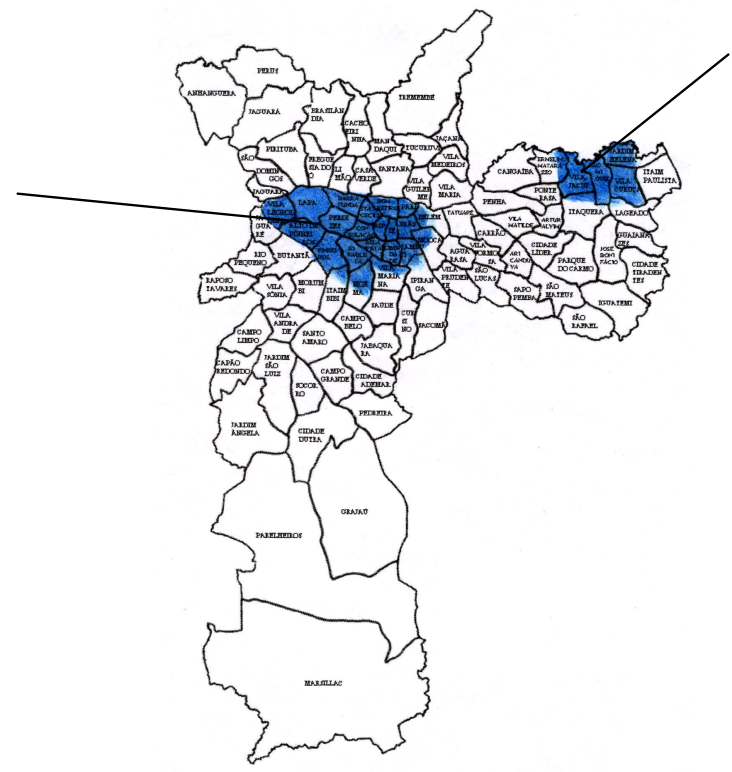

Área 2: Região de São Miguel Paulista

Localização no Município de São Paulo das áreas escolhidas para a segunda parte da pesquisa Fonte: Sempla, 2000.

\footnotetext{
${ }^{3}$ Detalhes sobre as limitações espaciais e temporais de cada região estão nos Capítulos 3 e 4 itens 3.1 e 4.1 .

${ }^{4}$ Para o centro expandido foram aproveitadas informações já existentes sobre uso do solo. Vide BARBOSA, Eunice. Evolução do uso residencial na área central do Município de São Paulo. São Paulo, Dissertação (mestrado), Escola Politécnica da Universidade de São Paulo, 2001.
} 


\section{Estruturação da dissertação}

A fim de atingir os objetivos anteriormente colocados, nossa dissertação de mestrado foi estruturada com base em cinco capítulos, cujos aspectos fundamentais são descritos a seguir.

\section{Infra-estrutura e Uso do solo - Aspectos conceituais}

Com a intenção de apresentar a fundamentação teórica que embasa esta dissertação conceituamos as 'palavras-chave' e o relacionamento entre elas.

Para infra-estrutura, mencionamos bibliografia que enfatiza a importância das redes para o desenvolvimento social e econômico na história das cidades, seguindo com o levantamento dos relatórios técnicos específicos para o Município. No campo do uso do solo, destacamos os estudos sobre organização das cidades, partindo dos modelos téoricos do século XIX até as mudanças oriundas pelo processo de desindustrialização e globalização das cidades.

Entre as linhas de pesquisa relacionando ambos, destacamos os estudos que enfatizam a valorização imobiliária, a localização e a segregação urbana, como conseqüência da implantação de serviços e também o conceito de potencial de adensamento de uma área em função da capacidade disponível das redes.

\section{Breve histórico sobre a evolução dos sistemas ${ }^{5}$ de infra-estrutura do Município de São Paulo}

Através de narrativa sucinta sobre a origem e expansão dos serviços de infraestrutura na cidade durante o século XX, tendo como base gráficos e layers (mapas em camadas), associamos datas ao incremento na capacidade das redes e em sua distribuição territorial, para as redes de abastecimento de água, coleta de esgotos, energia elétrica, gás, telefonia e cabo óptico.

5 Optamos por enfatizar a evolução da distribuição territorial das infra-estruturas. A descrição dos subsistemas dentro de cada rede é abordada de forma sucinta. 


\section{A implantação de infra-estrutura e as transformações no uso do solo: o centro expandido no período 1890-1999}

Objetivando associar as mudanças e incrementos na ocupação da região a existência das redes, este capítulo mostra a evolução da infra-estrutura em quatro períodos de transformações de uso do solo, caracterizando o desenvolvimento da área no período 1890-1999.

\section{A implantação de infra-estrutura e as transformações no uso do solo: a região de São Miguel Paulista no período 1968 - 1999 - 2001}

Com o mesmo intuito do capítulo anterior, selecionamos uma área periférica de histórico de expansão populacional e de infra-estrutura tardio, concentrando a verificação da relação entre uso do solo e existência das redes, no período de intensificação de ocupação 1968-1999, arrematando a conclusão sobre a condição dos serviços, através de pesquisa de campo em 2001.

\section{Considerações finais}

Usando as informações obtidas nos capítulos 3 e 4, sobre duas regiões distintas e sua relação com a existência das redes e evolução dos serviços, comentamos qual a relação entre uso do solo e infra-estrutura e indicamos outras variáveis de importância para determinação da implantação das redes.

\section{Anexo}

O anexo explica a elaboração das figuras em forma de camadas (layers), mostrando a evolução da distribuição territorial das redes e o funcionamento do cdrom para impressão desses esquemas. 


\title{
Capítulo 1. Infra-estrutura e Uso do Solo - Aspectos Conceituais
}

\author{
"O desenvolvimento da infra-estrutura e dos \\ equipamentos (rede de água, esgotos, energia \\ elétrica, gás, telefone, pavimentação, \\ iluminação pública), pode criar possibilidades \\ de adensamento de usos existentes e condições \\ ambientais propícias à implantação de novas \\ categorias de uso”. \\ (ZMITROWICZ, 1979, p.51.)
}

\subsection{Infra-Estrutura, serviços e equipamentos públicos}

Conceitualmente, consideramos conveniente diferenciar infra-estrutura, equipamentos urbanos e serviços públicos urbanos.

De maneira sucinta, a coletânea intitulada: Vocabulário Básico do Meio Ambiente (1991, p. 90;116;184), traz as seguintes definições:

- Infra-estrutura (urbana): "conjunto de obras que constituem os suportes do funcionamento das cidades e que possibilitam o uso urbano do solo, isto é, o conjunto de redes básicas de condução e distribuição: rede viária, água potável, redes de esgotamento, energia elétrica, gás, telefone, entre outras, que viabilizam a mobilidade das pessoas, o abastecimento e a descarga, a dotação de combustíveis básicos, a condução das águas, a drenagem e a retirada dos despejos urbanos";

- Equipamento urbano: “conjunto de edificações e espaços, predominantemente de uso público, nos quais se realizam atividades complementares à habitação e ao trabalho, ou nos quais se oferecem à população os serviços de bem-estar social e de apoio às atividades econômicas" ;

- Serviço público: "atividade administrativa pela qual a Administração, por si ou por seus delegados, satisfaz as necessidades essenciais ou secundárias da comunidade, assim por lei consideradas e sob as condições por aquela impostas unilateralmente". 
A seguir, apresentamos a visão de alguns autores, semelhante em termos gerais, salvo ênfase devido ao campo de estudo de cada trabalho.

Segundo GARCIAS (1991, p.7 ), "a inclusão do termo "serviços” se deve ao fato de a literatura sobre o assunto classificar como infra-estrutura urbana os seguintes serviços: abastecimento de água, esgotos, drenagem urbana, energia, comunicações, transporte, etc., e unicamente como serviços: coleta de lixo, segurança pública, combate a incêndios, assistência social, etc."

O mesmo autor comenta ainda a classificação sob o enfoque do direito urbanístico feita em Projeto de Lei de 1989, definindo como equipamento urbano:

Os bens destinados à prestação dos serviços de abastecimento de água, esgotamento sanitário e pluvial, limpeza pública, energia elétrica, telecomunicações, serviço postal, transporte e sistema viário, gás canalizado, segurança pública e outros.

A conceituação apresentada por ABIKO (1995, p.4), acrescenta de forma clara a função dos "serviços" e "equipamentos" como suportes administrativo e físico das redes: "A infra-estrutura compreende a rede física propriamente dita...já o serviço corresponde a gestão, a operação, a tarifação e a manutenção da rede...os equipamentos urbanos são os edifícios e as instalações, necessários à gestão dos serviços".

A tese elaborada por MIGLIORINI (1997, p.33), apresenta similar visão: “consideramos como equipamentos urbanos, os espaços edificáveis ou não, destinados ao atendimento pelo poder público, das necessidades básicas do cidadão sejam educação, lazer...já como redes de infra-estrutura e serviços urbanos, entendemos todo o sistema de canais, aparentes ou não, que permitem a distribuição dos recursos naturais, bens e fontes de energia necessários à sobrevivência do homem no meio urbano, a coleta e o tratamento de detritos por ele produzidos, bem como sua circulação e comunicação com seus semelhantes".

\subsection{O desenvolvimento das cidades tendo como base a evolução da infra- estrutura, a ordenação e transformações no uso do solo}

\section{$\underline{\text { A infra-estrutura }}$}


MUMFORD (1938, p.437), mostra em uma visão histórica, como as redes de infra-estrutura ganharam importância no desenvolvimento das cidades, mencionando as questões de higiene no século XIX e a consequente implantação de sistemas de abastecimento de água e deposição de esgotos para suprir essa necessidade: “A higiene acentuava a importância do fornecimento de água exigindo não simplesmente a pureza, mas aumentando continuadamente a quantidade necessária, à medida que os hábitos de banho e lavagem propagavam-se em ondas concêntricas de um a outro grupo econômico. Tais fatos mostram-se igualmente verdadeiros quanto aos sistemas de deposição de sobras e esgotos." Comenta ainda as possibilidades criadas pelo uso da energia elétrica como parte do incentivo para a Revolução Industrial e da introdução do telefone: "Com novos meios de transporte e de geração de energia, vantagens locais, outrora concentradas num centro circunscrito, num único ponto, podem ser distribuídas através de toda uma região. Para completar tudo isso, o telégrafo, o telefone, o rádio, já igualmente surgiam no complexo neotécnico". $\mathrm{O}$ autor conclui o raciocínio, com as modificações na cidade oriundas dessa evolução: "O efeito de todos esses instrumentos é o de aumentar a esfera de atividades ao mesmo tempo em que diminuem a necessidade de movimento físico, originando densa colonização e criando novos centros". Ainda sobre a expansão da cidade e as possibilidades criadas pela energia elétrica, mencionando o geógrafo Piotr Kropotkin, enfatiza em obra de 1961 (p. 555) : “Quase meio século à frente da opinião econômica e técnica de seu tempo, havia ele aprendido o fato de que a flexibilidade e adaptabilidade da comunicação elétrica e da energia elétrica, juntamente com as possibilidades de cultivo intensivo e biodinâmico da terra, tinham lançado as bases de um desenvolvimento urbano mais descentralizado..."

Também sobre a geração de energia, COTTRELL (1955, p.108), trata da relação entre energia, mudanças sociais, desenvolvimento econômico e tecnológico, de forma a incrementar a produção de indústrias, a iluminação de vias públicas e através das estações transformadoras facilitando e "tornando mais barato o alcance de maiores distâncias, propiciando a ocupação de áreas vazias, além de melhorar a condição de áreas já consolidadas”.

MASCARÓ (1987, p.17), enfatiza a relação entre a cidade e o conjunto de elementos, (serviços e equipamentos) que propiciam seu pleno desenvolvimento: “do 
espaço urbano também fazem parte as redes de infra-estrutura que possibilita seu uso e, de acordo com sua concepção, se transformam em elemento de associação entre a forma, a função e a estrutura, ou contribuem para que o conjunto urbano se apresente como fragmentos de um catálogo incoerente de elementos que não estão articulados entre si”.

MORETTI (1993, p.134), apresenta a definição dos serviços de infraestrutura a serem exigidos dos novos empreendimentos habitacionais e sua variação conforme o município, levando em conta os condicionantes econômicos do local, enfatizando a importância da existência (entre outros) de :

- Abastecimento de água potável;

- Captação, condução, tratamento e disposição de esgotos.

- Fornecimento de energia elétrica;

- Iluminação de vias públicas;

- Rede de telefonia;

- Fornecimento de gás canalizado ${ }^{6}$.

ZMITROWICZ E ANGELIS NETO (1997, p.2), definem as redes segundo sua função na cidade: "A infra-estrutura urbana pode ser conceituada como um sistema técnico de equipamentos e serviços necessários ao desenvolvimento das funções urbanas, podendo estas funções ser vistas sob aspectos social, econômico e institucional. Sob o aspecto social, a infra-estrutura urbana visa promover adequadas condições de moradia, trabalho, saúde, educação, lazer e segurança. No que se refere ao aspecto econômico, a infra-estrutura urbana deve propiciar o desenvolvimento das atividades produtivas, isto é a produção e comercialização de bens e serviços. E sob o aspecto institucional, entende-se que a infra-estrutura urbana deva propiciar os meios necessários ao desenvolvimento das atividades político-administrativas, entre os quais se inclui a gerência da própria cidade" .

Em trabalho sobre Estruturação Territorial Urbana, ZMITROWICZ (1997, p.13), resume o conceito: "Os conjuntos de redes de infra-estruturas ligam os espaços urbanos às fontes de matéria, energia e informações, ou aos locais de disposição de

\footnotetext{
${ }^{6}$ Estes tópicos mais a rede de cabo óptico, compõe o que denominamos: "O perfil da infra-
} estrutura no Município de São Paulo" e que apresentaremos nos próximos capítulos. 
matérias nocivas ou prejudiciais, interconectando as zonas urbanas com as zonas de seu entorno..."

Ainda no mesmo trabalho, conclui ZMITROWICZ (1997, pg. 35): “considerando as "infra-estruturas" - energia, saneamento e comunicação como "fluxos" que conectam os locais em que se processa a 'produção' aos ambientes onde se processo o 'consumo', sua perfeita adequação no espaço, além de melhorar a qualidade de vida, favorece o crescimento da economia e o desenvolvimento integrado de todas as funções da cidade."

Sobre a introdução das redes de cabo óptico, GIOZZA (1991) e NOBRE (2000), argumentam sobre a consequente otimização do setor de prestação de serviços e as mudanças no projeto de escritórios: espaços cada vez menores se opondo às necessidades das décadas anteriores e à característica dos edifícios do Centro Histórico de São Paulo.

Com base nos estudos mencionados, buscamos um respaldo de informações no âmbito técnico sobre a evolução das redes de infra-estrutura no Município de São Paulo. Considerando o enfoque histórico sobre sua expansão, os trabalhos de MOTTA (1911), NOVAES (1927), ANDRADE (1966), catálogos da SABESP (1976), TELLES (1984) e os artigos da REVISTA D.A.E. (1936 - 1995), sobre os planos para a evolução do abastecimento de água e coleta de esgotos no Município, forneceram material importante para caracterizar o incremento e os déficits dos sistemas.

No campo da energia elétrica, a descrição histórica de SOUZA (1950), BRANCO (1951), coletâneas da Eletropaulo (1989; 1990), relatórios da Cesp (1997) e consulta ao EMAE (2001), cobrem a análise histórica durante o século XX. Para a rede de gás, o relatório da COMGÁS (1997) e catálogos do seu acervo histórico (1997), propiciaram a obtenção de informações sobre a iluminação a gás e o uso do gás para aquecimento.

No campo das comunicações, LEÃO (1941), traz dados referentes as centrais telefônicas e densidade de aparelhos do início do século até 1940, informações completadas no catálogo do MUSEU DO TELEFONE (1977) e pelo contato com a TELEFONICA, que forneceu planilhas com dados de 1998/2000. No levantamento 
sobre cabos ópticos, GIOZZA (1991), MESQUITA (1998) e NOBRE (2000), explicam a utilidade e expansão das redes.

Os relatórios Públicos e de Órgãos não Governamentais ligados às questões urbanas, forneceram as informações gráficas (mapas e esquemas) e os dados quantitativos da capacidade das redes.

O relatório da Associação Nacional dos Geógrafos, organizado por AZEVEDO (1958, 4 vol.), apresenta várias informações tanto sobre infra-estrutura como sobre o perfil sócio-econômico da população do início do século a década de 50. O PUB - Plano Urbanístico Básico (1968), através dos volumes 2: Serviços Urbanos e 5: Infra-Estrutura, traça o perfil das redes através de mapas e dados quantitativos que foram combinados as informações sobre uso do solo e questões de expansão da cidade.

Os relatórios da Prefeitura de 1958 e 1975 (16 vol.), descrevem a condição das redes e possibilitaram a montagem dos primeiros mapas "rua a rua". O mapa de uso do solo de 1958, embora de baixa qualidade gráfica, serviu como um parâmetro para conclusões sobre as transformações da época.

Os Sumários de Dados (1977/1998) produzidos pela EMPLASA, fornecem dados no campo do saneamento e da energia elétrica, que após serem reunidos, foram transformados em tabelas que ajudam na caracterização da expansão dos serviços a partir da década de 70 .

Trabalhos da SEMPLA: Diagnóstico regionalizado do Município de São Paulo (1983) e Plano para cinco regiões administrativas do Município de São Paulo (1986), detalham a situação por região da cidade. O primeiro fornece importantes considerações para as redes de iluminação pública e gás canalizado. O segundo, propiciou a criação de uma período intermediário (1985) nos estudos de uso do solo e infra-estrutura para a região de São Miguel Paulista. Também o Plano do Município de São Paulo 1985/2000 (1985) colaborou com dados para a década de 80, principalmente para o saneamento, fornecendo tabelas com a captação dos mananciais da época e iluminação pública, com informações detalhadas sobre o salto na implantação desse serviço, verificado na primeira metade da década de 80 . Os cadernos: Evolução do Uso do Solo nos anos 90 e Perfil Socioeconômico do 
Município de São Paulo (2000/01), também produzidos pela SEMPLA, detalham as alterações no uso do solo, resumindo informações a partir de 1980 e fornecem características da população úteis para o perfil da década de 90.

Para a elaboração dos capítulos sobre as regiões do centro e de São Miguel, os censos do IBGE de 1970, 1991 e 2000 foram de suma importância no tocante a descrição da condição das redes de abastecimento de água, coleta de esgotos e consumo de energia elétrica por tipo de uso, fornecendo valores para cada distrito. Devemos ressaltar, que a única dificuldade na utilização desses dados consiste na falta de concordância entre os perímetros utilizados por esse órgão e também pela Eletropaulo e aqueles utilizados pela Prefeitura, Sempla e Sabesp (baseados na Lei de 1991 e na divisão em administrações regionais vigente até 2000).

Cabe explicar, que no Capítulo 3 quando descrevemos a condição das redes e evolução da população e renda mensal, dividimos a área denominada neste trabalho como "Centro Expandido" em dois grupos: "distritos do centro histórico" e "distritos ao redor", com a intenção de uniformizar os dados com os perímetros e denominações de todos os órgãos envolvidos nesta pesquisa. Desta forma definimos como centro expandido (vide figura 3.1, pg.94), a soma dos distritos descritos no grupo "centro histórico" e no grupo "distritos ao redor".

\section{A ordenação e transformações no uso do solo}

A visão do desenvolvimento urbano e sua ordenação no espaço pode levar em conta muitos aspectos, como a densidade demográfica, o status social, a qualidade ambiental, os fatores de valorização imobiliária, as questões de localização e acessibilidade, a presença de redes de infra-estrutura e as leis que regem todos esses fatores e organizam a ocupação de uma região.

A partir dos estudos de VON THUNEN (1842), sobre localização ideal de culturas agrícolas, vários autores abordam a expansão da cidade e sua organização.

No decorrer do século XIX, surgiram os distritos industriais, com a intenção de sanear o problema habitacional. Essas "cidades-modelo" exerceram grande influência no desenvolvimento do Planejamento Urbano. 
HOWARD (1898) e os modelos utópicos das cidades-jardim, posiciona-se contra a insalubridade das grandes cidades industriais, visando descentralizar o desenvolvimento da cidade e equilibrar a migração campo-centro urbano. GARNIER (1901), idealiza a cite industrielle (cidade industrial), onde a organização espacial é estruturada essencialmente em função da indústria.

UNWIN (1901;1913) e PARKER ${ }^{7}$ (1901), argumentam sobre uma adaptação das cidades-jardim, aliando o desenvolvimento urbano as questões ambientais criando bairros ou subúrbios.

HURD (1903) e HAIG (1926), focalizam a localização e acessibilidade como principal fator na atração de usos e conseqüente valorização dos terrenos.

BURGESS (1923), apresentou o modelo de desenvolvimento da cidade em faixas concêntricas. Em 1939, HOYT, se opondo a esse modelo, elaborou uma estrutura usando como fator de expansão urbana a direção ao invés da distância. HARRIS e ULLMANN (1945) propõe a estrutura da cidade baseada em vários centros. Após a segunda guerra, os estudos utilizando o modelo zonal ou teoria do anel concêntrico (baseado na Escola de Chicago), tentam minimizar a distribuição de usos vinculada a variabilidade social, considerando aspectos políticos, sociais e econômicos no desenvolvimento das cidades, como FIREY (1947) levando em conta fatores culturais na organização dos usos do solo, DOUGLASS; CHAUNCY HARRIS e BERGER (1960), mostrando a expansão do subúrbio norte-americano, baseado no advento do automóvel e no desenvolvimento do sistema viário, propiciando que famílias da classe média se deslocassem para áreas mais distantes do centro.

ALONSO e MUTH (1960), voltados ao urbanismo com enfoque econômico, também estudam o contraste entre a pobreza e decadência das áreas centrais e a ascensão dos subúrbios. ALONSO (1964), conclui que a escolha do local para implementação de certo tipo de uso depende, nas atividades econômicas das possibilidades de maximização de seu lucro e nas localizações residências, da máxima satisfação dos moradores e também do custo de transporte (SÓCRATES, 1983, p.27-30).

\footnotetext{
${ }^{7}$ Arquiteto britânico idealizador do plano para o Jardim América em São Paulo.
} 
Em trabalho de 1965, o mesmo autor cria o "Paradoxo de Alonso", ao contrariar vários autores, afirmando que nem sempre a classe mais abastada ocupa os terrenos mais caros (VILLAÇA, 1998, p.146).

Outros estudiosos como WARNER (1962; 1972) e WARD (1968), analisam os subúrbios e sua ocupação, focalizando os imigrantes e a classe mais pobre no núcleo da cidade tendo como base o mapa apresentado por HOYT (1939), que ignora a região periférica de Chicago nos anos 20, comparando-o com o esquema elaborado por BURGESS e NEWCOMB (1931), detalhando a área industrial e a localização das habitações dos operários.

FORM (1970) focaliza a ocupação do solo através de estudos sobre o poder econômico e político do mercado de terras; BERRY (1970) focaliza o status social como elemento de segregação, determinante na localização espacial dos indivíduos, bem como HARVEY (1975), através do estudo comparativo entre o sistema urbano de cidades dos Estados Unidos e Inglaterra e a distribuição de renda da população, mostrando a "renda real das famílias" como preponderante para acesso às oportunidades e melhores localizações.

RICHARDSON (1975), analisa os custos de transporte e o valor dos aluguéis, considerando a acessibilidade como principal componente na competição entre atividades (SÓCRATES, 1983, pg, 27).

GOLDFIELD e BROWNELL (1979), enfatizam que áreas mais antigas e sem renovação acabam por concentrar a população mais pobre, ao mesmo tempo que seu declínio não atrai investimentos.

CAIRNCROSS (1992) e GRAZIA (1993) abordam a vida nas cidades, sob a ótica da qualidade ambiental e do impacto da poluição e da falta de saneamento; também focalizam a necessidade de se buscar outras fontes de recursos para a energia e conter o desperdício na utilização de recursos naturais.

HARVEY (1996, p. 174), enfatiza as mudanças nas cidades oriundas do processo de desindustrialização gerado pela globalização: "a cidade industrial, que funcionava tão bem quanto as oficinas do capitalismo do século XIX e do início do século XX, tornou-se, certamente coisa do passado". 
Também considerando o processo de globalização, NIJMAN (2000) compara o processo de industrialização de várias cidades norte-americanas, tendo como base as facilidades oriundas do avanço da tecnologia de transportes e telecomunicações e comenta o urbanismo sob a ótica da Escola de Los Angeles e sua complexa análise da urbanização do ponto de vista do capitalismo e do surgimento das "cidades globais".

No âmbito nacional e especificamente para o Município de São Paulo, ANDRADE (1966), mostra através das leis de zoneamento, o histórico de expansão e organização da cidade, enfatizando a evolução do sistema viário e da infra-estrutura e seu reflexo no desenvolvimento dos bairros.

MORSE (1970), apresenta o histórico de desenvolvimento da cidade e o que determinou a formação de bairros operários, da área de elite e dos centros comerciais, tendo como respaldo o modelo de Hoyt, bem como LAGENBUCH (1971), introduzindo vários dados numéricos sobre sua evolução, usando como respaldo o modelo de Harris e Ullmann, baseado no estudo dos vários núcleos suburbanos.

Considerando a localização como ponto marcante no desempenho do uso do solo VILLAÇA (1978), apresenta trabalho sobre as grandes cidades do país e sua evolução.

O estudo de ZMITROWICZ (1979), analisa o zoneamento do Município de São Paulo e aspectos de sua implantação na determinação da localização dos diferentes usos; relaciona os fatores que atraem ou repelem certos usos e detalha a função das redes de infra-estrutura como fator de atração, dependendo do tipo de ocupação.

CORDEIRO (1980, p.59), mostra uma complexa metodologia para a determinação do centro de São Paulo e através da relação entre valor imobiliário, ocupação funcional, densidade demográfica e área construída traça o perfil do uso do solo na área central enfatizando que "o poder de atração do centro aumenta pela falta de investimentos em infra-estrutura e equipamentos em outras áreas".

A dissertação de SÓCRATES (1983), propõe um modelo para o uso do solo em São Paulo na década de 70, tendo como base a análise dos modelos teóricos , 
relacionando a importância dos fatores econômicos, políticos, culturais e sociais na estrutura urbana.

Em 1984, a tese de ZMITROWICZ, faz um histórico sobre a implantação das grandes obras no sistema energético, no abastecimento de água e enfatiza o desenvolvimento do sistema viário como principal componente do desenvolvimento do Município de São Paulo.

Os trabalhos de BRUNA (1975, 1978 e 1982), detalham o uso comercial na Grande São Paulo e o desenvolvimento do setor terciário, envolvendo aspectos de valorização das áreas comerciais, do uso de energia para esse fim e da implantação dos shopping centers como novos centros de comércio. O estudo de 1984 se detêm no enfoque das transformações no uso residencial na cidade de São Paulo. Seguindo a mesma linha de pesquisa, VARGAS (1993) trata das transformações no uso comercial baseadas na expansão dos shopping até o início da década de 90 e na verificação que nem sempre a localização é preponderante para a escolha do ponto, enfatizando que estratégias de negócios bem formuladas tornam qualquer lugar atrativo.

SOMEKH (1994), aborda o processo de verticalização de São Paulo, decorrente da industrialização (em particular da construção civil) e da necessidade de escritórios centrais como sedes dessas indústrias; das novas leis de zoneamento e da reformulação do sistema viário, incrementando o mercado imobiliário.

NEGRI (1996), apresenta um panorama geral do auge da industrialização na Capital e na área metropolitana e comenta o processo de desindustrialização e interiorização das indústrias incentivado pelo governo e seu reflexo nas antigas concentrações.

O trabalho de NOBRE (2000), volta às colações de VARGAS, mostrando a expansão do uso terciário na região da Avenida Eng. Luís Carlos Berrini e sua conseqüente valorização e a importância da estratégia de promoção do empreendimento, apostando na mudança da teoria "o local faz o ponto" investindo 
em diferentes regiões como por exemplo, na Cidade Líder $^{8}$ segundo a idéia de que "o ponto faz o local".

Por fim, a dissertação de BARBOSA (2001) focaliza a dinâmica das transformações no uso do solo no século $\mathrm{XX}$ para a região do centro expandido segundo os limites determinados pela Emplasa, relacionando essas modificações as alterações na lei de zoneamento e a expansão dos bairros.

\subsection{Infra-estrutura versus uso do solo: potencial de adensamento, valorização imobiliária e segregação urbana}

\section{$\underline{\text { Potencial de adensamento }}$}

A infra-estrutura deve ser o meio de integração entre as habitações e a população e, por seu caráter evolutivo ao longo do tempo, tem ligação direta com o "planejar" das cidades, devendo estar sob constante vigilância, evitando a subutilização de recursos em áreas onde está totalmente implantada e também o adensamento em áreas onde é inexistente.

Em 1971, os estudos de MALISZ, fornecem a idéia da Teoria dos Limiares, utilizada para estudos de implantação das redes e sua máxima utilização.

O trabalho de VILLAÇA (1978, p.34), menciona o adensamento como efeito indireto e positivo das obras públicas de infra-estrutura no uso do solo urbano, embora ressalte que poucos são os casos que incentivem o aumento da densidade já que é comum ainda, mesmo em grandes cidades, haver expressivo déficit nos serviços públicos.

A esse respeito, vários autores são unânimes em afirmar que, quanto maior a densidade, menor é o custo de implantação da rede, principalmente se esta afirmativa for vista sob o ângulo do poder público; por outro lado se faz necessário o controle desse adensamento visando a não sobrecarga e colapso das redes: “O adensamento da população consumidora amplia quantitativamente os mercados sem expandí-los espacialmente, às vezes até comprimindo-os em áreas menores. Por outro lado, a

${ }^{8}$ NOBRE, 2000, menciona como importante exemplo dessa teoria o Distrito da Cidade Líder, comentando a implantação na última década de vários centros de comércio: Shopping Leste Aricanduva, Shopping Interlar, Castorama e Auto Shopping Leste. 
deterioração das condições ambientais, decorrente da sobrecarga da infraestrutura ou dos equipamentos, ou da implantação de funções novas que prejudicam as existentes, inviabiliza certos usos ou atividades, forçando a sua substituição por outros" (ZMITROWICZ, 1979, p. 51).

Partindo dessa teoria RONCA E ZMITROWICZ (1988), discutem limites de adensamento e expansão que sejam compatíveis com a capacidade suporte das infraestruturas urbanas ${ }^{9}$, com o objetivo de melhorar o aproveitamento dos recursos existentes, minimizando assim os custos decorrentes da expansão urbana: "Os sistemas de transportes e de comunicações, as infra-estruturas em geral, constituem, ao lado dos canais naturais de escoamento dos fluidos, as principais estruturas que sustentam o funcionamento das cidades. O seu aperfeiçoamento se torna importante à medida que se torna imprescindível a sua utilização para as atividades humanas quando estas se adensam e especializam. Os limites das suas capacidades dependem das tecnologias adotadas, e se projetam em números máximos de usuários potenciais...” (ZMITROWICZ, 1992, pg.3).

Na definição desse "limite" de ocupação, a legislação de uso do solo é importante instrumento na compatibilização do aproveitamento dos terrenos com a capacidade das redes públicas de equipamentos e serviços urbanos.

O relatório de ROLNIK et al. (1990), contribui para a idéia de adensamento de regiões bem supridas de infra-estrutura, incentivando o melhor uso dessas áreas e o controle da expansão periférica principalmente no tocante as redes de saneamento, mas faz ressalvas quanto a saturação da capacidade do sistema elétrico que inviabiliza o uso de certas regiões do centro por apresentarem desde o inicio da década de 90, alta densidade de carga, conforme aponta o estudo da SEMPLA ${ }^{10}$ de 1991.

No início dos anos 90, foi desenvolvida metodologia por GUALDA (ZMITROWICZ (org.), 1992, p. 32-33), visando compatibilizar oferta e demanda das

9 Este termo é definido como sendo o adensamento urbano mediante condições mínimas de atendimento e oferta do serviço, dada no tempo e no espaço, com indicadores passíveis de serem obtidos nos órgãos competentes (PROENÇA; ZMITROWICZ (org.), 1992).

${ }^{10}$ A verificação da condição das redes de infra-estrutura no Município de São Paulo foi apresentada pela SEMPLA no mapa: Comprometimento da Infra-estrutura urbana de 1991. 
redes de saneamento e energia elétrica do Município de São Paulo, com um índice de adensamento das áreas bem servidas, tendo como resultado preliminar: "A quantificação da disponibilidade da infra-estrutura de energia elétrica, e sua transformação em potencial de adensamento e estoque de área para construção, é função da região da região da cidade (que caracteriza a oferta de infra-estrutura) e do tipo de uso do solo (que caracteriza a demanda por energia elétrica)". No caso da rede de coleta de esgotos, "a existência da rede coletora constitui condição suficiente para o adensamento na maioria dos casos., tolerando utilização intensiva"; já a rede de abastecimento de água exige para avaliação da demanda, considerações sobre área construída e para a oferta, complexos procedimentos analisando a distribuição por setores de abastecimento.

Estudos de TOLEDO SILVA (1991); MASCARÓ (1992) e MIGLIORINI (1997), voltam a análise de potencial de adensamento através da utilização dos recursos de infra-estrutura disponíveis de maneira a dinamizar o uso do solo, incluindo além das redes de infra-estrutura, o dimensionamento do sistema viário e a verificação do desempenho ambiental da área a ser adensada e outros aspectos particulares da edificação como a insolação e ventilação.

Valorização imobiliária, localização e segregação urbana

Com respeito a influência do uso e ocupação do solo na valorização imobiliária e segregação urbana, SINGER apud VETTER (1975), SÓCRATES apud AMATO (1983), SANTOS (1990), GARCIAS (1991), MORETTI (1993), SOUZA (1994) e VILLAÇA (1998), apontam as questões sociais de localização como preponderantes na implantação dos serviços.

SINGER enfatiza o deslocamento de moradores de menor renda quando do impacto gerado no valor do uso do solo pela implantação dos serviços (VETTER; MASSENA, 1975, p.15).

VETTER e MASSENA (1975, p.2) concluem em estudo para as cidades do Rio de Janeiro: "existe influência dos investimentos públicos em infra-estrutura na distribuição de renda e riqueza...”; “os investimentos nos sistemas de água e esgoto 
foram concentrados principalmente em áreas de alta renda...em áreas mais pobres é atendida com maior velocidade as zonas industriais" 11 (idem, p.21).

Outro agravante desta questão é abordada por VETTER e MASSENA (1975, p. 49), lembrando que a periferia embora receba menos investimentos, acaba pagando maior valor de impostos por sua distância e menor adensamento, dificultando e encarecendo a implantação dos serviços.

No trabalho de AMATO é feita a verificação da conseqüência da localização das elites para a cidade e para a política de usos do solo, tendo como conclusão que: "a classe alta está nos lugares mais bem servidos, concentrando em número e qualidade de serviços, equipamentos e infra-estrutura, gerando uma distribuição desproporcional na área urbana” (SÓCRATES, 1983, pg. 70).

SANTOS (1990, p.55), faz uma relação entre os subdistritos com maior e menor renda e o número de ligações às redes de água e esgoto e afirma: "os bairros cuja população dispõe de uma renda alta são mais bem contemplados com serviços públicos do que aqueles onde a renda é mais baixa."

Continuando o raciocínio, GARCIAS (1991, p.26), menciona Kowaltowski ${ }^{12}$, que em trabalho de 1989, sobre Planos Diretores, expõe a lei da "murphologia" urbana: "toda a cidade cresce no sentido inverso de sua infra-estrutura. Isso é em parte explicado como efeito do 'progresso', já que as populações de baixa renda fogem das áreas que recebem melhorias de infra-estrutura para áreas menos valorizadas".

Partindo dessa colocação MORETTI (1993, p.32), comenta o reflexo desse fato para a classe pobre: "Os interesses da especulação imobiliária ${ }^{13}$, amparados por uma legislação omissa ou conivente, geraram ao longo de todo este século, uma extensa área loteada na periferia da cidade, com padrões de infra-estrutura,

${ }^{11}$ Parte dessa verificação é feita neste trabalho nos capítulos 3 e 4, quando analisamos a influência das redes nos usos do solo.

${ }^{12} \mathrm{O}$ trabalho mencionado por Garcias intitulado: "Murphologia de Planos Diretores", foi apresentado por Kowaltowski, Doris C.C.A. e está nos Anais do Seminário Planos Diretores municipais. São Paulo, Faculdade de Arquitetura e Urbanismo da Universidade de São Paulo, 1989.

13 Entendemos por "especulação imobiliária",a relação entre oferta e demanda por lotes ou imóveis, oriunda da retenção dos mesmos, muitas vezes aguardando por "benfeitorias" e a consequente valorização da área; um "jogo de interesses" para a determinação do melhor momento de efetuar um negócio. 
urbanização e serviços públicos, que podem ser considerados sub-humanos. Cabe destacar que este quadro não é privilégio dos loteamentos clandestinos ou irregulares, sendo também observado nos empreendimentos aprovados e implantados."

Segundo KOWARICK: "os grupos que se apropriaram das novas áreas criadas pelas benfeitorias são de classe social mais elevada" (SOUZA, 1994, p.173).

VILLAÇA (1998, p. 143) resume a divisão da cidade em classe sociais: "o mais conhecido padrão de segregação da metrópole brasileira é o do centro $\mathrm{x}$ periferia. O primeiro, dotado da maioria dos serviços urbanos, públicos e privados, é ocupado pelas classes de maior renda. A segunda, subequipada e longínqua, é ocupada predominantemente pelos excluídos."

PINÇON -CHARLOT, constata em seu trabalho: "uma correlação entre a classe social que ocupa determinada região e os equipamentos públicos de que ela é dotada" (VILLAÇA, 1998, p.150).

Estudos específicos para o Município de São Paulo, verificam que com o grande crescimento da cidade de São Paulo no final do século XIX, criou-se a necessidade da implantação de infra-estrutura na Cidade acompanhando a reestruturação exigida por seu incremento populacional e econômico, desencadeando a expansão da periferia e a concentração da população de maior poder aquisitivo em áreas centrais.

KOWARICK (1979), focaliza o processo de valorização e consequente especulação imobiliária, baseado na importância da infra-estrutura: "um loteamento nunca é feito em seguida ao último, deixando-se sempre uma área intermediária que incorpora toda a infra-estrutura urbana que foi obrigada a passar por ela, valorizandoa. As zonas de especulação imobiliária, porém, não são apenas os terrenos situados entre um centro e suas zonas mas também os localizados dentro da própria área central, quando zonas 'estagnadas' recebem investimentos em serviços ou melhoria de infra-estrutura básica, o que repercute imediatamente no preço do terreno." (SOUZA, 1994, p.172).

SOUZA (1994, p. 173), comenta sobre a verticalização da cidade: "não há como negar que à geografia da localização corresponde uma geografia da 
valorização, nitidamente acoplada, no seu processo de expansão, às disponibilidades de infra-estrutura, em decorrência das quais os pobres vão sendo permanentemente rechaçados."

ROLNIK (1997, p.147), expõe que com a implantação de bairros na direção oeste da cidade de São Paulo, voltados para a classe abastada, munidos de toda infra-estrutura, teve início o processo do mercado imobiliário baseado na existência das chamadas "benfeitorias" e da especulação sobre a valorização dessas áreas em detrimento a outras, consideradas populares : “... a lógica e a racionalidade das companhias privadas...atender às demandas com capacidade de pagamento dos serviços ofertados e, se beneficiar da valorização gerada pela própria provisão do serviço."

PICCINI (1997, pg.44), também descreve o histórico da valorização do centro, oriunda da implantação de infra-estrutura: "Conforme a área era servida pela rede, seus terrenos ganhavam um diferencial de valor, permitindo, a quem podia pagar por eles, conquistar áreas privilegiadas para a formação de bairros exclusivos e livres de 'epidemias'... “

A importância da variável espaço e de suas consequiências no território é resumida por SMITH: “o espaço gera desigualdades. A localização de cada nova facilidade favorece ou desfavorece aqueles que se localizam perto, e isso redistribui o bem-estar e o mal-estar". (VETTER; MASSENA, 1975, p.3).

Fica claro que são inúmeros os fatores que influenciam a relação entre uso do solo e existência de infra-estrutura e sua velocidade de implantação, assim como, são várias as conseqüências que a expansão do serviço pode ocasionar em uma região.

Este trabalho não tem como objetivo a verificação dessa complexa problemática, pois sabemos a priori que outros parâmetros interagem na expansão da cidade e em sua característica de provisão dos serviços por região, exigindo uma análise detalhada de cada uma das áreas em diferentes períodos.

Desta forma, pretendemos apresentar aqui, informações sobre a evolução da infra-estrutura que possibilitem em trabalhos futuros, a utilização destes dados e a inclusão de outros aspectos na ordenação da estrutura urbana. 


\title{
Capítulo 2. Breve histórico sobre a evolução das redes de infra-estrutura no Município de São Paulo
}

\author{
"A infra-estrutura urbana influi decisivamente \\ no preço da terra e certamente também na \\ estrutura e forma urbana. É importante explicar \\ a evolução das redes de infra-estrutura $e$ \\ transportes para entender a própria evolução \\ das cidades." \\ (SOMEKH, 1997, p.115).
}

\subsection{Introdução: as redes de infra-estrutura no Mundo e no Brasil}

No passado, a dificuldade de comunicação entre as localidades e países, aliada ao desconhecimento do "novo", parecia ser o principal fator da morosidade no uso de novas técnicas. Hoje, nenhuma dessas duas questões pode ser considerada obstáculo para a divulgação e utilização de descobertas. Mas, o descaso nos países mais pobres com as cidades menos desenvolvidas, principalmente no campo das questões sanitárias, é ainda motivo de certo desalento quando pensamos na incapacidade da humanidade de associar a tecnologia - que sem dúvida está e ira ser cada vez mais avançada - às questões sociais.

$\underline{\text { Saneamento: abastecimento de água e coleta de esgotos }}$

Quando fazemos referência a cronologia das redes de infra-estrutura, as obras hidráulicas são as primeiras a serem mencionadas. Desde o período anterior a Era Cristã, encontramos citações sobre redes de irrigação, água, galerias de esgoto e drenagem. Em 3750 A.C., foram construídas as galerias de esgotos de Nipur (Índia) e da Babilônia; em 3100 A.C., já se empregava manilhas cerâmicas; registros comentam que no período de 2200 A.C., foram realizadas diversas obras hidráulicas na China; em 1700 A.C., temos notícia de um poço com 100 metros de profundidade aberto em região próxima ao Cairo e também na África, em 1050 A.C. são empregados os primeiros medidores de água.

No ano de 940 A.C., Salomão, rei dos Israelitas constrói grandes reservatórios; no período de 920 / 625 A.C. são executados os primeiros aquedutos: 
Vale do Cedron, Tróia, Megara. Em 600 A.C., a primeira captação através de bombas para alimentação das fontes dos jardins suspensos da Babilônia; em 312 A.C., construção do aqueduto Appia, o mais antigo de Roma, marcando o longo domínio romano nas obras hidráulicas. (vide AZEVEDO NETTO, Revista RAE n. 137, 1983).

Caminhando por vários séculos ${ }^{14}$, são verificados avanços através de obras grandiosas como os aquedutos de Segóvia e Terragona (Espanha) e Bardo em Cartago (África); em 1237 é construída em Londres a primeira rede de água encanada; 240 anos depois, ainda na mesma cidade, ampliação da rede, culminando em 1613, com a criação da Companhia de Água New River. Em 1835 são criadas normas para a execução de esgotos na Alemanha; são da mesma época as galerias de esgotos de Paris, famosas pelo seu desenho e dimensões. (vide MASCARÓ, 1987; BENÉVOLO, 1993).

No Brasil , em 1673 tem início as obras de adução de água para o Rio de Janeiro, mas é no século XIX, que a questão ganha importância: além do Rio de Janeiro e de São Paulo (que comentaremos com detalhes a seguir), Recife, Porto Alegre, Belo Horizonte ( entre as maiores cidades do país), através de expoentes como Aarão Reis, Francisco Bicalho, Paulo de Frontin, passam do uso de chafarizes públicos a rede encanada. Assim também são criados projetos de saneamento para as mesmas cidades (inclusive algumas do interior de São Paulo) pelas mãos do Engenheiro Francisco Saturnino de Brito, considerado o maior nome da engenharia hidráulica e sanitária do país. (vide TELLES, 1984, v.1,v.2).

\section{Energia: gás e energia elétrica}

Gás

Passando para os sistemas de geração de energia - de aparecimento posterior em 1812, surge na Inglaterra, a primeira companhia de distribuição de gás, primeiro com a finalidade de iluminação pública, depois para a iluminação residencial e para aquecimento; três anos mais tarde, são feitas tentativas em algumas cidades dos Estados Unidos. No Brasil, existe uma controvérsia sobre qual foi a primeira cidade

${ }^{14}$ São desse período as fontes de bombeamento executadas pelos maias. Relatos mais detalhados sobre a evolução da rede na América pré-colombiana não foram localizados. 
com iluminação a gás: São Paulo ou Rio de Janeiro; a primeira é considerada por vários autores a precursora, datando as primeiras experiências de 1860/70, embora TELLES (1993), mencione que em 1834, já havia sido iluminado o Largo do Paço (atual Praça XV de Novembro) nessa outra cidade. Outras cidades como por exemplo, Porto Alegre, passaram a ser iluminadas por gás canalizado ainda na antepenúltima década do século XIX ${ }^{15}$. No final desse período, também possuíam o serviço: Belém, São Luiz, Fortaleza, Salvador, entre outras.

Na década de 70, através da construção de gasodutos, ligando países e continentes houve grande expansão da rede formando as chamadas "rotas mundiais de gás natural".

Em nosso país, a ampliação desse serviço ainda está em desenvolvimento com a utilização do gasoduto Brasil-Bolívia.

Atualmente, existe interesse em projetos de co-geração de energia, visando o trabalho conjunto entre usinas hidrelétricas e termelétricas, como por exemplo, o projeto da Comgás para a ampliação da Usina termelétrica de Piratininga (iniciado em 2001) e de criação da termelétrica de Cubatão.

\section{Energia elétrica}

A eletricidade gerada por atrito, é conhecida desde a antiguidade grega. Durante o século XVII, vários foram os estudos nesse campo, sem conseguir chegar a utilização prática. Em 1752, Franklin criou o pára-raios, através de investigações sobre a eletricidade atmosférica. Ainda no século XVIII, Cavendish e Priestley formulam teorias sobre o comportamento das argas elétricas em condutores, mas somente em 1801 surgem os primeiros resultados concretos através de Volta, com a criação da primeira pilha produzindo corrente estável e a seguir, Faraday, com o projeto de geradores elétricos e Edison, criando a lâmpada incandescente, possibilitando a iluminação pública.

Mas, ainda era desconhecido o mecanismo para estender o serviço a locais distantes do ponto inicial. Em 1888, a transmissão de energia se tornou possível, através da invenção de transformadores em alta tensão e da implantação de

${ }^{15}$ Lembrando que no final do século XIX, teve início a introdução da energia elétrica, como mencionamos a seguir. 
subestações para conversão em média e baixa voltagem próximas a área a ser servida, através de Westinghouse. Nessa época, foi instalada a primeira usina nas cataratas do Niáguara e difundido o uso da energia elétrica por todo os Estados Unidos e Europa ${ }^{16}$, incrementando a era industrial.

No Brasil, a primeira experiência com eletricidade, remonta a introdução do telégrafo elétrico no Rio de Janeiro e no Rio Grande do Sul. Em meados de 1868, foi realizada a primeira experiência para iluminação de uma fachada em São Paulo, a seguir sendo iluminadas a cidade de Rio Claro (SP) e Campos (RJ); na mesma época, outras cidades do país eram ligadas ao telégrafo. Em 1885, teve início as primeiras tentativas de iluminação elétrica no Rio de Janeiro e dois anos mais tarde, em Porto Alegre (vide TELLES, 1984, v.2).

No campo da geração de energia, aproveitando o grande potencial hidrológico do território e acompanhando o desenvolvimento tecnológico do outros países ${ }^{17}$ foram sendo instaladas as primeiras usinas hidrelétricas em Minas Gerais : Ribeirão do Inferno (1883) e Ribeirão dos Macacos (1887), seguidas por São Paulo (como veremos adiante, na descrição do importante papel do grupo Light nessa cidade e no desenvolvimento do país). Como brilhantes expoentes nesse campo, podemos mencionar os engenheiros Edgar Egydio de Souza ( brasileiro que chegou ao posto de Superintendente dos negócios da Light em todo o país), Asa White Billings (engenheiro da antiga Light), Dulcídio de Almeida Pereira, Otto de Alencar, entre outros.

Em 1901 é construída a Usina de Parnaíba, primeira hidrelétrica de grande porte do Brasil. Nos primeiros dez anos do século 20, as indústrias eram quase todas movidas a vapor ou a força hidráulica, sendo a eletricidade comum somente para a iluminação e na alimentação de bondes. Até o final da década de 30 o uso industrial era o principal responsável pelo consumo de energia elétrica, embora ainda inexpressivo. Na década de 50, com o grande incremento dessa área e com o advento da televisão e de outros equipamentos movidos a eletricidade (além do

\footnotetext{
${ }^{16}$ Vale lembrar que embora com a grande difusão da rede, existia na Europa, até a metade do século XX, edifícios com utilização de iluminação e energia a gás.

17 Alguns autores afirmam que este é um dos campos da tecnologia que melhor se desenvolveu em grande parte do país.
} 
incremento industrial) houve considerável avanço na geração e distribuição de energia para o país.

O século XX foi denominado de o "século da eletricidade", porque nenhuma outra descoberta teve tão grande influência em todos os aspectos da vida humana. (TELLES, 1984, v.2, p.418).

Telecomunicações : telefonia e cabos ópticos

\section{Telefonia}

Inventos anteriores como o "telégrafo ótico" de Claude Chappe (1791), a "pilha elétrica" de Alexandre Volta (1801), o "telégrafo eletroquímico" de Von Soemmerring (1809) e o "telégrafo elétrico" de Samuel Morse (1837) são exemplos do caminho percorrido pelos cientistas até em 1876, quando foi patenteada a invenção do telefone por Alexandre Graham Bell.

No Brasil, em 1878 no Rio de Janeiro, instala-se o primeiro telefone; em 1879, Dom Pedro II autoriza o funcionamento da primeira "Companhia Telephonica Brasileira", servindo essa cidade e em 1883 é instalada uma estação telefônica na cidade de Santos (SP). Em 1884 entram em funcionamento os primeiros telefones de São Paulo. No início da década de 10, várias cidades já contavam com o serviço nos estados de Minas Gerais, Santa Catarina (Florianópolis-1911), Mato Grosso (Cuiabá e Várzea Grande - 1913); Rio Grande do Sul (Porto Alegre- Caxias do Sul, Pelotas 1916), sem contar os aparelhos no antigo Distrito Federal e Bahia. Em 1918, os demais Estados ainda só possuíam telefones nas respectivas capitais. Em São Paulo, nas duas décadas seguintes, o serviço telefônico teve grande expansão, embora após os anos 40, tenha permanecido quase estagnado, voltando a crescer na década de 90 , após a privatização, também incrementada com a introdução dos aparelhos celulares.

\section{Cabos ópticos}

A tv a cabo nasceu nos Estados Unidos em 1948, como forma de melhorar a recepção dos sinais das emissoras convencionais. A invenção do laser no final da década de 50, impulsionou o desenvolvimento das comunicações ópticas, levando a 
obtenção do laser semicondutor (1962) e de fibras ópticas (1970), tornando viável seu uso em telecomunicações (MUSEU DO TELEFONE, 2000).

A segunda expansão, ocorreu em 1976 na Inglaterra, com a mesma função para a televisão. A ligação entre os diversos países foi projetada por meio de cabos submarinos interconectando os Estados Unidos a Europa e a Ásia (cabo conhecido como Columbus I) e com os países sul-americanos (cabo Unisur).

No Rio de Janeiro em 1984, são instalados os primeiros cabos do Brasil, introduzindo o serviço público de correio eletrônico. Um ano depois, acontece a implantação em São Paulo entre as Estações de Basílio da Gama e Santa Efigênia. Em 1993, o sistema terrestre é instalado definitivamente, ligando o Rio de Janeiro a São Paulo. No ano seguinte, o Brasil é ligado a rede mundial de fibras ópticas por meio de instalações submersas; aos Estados Unidos pelo cabo Americas 1 e juntamente com a Argentina, a Europa e Ásia, por meio do cabo Atlantis II. Em sequência, as principais cidades do Brasil são interligadas pela rede, que em geral, é construída ao longo de rodovias.

Atualmente, a utilização desse serviço para otimização na transmissão de dados computacionais é a área de maior interesse, criando um trabalho conjunto entre a concessionária de energia (que muitas vezes aluga o poste para a distribuição dos cabos por via aérea) e das empresas de telefonia (criando sistemas aumentando a velocidade de acesso a internet por meio dos cabos ópticos). (EMBRATEL, 2000).

\subsection{Saneamento básico}

\subsubsection{Concessão dos serviços}

Segundo historiadores, o abastecimento de água da Capital começou com a captação das nascentes do Jacuba, Açú Gavo e Moranguinho e em 1744, houve a primeira experiência para adução de água por conduto, elaborada pelos frades franciscanos para seu próprio consumo.

No século XIX, o suprimento de água da cidade era feito por chafarizes ou pipas a porta. Em 1842, José Joaquim da Costa Henriques, elaborou um primeiro plano para adução e distribuição de água, recusado pelo governo da Província. 
Em 1863 foi apresentado novo projeto, propondo o uso do manancial da Cantareira e através de contrato entre o Governo da Província e a concessionária representada pelo coronel Antonio Proost Rodovalho, o major Benedicto Antônio da Silva e Daniel Makinson Fox, foi então formada a Companhia Cantareira de Águas e Esgoto, que iniciou a obra proposta.

Em 1877, a mesma concessionária solicitou um contrato para concessão de "um sistema completo de esgotos e despejos dos prédios desta capital".

Até 1892, os serviços foram prestados por essa empresa, quando o Governo do Estado decidiu rescindir o contrato celebrado pela impossibilidade, confessada pela própria Companhia de cumprir o prometido (vide Revista R.A.E., n. 2, 1937, p.203).

Assim, por decreto de janeiro de 1893, foi criada a Repartição de Águas e Esgoto da Capital.

Em 1905 (com modificações em 1926), depois da crise no abastecimento de água, foi instituída a comissão das Obras de Saneamento da Capital, a qual caberia, (entre outras determinações) um estudo para o Plano Geral da rede de águas pluviais e esgotos. Na década de 30 foi elaborado um "plano de emergência" visando regularizar e expandir o abastecimento de água da Capital.

Até 1954, o panorama administrativo se manteve o mesmo (salvo decretos criando seções internas a Repartição). Nesse ano, foi criado o DAE (Departamento de Águas e Esgotos), que tinha sob seu comando, além da Capital, os municípios vizinhos do $\mathrm{ABC}$ e Guarulhos, sendo submetido a Secretaria de Viação e Obras Públicas.

No início dos anos 60, foi aprovado um plano criando seis sistemas para coleta e tratamento de esgotos, que incluiam os municípios vizinhos do $\mathrm{ABC}$, Guarulhos, Mauá e Osasco. Em 1968 e 1970, respectivamente, foram criadas a Comasp ( Companhia Metropolitana de Água de São Paulo), a Sanesp (Companhia Metropolitana de Saneamento de São Paulo) e o FESB (Fomento Estadual de Saneamento Básico).

Em 1973, com o Planasa ( Plano Nacional de Saneamento) todas as empresas foram reunidas em uma única, responsável pelo abastecimento de água e coleta de 
esgotos - a Sabesp (Companhia de Saneamento do Estado de São Paulo) que até hoje coordena esses serviços na Capital e em mais 672 municípios do Estado.

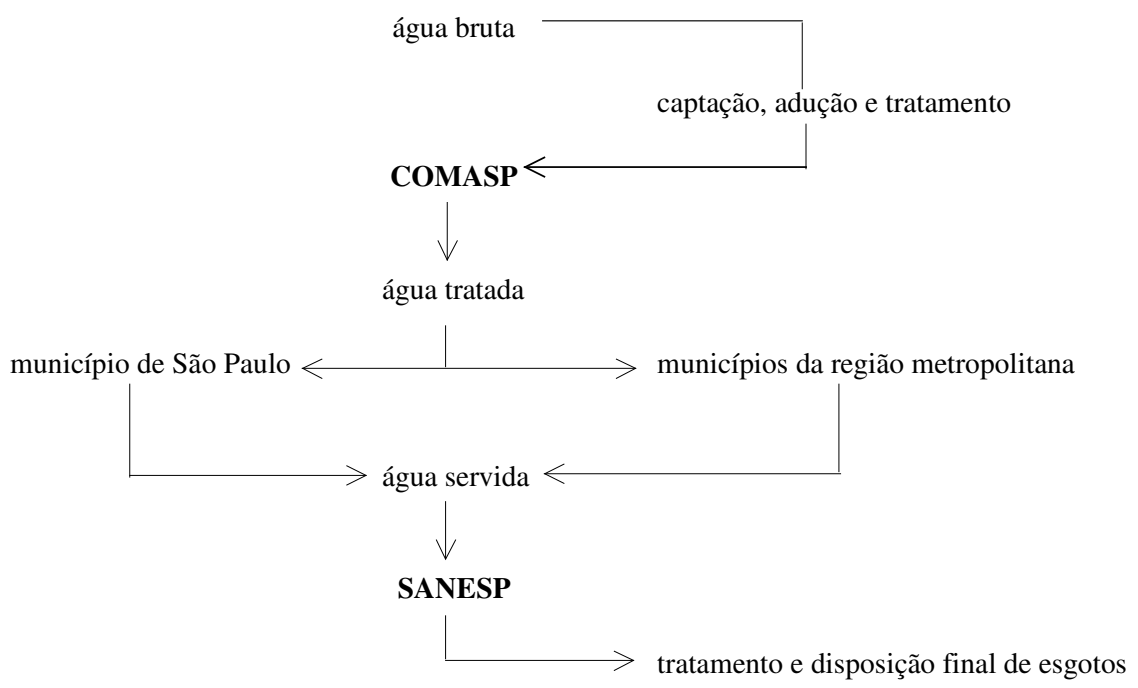

Figura 2.1. Esquema de funções das empresas de saneamento básico em 1970. Fonte: Elaboração do esquema a partir de dados da Revista DAE, n.76, 1970.

Em 1995, foi instituída a divisão do Estado em 5 Unidades de Negócios, utilizando como unidades de planejamento, as bacias hidrográficas. O município de São Paulo, por sua complexidade é o único integrante da Unidade Centro.

Na gestão interna da cidade, a empresa utiliza desde 1969, os "Distritos Regionais da Superintendência de Água e Esgotos da Capital - SAEC”, que inicialmente foram divididos em : Centro, Santo Amaro, Lapa, Santana, Penha, Ipiranga, Mooca e Vila Mariana.

Conforme a ampliação da rede e aproveitamento de novos sistemas de captação, esses distritos foram sendo subdivididos e em 1987, apresentavam a seguinte estrutura: 
- Centro, Ipiranga, Mooca, Lapa, Penha, Pinheiros, Santana, Santo Amaro, Vila Mariana, Pirituba, São Miguel Paulista, Freguesia do Ó, Vila Maria, Capela do Socorro, Itaquera, Vila Prudente, Butantã e Campo Limpo.

Em 1997, essa divisão passou por pequenas alterações no perímetro das administrações, mas manteve estrutura semelhante.

A criação da Sabesp incrementou a evolução dos serviços. Nos anos de 1975 a 1978, projeto visando grande expansão do sistema de abastecimento de água da região metropolitana, começou a ser executado.

Na década de 90, teve início o Projeto Tietê (1992), tendo como principais objetivos a melhoria do sistema de coleta de esgotos e despoluição do rio Tietê, (com a primeira fase encerrada com a entrega das novas estações de tratamento em 1998 e a segunda fase em andamento).

As décadas de 80 e 90, constituem o período de maior evolução do saneamento na grande São Paulo, que além de ampliar as redes, vêm intensificando os estudos e ações para a proteção de mananciais e para o combate ao desperdício de água, através do projeto PURA (programa de uso racional da água), visando o equilíbrio na utilização dos recursos naturais e conseqüente qualidade de vida.

Abaixo, apresentamos em síntese, a cronologia de concessão dos serviços de saneamento:

1875: Companhia Cantareira de Água e Esgotos

1893: RAE (Repartição de Águas e Esgotos da Capital)

1954: DAE (Departamento de Águas e Esgoto)

1968 :Comasp (Companhia Metropolitana de Água de São Paulo)

1970: Sanesp (Companhia Metropolitana de Saneamento de São Paulo) e o FESB (Fomento Estadual de Saneamento Básico)

1973: Sabesp (Companhia de Saneamento do Estado de São Paulo)

A Sabesp é uma empresa de economia mista, de capital aberto ${ }^{18}$ (característica desde a criação da Comasp, em 1968), que tem como principal acionista o Governo do Estado de São Paulo e que atua como concessionária do serviço sanitário municipal.

\footnotetext{
${ }^{18}$ Não foi localizada a descriminação das empresas privadas que formam o capital aberto da empresa.
} 


\subsubsection{Abastecimento de água}

\subsubsection{Evolução da distribuição territorial da rede}

A expansão do serviço não acompanhou o grande crescimento da cidade. Em 1899, relatório afirmava: "Há nesta Capital bairros populosos e importantes que não têm ainda o necessário abastecimento de água: Perdizes, Água Branca, Lapa, Vila Cerqueira Cézar, Vila Clementino...não tem ainda água canalizada e não a terão de certo enquanto não se fizerem obras complementares...” (MOTTA, 1911, 25).

Dados de relatório de 1927, caracterizam os bairros servidos e seu consumo diário:

\begin{tabular}{|c|c|c|c|c|c|}
\hline Centro & Consumo Diário (m3) & Norte & Consumo Diário (m3) & Leste & Consumo Diário (m3) \\
\hline $\begin{array}{l}\text { Santa Cecília } \\
\text { Bom Retiro }\end{array}$ & $\begin{array}{c}27800 \\
8187\end{array}$ & $\begin{array}{l}\text { Santana } \\
\text { Nossa Senhora do Ó }\end{array}$ & $\begin{array}{c}62512 \\
1875 \\
\end{array}$ & $\begin{array}{l}\text { Mooca } \\
\text { Penha }\end{array}$ & $\begin{array}{c}26100 \\
5325 \\
\end{array}$ \\
\hline Santa Ifigênia & 16050 & \begin{tabular}{|c|} 
Sul \\
\end{tabular} & Consumo Diário (m3) & & \\
\hline Belenzinho & 78250 & Vila Mariana & 72500 & & \\
\hline Bela Vista & 52375 & Ipiranga & 27112 & & \\
\hline Sé & 10500 & Oeste & Consumo Diário (m3) & & \\
\hline Consolação & 32250 & Perdizes & 46150 & & \\
\hline Cambuci & 16600 & Lapa & 51800 & & \\
\hline
\end{tabular}

Tabela 2.1. Setores de abastecimento e consumo diário em 1927.

Fonte: Motta, A., 1927.

No período de 1929/30, como mencionamos anteriormente, foi executado um plano de emergência, com o intuito de reforçar o abastecimento dos reservatórios já existentes e expandir a rede para outros distritos. O esquema a seguir (figura 2.2.) resume a situação do sistema na época: mananciais e reservatórios existentes com seus respectivos setores de abastecimento.

Também na década de 40, houve grande preocupação com a revisão do sistema. Em 1946, foi apresentado um relatório pelo Diretor do R.A.E., Plínio Whitaker utilizando um mapa de 1942, indicando que ainda não eram abastecidos:

- Na Zona Oeste: Vila Leopoldina, Bela Aliança, Vila Romana, Vila Ipojuca e Alto da Lapa; 
- Na zona Norte: bairro do Limão, a parte alta da Casa Verde, Tucuruvi, Vilas Mazzei, Leonor, Gustavo, Guilherme e Maria ( parte alta e baixa) e parte do Carandirú;

- Na Zona Sudeste: Vilas Prudente, Alpina, Pedro I e Independência;

- Na Zona Sudoeste: Vilas Conceição e Madalena e o Itaim-Bibi;

- $\quad$ Na Zona Sul: Bosque da Saúde, Jabaquara, Indianópolis e Alto do Brooklin.

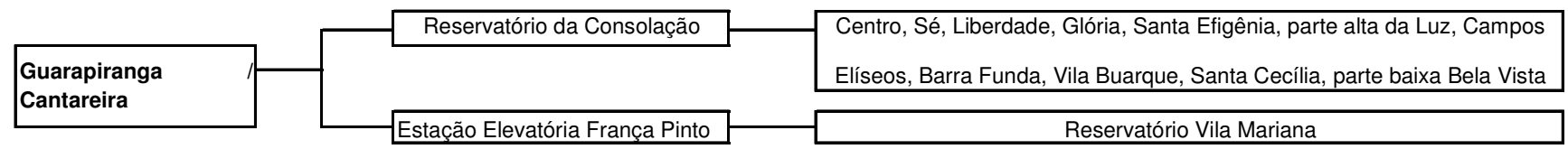

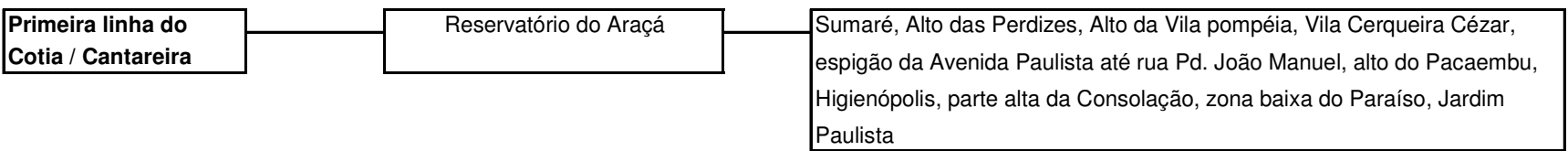

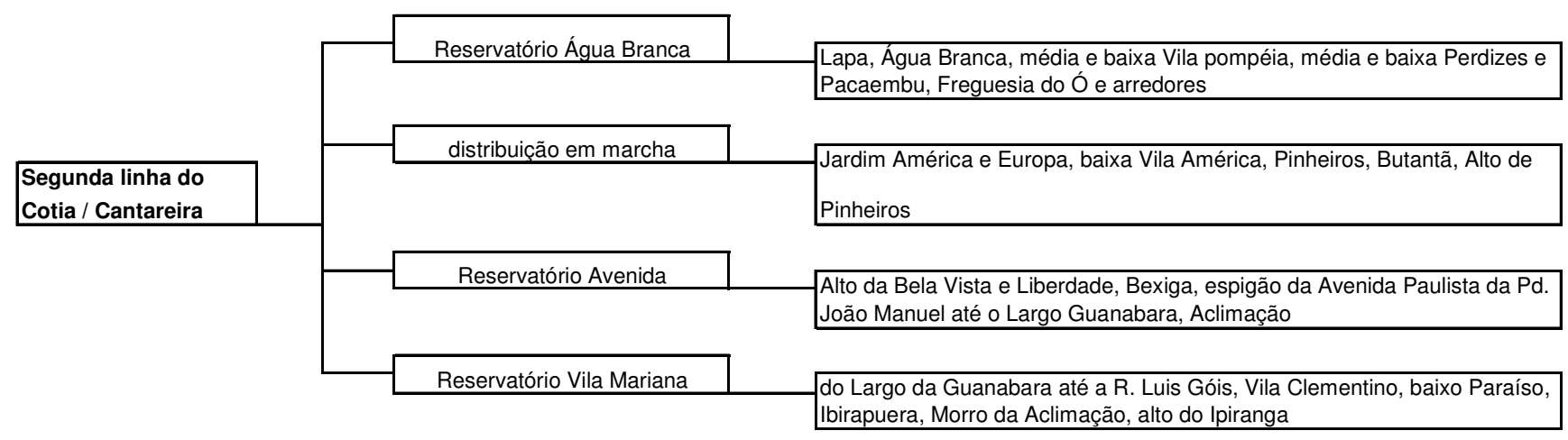

Figura 2.2. Esquema simplificado do sistema de abastecimento de água na Cidade de São Paulo em $1930^{19}$

Fonte: Elaboração do esquema a partir de dados da Revista RAE, n.17, 1946.

No final dos anos 50, a rede se concentra na região Central, caminhando pelo vetor Oeste em direção ao Butantã, um pouco ao Norte e a Leste. O relatório do Plano Urbanístico Básico de 1968, menciona que o abastecimento de água cobre 85\% da área ocupada, sendo as áreas não servidas todas em posição periférica.

O Censo Predial de 1970, realizado pelo IBGE, aponta as zonas Leste, Sul e parte da Norte, como as áreas com maiores porcentagens de inexistência da rede. 
Mantendo praticamente o mesmo perfil, em 1975 (PMSP, 1975, s.p.), considerando a divisão em administrações regionais da época ${ }^{20}$, verificamos que na regional de Campo Limpo a rede era inexistente; bastante precária nas áreas do Butantã, Santo Amaro, Ermelino Matarazzo/São Miguel Paulista, Itaquera/Guaianazes, Pirituba/Perus e Freguesia do Ó e com pontos críticos nas regionais Santana, Vila Prudente e Penha. O projeto elaborado no período 1975/78 expande bastante a rede na década seguinte.

Na segunda metade da década seguinte (PMSP; SEMPLA, 1986, s.p.), outro levantamento feito pela Prefeitura demonstra que na regional Freguesia do Ó, o problema havia sido sanado, assim como em praticamente toda a área de Itaquera/Guaianazes, São Miguel Paulista/Ermelino Matarazzo e Santo Amaro, sendo ainda bastante deficiente em Campo Limpo.

O levantamento do Censo de 1991, indica que os distritos com menor número de ligações a rede geral são: Anhanguera, Parelheiros e a pior situação em Marsillac (inexistência de domicílios ligados a rede). Outras áreas como a Cidade Tiradentes, Grajaú, Iguatemi e Jardim Ângela apresentam considerável número de poços ou nascentes assim como em menor escala, os bairros de Tremembé e Vila Maria.

O mapeamento de 1995 fornecido pela Sabesp, mostra que a rede foi implantada em praticamente todo o Município, com exceção de pontos do extremo Leste e Sul e, em 1997 afirma que praticamente toda a população tem acesso a rede de água. Deve ser ressaltado, que embora exista a canalização externa, na pesquisa por domicílios urbanos do Censo de 2001, 0,5\% das ligações não está vinculada a rede da rua, ou seja, ainda é superficial dizer que onde existe rede existe o serviço.

${ }^{19}$ Notar que neste esquema não foi incluída a área servida pelas obras de emergência para utilização do Rio Tietê. Outro ponto é a falta de detalhamento em separado dos setores abastecidos pelo manancial da Cantareira.

20 Lembramos que neste trabalho foi utilizada a divisão de 1991, expressa em administrações regionais com 91 distritos ao todo (vigente até a implantação em 2002, das 28 sub-prefeituras). Assim, para padronizar a organização dos distritos, listamos as modificações entre 1975 e 1991: Santo Amaro em: Capela do Socorro, Santo Amaro e Cidade Adhemar; Pirituba/Perus em: Pirituba, Jaguará e Perus; Vila Mariana em: Vila Mariana e Jabaquara; Freguesia do Ó em: Freguesia do Ó e Casa Verde; Santana em: Santana, Jaçanã e Tremembé; Mooca em: Mooca, Aricanduva e Vila Formosa; Vila Prudente em: Vila Prudente e São Mateus; Itaquera e Guaianazes em: Itaquera, Guaianazes e São Mateus. 
Gráfico 2.1. Extensão da rede de água $(\mathrm{km})$

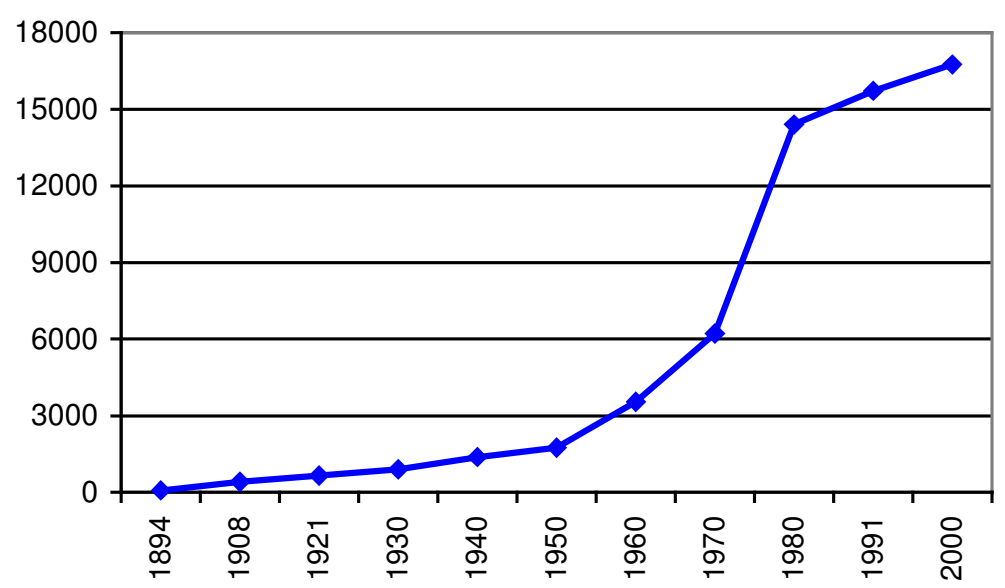

Gráfico 2.2. Evolução do número de ligações da rede de água

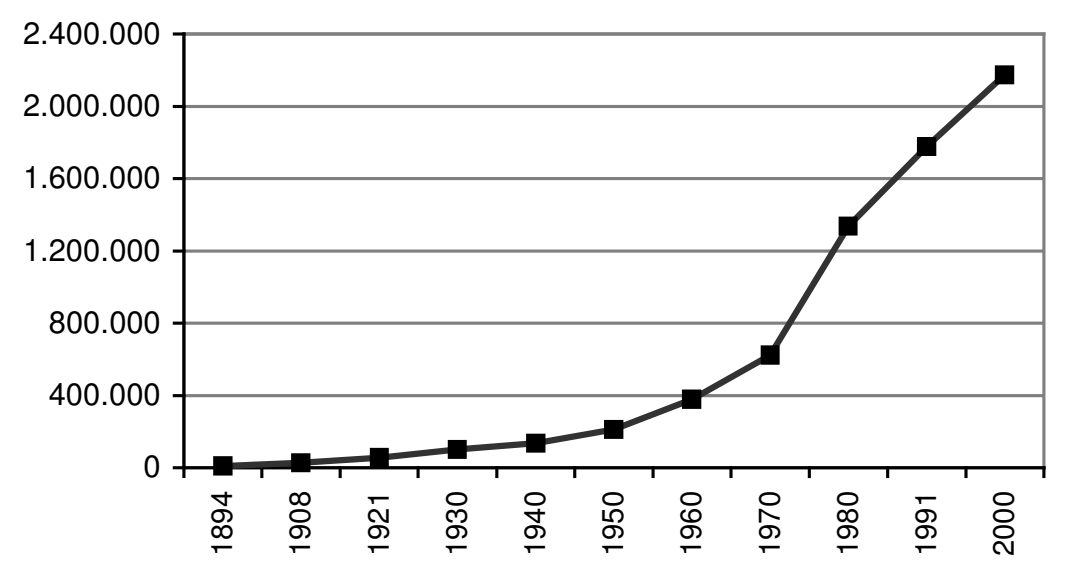

Gráfico 2.3. População atendida pela rede de água versus população total do Município

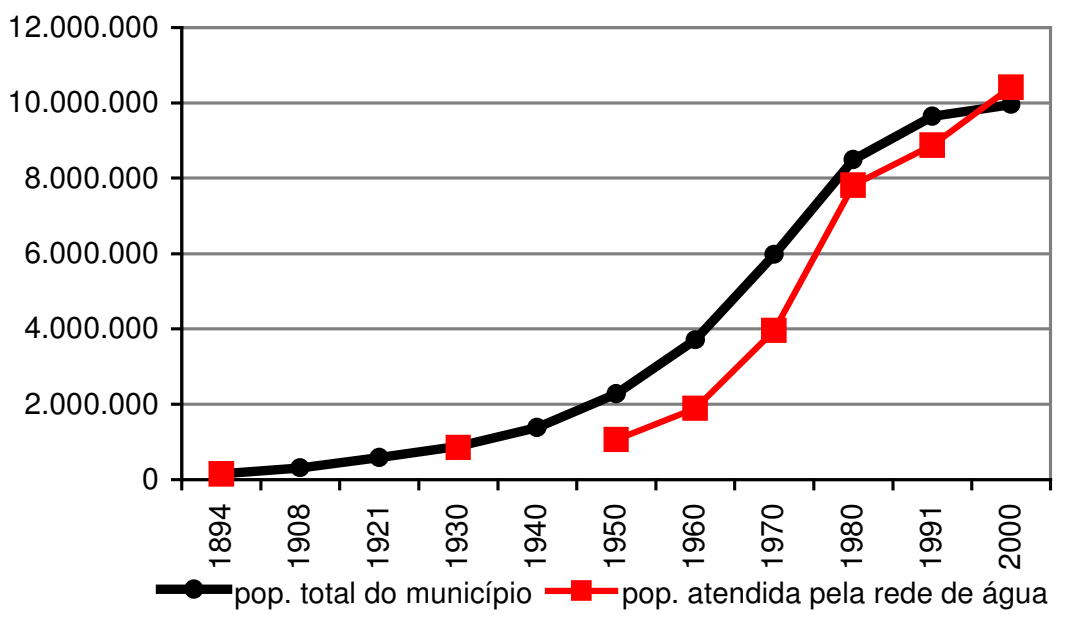


Tabela 2.2. Composição dos gráficos sobre a rede de abastecimento de água

\begin{tabular}{|c|c|c|c|c|c|}
\hline \multirow[t]{2}{*}{ Ano } & \multirow{2}{*}{\begin{tabular}{|l} 
GERAL \\
$\begin{array}{l}\text { população } \\
\text { total }\end{array}$
\end{tabular}} & \multicolumn{4}{|c|}{ ABASTECIMENTO DE ÁGUA } \\
\hline & & $\begin{array}{c}\text { Número Ligações } \\
\text { à Rede de água }\end{array}$ & $\begin{array}{l}\text { pop.atendida pela } \\
\text { rede de água }\end{array}$ & $\begin{array}{lr}\% & \text { pop. } \\
\text { Atendida }\end{array}$ & $\begin{array}{l}\text { extensão } \\
\text { da rede }\end{array}$ \\
\hline & (hab.) & & (hab.) & $(\%)$ & $(\mathrm{km})$ \\
\hline 1894 & 160.000 & 8.642 & 147.692 & 92,3 & 73 \\
\hline 1908 & 274.000 & 23.742 & \multicolumn{2}{|c|}{ não localizado } & 416 \\
\hline 1921 & 579.086 & 29.559 & \multicolumn{2}{|c|}{ não localizado } & 661 \\
\hline 1930 & 887.810 & 101.447 & 850.000 & 95,74121 & 968 \\
\hline 1940 & 1.378 .539 & 135.242 & \multicolumn{2}{|c|}{ não localizado } & 1.377 \\
\hline 1945 & 1.696 .493 & 179.218 & 771.904 & 45,5 & 1.585 \\
\hline 1950 & 2.278 .000 & 211.021 & 1.054 .714 & 46,3 & 1.758 \\
\hline 1955 & 2.916 .000 & 256.459 & 1.291 .788 & 44,3 & 2.164 \\
\hline 1960 & 3.709 .274 & 377.056 & 1.891 .730 & 51 & 3.543 \\
\hline $1964 / 65$ & 4.929 .674 & 513.130 & 2.770 .477 & 56,2 & 5.594 \\
\hline 1970 & 5.978 .977 & 622.810 & 3.360 .185 & 56,2 & 6.223 \\
\hline 1975 & 7.710 .000 & 787.270 & 5.242 .800 & 68 & 8.742 \\
\hline 1980 & 8.493 .226 & 1.334 .874 & 7.813 .768 & 92 & 14.403 \\
\hline 1985 & 8.864 .706 & 1.614 .077 & 7.978 .235 & 90 & 15.363 \\
\hline $1990 / 91$ & 9.646 .185 & 1.766 .267 & 8.874 .490 & 92 & 15.728 \\
\hline 1996 & 9.839 .436 & 1.969 .249 & 9.839 .436 & 100 & 16.659 \\
\hline 2000 & 10.406 .166 & 2.172 .440 & 10.406 .166 & 100 & 16.758 \\
\hline
\end{tabular}

Fonte:

Gráficos 2.1 e 2.2

Dado 1894:

Motta, A.. Estudos Preliminares para o reforço do abastecimento d' água na cidade de São Paulo, 1911.

Dado 1908:

Azevedo, A. A cidade de São Paulo, 1958.

Dado 1921:

Emplasa, Reconstituição da memória estatística da grande São Paulo, 1993.

Dados 1930/1975:

Companhia de Saneamento Básico do Estado de São Paulo - Sabesp, Revista do D.A.E., 1976.

Dados 1980/1991:

Emplasa, Sumário de Dados da Grande São Paulo, 1982/ 91.

Dado 1996:

Emplasa, Sumário de dados, 1997.

Dado 2000:

Prefeitura do Município de São Paulo, Prodam, 2001.

Gráfico 2.3.

População Total do Município: Instituto Brasileiro de Geografia e Estatística - IBGE.

População atendida pela rede de água:

Dado 1894: Motta, A.. Estudos Preliminares para o reforço do abastecimento d' água na cidade de São Paulo, 1911.

Dados de 1930/1950/1960/ 1965: Departamento de Águas e Energia Elétrica, Distribuição de Água e Coleta de Esgotos em São Paulo: afastamento e disposição de esgotos na região metropolitana, 1970.

Dados de 1970/ 1975/1985: Emplasa, Sumário de Dados da Grande São Paulo, 1977.

Dados de 1980: Secretaria Municipal de Planejamento - Sempla, Diagnóstico regionalizado do Município de São Paulo, 1983.

Dado 1991: Prefeitura do Município de São Paulo, Plano Diretor: Versão Preliminar, 1990.

Dado 1996/2000: Prefeitura do Município de São Paulo, Prodam, 2001. 


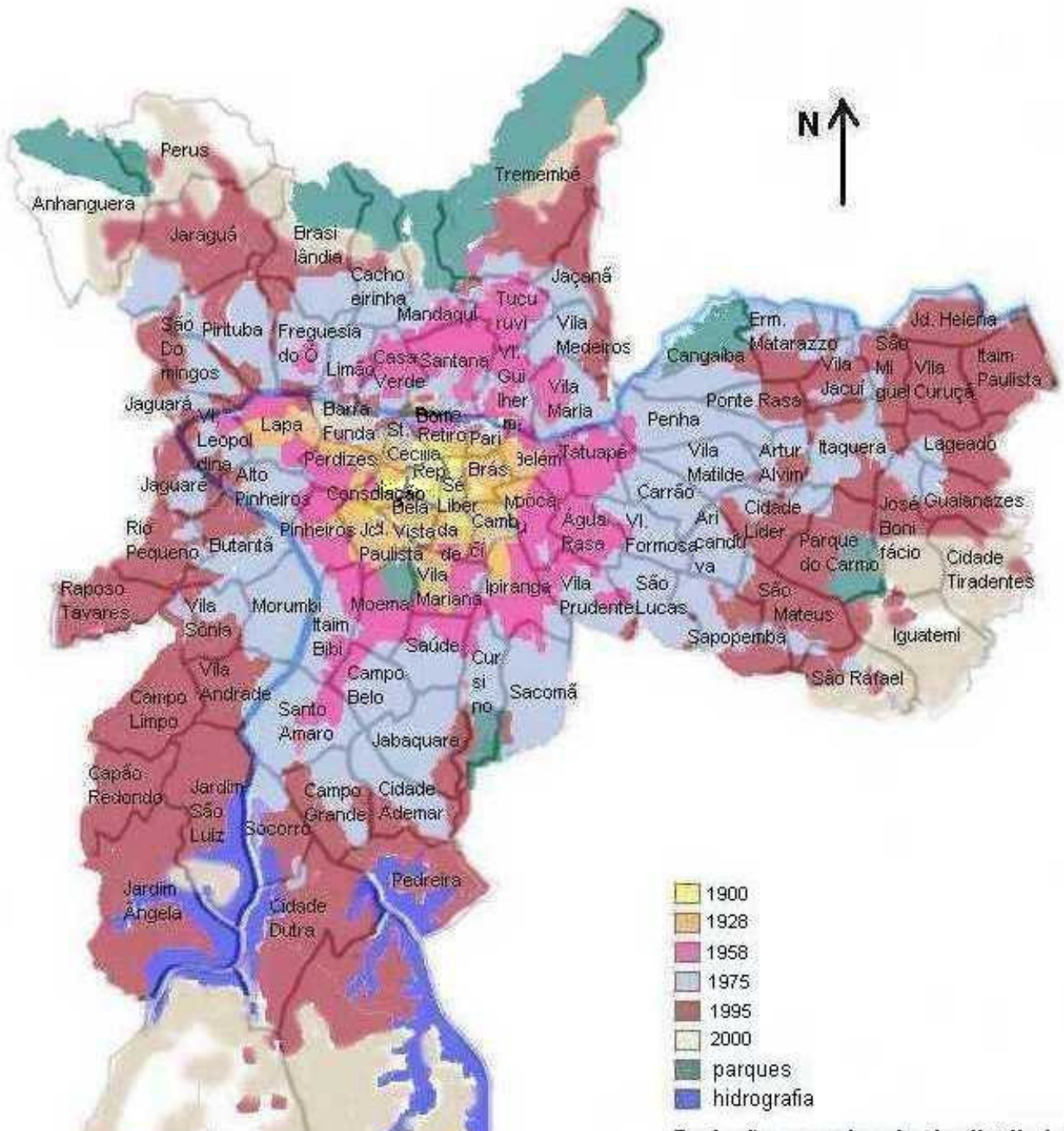

Evolução aproximada da distribuição territorial da rede de abastecimento de água no Município de São Paulo $1900-2000$

Fonte:

Rolnik, 1997.

PMSP, 1961.

PMSP, 1975/76.

SABESP, 2000.

PRODAM, 2001.

Obs.: Figura sem escala Elaboração: Massara, V.M., 2001

Figura 2.3. 


\subsubsection{Mananciais e adutoras}

Durante o período em que a Companhia Cantareira esteve no controle do fornecimento de serviços de água e esgoto, os mananciais explorados eram somente dois:

- os provenientes da Cantareira através de duas ramificações: 1) atendendo o centro da cidade a ligação entre a adutora do Guaraú e o reservatório da Consolação; 2) atendendo ao bairro do Paraíso e espigão da Avenida Paulista a ligação entre a "caixa" do Guapira e o reservatório da Liberdade (atual reservatório Avenida);

- os recursos do Córrego Ipiranga, represado no Bairro da Água Funda ( local onde atualmente se localiza o Jardim Zoológico) abastecendo a parte baixa da cidade: Brás, Mooca e Ipiranga.

Em 1893, com a R.A.E., foi melhorada a adução das águas do Ipiranga, aumentada a captação na ala direita do Cantareira e iniciada a construção da Adutora do Guaraú (com captação dos córregos Bispo, Itaguassú e Menino); em seqüência no ano seguinte, foram canalizados na Serra da Cantareira os mananciais do Cassununga, Campo Redondo e Engordador fontes essas ligadas ao reservatório Avenida (no Largo Treze de Maio). Ainda no final do século XIX, os recursos restantes do Cantareira (ala esquerda) foram aduzidos.

Ainda no final daquele século, foram realizadas obras de emergência para utilização do Rio Tietê visando o melhor abastecimento do Belenzinho, Brás e Mooca, águas sem tratamento, causando inúmeros problemas de saúde. Em meados de 1903, enfatizou-se a captação dessas águas e, devido a estiagem de 1905 causando crise do abastecimento, no período de 1905/1907 fez-se a primeira etapa da adução do Cabuçu, para alimentação de zonas baixas da cidade: Santana, Luz, Bom Retiro e Brás; concluindo em 1911 a segunda etapa utilizando recursos do vale do Barrocada .Com nova deficiência no abastecimento, em 1910, teve início a construção da Barragem de Pedro Beicht, aproveitando manancial a oeste da Capital (ZMITROWICZ, 1984, p.60), tendo a primeira etapa dessa obra terminado em 1914, e a segunda sendo concluída no período de 1929/33, visando a regularização da vazão do Cotia. 
Também nessa época (1914), a adução do Cotia (em ante-projeto desde 1898) foi colocada em prática enviando seus recursos para o reservatório do Araçá. Dividida em duas etapas, a obra foi inaugurada em 1923 passando a reforçar o reservatório da Consolação, através da linha Jaguaré- Água Branca- Consolação.

Entre 1926-27, devido a estiagem de 1925 teve início pela Comissão de Obras Novas a adução do Rio Claro; como as obras não seguiam a contento para suprir as necessidades emergenciais da cidade, no final da década de 20, a Comissão de Saneamento da Capital começou a utilizar os recursos da Represa de Guarapiranga, encaminhados para a cidade pela adutora Santo Amaro e com destino na Estação Elevatória França Pinto. Em 1930, as obras da adutora do Rio Claro passaram para a Repartição de Águas e Esgoto sendo reiniciadas em 1932 e só finalizadas em 1939 com a construção das Estações Elevatória e de Tratamento de Água de Casa Grande e a adução desse ponto até a barragem do Poço Preto. Em 1952, essa adutora contava com a barragem do Ribeirão do Campo e com a adução das águas do Rio Guaratuba .

Dois anos depois, foi executada a derivação desse sistema para alimentar o setor Vila Alpina e outros bairros da zona Leste, integrantes do chamado "conjunto Vila Formosa", através de novas sub-adutoras e reservatórios e para as cidades do ABC, serviço desativado em 1958, quando da inauguração do novo sistema Billings.

Já o Sistema Guarapiranga, que perdeu a sua característica de fonte para geração de energia em 1958, por contrato assinado entre a Light e o Governo do Estado, passou a ser utilizado somente para abastecimento de água, sendo objeto de várias obras, executadas em etapas:

- a primeira em 1948 com a construção de algumas Estações de Tratamento, Elevatórias e reservatórios com a conseqüente expansão do serviço, reforçando a adução do Cotia (ligação com o reservatório da Mooca) e setores de abastecimento como o Jabaquara (até então, não abastecido), Avenida Paulista e Jardins;

- a segunda etapa, com a execução de nova adutora teve início em 1954, seguida da terceira adutora em 1956 e da Quarta em 1957, etapas encerradas no início da década de 60, quando o sistema assumiu o fornecimento de $52,7 \%$ do total de consumo (porcentagem da época), repassando a captação para os reservatórios da 
Vila Mariana, Vila Deodoro e Mooca e outros recém -inaugurados e expandiu a rede para algumas regiões, como por exemplo, Vilas Anastácio e Leopoldina.

Nesse mesmo período a fim de alimentar o setor da Lapa e arredores, ampliou-se o Sistema Cotia, através da construção de reservatório e torre; esse sistema, dividido em três adutoras, continuou a alimentar a linha Araçá, Água Branca e suas respectivas áreas de abastecimento além de abastecer o conjunto do IPESP no bairro do Caxingui.

Também o sistema Cabuçú, com a construção em 1954 de uma Estação de tratamento completa na região norte da cidade, pode incrementar a alimentação dos reservatórios da Mooca e de Santana.

Em 1958, o Departamento de Águas e Esgotos adquiriu o conjunto completo do Tanque Grande, constando de barragem, adutora de gravidade, estação de tratamento, reservatório e torre. Esse conjunto interligou a Estação de tratamento de Cumbica ao distrito de São Miguel, passando a alimentar pequena parte daquela região.

No período entre 1970 e 80, iniciou-se o aproveitamento dos Sistemas Juqueri e Alto Tietê, beneficiando áreas da Lapa, Santana, Freguesia do Ó, Penha e São Miguel Paulista. Em março de 1974 é inaugurado o Sistema Cantareira possibilitando o aumento no número de ligações, principalmente em bairros da zona leste e norte: Ermelino Matarazzo, Cangaíba, São Miguel Paulista, Vilas Brasilândia e Nova Cachoeirinha e, através da Estação Elevatória Santa Inês ligada ao Reservatório Águas Claras e a Estação de Tratamento de Guaraú a bairros da zona sul : Santo Amaro, Pinheiros, Vila Mariana e Pirituba. Em meados de 1977 foi terminada a duplicação do Sistema Rio Claro, expandindo a rede para Guaianazes, Itaquera, Itaim Paulista, Vilas Formosa e Alpina, Arthur Alvim, Sapopemba e parte ainda não abastecida da Mooca.

Também nessa época, enfatizou-se a captação do Sistema Cantareira, que atualmente, é o responsável pelo abastecimento de grande parte do município e cidades vizinhas, sendo o maior produtor e distribuidor de água do Sistema Integrado da Grande São Paulo. 
A captação do Cabuçú foi desativada em 1979. A partir de 1992, a utilização do Sistema Alto Tietê ganhou importância ocupando lugar de destaque na capacidade de distribuição de água potável para a grande São Paulo, sendo sua produção menos significativa somente em relação aos Sistemas Cantareira e Guarapiranga.

Atualmente a região metropolitana conta com sete sistemas de captação de água.

Como já mencionado o Cantareira é o maior deles, captando águas dos rios Jaguari, Jacareí, Cachoeira, Atibainha e Juqueri, abastecendo as zonas central e Norte e parte das zonas leste e oeste da cidade, além do Município vizinho de São Caetano do Sul.

O segundo maior produtor, o Gurapiranga capta águas da cabeceira do rio Capivari e serve as zonas Sul e Sudoeste da Capital.

O sistema Alto Tietê - o terceiro em produção - está localizado nas nascentes do rio Tietê, que são distribuídas para a zona Leste de São Paulo e para Guarulhos, Mogi das Cruzes, Mauá e Santo André.

Já os outros sistemas, colaboram com volumes bem menores. O sistema Cotia é dividido em dois setores, captando água do rio Cotia e abastecendo os municípios de Barueri, Jandira, Itapevi, Embu, Cotia e Itapecirica da Serra.

O manancial do Rio Grande é um braço da represa Billings e serve as cidades de Diadema, São Bernardo do Campo e parte de Santo André.

O Rio Claro produz volume semelhante que é direcionado ao bairro de Sapopemba em São Paulo e a Ribeirão Pires, parte de Mauá e de Santo André.

O menor dos sistemas, o Ribeirão da Estiva, abastece o pequeno Município de Rio Grande da Serra.

O esquema a seguir descreve a área de atuação dos mananciais no Município de São Paulo. 
Figura 2.4. Mananciais e principais setores de abastecimento do Município de São Paulo

\begin{tabular}{|c|l|}
\hline Manancial & \multicolumn{1}{|c|}{ Distritos abastecidos } \\
\cline { 2 - 3 } & \multicolumn{1}{|c|}{$\begin{array}{l}\text { Ermelino Matarazzo, Itaim Paulista, Itaquera, Guaianazes, } \\
\text { Iguatemi, Vila Jacuí, Vila Curuçá, Jardim Helena, São } \\
\text { Miguel Paulista, Lageado, José Bonifácio, Cidade } \\
\text { Tiradentes, Parque do Carmo }\end{array}$} \\
\hline
\end{tabular}

\begin{tabular}{|l|l|}
\hline \multirow{1}{*}{ Cantareira } & $\begin{array}{l}\text { Sé, Brás, Bela Vista, República, Jaguaré, Vila Leopoldina, } \\
\text { Lapa, Alto de Pinheiros, Barra Funda, Santa Cecília, } \\
\text { Liberdade, Perdizes, Pinheiros, Moema, Itaim Bibi, Jardim } \\
\text { Paulista, Consolação, Anhanguera, Perus, Jaguará, } \\
\text { Cachoeirinha, Tremembé, Jaçanã, Vila Medeiros, Tucuruvi, } \\
\text { Mandaqui, Jaraguá, Vila Guilherme, Vila Maria, } \\
\text { Brasilândia, Santana, São Domingos, Freguesia do Ó, } \\
\text { Pirituba, Limão, Casa Verde, Cangaíba, Ponte Rasa, Artur } \\
\text { Alvim,Cidade Líder, Parque do Carmo, São Lucas, } \\
\text { Ipiranga, Jabaquara, Cambuci, Mooca, Tatuapé, Penha, } \\
\text { Vila Carrão, Vila Formosa, Vila Matilde, Vila Prudente, } \\
\text { Aricanduva, Água Rasa, Ponte Rasa,Belém, Pari, Bom } \\
\text { Retiro }\end{array}$ \\
\hline
\end{tabular}

\begin{tabular}{|l|l|}
\hline $\begin{array}{l}\text { Rio Claro } \\
\text { Alto Tietê }\end{array}$ & São Mateus, Iguatemi, São Rafael, Sapopemba \\
\cline { 3 - 3 } &
\end{tabular}

\begin{tabular}{|c|c|}
\hline $\begin{array}{c}\text { Guarapiranga } \\
\text { Cantareira }\end{array}$ & Sacomã, Jabaquara, Jardim da Saúde, Cursino \\
\cline { 3 - 3 } &
\end{tabular}

\begin{tabular}{|c|l|l|}
\hline \multirow{3}{*}{ Guarapiranga } & $\begin{array}{l}\text { Vila Mariana, Butantã, Rio Pequeno, Raposo Tavares, Vila } \\
\text { Sônia, Itaim Bibi, Campo Belo, Campo Grande, Cidade } \\
\text { Ademar, Cidade Dutra, Santo Amaro, Morumbi, Jardim } \\
\text { Ângela, Jardim São Luís, Vila Andrade, Campo Limpo, } \\
\text { Capão Redondo, Socorro, Parelheiros, Marsillac, Grajaú, } \\
\text { Pedreira }\end{array}$ \\
\hline
\end{tabular}

Fonte: Elaboração do esquema a partir de dados do Atlas Ambiental do Município, Prodam, 2001. 
Gráfico 2.4. Captação total dos mananciais (m3/s)

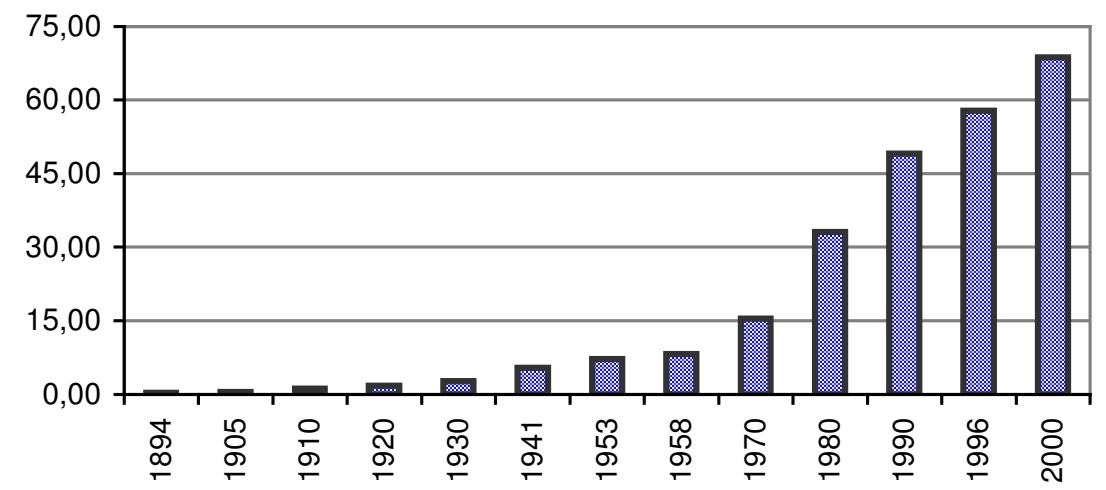

Gráfico 2.5. Evolução da captação dos principais mananciais de abastecimento de água da Grande São Paulo (m3/s) ${ }^{21}$

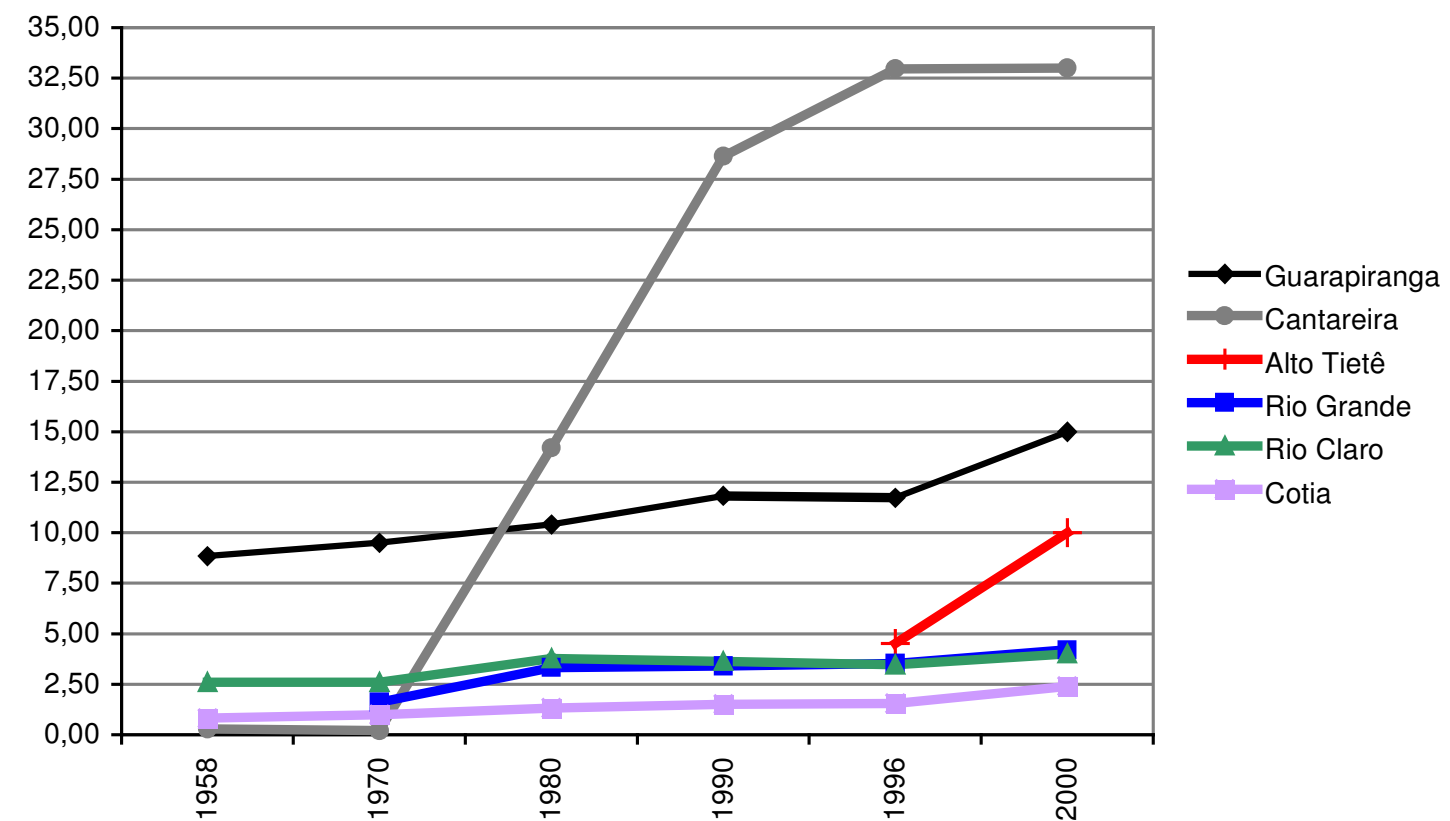

Fonte:

Dados 1894/1930:

Companhia de Saneamento Básico do Estado de São Paulo - Sabesp, Revista do D.A.E., 1958.

Whitaker, P..Cinquentenário da Repartição de Águas e Esgotos de São Paulo, Boletim Técnico R.A.E., 1943.

Dados 1941/1960:

Queiroz, V.. Abastecimento de Água na Cidade de São Paulo, Revista do D.A.E., 1964.

Dados 1970/80/90/96:

Emplasa, Sumário de Dados da Grande São Paulo, 1977/ 82 / 91 / 98.

Dado 2000:

SABESP, 2002.

21 No gráfico 2.5, que demonstra a captação por manancial foram ignorados os valores anteriores a 1958, de forma a não sobrecarregar a visualização. 
Tabela 2.3. Resumo da composição dos gráficos sobre produção e distribuição de água para a Região Metropolitana de São Paulo ${ }^{22}$

\begin{tabular}{|c|c|c|c|c|c|c|c|c|c|c|c|c|c|c|}
\hline \multirow[b]{2}{*}{ Manancial } & \multicolumn{14}{|c|}{ Vazão Diária em m3/s } \\
\hline & 1883 & 1894 & 1905 & 1910 & 1920 & 1930 & 1941 & 1953 & 1958 & 1970 & 1980 & 1990 & 1996 & 2000 \\
\hline Guarapiranga & 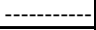 & |-------- & |------- & ב------- & \begin{tabular}{|l|}
----------- \\
\end{tabular} & 2,7 & 1,0 & 3,0 & 3,99 & 9,5 & 10,42 & 11,82 & 12,3 & 15,0 \\
\hline Rio Grande & \begin{tabular}{|l|}
$-\cdots-\cdot-\cdot---$ \\
\end{tabular} & \begin{tabular}{|l|}
$--\cdot-\cdot-\cdot---$ \\
\end{tabular} & ----------- & \begin{tabular}{ll|}
$--\cdot-\cdot-\cdot---$ \\
\end{tabular} & ------------ & ----------- & \begin{tabular}{|l|}
---------- \\
\end{tabular} & $\begin{array}{l}-\cdots--- \\
--{ }^{\prime}\end{array}$ & & 1,6 & 3,32 & 3,41 & 3,5 & 4,2 \\
\hline Rio Claro & \begin{tabular}{|l|}
$----------~$ \\
\end{tabular} & |---------- & ----------- & |---------- & |----------- & ----------- & 2,6 & 5,0 & 2,60 & 2,6 & 3,78 & 3,64 & 3,6 & 4,0 \\
\hline Alto Cotia & & & & & & & & & & 0,8 & 0,78 & 0,89 & 1,71 & 2,4 \\
\hline Baixo Cotia & --------- & --------- & ---------- & ------------ & 1,72 & & 1,0 & 0,8 & 0,81 & 0,18 & 0,53 & 0,61 & \begin{tabular}{|l|}
------- \\
\end{tabular} & $\begin{array}{l}------ \\
\end{array}$ \\
\hline Cabuçu & |----------- & |---------- & |---------- & 0,72 & & & 0,5 & 0,5 & 0,50 & 0,5 & |----------- & \begin{tabular}{|l|}
----------- \\
\end{tabular} & -------- & -------- \\
\hline Cantareira & \begin{tabular}{|r|}
0,07 \\
\end{tabular} & 0,29 & \begin{tabular}{r|}
0,44 \\
\end{tabular} & 0,44 & & & $\begin{array}{r}0,3 \\
\end{array}$ & 0,3 & 0,29 & 0,2 & 14,21 & 28,63 & 33,3 & 33,3 \\
\hline Outros & ----------- & ----------- & ----------- & ----------- & ---------- & ------------ & ----------- & \begin{tabular}{|l|}
--------- \\
\end{tabular} & & 0,05 & 0,08 & 0,09 & -------- & ------- \\
\hline Alto Tietê & --------- & ---------- & ---------- & ---------- & |----------- & ----------- & ---------- & ---------- & --------- & ---------- & ----------- & ---------- & 5,6 & 10,0 \\
\hline Total (m3/s) & 0,07 & 0,29 & 0,44 & 1,16 & 1,72 & 2,70 & 5,44 & 9,60 & 8,20 & 15,43 & 33,12 & 49,09 & 60,01 & 68,9 \\
\hline Total (I/dia)* & 6048 & 25056 & 38016 & 100224 & 148608 & 233280 & 469600 & 829200 & 708200 & 1333152 & 2861568 & 4241376 & 5184864 & 5952960 \\
\hline Tietê e Engordador & & & 0,44 & & & & & & & & & & & \\
\hline Poços Profundos & & & & & & & & & & & & & & \\
\hline Belenzinho & & ---- & ----- & ---- & ---- & 2,82 & $\cdots$ & & 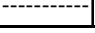 & - & ---- & --- & & \\
\hline
\end{tabular}

2.2.2.3. Distribuição: sub - adutoras, estações elevatórias e estações de tratamento $^{23}$

A lista que mencionamos a seguir, equivale a uma pequena demonstração de como a água, depois de captada chega aos setores de abastecimento da Cidade de São Paulo, por simples "distribuição em marcha" ou por armazenamento através de subadutoras chegando aos reservatórios. As primeiras sub-adutoras ligavam os mananciais captados no início do século com os reservatórios então existentes.

A partir dos anos 30, assumiram importante função na distribuição de água pela cidade as seguintes ligações:

- Mooca-Vila Mariana (dividida em algumas ramificações: Vale do Pinheiros, Anhangabaú, Pacaembu); Penha-Vila Gomes Cardim-Central do Brasil Reservatório da Penha; Moóca-Consolação;

- Mooca-Vila Deodoro; Moóca-Penha; Mooca-Sant'Anna;

- Mooca-Vila Maria; Consolação-Casa Verde, Vila América-Lapa; JabaquaraBosque da Saúde-Indianópolis-Brooklin; Água Branca-Nossa Senhora do Ó;

- linhas de gravidade Alto da Boa Vista Barão de Capanema e Alto da Boa VistaFrança Pinto;

${ }^{22}$ As lacunas em cinza, mostram os valores não localizados.

${ }^{23} \mathrm{~A}$ idéia é somente a de fornecer uma visão geral do incremento na rede ao longo dos anos, assim essa relação pode não citar todas as sub-adutoras existentes atualmente. 
- Jabaquara; Jabaquara-Sacomã; Jabaquara-Ipiranga, Vila Alpina; França PintoVila Mariana; Casa Verde; Alto da Boa Vista-Jabaquara;

- incremento de linhas de gravidade da sub-adutora Alto da Boa Vista - França Pinto;

No período 1975/1978, projeto prevendo grande expansão, interligando as zonas Leste, Norte e Sul, consolidado na década de 80 e início dos anos 90, cria as sub-adutoras: Butantã; Santana-Moóca; Reservatório Moóca (novo) -Vila DeodoroPenha; Chácara Flora-Interlagos; Ermelino Matarazzo; Guaianazes; Itaim; ItaqueraGuaianazes; Jabaquara-Moóca-São Caetano; Jaguaré; Jardim Popular; MorumbiButantã-Jaguaré-Pirajussara-Capão Redondo; Pirajussara; Pirituba; Sapopemba; Vila Brasilândia; Vila Medeiros/Vila Maria; Vila Alpina.

Além das sub-adutoras, o sistema conta com as chamadas "distribuidoras principais": Cangaíba-Ermelino; Ermelino- São Miguel; Guaraú-Jaçanã; Piritubaaguará; Vila Medeiros-Penha; Jabaquara-Sacomã; Ipiranga; Lapa-Freguesia do Ó, Consolação-Casa Verde, Vila Mascote e Vila Olímpia e outras adutoras "secundárias": Mirante-Solon; Morumbi; Solon- Reservatório da Consolação; Artur Alvim-São Miguel.

\section{Estações elevatórias}

- Guarapiranga, Bororé e Ribeirão da Estiva, Guaratuba, Santa Inês;

- Casa Verde / Vila Nova Cachoeirinha, Guaianazes; Sapopemba; Mirante, Morumbi; Jabaquara / Chácara Flora; Jardim Paulista; Jabaquara-Indianópolis; Vila América, Vila Guarani; Mooca, Vila Deodoro, Vila Alpina, Vila Mariana, Americanópolis, Vila Brasilândia, Barão de Capanema e França Pinto.

Estações de tratamento

- Casa Grande, Guaraú, Tietê, Alto e Baixo Cotia;

- Alto da Boa Vista, Theodoro Ramos, Jardim Paulista, Vila América

\subsubsection{Distribuição: reservatórios, torres e setores de abastecimento}

A topografia acidentada e de diferentes níveis, somada a extensão da cidade impôs a execução de vários reservatórios em pontos determinantes dos bairros. $\mathrm{O}$ 
primeiro reservatório da cidade foi o da Consolação, de 1883, como já mencionamos antes, recebia as águas da adutora Cantareira.

Sem data precisa, mas antes do início deste século já temos notícia do reservatório da Rua Taquari e do reservatório Avenida (antigo Liberdade) de 1896. Depois de 1900, vários reservatórios vão sendo implantados, como resumimos no quadro seguinte:

Tabela 2.4. Características dos Reservatórios e Torres no Município de São Paulo Fonte: Elaboração do esquema a partir de dados da Revista R.A.E., 1964; PMSP, 1975 e de esquema simplificado da Sabesp, 1998.

\begin{tabular}{|c|c|}
\hline Reservatório & Cap.m3 \\
\hline Água Branca - desativado & 5000 \\
\hline Americanópolis & 15000 \\
\hline Araçá & 6000 \\
\hline Araçá - antigo & 6000 \\
\hline Artur Alvim & 5000 \\
\hline Avenida - novo & 6500 \\
\hline Belenzinho & 1600 \\
\hline Brooklin & 5000 \\
\hline Butanã - zona baixa & 25000 \\
\hline Butantã - zona alta & 15000 \\
\hline Butantã - zona média & 15000 \\
\hline Cangaíba & 10000 \\
\hline Capão Redondo & 25000 \\
\hline Capela do Socorro & $5000^{*}$ \\
\hline Casa Verde (antigo) & não localizado \\
\hline Casa Verde Novo & 12000 \\
\hline Chácara Flora & 5000 \\
\hline Cidade Vargas & $5000^{*}$ \\
\hline Consolação - antigo & 19000 \\
\hline Consolação - novo & 42000 \\
\hline Curuçá & 10000 \\
\hline Edu Chaves & 25000 \\
\hline Ermelino Matarazzo & 30000 \\
\hline Freguesia do Ó & 330 \\
\hline Freguesia do Ó - novo & 8200 \\
\hline Guaianazes & 5000 \\
\hline Interlagos & 20000 \\
\hline Ipiranga & 5000 \\
\hline Itaim & 15000 \\
\hline Itaquera & 25000 \\
\hline Jabaquara & 18000 \\
\hline Jaçanã & 10000 \\
\hline Jaguaré & 20000 \\
\hline Jaraguá & 13000 \\
\hline Jardim Arpoador & $5000^{*}$ \\
\hline Jardim Popular & 10000 \\
\hline Lapa & 26000 \\
\hline Mirante & 16000 \\
\hline Mooca & 72000 \\
\hline Morumbi & 40000 \\
\hline Penha & 16000 \\
\hline Penha (antigo) - desativado & 600 \\
\hline Perus & 5000 \\
\hline Pirajussara & 10000 \\
\hline Pirituba & 25000 \\
\hline Reservatório Elevado Artur Alvim & 500 \\
\hline
\end{tabular}

\begin{tabular}{|c|c|}
\hline Reservatório & Cap.m3 \\
\hline Reservatório Elevado Avenida & 300 \\
\hline Reservatório Elevado da Moóca & 300 \\
\hline Reservatório Elevado da Penha & 300 \\
\hline Reservatório Elevado de Americanópolis & 500 \\
\hline Reservatório Elevado de Cangaíba & 500 \\
\hline Reservatório Elevado de Guaianazes & 500 \\
\hline Reservatório Elevado de Interlagos & 500 \\
\hline Reservatório Elevado de Itaquera & 500 \\
\hline Reservatório Elevado de Pirituba & 500 \\
\hline Reservatório Elevado do Butantã & 500 \\
\hline Reservatório Elevado do Butantã Zona Alta & $300^{*}$ \\
\hline Reservatório Elevado do Ipiranga & 100 \\
\hline Reservatório Elevado do Itaim & 500 \\
\hline Reservatório Elevado do Jaçanã & 500 \\
\hline Reservatório Elevado do Morumbi & 500 \\
\hline Reservatório Elevado Ermelino Matarazzo & 500 \\
\hline Reservatório Elevado Jardim Popular & 500 \\
\hline Reservatório Elevado Sacomã & $300^{*}$ \\
\hline Reservatório Elevado Sant'Anna & 450 \\
\hline Reservatório Elevado Vila Alpina & $300^{\star}$ \\
\hline Reservatório Elevado Vila Deodoro & 300 \\
\hline Reservatório Elevado Vila Maria & $300^{*}$ \\
\hline Resevatório Elevado do Capão Redondo & 500 \\
\hline Sacoman & 12000 \\
\hline Sant'Ana & 16000 \\
\hline Santo Amaro & 5000 \\
\hline São Miguel & 5000 \\
\hline Sapopemba - zona alta & 15000 \\
\hline Sapopemba - zona média & 25000 \\
\hline Shangrilla & $5000^{*}$ \\
\hline Sobras do Alto da Boa Vista & 10000 \\
\hline Taquari - desativado & 5000 \\
\hline Vila Alpina & 12000 \\
\hline Vila América & 26000 \\
\hline Vila Brasilândia & 10000 \\
\hline Vila Deodoro & 8000 \\
\hline Vila do Encontro & 11000 \\
\hline Vila Formosa & 5000 \\
\hline Vila Madalena & $5000^{*}$ \\
\hline Vila Maria & 12000 \\
\hline Vila Mariana & 5000 \\
\hline Vila Mascote & 5000 \\
\hline Vila Medeiros & 7200 \\
\hline Vila Nova Cachoeirinha & 15000 \\
\hline Vila Romana & 7500 \\
\hline Vila Santa Izabel & 5000 \\
\hline Vila Sonia & 13500 \\
\hline
\end{tabular}

Nota: Os dados com asteristicos foram estimados segundo informações de projeto (e não através de dados da inauguração). 
Gráfico 2.6. Evolução da implantação de reservatórios e torres ${ }^{24}$

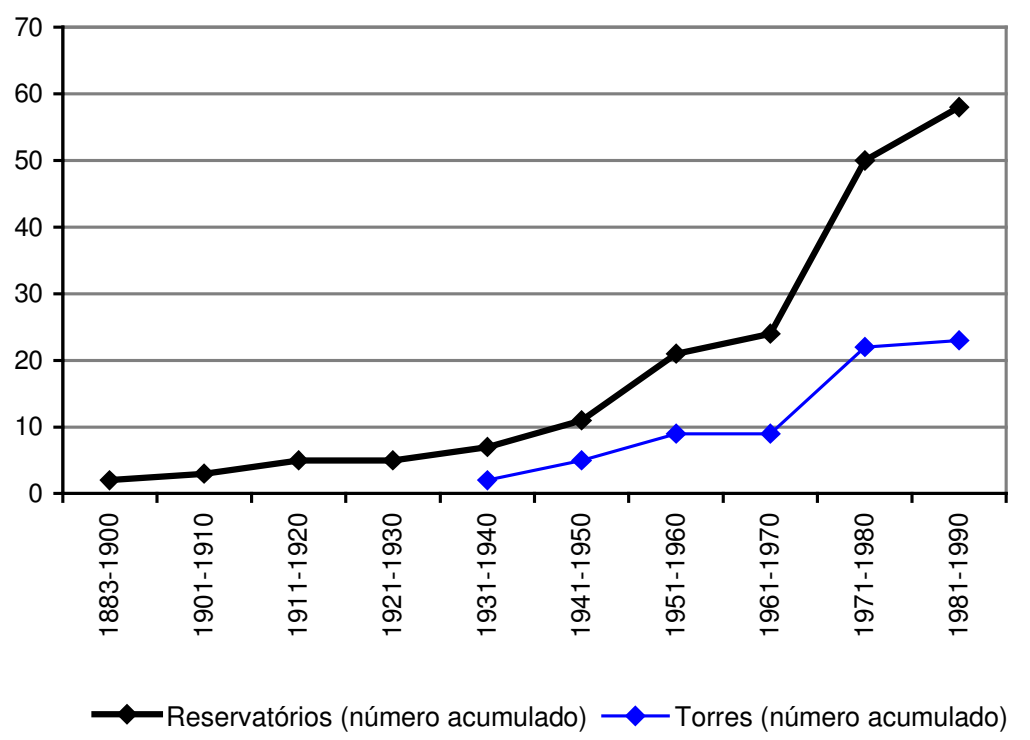

Fonte:

Dados 1883 / 1970:

Companhia de Saneamento Básico do Estado de São Paulo - Sabesp, A Evolução do Planasa em São Paulo no ano de 1975, 1976.

Santiago, F.. Quadro dos reservatórios que abastecem a cidade de São Paulo, Revista do D.A.E., 1964.

Whitaker, P. Abastecimento de água na cidade de São Paulo, Boletim Técnico R.A.E.,1946.

Dados 1971/1980:

Yassuda, E.R.. Projeto de Abastecimento de água para a região metropolitana de São Paulo 1975-78, Revista do D.A.E, 1976.

1980/ 1990:

SABESP, esquema simplificado, 1998

Tabela 2.5. Implantação e capacidade de torres e reservatórios no Município de São Paulo

\begin{tabular}{|c|c|c|c|c|}
\hline \multirow[b]{2}{*}{ Período } & \multicolumn{2}{|c|}{ RESERVATÓRIOS } & \multicolumn{2}{|c|}{ TORRES } \\
\hline & \begin{tabular}{|l|} 
Capacidade \\
Acumulada (m3)
\end{tabular} & $\begin{array}{l}\text { Número de Res. } \\
\text { Acumulado }\end{array}$ & $\begin{array}{l}\text { Capacidade } \\
\text { Acumulada (m3) }\end{array}$ & $\begin{array}{l}\text { Número de Torres } \\
\text { Acumulada }\end{array}$ \\
\hline $1883-1900$ & 25000 & \begin{tabular}{|l|}
2 \\
\end{tabular} & \begin{tabular}{|c|}
-------- \\
\end{tabular} & \begin{tabular}{|c|}
------- \\
\end{tabular} \\
\hline 1901-1910 & 31000 & 3 & -ב------- & --------- \\
\hline 1911-1920 & 46000 & 5 & ---------- & ---------- \\
\hline 1921-1930 & 46000 & 5 & -------- & 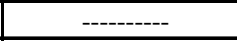 \\
\hline 1931-1940 & 126000 & 7 & 600 & 2 \\
\hline 1941-1950 & 186000 & 11 & 2250 & 5 \\
\hline 1951-1960 & 326830 & 21 & 3250 & 9 \\
\hline 1961-1970 & 335030 & 24 & 3250 & 9 \\
\hline 1971-1980 & 699730 & 50 & 9750 & 22 \\
\hline 1981-1990 & 754730 & 58 & 10250 & 23 \\
\hline 1991-1999 & & & & \\
\hline
\end{tabular}

* a capacidade dos reservatórios Vila Madalena, Cidade Vargas, Shangrilla, Arpoador, Capela do Socorro e Parque do Estado não foram consideradas, bem como para as torres Vila Maria, Sacomã e Vila Alpina foi estimada a capacidade em $300 \mathrm{~m} 3$.

${ }^{24}$ Como já mencionado, muitos dados foram estimados, pois não foi localizado junto a concessionária um relatório que apresente todas as informações. Assim preferimos omitir a década de 90 , pois neste período encontramos maior dificuldade em compatibilizar informações de várias fontes. 
Figura 2.5. Esquema simplificado da distribuição de água no Município de São Paulo Fonte: Elaboração do esquema a partir de dados da PMSP, 1975/76 e de esquema simplificado da Sabesp, 1998.

\begin{tabular}{|c|c|}
\hline Reservatórios e Torres & Distritos \\
\hline $\begin{array}{l}\text { Avenida,Vila América, Vila Deodoro, } \\
\text { Consolação }\end{array}$ & $\begin{array}{l}\text { Bom Retiro, Barra Funda, Santa Cecília, } \\
\text { Consolação, Pari, Brás, Cambuci, } \\
\text { Liberdade, Bela Vista, Sé, República }\end{array}$ \\
\hline Mooca, Vila Formosa & $\begin{array}{l}\text { Moóca, Belenzinho, Tatuapé, Água Rasa } \\
\text { Carrão, Vila Formosa }\end{array}$ \\
\hline $\begin{array}{l}\text { França Pinto (EE), Vila Mariana, } \\
\text { Jabaquara, Cidade Vargas, Vila Mascote, } \\
\text { Vila do Encontro, Parque do Estado }\end{array}$ & Moema, Vila Mariana, Saúde, Jabaquara \\
\hline Ipiranga, Sacomã & Ipiranga, Cursino, Sacomã \\
\hline Vila Madalena, Barão de Capanema (EE) & $\begin{array}{l}\text { Alto de Pinheiros, Pinheiros, Jardim } \\
\text { Paulista, Itaim Bibi }\end{array}$ \\
\hline
\end{tabular}

Butantã, Vila Sônia, Morumbi, Jardim Arpoador

Raposo Tavares, Rio Pequeno, Butantã, Vila Sônia, Morumbi

\begin{tabular}{|l|l|}
\hline $\begin{array}{l}\text { Jaguaré, Lapa, Jaraguá, Araçá, Vila } \\
\text { Romana }\end{array}$ & $\begin{array}{l}\text { Jaguaré, Vila Leopoldina, Lapa, Jaguará, } \\
\text { Perdizes }\end{array}$ \\
\hline
\end{tabular}

\begin{tabular}{|c|c|}
\hline $\begin{array}{l}\text { Chácara Flora, Alto da Boa Vista, } \\
\text { Americanópolis, Interlagos, } \\
\text { Redondo, (Santo Amaro e } \\
\text { Shangrilla, Capela do Socorro }\end{array}$ & $\begin{array}{l}\text { Marsillac, Parelheiros, Grajaú, Cidade } \\
\text { Dutra, Socorro, Santo Amaro, Campo } \\
\text { Belo, Campo Grande, Pedreira e Cidade } \\
\text { Ademar }\end{array}$ \\
\hline
\end{tabular}

\section{Pirajussara, Morumbi, Capão Redondo}

Brasilândia, Freguesia do Ó

Sapopemba, Vila Alpina

Ermelino Matarazzo, São Miguel, Itaim, Vil Curuça

Jaraguá, Pirituba, Perus, Brasilândia

Cangaíba, Penha, Artur Alvim, Jardim

Popular, Itaquera, Vila Santa Izabel

Itaquera, Guaianazes

Mirante, Santana, Vila Maria, Vila Medeiros, Nova Cachoeirinha, Edu Chaves
Jardim Ângela, Capão Redondo, Jardim São Luís, Campo Limpo, Vila Andrade

Brasilândia, Freguesia do Ó, Limão, Cachoeirinha

Vila Prudente, São Lucas, Sapopemba

Ermelino Matarazzo, Ponte Rasa, Vila Jacuí, São Miguel, Jardim Helena, Itaim, Vila Coruçá

Anhanguera, Jaraguá, Pirituba, São

Domingos, Perus,

Cangaíba, Penha, Vila Matilde, Artur Alvim

Itaquera, Lageado, Cidade Líder, São

Mateus, Parque do carmo, Iguatemi, José Bonifácio, Cidade Tiradentes,

Tremembé, Mandaqui, Tucuruvi,,

Santana, Vila Guilherme, Vila Maria, Vila Medeiros, Jaçanã 


\subsubsection{Coleta de esgotos}

\subsubsection{Evolução da distribuição territorial da rede}

Em 1883 é criado o primeiro distrito de esgotos, no bairro da Luz e implantada a usina de Ponte Pequena.

O texto a seguir reflete a situação da época: "Assim como era comum o uso de chafarizes para água antes da implantação da Repartição de Águas e Esgotos da Capital, também o era o uso de poços negros para dejetos de despejos, cujo estado sanitário, entre 1887 e 1893, chegou a níveis insuportáveis" (ANDRADE, 1966, p269). Como decorrência, no final da primeira década do século XX, grave epidemia de febre tifóide infestou a cidade. ${ }^{25}$

Na década seguinte, começa "a renovação urbana, com a reforma de edifícios e a introdução do equipamento sanitário, com início na Vila Buarque, estendendo-se pela Luz e Bom Retiro”(ANDRADE, 1966, p.272).

Um dos agravantes para a deficiência do sistema nessa época, como é descrito a seguir por SCHALCH (1939, p.16), foi o fato de não existir um plano préestabelecido para a execução da rede; "coletores atravessando quadras em diagonal, mudanças de grade sem poços de visita... e, em bairros centrais, como Santa Efigênia, Santa Cecília, Luz, Sé, Liberdade Vila Buarque, funcionando sob sistema misto, com a rede de coleta de esgotos junto com a rede de captação de águas pluviais; com conseqüências como o refluxo nas ruas pelos poços e no interior dos prédios pelos aparelhos sanitários, arrebentando canalizações..."

Em 1911 lei proíbe o uso desse sistema. As redes novas começam a ser executadas pelo "Sistema separador absoluto", estudando a bacia antes do assentamento de coletores e nunca passando a rede por terrenos particulares.

No final da década de 30, fez-se a revisão da chamada "rede velha", nos Distritos do Belém, Bela Vista, Vila Mariana, Mooca, Ipiranga, Consolação,Perdizes,

\footnotetext{
${ }^{25}$ Se compararmos a extensão da rede de coleta de esgotos e o número de ligações aos da rede de água, vamos notar que no final do século XIX e início do século XX, a expansão da rede coletora era maior do que a de abastecimento de água. Segundo MARTINS (1958, p.292), isso se deve a uma Lei provincial de 1875 , que dava preferência a instalação da rede de coleta de esgotos, dispensando a rede de água.
} 
Lapa, Brás, Jardim América, Santa Cecília, Liberdade, Santana, Cambuci, Santa Ifigênia, Bom Retiro, Sé e nos poucos pontos servidos da Penha e Butantã.

Com o remanso ${ }^{26}$ estabelecido no Rio Tietê, para colaborar na alimentação da barragem de Parnaíba e com a inversão do Rio Pinheiros, já canalizado, para a alimentação da Usina de Cubatão, a Capital ficou cercada por águas poluídas de todos os lados: Tamanduateí, Tietê, Pinheiros e Billings.

Enfatizando essa situação, Plínio Whitaker, então Diretor do D.A.E, comenta em 1950: "O mau cheiro também vae invadindo os arrabaldes desta vertente, desde Butantan até Pinheiros, Jardim Europa, Jardim América e outros...” (Revista D.A.E., 1958, n.31, p.VIII).

Em 1952/53 foi elaborado projeto relativo ao tratamento e destino de águas de esgoto e resíduos industriais na região metropolitana de São Paulo, por contrato com uma firma norte-americana.

Este projeto deu origem a Estação de Tratamento de Vila Leopoldina. A seguir no final dessa década, foram realizados estudos dividindo o Município em "distritos de esgoto", usando como limite a linha divisória de drenagem das bacias, levando em conta para o novo projeto, as características atuais e futuras dessas regiões com relação a ocupação por residências, comércio e indústrias.

Neste plano foram criados para a cidade de São Paulo, 22 áreas de controle. Este estudo também verificou as redes mistas ainda existentes, construídas no final do século XIX e elaborou um levantamento das ligações clandestinas, muito comuns em bairros, como por exemplo, o Cambuci e o Ipiranga.

Outra questão foi enfatizada pelo estudo do solo da cidade, chegando a conclusão que: "no solo argiloso e impermeável de São Paulo fossas sépticas ou fossas negras não são satisfatórias, a não ser que existam grandes áreas de infiltração". (Revista D.A.E., 1958, n.31, p.41).

Aprovado por Portaria de janeiro de 1960, esse Plano instituiu a divisão da Região Metropolitana em 6 sistemas parciais e autônomos ${ }^{27}$ :

- Vila Leopoldina, Casa Verde, Penha, Pinheiros, Santo Amaro e São Caetano.

${ }^{26}$ Mudança no regime de escoamento de um rio. 
Já na metade da década de 70 - segundo a divisão regional vigente na época ${ }^{28}$ (PMSP, 1975) - a rede era inexistente nas administrações Campo Limpo e Itaquera/Guaianazes; e muito precária em São Miguel Paulista, Pirituba/Perus, Butantã e Vila Prudente, além de ter vários pontos críticos na Freguesia do Ó, Penha, Santo Amaro, Vila Prudente, Santana e Mooca, ou seja, problemas em quase todo o Município.

Dez anos depois (SEMPLA, 1986), a situação era ainda bastante deficiente em áreas ao Norte da administração Freguesia do Ó, como o no Jardim Peri-Peri, Jardim Santa Cruz, entre outros; na regional de Santo Amaro, em locais como Campo Grande , Parelheiros e Vila Joaniza; em Itaquera/Guaianazes, onde mais da metade da região era totalmente desprovida do serviço e em São Miguel - Ermelino Matarazzo e Campo Limpo, onde praticamente $100 \%$ da área não possuía rede, no geral, áreas em grande parte ocupadas por novos conjuntos habitacionais, que acabaram dificultando o prolongamento da rede em grandes distâncias e gerando alto custo de implantação.

Atualmente, segundo afirma a Sabesp, 91\% da população é atendida, as regiões que apresentam ocupação urbana e não usufrem do serviço estão no extremo norte, beirando a região da Serra da Cantareira e em distritos como Anhanguera, e ao Sul, na região limite com as represas de Guarapiranga e Billings.

Conforme mapa da Sabesp (2000) e Prodam (2001) as regiões sul e leste tem praticamente todo o território servido. ${ }^{29}$

\footnotetext{
${ }^{27}$ Esse plano não foi totalmente concretizado. O Projeto Tietê, de 1992 a 1998, é em parte a concretização desse sistema, como veremos adiante, no item "estações de tratamento".

${ }^{28}$ Idem 20.

${ }^{29}$ Informação através de verificação do mapa digitalizado pela Sabesp (2000) e do mapa simplificado apresentado no Atlas Ambiental, produzido pela Prodam (2001). Os dados desse mapa, foram expressos neste trabalho através da figura 2.7 .
} 
Gráfico 2.7. Extensão da rede de esgotos $(\mathrm{km})$

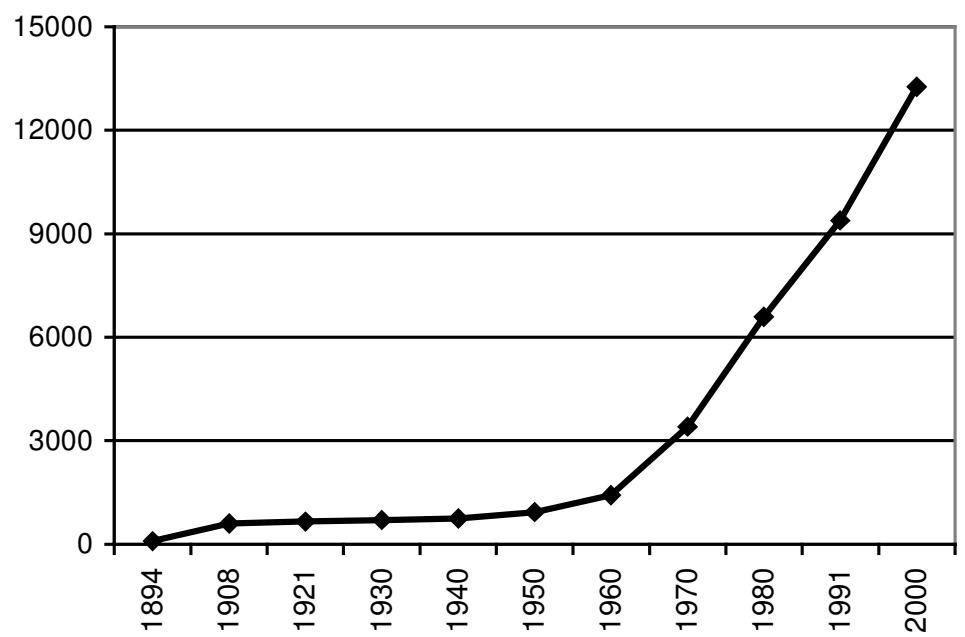

Gráfico 2.8. Evolução do número de ligações da rede de esgotos

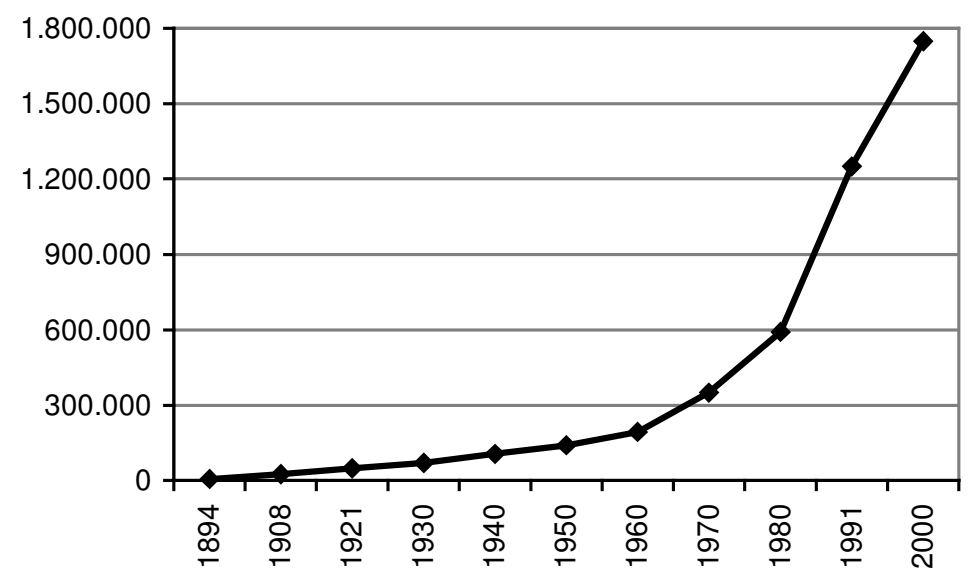

Gráfico 2.9. População atendida pela rede de esgotos versus população total do Município

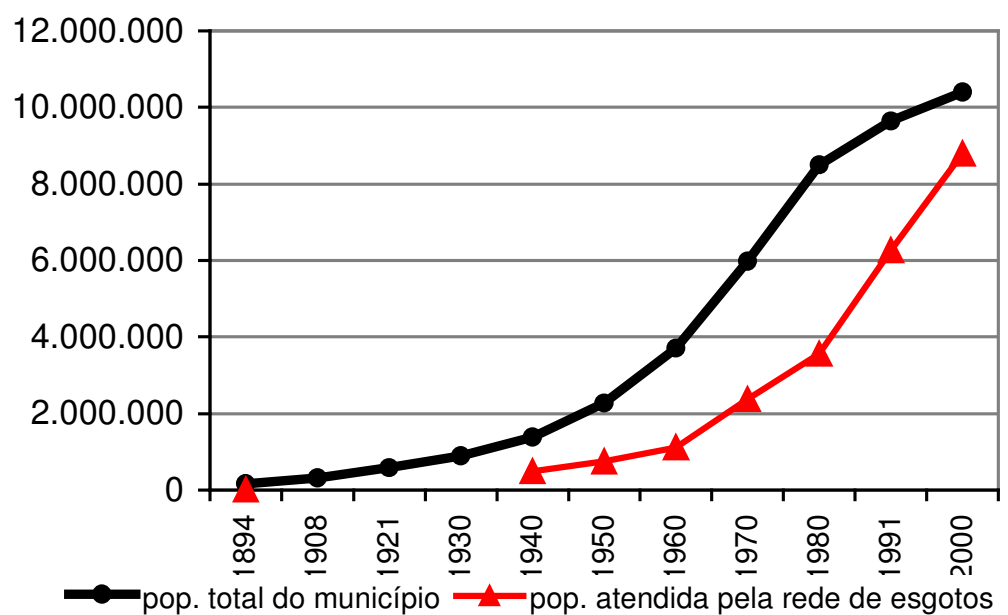


Tabela 2.6. Resumo da composição dos gráficos sobre a rede de coleta de esgotos

\begin{tabular}{|c|c|c|c|c|c|}
\hline \multirow[t]{2}{*}{ Ano } & \multirow{2}{*}{$\begin{array}{l}\text { GERAL } \\
\text { população } \\
\text { total }\end{array}$} & \multicolumn{4}{|c|}{ COLETA DE ESGOTOS } \\
\hline & & $\begin{array}{l}\text { Número Ligações à } \\
\text { Rede de esgoto }\end{array}$ & $\begin{array}{l}\text { pop. atendida pela } \\
\text { rede de esgoto }\end{array}$ & $\begin{array}{ll}\% & \text { pop. } \\
\text { Atendida }\end{array}$ & $\begin{array}{l}\text { extensão } \\
\text { da rede }\end{array}$ \\
\hline & (hab.) & & (hab.) & $(\%)$ & $(\mathrm{km})$ \\
\hline 1894 & 160.000 & 6.217 & 9.600 & 6 & 90 \\
\hline 1905 & 274.000 & 24.270 & \multicolumn{2}{|c|}{ não localizado } & 598 \\
\hline 1921 & 579.086 & 48.815 & \multicolumn{2}{|c|}{ não localizado } & 657 \\
\hline 1930 & 887.810 & 72.815 & \multicolumn{2}{|c|}{ não localizado } & 702 \\
\hline 1940 & 1.378 .539 & 106.485 & 496.274 & 36 & 755 \\
\hline 1945 & 1.696 .493 & 124.231 & 610.737 & 36 & 855 \\
\hline 1950 & 2.278 .000 & 140.267 & 751.740 & 33 & 932,5 \\
\hline 1955 & 2.916 .000 & 165.707 & 903.960 & 31 & 1.129 \\
\hline 1960 & 3.709 .274 & 194.196 & 1.112 .787 & 30 & 1.417 \\
\hline $1964 / 65$ & 4.929 .674 & 253.479 & 1.577 .485 & 32 & 2.262 \\
\hline 1970 & 5.978 .977 & 349.960 & 2.379 .632 & 39,8 & $3.410,50$ \\
\hline 1975 & 7.710 .000 & 443.524 & 2.852 .700 & 37 & 3.932 \\
\hline 1980 & 8.493 .226 & 592.371 & 3.567 .155 & 42 & 6.589 \\
\hline 1985 & 8.864 .706 & 841.140 & 3.989 .118 & 45 & 7.302 \\
\hline 1990/91 & 9.646 .185 & 1.250 .282 & 6.270 .020 & 65 & 9.382 \\
\hline 1996 & 9.839 .436 & 1.564 .137 & 7.969 .943 & 81 & 12.892 \\
\hline 2000 & 10.406 .166 & 1.747 .963 & 9.469 .611 & 91 & 13.260 \\
\hline
\end{tabular}

Fonte:

Gráficos 2.7 e 2.8

Dado 1894:

Motta, A.. Estudos Preliminares para o reforço do abastecimento d' água na cidade de São Paulo, 1911.

Dado 1908:

Azevedo, A. A cidade de São Paulo, 1958.

Dado 1921:

Emplasa, Reconstituição da memória estatística da grande São Paulo, 1993.

Dados 1930/1975:

Companhia de Saneamento Básico do Estado de São Paulo - Sabesp, Revista do D.A.E., 1976.

Dados 1980/1991:

Emplasa, Sumário de Dados da Grande São Paulo, 1982/ 91.

Dado 1996:

Emplasa, Sumário de dados, 1997.

Dado 2000:

Prefeitura do Município de São Paulo, Prodam, 2001.

Gráfico 2.9.

População Total do Município: Instituto Brasileiro de Geografia e Estatística - IBGE.

População atendida pela rede de água:

Dado 1894: Motta, A.. Estudos Preliminares para o reforço do abastecimento d' água na cidade de São Paulo, 1911; Oseki, J. H. Uncrd/Fau-Usp/Fupam, 1992.

Dado 1908: Azevedo, A. A cidade de São Paulo, 1958.

Dado 1921: Emplasa, Reconstituição da memória estatística da grande São Paulo, 1993.

Dados de 1930/1960/ 1965: Departamento de Águas e Energia Elétrica, Distribuição de Água e Coleta de Esgotos em São Paulo: afastamento e disposição de esgotos na região metropolitana, 1970.

Dados de 1970/ 1975/1985: Emplasa, Sumário de Dados da Grande São Paulo, 1977.

Dados de 1980: Secretaria Municipal de Planejamento - Sempla, Diagnóstico regionalizado do Município de São Paulo, 1983.

Dado 1991: Prefeitura do Município de São Paulo, Plano Diretor: Versão Preliminar, 1990.

Dado 1996/2000: Prefeitura do Município de São Paulo, Prodam, 2001. 


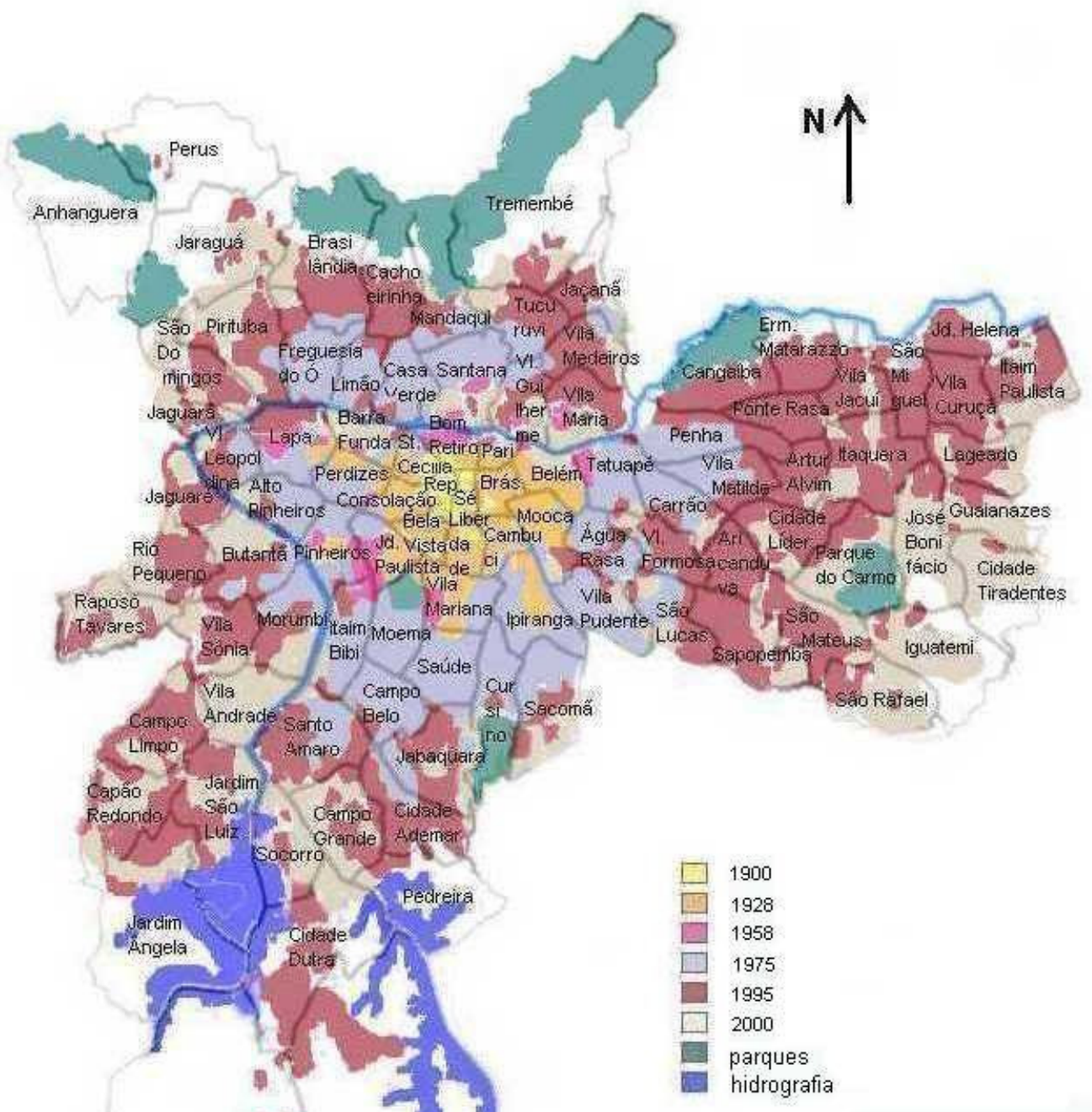

Evolução aproximada da distribuição territorial da rede de coleta de esgotos no Município de São Paulo $1900-2000$

Fonte:

Rolnik, 1997.

PMSP, 1961.

PMSP, $1975 / 76$.

SABESP, 2000.

PRODAM, 2001.

Obs.: Figura sem escala Elaboração: Massara, V.M., 2001

Figura 2.6. 


\subsubsection{Interceptores, coletores, estações elevatórias e de tratamento ${ }^{30}$}

A efetivação do tratamento dos esgotos depende das capacidades das estações mas, principalmente, da eficiência do sistema, de maneira que a implantação de equipamentos auxiliares como coletores, interceptores e elevatórias acompanhe a evolução das capacidades de tratamento.

\section{$\underline{\text { Interceptores }}$}

Para a listagem dos interceptores, devemos levar em conta a região Metropolitana. Assim, por meio de mapas, tentamos separar aqueles situados dentro do Município:

- Interceptores: Tamanduateí (ta1 e ta4) e Tietê ( ti4).

- Na região metropolitana: Perus, Caieras, Barueri, Suzano, Francisco Morato a Franco da Rocha, Tietê (ti 3, 4 e 6).

\section{Coletores}

Ênfase da construção no período de 1926, quando foram construídos os coletores da Penha e da Lapa e grande parte dos que servem as vertentes do Pinheiros.

Como parte do projeto Tietê, em 2000, foi concluído o emissário Pinheiros, evitando que 84 toneladas diárias de esgoto sejam lançados no Rio Pinheiros, sendo encaminhados para a Estação de Tratamento de Barueri.

\section{Elevatórias}

- Sistema ABC, Barueri e Suzano;

- Bom Retiro, Ponte Pequena, Avenida Pres, Wilson, Número I e II, Jaguaré, Bom Retiro, Vila Maria e Edu Chaves.

\section{Estações de tratamento}

1933: instalação experimental para tratamento de esgotos na Ponte Pequena 1937: estação experimental de tratamento de esgotos do Ipiranga (atual João Pedro de Jesus Netto)

1953: Vila Leopoldina década de 60: Pinheiros

${ }^{30}$ Estes dados se referem a informações do final da década de 80 . 


\section{7: Barueri}

data não localizada: pequenas estações: Rio Grande da Serra e Dom Duarte

década 70:Mairiporã

década de 80: Suzano, Salesópolis

1998: Sistema de Tratamento ABC, Parque Novo Mundo e São Miguel Paulista

Em 1991, somente $20 \%$ do esgoto coletado era tratado; com grande parte dos despejos recebendo somente tratamento primário, ou seja, remoção parcial dos dejetos e lançamento diretamente nos rios e córregos. Em 1994 esse número subiu para $23 \%$ e em 2001 chegou a 64\%, devido ao da primeira fase do projeto Tietê.

Esse projeto implantado no período de 1992 a 1998, além da construção do emissário Pinheiros, ampliou a extensão das redes coletoras e suas ligações, concluiu a execução de três estações de tratamento: São Miguel, ABC e Parque Novo Mundo e reformulou a estação de Barueri, ampliando expressivamente sua capacidade ${ }^{31}$.

Com a segunda fase do projeto, o objetivo é aumentar as porcentagens de coleta e de tratamento, visando a elevação da qualidade de vida, ganhos para a saúde pública, a melhoria do meio ambiente e o aumento da disponibilidade de água potável, através de projetos para reuso da água.

Hoje, estão em funcionamento quatro estações, sendo a mais importante, a Barueri, como mostram os dados numéricos a seguir.

Tabela 2.7. Resumo da composição dos gráficos sobre tratamento de esgotos ${ }^{32}$

\begin{tabular}{|c|c|c|c|c|c|c|c|c|}
\hline \multirow{2}{*}{\begin{tabular}{|lr} 
Estações & de \\
Tratamento & \\
\end{tabular}} & \multicolumn{8}{|c|}{ Vazão (m3/s) } \\
\hline & \begin{tabular}{|l|}
1937 \\
\end{tabular} & 1940 & 1958 & 1970 & \begin{tabular}{|r|}
1980 \\
\end{tabular} & 1990 & 1993 & 2000 \\
\hline Pinheiros & \begin{tabular}{|l|}
---------- \\
\end{tabular} & |---------- & & 1,64 & 1,76 & 1,46 & 1,28 & $\begin{array}{l}---- \\
--1\end{array}$ \\
\hline Ipiranga & & & 1,00 & & -------- & 0,04 & 0,04 & --------- \\
\hline Leopoldina & ----------- & |----------- & & & 1,75 & |--------- & ----------- & ----------- \\
\hline Mairiporã & |--------- & $\mid---------$ & ---------- & ---------- & 0,13 & 0,03 & 0,02 & ----------- \\
\hline Suzano & |--------- & ---------- & |--------- & |--------- & \begin{tabular}{|l|}
--------- \\
\end{tabular} & 0,33 & 0,49 & ----------- \\
\hline Salesópolis & |----------- & |----------- & ---------- & ----------- & |--------- & 0,01 & 0,01 & ----------- \\
\hline Barueri & ----------- & ----------- & ----------- & ----------- & ----------- & 3,33 & 4,29 & 9,5 \\
\hline Outros & |----------- & ----------- & ----------- & |---------- & \begin{tabular}{|l|}
---------- \\
\end{tabular} & 0,03 & 0,03 & ----------- \\
\hline São Miguel & & & & & & & & 1,5 \\
\hline $\mathrm{ABC}$ & & & & & & & & 3,0 \\
\hline Parque Novo Mundo & & & & & & & & 2,5 \\
\hline & & & & & & & & \\
\hline Total $(\mathrm{m} 3 / \mathbf{s})$ & - & - & 1,00 & 1,64 & 3,64 & 5,23 & 6,16 & 16,5 \\
\hline Total (l/dia)* & 0 & 0 & 86400 & 141696 & 314496 & 451872 & 532224 & 1425600 \\
\hline
\end{tabular}

31 Segundo reportagem do Diário oficial do ESP (25 de maio de 2002, p.112): essas estações estão trabalhando com $40 \%$ da capacidade por causa da falta de redes coletoras que transportem o esgoto para o processo de tratamento.

${ }^{32}$ As lacunas em cinza representam os valores não encontrados. 
Gráfico 2.10. Evolução total do tratamento de esgotos da Grande São Paulo (m3/s)

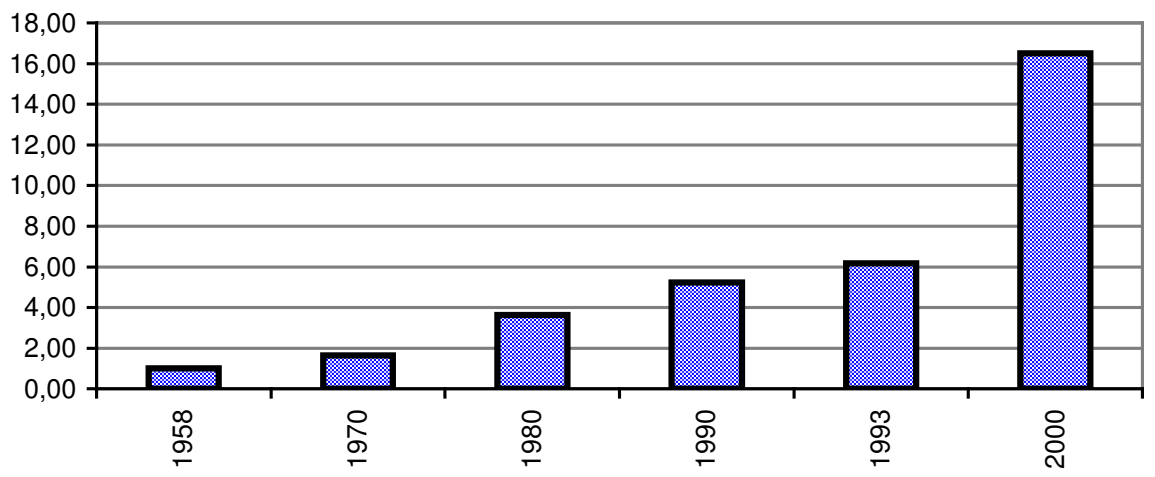

Gráfico 2.11. Evolução do volume de esgoto tratado ${ }^{33}(\mathrm{~m} 3 / \mathrm{s})$

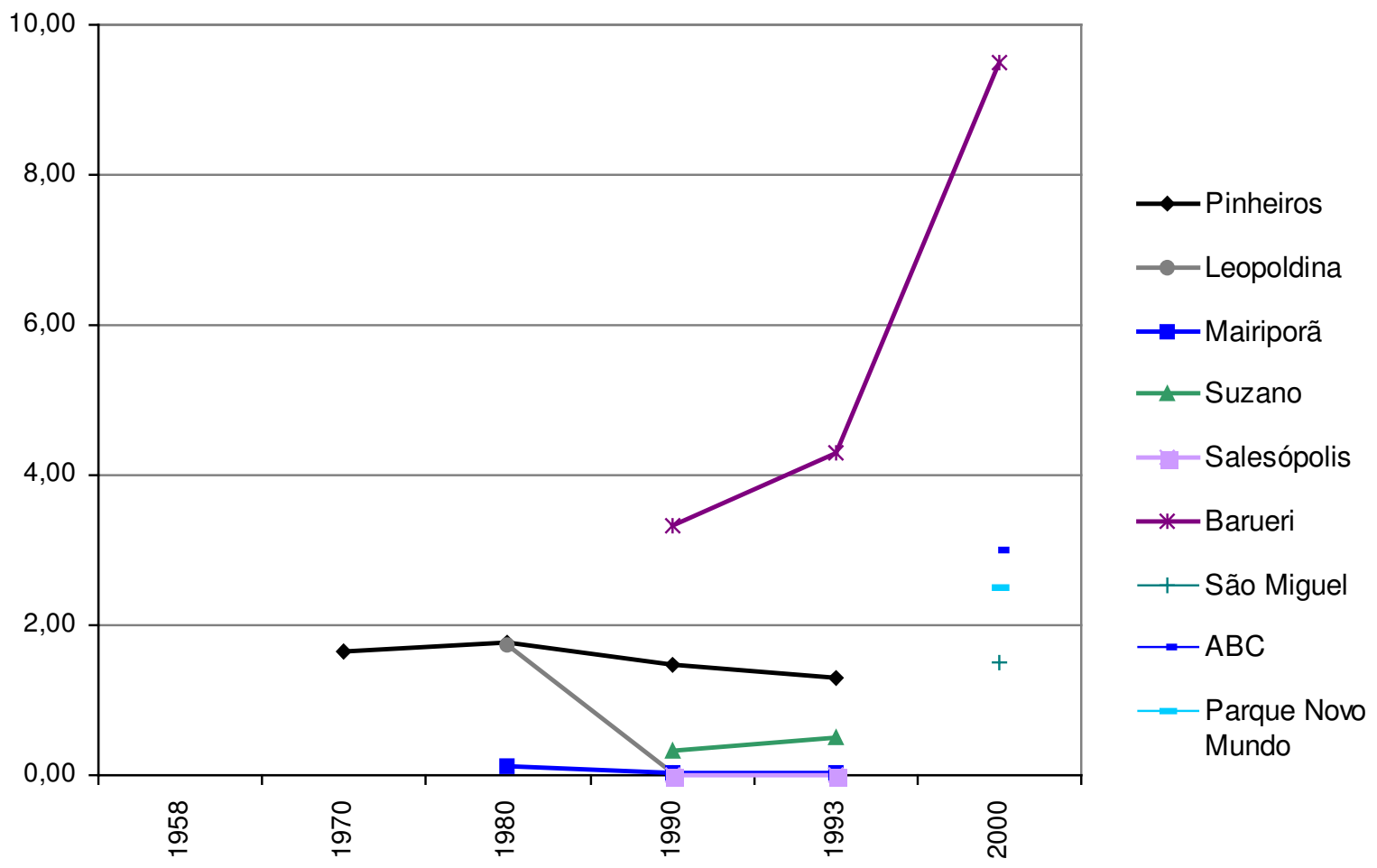

Fonte:

Dado 1958:

Companhia de Saneamento Básico do Estado de São Paulo - Sabesp, Revista do D.A.E., 1958.

Dados 1970/1993/2000:

Emplasa, Sumário de Dados da Grande São Paulo, 1977/ 82 / 91.

Dado 2000:

SABESP, 2002.

${ }^{33}$ Notar que as estações ABC, Parque Novo Mundo e São Miguel só aparecem em 2000. 
Figura 2.7. Esquema simplificado dos setores abrangidos pelas principais Estações de Tratamento de Esgotos no Município de São Paulo

\begin{tabular}{|l|l|}
\hline \multicolumn{1}{|c|}{ Distritos } & Estações de Tratamento \\
& \\
\hline $\begin{array}{l}\text { Itaim Paulista, Jardim Helena, Vila } \\
\text { Curuçá, Vila Jacuí, Itaquera, Lageado, } \\
\text { Guaianazes, Cidade Tiradentes, José } \\
\text { Bonifácio, Ermelino Matarazzo, São } \\
\text { Miguel Paulista }\end{array}$ & Sistema São Miguel \\
\hline
\end{tabular}

Ermelino Matarazzo, Cangaíba, Ponte Rasa, Tremembé, Jaçanã, Vila Medeiros, Vila Maria, Tatuapé, Água Rasa, São Lucas, Sapopemba, São Mateus, Iguatemi, Parque do Carmo, Cidade Líder, Artur Alvim, Vila Matilde, Carrão, Vila Formosa, Aricanduva, Penha, Parque São Rafael

Alto de Pinheiros, Anhanguera, Barra Funda, Bela Vista, Belém, Bom Retiro, Brás, Brasiândia, Butantã, Cachoeirinha, Campo Belo, Casa Verde, Consolação, Cursino, Freguesia do Ó, Ipiranga, Itaim Bibi, Jabaquara, Jaguara, Jaguaré, Jaraguá, Jardim Paulista, Lapa, Liberdade, Limão, Moema. Mooca, Morumbi, Pari, Perdizes, Perus, Pinheiros, Pirituba, Raposo Tavares, República, Rio Pequeno, Sacomã, Santa Cecília, Santana, Santo Amaro, São Domingos, Saúde, Sé, Tucuruvi, Vila Andrade, Vila Guilherme, Vila Leopoldina, Vila Mariana, Vila Sônia, Vila Prudente

Sapopoemba, São Lucas, Vila Prudente, Sacomã

Jardim Angela, Jardim São Luiz, Socorro Cidade Dutra, Pedreira, Cidade Adhemar, Marsillac, Parelheiros, Campo Grande, Campo Limpo, Capão Redondo, Grajaú

Fonte: Elaboração do esquema a partir de dados do Atlas Ambiental do Município, Prodam, 2001. 


\subsection{Energia}

\subsubsection{A rede de Gás}

\subsubsection{Concessão dos serviços}

A história do fornecimento de gás em São Paulo se confunde com a da iluminação Pública. No início do século XIX são feitos os primeiros ensaios para a iluminação usando azeite. Em 1847 começa a iluminação a gás hidrogênio na cidade, através de contrato entre a Câmara Municipal e Afonso Milliet (dono de uma fábrica de gás). Um pouco depois, por volta de 1862, Camilo Bourroul propôs iluminar a cidade por meio de lampiões com azeite fotogênico resinoso sem aceitação; em 1863, Francisco Taques Alvim é contratado pelo governo para executar a iluminação pública e residencial através de gás de hulha o que foi levado a vante pela Companhia The San Paulo Gas Company Ltd., em 1869, formada pelo capital de empresários ingleses; em 1870 já existiam encanamentos destinados a conduzir gás e neste mesmo ano é construída a Usina de Gás da Várzea do Carmo.

Em 1872, surgiram os primeiros lampiões, abastecidos pela "Casa das Retortas" com gás oriundo de carvão vegetal importado e são iluminadas a antiga catedral e o Palácio do Governo e nove anos mais tarde, o Jardim da Luz.

Em 1880, teve início a distribuição de gás domiciliar, somente para iluminação. Na década seguinte é construído o gasômetro da Rua da Figueira no Brás (que teve sua capacidade aumentada em 1908).

O contrato estabelecido entre essa companhia e o Governo do Estado foi renovado por trinta anos em 1897. Mas, em 1905 foram instaladas algumas lâmpadas elétricas pela "São Paulo Tramway, Light and Power Company" (de origem canadense), na Rua Barão de Itapetininga e tempos depois nas ruas do Triângulo e, em 1911 ocorre o primeiro contrato da Light com o Governo, usando o argumento que o contrato celebrado com a empresa de gás lhe dava o privilégio de explorar o serviço de iluminação a gás mas, não impedia que outro sistema fosse implantado. Durante a década de 1910, coexistiam lâmpadas elétricas e lampiões a gás, numa proporção de 864 lâmpadas para 8605 lampiões (ELETROPAULO, 1989, p.18).

A oposição da Companhia de Gás se deu por meio de requerimento aprovado para o trabalho com iluminação à eletricidade. Assim o "bico de gás incandescente" 
entrou em concorrência com as lâmpadas incandescentes de filamento de carvão até que se tornou impossível para a empresa de gás sustentar a disputa, pelo aparecimento das lâmpadas com "filamento de tungstênio estirado"; em 1912 a "Light" assume o controle acionário da San Paulo Gas Company; em 1918 o Governo autoriza o uso de gás misto (água e outra substância, como hulha, por exemplo). "A luta comercial entre a Light e a companhia de gás foi longa. Em 1929 ... foi feito um acordo incumbindo-se a Light dos serviços de iluminação, ficando o gás só com o aquecimento" (ZMITROWICZ, 1984, p. 81).

Os últimos lampiões foram desativados em $1936 .{ }^{34}$

Em síntese, a cronologia de concessão dos serviços de gás canalizado é a seguinte (considerando a iluminação a gás e o período posterior para uso residencial, comercial e industrial):

1872: The San Paulo Gas Company Ltd.

1912: controle pela São Paulo Tramway, Light and Power Company Ltd.

1929: iluminação a eletricidade contratando terceiros e distribuição de gás para uso particular assume o controle a empresa Brazilian Traction do grupo da Light 1959: é nacionalizada e se torna: Companhia paulista de Serviços de Gás 1968: passa para o controle do município e recebe o nome Companhia Municipal de Gás, autorizada a constituição de sociedade anônima

1974: mudança de nome: de Companhia Municipal de gás para Companhia de Gás de São Paulo - Comgás

1983: controle pelo governo do Estado

1984: controle passa para a estatal Cesp - Companhia Energética de São Paulo 1999: controle acionário passa para a British Gas e pela Shell.

\footnotetext{
${ }^{34}$ Mantendo a lembrança do uso de lampiões a gás, foram conservados aqueles localizados no Pátio do Colégio. Em 1995, estes lampiões foram desativados, passando por reforma dos postes e adequação para o uso do gás natural, incluindo detalhada revisão da rede subterrânea, implantada no final do século XIX, sendo reinaugurados em 2000, na ocasião do $447^{\circ}$ aniversário da Cidade.
} 


\subsubsection{Distribuição territorial da rede: uso residencial, comercial e industrial}

Uso residencial, comercial e industrial

A rede em 1900 para esse fim, era pouco desenvolvida; em 1901 aparece o primeiro fogão a gás, no Palácio do Governo.

No final da década de 20, quando as lâmpadas elétricas começaram a dominar o mercado de iluminação, a rede de gás iniciou sua expansão para o serviço de distribuição em residências para a finalidade de aquecimento, com a construção no final desse decênio de canalizações para alta pressão e do Gasômetro da Mooca. Em 1929 é celebrado contrato para a San Paulo Gas Company executar rede de fornecimento de gás.

Na década de 50, levantamento (PMSP, 1961, s.p.) mostra que pouco havia se expandido esse serviço; situação confirmada em 1968, pelo Plano Urbanístico Básico, mostrando a concentração na região central da cidade, caminhando para os Jardins e Vila Mariana.

Em 1967, a concessão de alvarás fica submetida a previsão dos construtores de instalações de gás. Em 1971 é feita a ampliação da sede da Mooca seguida da execução da Usina Massinet Sorcinelli (gás de nafta) e do Sistema para alta pressão incluindo municípios vizinhos de São Paulo.

$\mathrm{Na}$ metade da década de 70 , decreto municipal obriga que todas as construções tenham instalações de gás canalizado. Nesse período (PMSP, 1975), a rede avança um pouco mais nas direções já comentadas no período de 1950/60, e também para a Lapa e Santana, mas sem dados expressivos.

Até 1976, só existe rede por gás de nafta ainda em ferro fundido, intitulado "subsistema I" servindo comércio e residências e pequena indústria. Em 1976 é criado o chamado "subsistema II", primeiro servindo média e grande indústria e pequena quantidade de comércio.

Nos anos 80, ocorre expansão da capacidade, oriunda da exploração da Bacia de Campos.

A Secretaria Municipal de Planejamento - SEMPLA, em 1983, descreve a condição do sistema naquela época: "O gás canalizado constitui um dos serviços mais atingidos oferecido aos munícipes pela prefeitura. Atualmente o número de ligações é de aproximadamente 170.000, dos quais 160.000 são habitações 
localizadas, principalmente na região de urbanização, consolidada em torno do centro, representando cerca de $10 \%$ da demanda potencial. O restante da cidade utiliza gás liquefeito de petróleo, recebido em botijões, o qual, embora transportado por caminhões, ainda é menos oneroso para o consumidor que o gás encanado." (SEMPLA, 1983, p.16).

Em 1989 é executada a conversão a gás natural das primeiras residências na zona oeste do Município.

Na década de 90 a população atendida não passa de $8 \%$, cobrindo grande parte do centro expandido, sendo $70 \%$ do volume produzido para uso industrial, $10 \%$ para uso comercial e $20 \%$ para uso residencial.

Em 1993, a Usina Massinet Sorcinelli começa a produzir gás natural e tem início o programa de conversão em comércio e residências em larga escala (iniciado em 89).

Após a privatização em 1999, a empresa expande seus planos de abastecimento em todo o Estado de São Paulo, visando incrementar o fornecimento para usinas termelétricas e ampliar o uso em áreas industriais.

No Município, outro ponto da expansão da rede é a substituição da tubulação de ferro fundido por polietileno, suportando as maiores pressões advindas do uso de gás natural, iniciada na região central da cidade (a rede mais antiga).

Como meta de ampliação até 2003, estão incluídas a extensão da rede ao Sul, até Santo Amaro, ao Norte, até Santana e a oeste até a Lapa.

Segundo o presidente da Companhia Oscar Alfredo Prieto, em entrevista de 1999: “o potencial de crescimento é enorme, mas somente será atingido quando convencermos os consumidores de que o uso do gás é vantajoso em relação a outras fontes, como o diesel e a eletricidade" (RODRIGUEZ; ESP, 1999, s.p.); fator que ganha importância face a atual crise energética e que está direcionando os novos rumos de expansão da rede, através da criação do programa de co-geração de energia, implantado desde 2001 na Usina de Piratininga, permitindo a produção simultânea de energia elétrica, térmica e de vapor através do gás natural.

Também a utilização de aquecedores a gás, para o uso residencial na calefação, produção de água quente e lareiras, vem incrementando o uso de gás canalizado na região central da cidade. 
Já, os estabelecimentos comerciais devem respeitar a legislação e executar obrigatoriamente ligações a gás e sendo a rede existente, utilizar o gás natural.

No caso de indústrias, principalmente dos ramos petroquímico, siderúrgico, vidro, papel, cerâmicas, bebida e alumínio o consumo vem aumentando, com a verificação prévia pela Comgás da rede externa existente e sua distância até a entrada da indústria.

As informações a seguir correspondem ao período anterior a privatização e visam caracterizar a evolução do consumo de gás no município em função do tipo de consumidor e também a evolução do consumo de gás natural. ${ }^{35}$

Gráfico 2.12. Variação do consumo de gás de nafta por tipo de consumidor (\%)
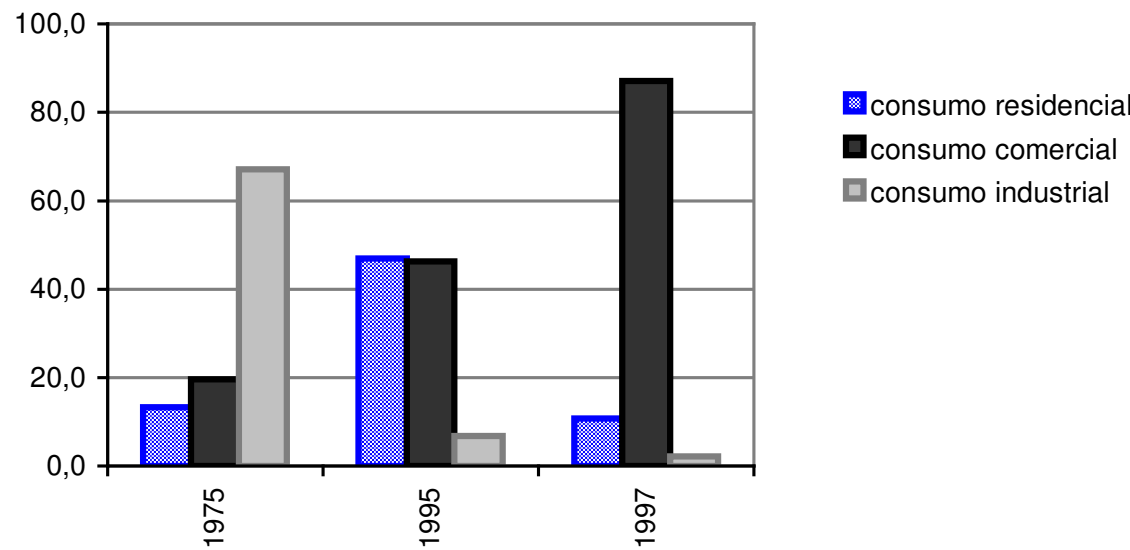

Fonte: Companhia Energética de São Paulo, 1995 / 97

Tabela 2.8. Resumo da composição dos gráficos sobre a utilização de gás de nafta no Município de São Paulo

\footnotetext{
${ }^{35}$ Não localizamos dados sobre a evolução da rede em quilômetros e avanço da população atendida que proporcionassem uma visualização contínua da expansão desse serviço; a maioria das informações se refere ao Estado de São Paulo e impossibilita a separação para a cidade.
} 
Gás de Nafta

\begin{tabular}{|l|r|r|r|r|r|r|}
\hline \multirow{2}{*}{ Tipo Uso } & \multicolumn{2}{|c|}{1975} & \multicolumn{2}{c|}{1995} & \multicolumn{1}{c|}{1997} \\
\cline { 2 - 7 } & Volume $(\mathrm{m} 3)$ & \multicolumn{1}{c|}{$\%$} & Volume $(\mathrm{m} 3)$ & \multicolumn{1}{c|}{$\%$} & Volume $(\mathrm{m} 3)$ & \multicolumn{1}{c|}{$\%$} \\
\hline res & 2.008 .482 & 13,3 & 524.970 & 46,9 & 1.313 & 10,7 \\
\hline com & 2.970 .818 & 19,6 & 518.626 & 46,3 & 10.652 & 87,1 \\
\hline ind & 10.149 .859 & 67,1 & 75860 & 6,8 & 265 & 2,2 \\
\hline total & $\mathbf{1 5 . 1 2 9 . 1 5 9}$ & 100 & $\mathbf{1 . 1 1 9 . 4 5 6}$ & 100 & $\mathbf{1 2 . 2 3 0}$ & 100 \\
\hline
\end{tabular}

Gráfico 2.13. Variação do consumo de gás natural por tipo de consumidor (\%)

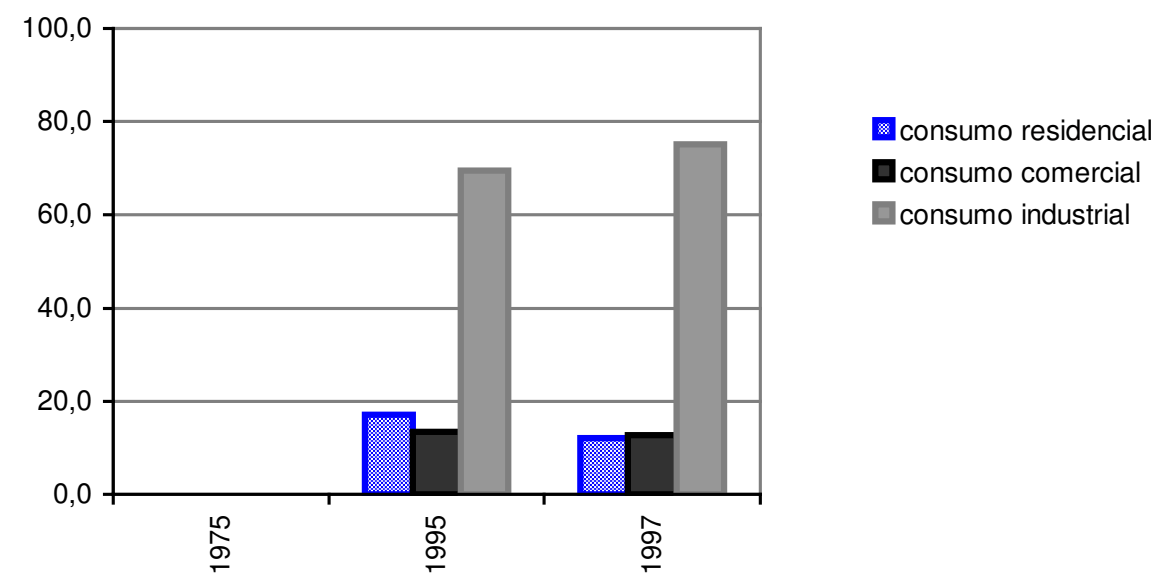

Fonte: Companhia Energética de São Paulo, 1995 / 97

Tabela 2.9. Resumo da composição dos gráficos sobre a utilização de gás natural no Município de São Paulo

Gas Natural

\begin{tabular}{|l|r|r|r|r|}
\hline \multirow{2}{*}{ Tipo Uso } & \multicolumn{2}{|c|}{1995} & \multicolumn{2}{c|}{1997} \\
\cline { 2 - 5 } Volume $(\mathrm{m} 3)$ & \multicolumn{1}{c|}{$\%$} & Volume $(\mathrm{m} 3)$ & \multicolumn{1}{c|}{$\%$} \\
\hline res & 1.309 .146 & 12,0 & 2.128 .404 & 17,1 \\
\hline com & 1.396 .353 & 12,8 & 1.677 .545 & 13,5 \\
\hline ind & 8.212 .033 & 75,2 & 8.625 .562 & 69,4 \\
\hline total & $\mathbf{1 0 . 9 1 7 . 5 3 2}$ & 100 & $\mathbf{1 2 . 4 3 1 . 5 1 1}$ & 100 \\
\hline
\end{tabular}

A seguir, focalizamos 3 momentos da expansão da rede de gás canalizado no Município, lembrando que em 1999 é considerado o projeto de expansão até $2003 .{ }^{36}$

\footnotetext{
${ }^{36}$ Em contato com a Comgás, fomos informados que a rede atual será digitalizada neste ano e que não existe informações anteriores que pudessem ser utilizadas para a elaboração do esquema a seguir, embora haja um acervo completo de detalhe de obras e reparos na rede, totalizando mais de 600 pranchas. Assim a distribuição territorial apresenta mancha genérica para o ano de 2003, elaborada através da interpretação de texto descrevendo a condição da rede por reportagem de Rodriguez, 1999.
} 


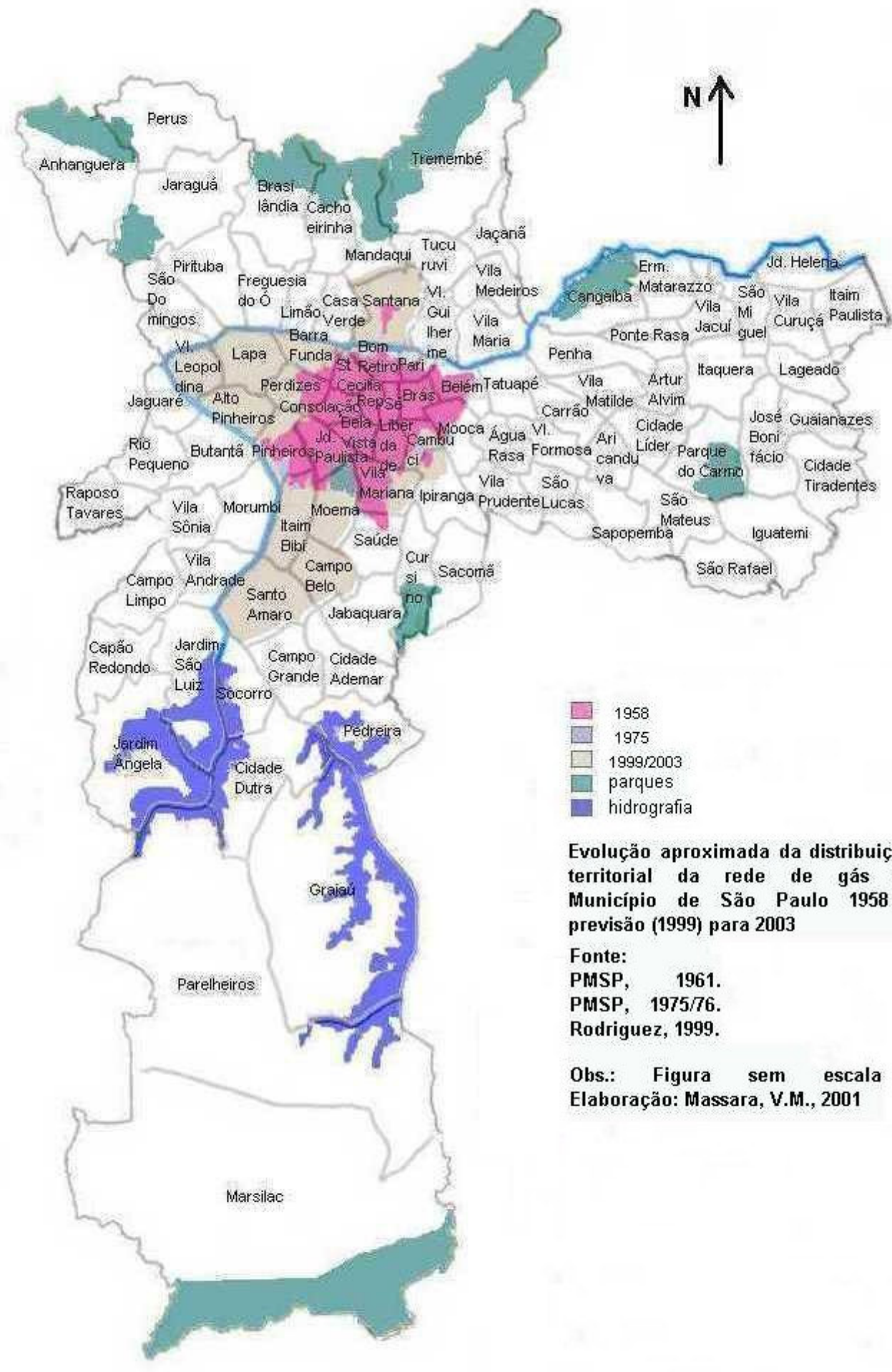

Figura 2.8. 


\subsubsection{Energia elétrica}

\subsubsection{Concessão dos serviços}

A primeira experiência com lâmpadas elétricas foi realizada em 1868, pelo Frei Germano d'Anneay. A seguir, no início da penúltima década do século XIX, Diogo Antônio de Barros fez a iluminação de uma residência na rua Florêncio de Abreu. Na mesma década foram utilizadas lâmpadas a arco voltaico na Rua Boa Vista. Mas, o serviço de iluminação elétrica só ganhou ênfase no século XX: "Em 1900, a Companhia de Água e Luz do Estado de São Paulo ${ }^{37}$ fornecia energia elétrica do escurecer até a meia-noite, as zona centrais e comerciais da cidade, fazendo concorrência com o gás" (ELETROPAULO, 1989, p. 15). No ano seguinte foi iniciada a abertura de canais subterrâneos para distribuição de energia, que até então era feita por via aérea através de postes de madeira; a Usina de Vila Buarque é ativada e seu "ronco ensurdecedor" desvaloriza os lotes da redondeza.

Quatro anos mais tarde, em 1905, foi iluminada a Rua Barão de Itapetininga e em 1907, as ruas do Triângulo (São Bento, Direita e Quinze de Novembro).

Em 1911 foi assinado o primeiro contrato da Light (The São Paulo Railway, Light and Power Company Limited) com o Governo do Estado e a simultânea iluminação da Esplanada do Teatro Municipal. Esse contrato tinha como compromisso iluminar por 10 anos as Avenidas Higienópolis e Brig. Luís Antônio, a Estrada da Penha (atual Celso Garcia), os bairros da Penha, Água Branca, e algumas ruas da Lapa, além do reforço da Av. Paulista e da Rua da Consolação. Em 1912, foram acrescidas as ruas dos Campos Elíseos, Santa Efigênia, e Liberdade, a área comercial e a Av. Tiradentes. Um ano depois, a rede se expandiu para algumas ruas do Ipiranga e reforço das ruas Domingos de Moraes e Vergueiro.

Em 1917, a cidade contava com aproximadamente 55000 lâmpadas (para iluminação pública): “de todos os serviços públicos o da iluminação foi o único que teve ampliação compatível com o aumento da população.” (ELETROPAULO, 1989, p.18).

\footnotetext{
${ }^{37}$ Não foi localizada maiores informações sobre o histórico dessa empresa.
} 
Na década de 20 foram ativadas as oficinas do Cambuci, que com o passar dos anos substituíram a importação de peças, torres, postes e transformadores vindos da Europa.

Em síntese, a cronologia de concessão dos serviços de energia elétrica e iluminação publica é a seguinte:

1886: fundada a Empresa Paulista de Eletricidade subordinada a firma Marques Moutte \& Comp. Geradores Elétricos

1880: é sucedida pela Companhia de Água e Luz do Estado de São Paulo 1899: The San Paulo Tramway, Light and Power Co. Ltda. pela transferência da concessão dada a Francisco Antônio Gualco e Antonio Augusto de Souza

1912: as empresas passam a ser controladas pela holding Brazilian Traction Light and Power Co. Ltd.

1947: todas as empresas da Light passam a ser administradas pela Cobast Companhia Brasileira Administradora de Serviços Técnicos

1956: passa para o controle da empresa Brascan Limited

1979: o governo através da Eletrobrás assume o Controle acionário da então Light Serviços

1981: o governo do Estado adquire da Eletrobrás o subsistema paulista da Light criando a Eletropaulo - Eletricidade de São Paulo S.A.

1997: privatização, dando origem em dezembro de 97 a quatro empresas:

- EBE Empresa Bandeirante de Energia

- EPTE Empresa Paulista de Transmissão de Energia Elétrica S.A.

- EMAE Empresa Metropolitana de Águas e Energia S.A.

- Eletropaulo Metropolitana - Eletricidade de São Paulo

A EMAE coube a parte de "eletricidade", ou seja, a utilização de recursos para a geração de energia que depois é distribuída entre outros, aos 24 municípios da grande São Paulo que fazem parte da área de concessão da Eletropaulo, a qual ficou destinada a distribuição de energia.

1998: a Eletropaulo é adquirida em Leilão pela Lightgás, subsidiária do grupo Light (empresa americana), pela francesa Electricité de France e pela empresa brasileira CSN. 
Em 2001, com a venda das ações da CSN e da americana Reliant Energy, a Eletropaulo passou a ser controlada pelo grupo norte-americano AES Corporation.

No Município para melhor controle dos sistemas de distribuição de energia, em 2001, a cidade foi dividida em 11 unidades administrativas ${ }^{38}$ :

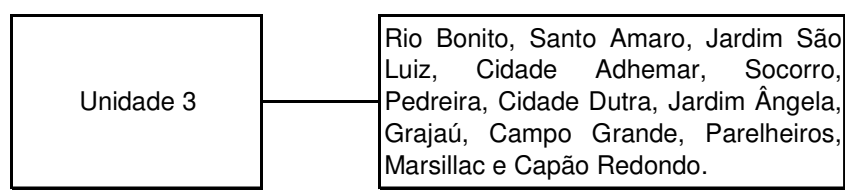

\begin{tabular}{|c|c|}
\hline Unidade 5 & $\begin{array}{l}\text { Butantã, Jaguaré, Vila Leopoldina, } \\
\text { Lapa, Barra Funda, Perdizes, Pinheiros, } \\
\text { Alto de Pinheiros, Rio Pequeno, Vila } \\
\text { Sônia, Morumbi, Raposo Tavares, Vila } \\
\text { Andrade, Campo Limpo, Capão } \\
\text { Redondo, Jardim Paulista. }\end{array}$ \\
\hline Unidade 6 & \begin{tabular}{|l} 
Pirituba, \\
Bnhanguera,
\end{tabular} \\
\hline
\end{tabular}

\begin{tabular}{|l|l|}
\hline \multirow{2}{*}{ Unidade 7} & $\begin{array}{l}\text { Tucuruvi, Cachoeirinha, Tremembé, } \\
\text { Jaçanã, Mandaqui, Vila Medeiros, } \\
\text { Santana, Vila Guilherme, Vila Maria. }\end{array}$ \\
\cline { 2 - 3 } & \\
\cline { 2 - 3 } & $\begin{array}{l}\text { Unidade 8 } \\
\text { Maranga, Liberdade, Cambuci, Vila } \\
\text { Moema. Cursino, Sacomã, Saúde, }\end{array}$ \\
\hline
\end{tabular}

\begin{tabular}{|c|c|}
\hline Unidade 9 & $\begin{array}{l}\text { Santa Cecília, Bom Retiro, Consolação, } \\
\text { Sé, República, Bela Vista, Liberdade, } \\
\text { Barra Funda, Jardim Paulista. }\end{array}$ \\
\hline Unidade 10 & $\begin{array}{l}\text { Itaim Bibi, Jardim Paulista, Moema, } \\
\text { Saúde, Campo Belo, Jabaquara. }\end{array}$ \\
\hline Unidade 11 & $\begin{array}{l}\text { Vila Prudente, Vila Formosa, } \\
\text { Aricanduva, Cidade Líder, São Lucas, } \\
\text { Água Rasa, Artur Alvim, Sapopemba. }\end{array}$ \\
\hline Unidade 12 & $\begin{array}{l}\text { Penha, Pari, Brás, Mooca, Belém, } \\
\text { Água Rasa, Tatuapé, Carrão, Vila } \\
\text { Formosa, Vila Matilde, Cangaíba, Artur } \\
\text { Alvim. }\end{array}$ \\
\hline
\end{tabular}

\begin{tabular}{|l|l|}
\hline Unidade 13 & $\begin{array}{l}\text { São Miguel Paulista, Ponte Rasa, } \\
\text { Ermelino Matarazzo, Vila Jacuí, Vila } \\
\text { Curuçá, Itaim Paulista, Jardim Helena, } \\
\text { Itaquera. }\end{array}$ \\
\hline
\end{tabular}

\begin{tabular}{|l|l|}
\hline \multirow{2}{*}{ Unidade 14 } & $\begin{array}{l}\text { São Mateus, Itaquera, Lageado, } \\
\text { Guaianazes, Parque do Carmo, José } \\
\text { Bonifácio, Cidade Tiradentes, Iguatemi, } \\
\text { São Rafael. }\end{array}$ \\
\hline
\end{tabular}

Figura 2.9. Setores administrativos da Eletropaulo no Município de São Paulo. Fonte: Fonte: Elaboração do esquema a partir de dados da Eletropaulo, 2000.

${ }^{38}$ Levando em conta outros municípios próximos a São Paulo, a área de concessão da Eletropaulo é dividida em 14 setores, representados pelas unidades 1,2 e 4. 
Para determinação dos distritos que formariam cada unidade, foram levados em conta dois aspectos: densidade demográfica e área em cada bairro servida por sistema subterrâneo (já que esse sistema cria maiores dificuldades de manutenção quando comparado ao aéreo).

\section{$\underline{\text { O serviço de iluminação pública no Município de São Paulo }}{ }^{39}$}

Em 1969, houve uma modificação na administração do serviço de iluminação pública do município. Através de contrato entre a antiga Light e a Prefeitura, ficou decidido que a primeira arcaria com a mão de obra para manutenção da rede existente e para sua ampliação e a segunda, com o gerenciamento e fornecimento de material.

Em 1989 houve nova modificação, mantendo a manutenção da rede sob responsabilidade da Eletropaulo mas passando a instalação de novos pontos para o Ilume.

Em 2000, com o término do contrato de 30 anos e com a nova organização da Eletropaulo, o Ilume assumiu todos os serviços (manutenção, ampliação e gerenciamento), ficando a cargo da concessionária, apenas a rede subterrânea da área central da cidade, assim como o fornecimento de energia e a sua transformação de alta para baixa tensão.

\subsubsection{Distribuição territorial da rede: iluminação pública e uso privado}

\section{Iluminação pública}

Em 1927 era considerada a seguinte distribuição dos postes: "Dois braços são mais alongados: um atravessa a Moóca, Belenzinho, Tatuapé e acompanha, a leste, a linha da Estrada de Ferro Central do Brasil, o segundo prolonga-se para noroeste...seguindo para Norte até Santana, para o sul pelas Vilas Mariana e Clementino até o Cambuci e Ipiranga; a leste até a Penha, a oeste até a Lapa e alto da Lapa, chegando até a região dos Jardins.” (ELETROPAULO, 1989, p.25).

Em 1929, outro contrato com o governo assegura o monopólio de iluminação pública na capital para a Light. A partir de então, as luminárias associam aspectos técnicos, financeiros e estéticos, funcionando como "mobiliário urbano"; são 
elaborados diversos tipos de acordo com a área de implantação: ruas elegantes, ruas de comércio, bairros operários, assim como a variação da intensidade luminosa: maior quanto mais importante fosse o logradouro.

Avançando para o período 1950/60, segundo mapeamento da Prefeitura (PMSP, 1961, s.p.), a rede se concentrava nas regiões de Pinheiros, Lapa e por todo o Centro, existindo também em parte da Zona Norte e partes da Mooca, Penha, Vila Mariana e Ipiranga.

Durante a década de 70, havia grande deficiência nesse serviço, localizandose por quase todo o Município. Segundo a divisão pela prefeitura em Administrações Regionais vigente naquela época ${ }^{40}$, áreas como o Butantã, Freguesia do Ó, São Miguel Paulista / Ermelino Matarazzo, Vila Prudente, Itaquera / Guaianazes, Pirituba / Perus, Santana, Santo Amaro e Campo Limpo só possuíam iluminação em vias de grande movimento e maior adensamento.

Essa situação teve significativa melhora nos anos 80 , quando o déficit caiu de 55\% em 1980 para 15\% em 1982, concentrados em regiões do Sul e Leste do Município (PMSP; SEMPLA, 1983, p.15).

O mapa de 1997, representando pontos com pedidos de ligação ou manutenção, apresenta várias regiões da cidade com grande densidade de solicitações. As áreas com maior déficit estão na região da Freguesia do Ó e arredores, como a Vila Nova Cachoeirinha, Casa Verde e Limão na região Norte; Cangaíba, Ponte Rasa e parte da Penha, Vila Prudente, Sapopemba, São Lucas e São Mateus na zona Leste; Cidade Adhemar, Campo Grande, Jardim Ângela e Cidade Dutra; na zona sul e na área central, arredores do distrito da Sé.

Como esse esquema apenas demonstra o registro de pedidos oficiais, pode não traduzir verdadeiramente áreas com problema, como verificamos no extremo leste, por ocasião da visita descrita no capítulo 4.

A Diretoria Técnica do Departamento de Iluminação Pública - Ilume, afirma que 4\% da área do Município continua sem iluminação pública e que o acelerado crescimento periférico dificulta a cobertura total. A cada ano, 20 mil pontos de luz são instalados na cidade. Além da ampliação da rede, a manutenção corretiva estima

${ }^{39}$ Informação obtida através de entrevista com a Divisão de ampliação dos serviços ILUME I. 
trocar aproximadamente 10 mil lâmpadas por mês e através da manutenção preventiva, em convênio com o Governo Federal, está sendo implantada a troca de lâmpadas de mercúrio por sódio, visando menor consumo de energia e revisão da antiga rede, tendo essa deficiência de iluminação se estendido mesmo a alguns bairros nobres.

De forma geral, a expansão periférica e problemas com a rede instalada a várias décadas, são os principais itens de verificação do serviço, tornando complexo o pleno atendimento.

\section{$\underline{\text { Uso privado }}$}

A rede de distribuição subterrrânea ${ }^{41}$ no centro de São Paulo começou a ser implantada no início do século XX. A primeira estação distribuidora foi a Paula Souza, no centro da cidade. A partir de 1908 com a criação de outras estações na Lapa, bairros mais distantes começaram a ser atendidos, principalmente em função do uso industrial dessas áreas.

Na década de 20, além do incremento da rede com a construção de várias subestações e câmaras subterrâneas para transformadores, foi construído um anel periférico, que fechava o sistema "net-work" (sistema reticulado de distribuição de energia). "Com o desenvolvimento espetacular da cidade, essa rede foi sendo rapidamente ampliada, e em 1951 sofreu uma nova grande transformação, com a instalação do novo net-work. Toda rede de distribuição passou por uma completa remodelação; de janeiro de 1951, há por exemplo a notícia da instalação de uma linha de transmissão subterrânea, da sub-estação do Braz para o centro da cidade, pioneira no Brasil no gênero." (TELLES, 1984, vol.2, p.416).

Por outro lado, certos autores criticam o fato do serviço ser ineficiente em várias áreas da cidade nessa mesma época. Segundo BRANCO (1951, p.13): "as deficiências do serviço podem ser também aferidas pelo número de prédios privados da iluminação domiciliar no município de São Paulo. Em dezembro de 1949, excluindo Santo Amaro, o município contava cerca de 15000 prédios privados de luz

\footnotetext{
${ }^{40}$ Ibidem 20.

${ }^{41}$ Antes o serviço era constituído apenas pela rede aérea (TELLES, 1984, v.2; ELETROPAULO, 1989).
} 
na zona urbana e suburbana e cerca de 40000 prédios nas mesmas condições na zona rural."

Dados do Censo Predial realizado em 1970 pelo IBGE, apontam que as maiores deficiências no tocante a "número de prédios por instalações existentes", se localizavam nas zonas sul, leste 2 e rural. $^{42}$

O relatório da SEMPLA de 1983, afirma que a rede atendia a 94\% da população naquela data.

Contudo, esse parece ser o sistema que melhor tem atendido a população ao longo dos anos, acompanhando quase sempre a evolução da mancha urbana.

Dados da concessionária dos anos de 2000/01 estimam que a rede do Município possui 1,6 mil quilômetros de circuito em linhas de subtransmissão, 311 mil quilômetros de condutores aéreos e 10 mil quilômetros de condutores subterrâneos.

Também como a Sabesp, a Eletropaulo está desenvolvendo um programa de uso racional da energia e controle de desperdícios. No campo da gestão e análise do sistema, está informatizando dados sobre as redes e linhas de transmissão, visando melhor desempenho e maior rapidez na manutenção, assim como o estudo de áreas densamente ocupadas.

Um dado interessante fornecido pela EMPLASA $(1977 ; 1986)$ e pela PRODAM (2000) é apresentado no gráfico a seguir, que expressa a variação no consumo de energia por tipo de uso em um período de 23 anos.

Podemos notar a expressiva queda do consumo industrial que é substituído em parte pelo consumo comercial e de prestação de serviços e em parte pelo uso residencial, evidenciando as modificações econômicas ocorridas no país nesse período, como a diminuição de incentivos as indústrias paulistanas e o processo de globalização.

${ }^{42}$ O IBGE considerou nesse Censo Predial de 1970 como região Sul os distritos de Santo Amaro, Jabaquara, Socorro e Ibirapuera; como Leste 2, São Miguel Paulista, Itaquera e Guaianazes e como área rural Perus, Jaraguá e Parelheiros. 
Tabela 2.10. Porcentagem de consumo de energia elétrica no Município de São Paulo por tipo de uso

\begin{tabular}{|l|r|r|r|r|r|r|}
\hline \multirow{2}{*}{ Tipo de Uso } & \multicolumn{7}{|c|}{ Porcentagem segundo tipo de uso } \\
\cline { 2 - 7 } & \multicolumn{1}{|c|}{1975} & 1980 & 1985 & 1990 & 1995 & 1998 \\
\hline Residencial & 27,5 & 30,5 & 27,0 & 32,7 & 34,6 & 38,6 \\
\hline Industrial & 20,5 & 40,8 & 43,8 & 33,6 & 23,5 & 21,4 \\
\hline Comercial/Serviços & 42,3 & 18,3 & 17,7 & 21 & 29,7 & 28,0 \\
\hline $\begin{array}{l}\text { Outros (iluminação } \\
\text { pública, consumo } \\
\text { próprio) }\end{array}$ & 9,7 & 10,4 & 11,5 & 12,7 & 12,2 & 12,0 \\
\hline
\end{tabular}

Gráfico 2.14.Variação do consumo de energia elétrica no Município por tipo de consumidor $(\%)$

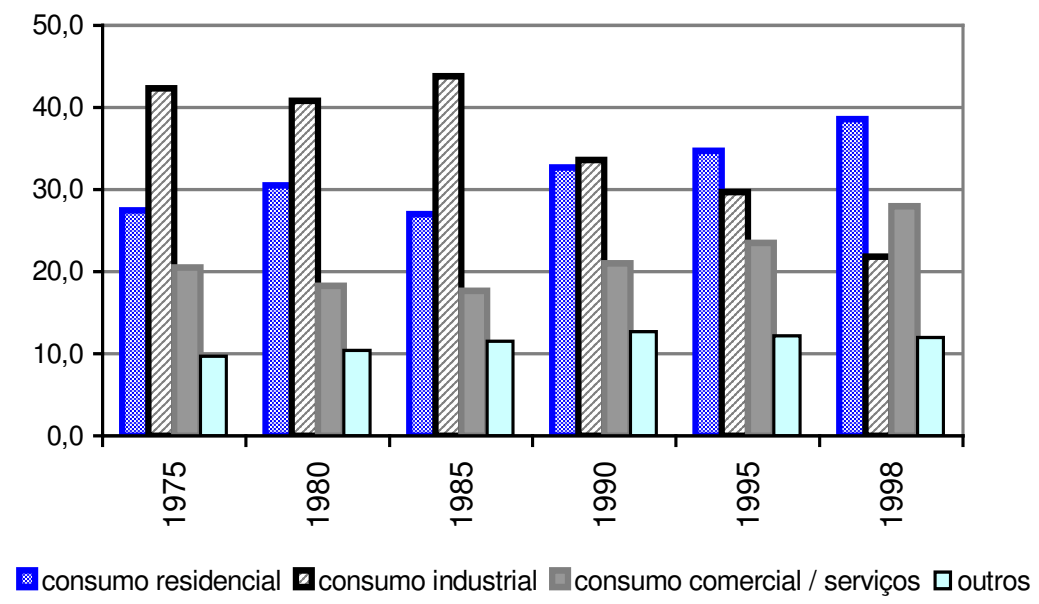

Fonte:

Dados 1975 / 1995:

Emplasa, Sumário de Dados da Grande São Paulo, 1977 / 91.

Dado 1998:

Prefeitura do Município de São Paulo, Prodam, 2000.

Quanto a evolução no consumo, os bairros ao redor do centro histórico aparecem com o maior índice de consumo de energia, utilizando mais que o dobro do segundo maior consumidor representado pela zona norte e centro histórico ${ }^{43}$.

${ }^{43}$ Considerando a divisão da Eletropaulo em centro antigo (histórico): Brás, Belenzinho, Cambuci, Santa Ifigênia, Mooca, Pari, Barra Funda, Bom Retiro e Sé. Como bairros ao redor (formando o centro expandido): Lapa, Perdizes, Jardim Paulista, Vila Mariana, Moema, Itaim Bibi, Santa Cecília, Consolação, Liberdade, Aclimação, Pinheiros, Bela Vista e Vila Madalena. Como norte: Tucuruvi, Santana, Freguesia do Ó, Vila Maria, Brasilândia, Casa Verde, Vila Guilherme, Limão, Vila Nova Cachoeirinha. 
As outras regiões mantêm consumo praticamente constante ao longo desse período.

Gáfico 2.15. Evolução do consumo de energia elétrica no Município de São Paulo (Mwh)

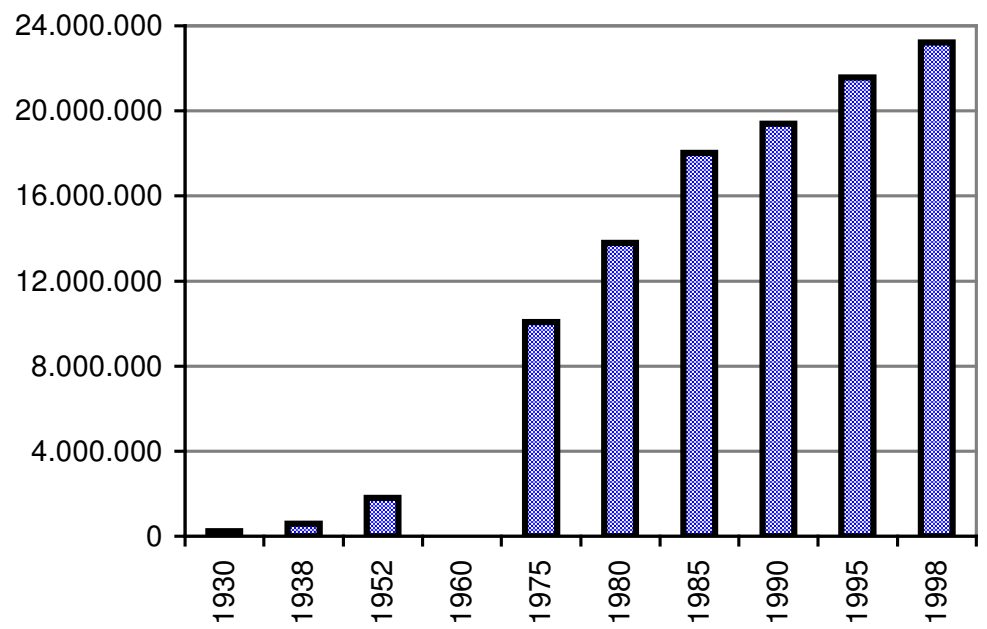

Tabela 2.11. Resumo da composição dos gráficos sobre a rede de energia elétrica ${ }^{44}$

\begin{tabular}{|c|c|}
\hline \multicolumn{2}{|c|}{ Consumo Total $\mathbf{( \text { mwh} )}$} \\
\hline $\mathbf{1 9 0 0}$ & $\mathbf{1 9 7 5}$ \\
1.000 & 10.061 .701 \\
\hline $\mathbf{1 9 1 0}$ & $\mathbf{1 9 8 0}$ \\
28.800 & 13.797 .035 \\
\hline $\mathbf{1 9 2 0}$ & $\mathbf{1 9 8 5}$ \\
76.800 & 18.021 .034 \\
\hline $\mathbf{1 9 3 0}$ & $\mathbf{1 9 9 0}$ \\
216.000 & 19.393 .853 \\
\hline $\mathbf{1 9 3 8}$ & $\mathbf{1 9 9 5}$ \\
588.488 & 21.56 .7013 \\
\hline $\mathbf{1 9 5 0}$ & 1995 \\
1.805 .015 & 21.56 .7013 \\
\hline $\mathbf{1 9 6 0}$ & $\mathbf{1 9 9 8}$ \\
não localizado & 23.216 .357 \\
\hline
\end{tabular}

Fonte:

Dado 1900/1950:

Souza, História da Light, 1989.

Dados 1975 / 1995:

Emplasa, Sumário de Dados da Grande São Paulo, 1977 / 91. Dado 1998:

Prefeitura do Município de São Paulo, Prodam.

Nota:

1960 não foi localizado.

\footnotetext{
${ }^{44}$ No gráfico 2.15. os valores anteriores a 1930 foram ignorados, por serem ínfimos quando comparados ao avanço das décadas seguintes.
} 


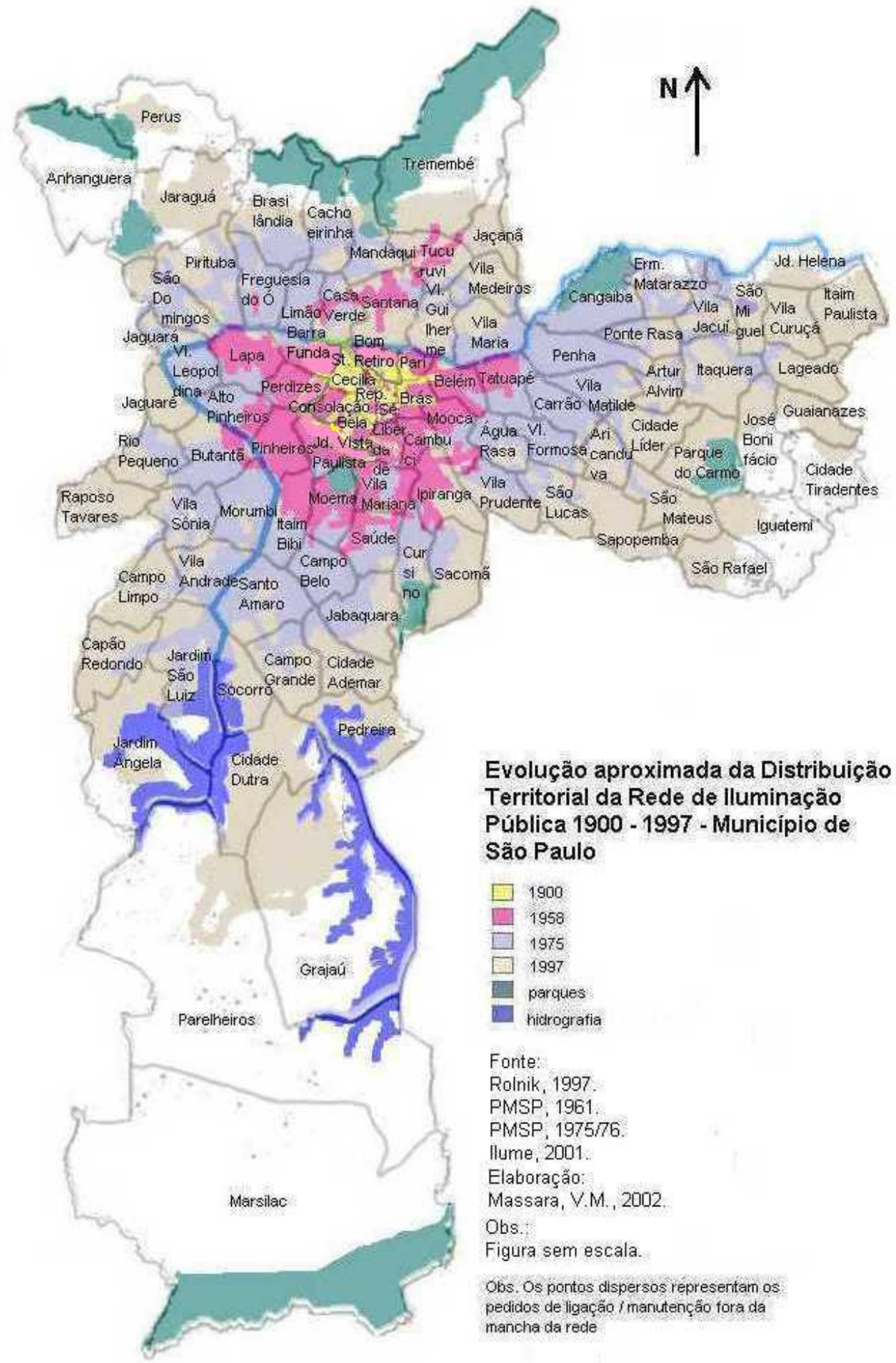

Figura 2.10. 


\subsubsection{Sistema hidráulico e complexo gerador}

$\underline{\text { Sistema hidráulico: usinas hidrelétricas, termelétricas }}{ }^{45}$

Em 1899 foi estabelecido contrato para início das atividades no Brasil da empresa The São Paulo Railway, Light and Power Company Limited.

Em 1901, o engenheiro H.L. Cooper iniciou o projeto para utilização da queda d'água localizada na Cachoeira do Inferno e criou a Usina de Parnaíba $(2000 \mathrm{Kw})$ - atual Edgard de Souza. Para transformação e distribuição da energia oriunda dessa usina, foi construída no bairro da Luz, a primeira Estação Transformadora da Cidade: Paula Souza.

Seguindo a demanda, a capacidade da usina de Parnaíba foi aumentada para 16mw em 1912; não sendo possível a criação de um reservatório para funcionamento de suas turbinas em 1906 teve início a obra em Guarapiranga.

No período de 1924, houve ampliação na capacidade da Usina Paula Souza para $10000 \mathrm{Kw}$ e, ao final de 1925, a inauguração da Usina Hidrelétrica de Rasgão, para $22 \mathrm{Mw}$. Simultaneamente foi construída a Usina de Cubatão - atual Henry Borden (1926), represando o rio Grande, criando o reservatório Rio das Pedras para alimentação dessa usina. Em 1928 foi inaugurada a Usina de Porto Goés, para 11 Mw.

Na década de 50, grande incremento foi dado a geração de energia. A Usina Hidrelétrica Henry Borden foi ampliada, foram construídas as usinas elevatórias de Pedreira, Traição e Edgard de Souza incrementando o uso do reservatório Billings (rio Pinheiros) e originando o de Pirapora (rio Tietê). O reservatório de Guarapiranga passou a ser utilizado somente para abastecimento de água. Em 1954, é inaugurada a Usina termelétrica de Piratininga.

Em 1961, a Usina de Rasgão, por problemas de infiltração foi desativada e novamente ativada em 1989, após recuperação. Caminhando pelos anos 80, percebese a preocupação com a segurança das estruturas hidráulicas para adequá-las as

\footnotetext{
${ }^{45} \mathrm{O}$ sistema elétrico é todo interligado e centralizado em grandes usinas, como por exemplo, na região Sudeste, que recebe energia gerada nas regiões sul e centro-oeste. Assim, explicar todo esse sistema é bastante complexo e não é objeto de nosso trabalho. Por isso, procuramos listar apenas as usina ligadas diretamente ao Município e que estão a cargo da EMAE.
} 
grandes vazões do Alto Tietê. Em 1999, em todas as usinas são executadas obras de melhoria.

Além das usinas mencionadas, foram construídas entre 1912/15, as chamadas "miniusinas" do Vale do Paraíba (Bocaina, Sodré e Isabel), para atender os municípios vizinhos e que atualmente estão desativadas.

A exploração do potencial hidrológico do país, induziu a criação de usinas hidrelétricas ao invés da utilização de combustíveis fósseis, como o petróleo ou o gás. Também o fator do alto investimento inicial, praticamente dispensar investimentos posteriores, ao contrário das termelétricas que necessitam de investimento constante, contribuíram para que a utilização desse tipo de usina não fosse cogitado, até há pouco, com a ameaça de crise energética.

A única experiência concretizada é a da Usina Termelétrica de Piratininga (1954); o próximo estágio é ampliação da sua capacidade e a criação da Usina termelétrica em Cubatão, evidenciando a co-geração como alternativa a escassez de energia.

Tabela 2.12. Evolução da capacidade das usinas do complexo Light - Emae em uso atualmente

\begin{tabular}{|l|l|c|c|c|}
\hline \multicolumn{1}{|c|}{ Usinas geradoras de energia } & Tipo & Inauguração & Capac. Inicial & Capac. Atual \\
\hline Rasgão & hidrelétrica & 1925 & $22 \mathrm{Mw}$ & $22 \mathrm{Mw}$ \\
Porto Goés & hidrelétrica & 1928 & $11 \mathrm{Mw}$ & $11 \mathrm{Mw}$ \\
Cubatão (Henry Borden) & hidrelétrica & 1926 & $28 \mathrm{Mw}$ & $889 \mathrm{Mw}$ \\
Piratininga & termelétrica & 1954 & $472 \mathrm{Mw}$ & $472 \mathrm{Mw}$ \\
\hline
\end{tabular}

Fonte:

Dados de inauguração:

Souza, História da Light, 1989.

Dados atuais:

Emae, Sistema Hidráulico / Complexo gerador, 2001.

$\underline{\text { Complexo gerador: usinas elevatórias, barragens e reservatórios }}$

Completando o sistema de geração de energia, foram construídas barragens e reservatórios, com a função principal de controlar os fluxos que chegavam aos reservatórios:

- 1900/01: Edgard de Souza; 
- 1906/09: Guarapiranga;

- 1926: Rio das Pedras (para ajudar na alimentação da Usina Henry Borden);

- 1926/37: Rio Grande;

- 1928: Da Cascata (desativada);

- 1929: Guarapiranga (atualmente utilizada para o abastecimento de água);

- 1936: Billings - das Pedras;

- 1937: Billings: para fins múltiplos como geração de energia, saneamento e controle de cheias, seccionado em 1981 formando dois compartimentos: o de Pedreira e o do Rio Grande

- 1954/56: Pedreira (desativada);

- Barragem do Retiro

- 1956: Pirapora: colaborando na alimentação da Usina Henry Borden e atualmente para controle das cheias do Tietê.

Figura 2.11. Esquema genérico do sistema hidráulico da EMAE ao redor do Município de São Paulo ${ }^{46}$

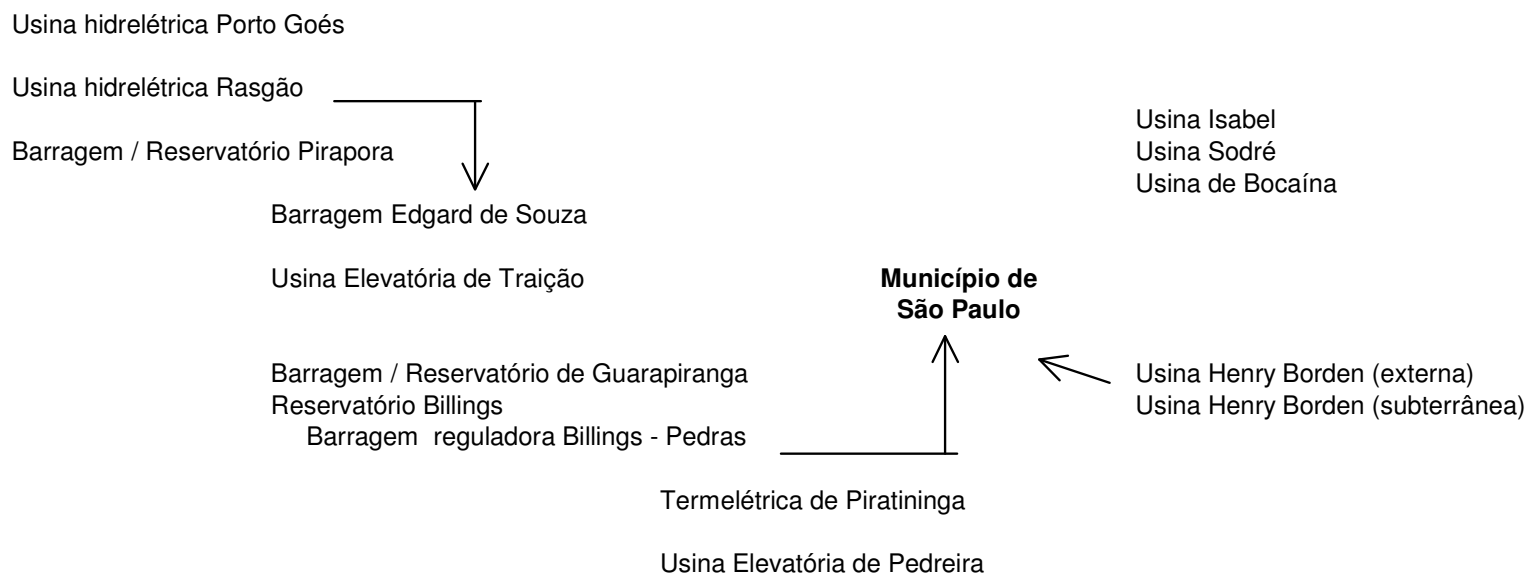

Fonte: Elaboração a partir de dados da EMAE, 2001.

${ }^{46}$ A usina Edgard de Souza foi desativada em 1984 e sua unidade transferida para a Usina elevatória de Pedreira. As usinas Isabel, Sodré e Bocaína, estão desativadas. 


\subsubsection{Estações transformadoras de distribuição de energia ${ }^{47}$}

A energia gerada pelas usinas é transportada por cabos de alta tensão e chegando na cidade é convertida em baixa tensão e distribuída para os distritos. Para tal, são utilizadas estações transformadoras, retificadoras, de transição e banco de capacitores. Atualmente, devido a alta densidade de carga concentrada no centro expandido, aliada a impossibilidade de construção de novas estações por falta de terrenos de grande porte nessa região há uma tendência de encarecimento do serviço nessa área e surge como um dos principais aspectos negativos para o adensamento do centro da cidade.

Período 1900/1950

- 1901: Paula Souza; 1908: Lapa e Mooca; 1911: Ipiranga; 1913: Augusta e Santo Amaro; 1914: Belenzinho; 1916: Cambuci e Saúde; 1925: Vila Mariana; 1927: Pirituba; 1929: Pinheiros e Riachuelo; 1940: Baquirivu ( São Miguel Paulista); 1942: Penha;

\section{Período 1950/1980}

- Cidade Universitária; Comandante Taylor; Planalto Paulista; Berrini; Jabaquara; Monumento; São João Clímaco; Alto da Boa Vista; Água Branca; Alexandre de Gusmão; Americanópolis; Anastácio; Anhembi; Planalto Paulista; Brás; Buenos Aires; Butantã; Canindé; Capela; Casa Verde; Centro; Continental; Gomes Cardim; Guarapiranga; Hipódromo; Ibirapuera; Itaim; Jaguaré; Jardim da Glória; Lapa; Leopoldina; Limão; Monte Santo; Morumbi; Oratório; Parque São Domingos; São Mateus; Sumaré; Tomas Edison, Tucuruvi; Vila Ema; Vila Guilherme; Vila Medeiros, Vila Talarico, Vila Prudente, Vila Almeida, Padre Adelino (junção Guarulhos), Guarulhos (junção Guarulhos).

\footnotetext{
${ }^{47}$ Em contato com a Coordenação de entendimento com as concessionárias e entidades de direito público e privado da Eletropaulo fomos informados que dados recentes sobre capacidade das estações e novas instalações são considerados estratégicos impossibilitando sua divulgação.

Em 2001, tivemos notícia que existe um mapa na biblioteca da Eletropaulo intitulado: Sistema Energético de São Paulo 1993-1995 que possui a localização das estações, em novo contato com a concessionária não encontramos esse esquema.
} 


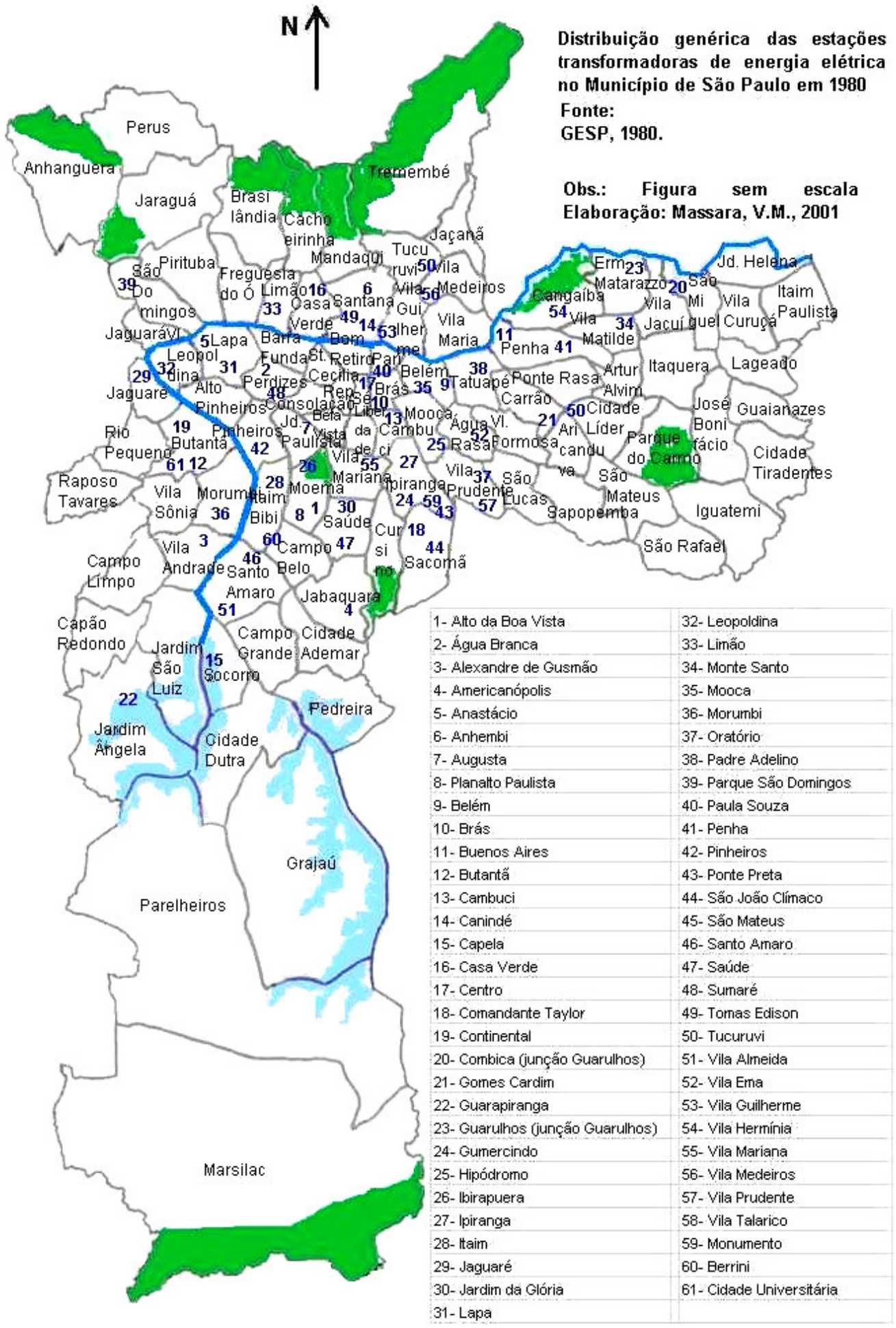

Figura 2.12. 


\subsection{Telecomunicações}

\subsubsection{Telefonia}

\subsubsection{Concessão dos serviços}

Supõe-se que a primeira estação telefônica no Estado de São Paulo foi instalada em 1883 na Cidade de Santos. No ano seguinte são postos em funcionamento os primeiros telefones na cidade de São Paulo: 22 assinantes.

Dez anos depois, o Padre Landell de Moura realiza com êxito, também em São Paulo, "as primeiras transmissões de sinais telegráficos e da voz humana em telefonia sem fio do mundo.” (MUSEU DO TELEFONE, 1977, s.p.).

No final do século XIX é fundada a Companhia Rêde Telephonica Bragantina - CRTB , formando o "Império Bragantino" que perdurou até 1916.

Segundo LEÃO, havia grande deficiência no serviço: dificuldade em completar ligações, interrupção das ligações completadas, somada a excessiva tarifa cobrada pela empresa - que tinha como obrigação imposta por lei, prestar contas a Prefeitura das alterações pretendidas: "A Telefônica vem se esquivando ao cumprimento da mais explícita das suas obrigações, a saber: - submeter suas tarifas à aprovação da Prefeitura” (LEÃO, 1941, p. 12).

Nos anos 20, surgem os telefones "semi-públicos”, localizados em padarias, farmácias, etc.. Em 1928 é inaugurada a primeira central telefônica automática em São Paulo, no centro - desativada em 1997. Nas décadas de 30 e 40, ocorre a criação e incremento do serviço de ligações com "pagamento prévio", enquanto a deficiência no serviço para linhas particulares aumentava: o desenvolvimento da cidade não foi acompanhado pela ampliação do sistema telefônico.(LEÃO, 1941, p.133)

A década de 50 é marcada pela ativação da central automática da Vila Mariana, seguida por outras nos anos seguintes e pelos avanços tecnológicos no campo da "discagem a distância".

Em 1972, é colocado em funcionamento o primeiro telefone público; ênfase em projetos-piloto para otimizar ligações interurbanas. Em 1982, é ativado na favela de Vila Prudente, o primeiro "orelhão comunitário", possibilitando o recebimento de chamadas.

Em síntese a cronologia da concessão do serviço de telefonia no Município é descrita a seguir: 
1896: a Companhia Rêde Telephonica Bragantina - CRTB

data não localizada: Companhia Telefônica Bragantina - CTB

1912: grande parte das ações é vendida à inglesa Telephone Developement Company originando a Brasilian Traction, Light and Power Company data não localizada (década de 20): Companhia Telefônica Brasileira

1965: Empresa Brasileira de Telecomunicações - Embratel

1973: Telecomunicações de São Paulo S.A. - Telesp

1972: Telecomunicações Brasileiras S.A. - Telebrás

1992: serviços de "vídeo conferência" pela Telesp

1998: Telesp Participações tem como lider no consórcio a Telefonica ( grupo espanhol) e a Telesp Celular ( concessão portuguesa)

1998: sistema banda B de celulares pela empresa BCP

2000: Introdução de novas empresas para distribuição de linhas em São Paulo: Vésper e Intelig.

Após a privatização de 1998, com a grande expansão da instalação de terminais telefônicos na cidade de São Paulo, a divisão técnica foi reformulada, considerando que houvesse equilíbrio entre os dois setores.

Desta forma a antiga divisão oeste: Vila Mariana, Santo Amaro e Lapa, deu origem a sete diferentes setores:

- Vila Mariana (antiga DOW1) : região abrangida pelos setores EW1 e EW3;

- Santo Amaro (antiga DOW2): região abrangida pelos setores EW2 e EW7;

- Lapa (antiga DOW3): região abrangida pelos setores EW4 e EW5.

O mesmo ocorreu com a antiga divisão leste: Consolação, Ipiranga e Penha, originando quatro setores:

- Consolação (antiga DOL1) : região abrangida pelos setores EL1 e EL3;

- Ipiranga (antiga DOL2): região abrangida pelos setores EL2 e EL4;

- Penha (antiga DOL3): região abrangida pelos setores EL5 e EL6 ${ }^{48}$. 


\subsubsection{Distribuição territorial: telefones particulares e públicos}

A expansão dessa rede foi bastante morosa. Até a primeira metade do século $\mathrm{XX}$, ficou estagnada no centro histórico e pequena região ao redor. No final dos anos 60 se concentrava na região central, oeste e pequena parte da leste, com poucas ramificações nas outras direções, sendo muito comum o uso introduzido na década de 20 de telefones em locais comerciais.

Dados de 1991, mostram que o maior índice de atendimento está em áreas residências de alto e médio padrão, concentradas no Campo Belo, Ibirapuera e Vila Mariana e em áreas já consolidadas como Ipiranga e Santana.

Na metade da década de 90, o número de terminais telefônicos cresceu vertiginosamente e em 1997, ocorreu a expansão definitiva dos orelhões que recebem chamada.

Gráfico 2.16. Evolução do número de telefones em serviço na década de 90.

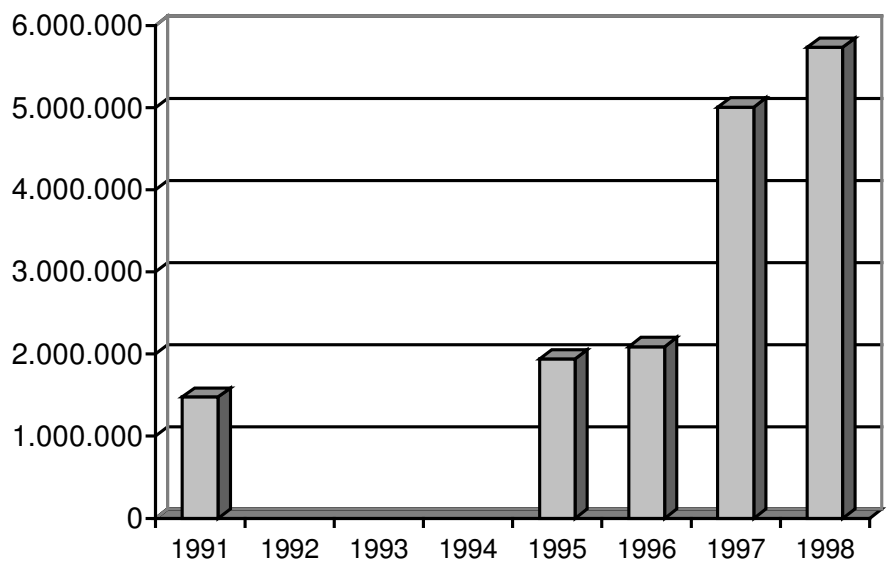

Tabela 2.13. Evolução do número de telefones em serviço na década de 90.

\begin{tabular}{|c|c|c|c|c|c|}
\hline Ano & Uso residencial & Uso não residencial & Uso público & Troncos & Total \\
\hline 1991 & 981.397 & 350.307 & 23.512 & 120.202 & 1.475 .418 \\
1995 & 1.152 .539 & 489.491 & 37.502 & 258.362 & 1.937 .894 \\
1996 & 1.246 .506 & 514.228 & 44.324 & 283.180 & 2.088 .238 \\
1997 & 3.384 .126 & 999.322 & 137.288 & 486.613 & 5.007 .349 \\
1998 & 3.936 .235 & 1.056 .270 & 144.543 & 598.299 & 5.735 .347 \\
\hline
\end{tabular}

Fonte: Companhia energética de São Paulo, 1995; Prefeitura do Município de São Paulo, Prodam, 2001.

Nota: Dados de 1992 / 1994 não foram localizados.

${ }^{48}$ As siglas e descrição dos setores está representada nas figuras 2.13 e 2.14 , quando relacionamos os setores administrativos às centrais telefônicas e a sua área de influência. 
No período 1998/99 ocorreu a expansão da rede particular, pela privatização e criação de outras empresas que dinamizaram o avanço, embora a densidade de aparelhos em distritos periféricos ainda seja pequena.

Gráfico 2.17. Evolução do número de telefones por 1000 habitantes no Município de São Paulo

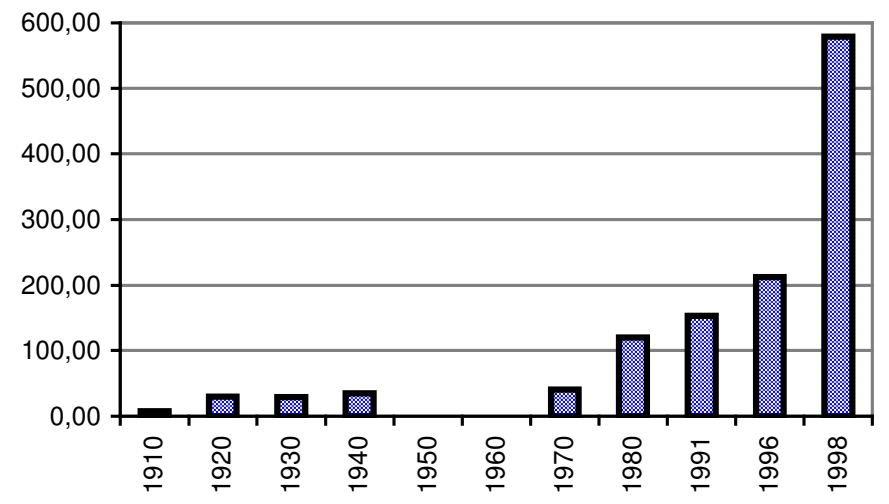

Tabela 2.14. Evolução do número de telefones por 1000 habitantes no Município de São Paulo

\begin{tabular}{|r|r|r|r|}
\hline Ano & População & $\begin{array}{l}\text { Terminais } \\
\text { instalados }\end{array}$ & Densidade \\
\hline 1910 & 315.000 & 2.520 & 8,0 \\
\hline 1920 & 579.086 & 17.372 & 30,0 \\
\hline 1930 & 887.810 & 27.744 & 32,0 \\
\hline 1940 & 1.378 .539 & 48.248 & 35,0 \\
\hline 1950 & 2.278 .000 & não localizado \\
\hline 1960 & 3.709 .274 & não localizado \\
\hline 1970 & 5.978 .977 & 243.000 & 40,6 \\
\hline 1980 & 8.493 .226 & 1.025 .510 & 120,7 \\
\hline 1991 & 9.646 .185 & 1.475 .418 & 153,0 \\
\hline 1996 & 9.839 .436 & 2.088 .238 & 212,2 \\
\hline 1998 & 9.917 .817 & 5.735 .347 & 578,3 \\
\hline
\end{tabular}

Fonte:

Dados 1910/1940:

Leão, M.L.. Revisão das Tarifas do serviço telefônico da cidade de São Paulo, 1941.

Dados 1970:

Emplasa, Sumário de Dados da Grande São Paulo, 1977.

Dado 1980/1996:

Emplasa, 1997.

Dado de 1998:

Prefeitura do Município de São Paulo, Prodam, 2001.

\subsubsection{Centrais telefônicas}


Da central partem as linhas dos assinantes, de forma que sua ótima localização corresponde a menor distância possível entre ambas. Em 1940, a cidade contava com 6 estações centrais (1 manual; 5 automáticas) e mais 4 estações periféricas: Lapa, Tatuapé, Santana e Ipiranga (automáticas).

Informações obtidas com a Telefonica ${ }^{49}$ após a privatização, mostram uma redivisão dos setores, visando a separação por áreas de atendimento, levando em conta o número de aparelhos já em serviço, de modo a deixar cada setor com número equilibrado de terminais, considerando expansão futura. A concentração de terminais comerciais está localizada no setor EW2 e em menor escala, nos outros setores. Está divisão (ew2) também reúne o uso residencial de médio e alto padrão.

Figura 2.13. Unidades de Controle, centrais telefônicas e área de influência - divisão oeste

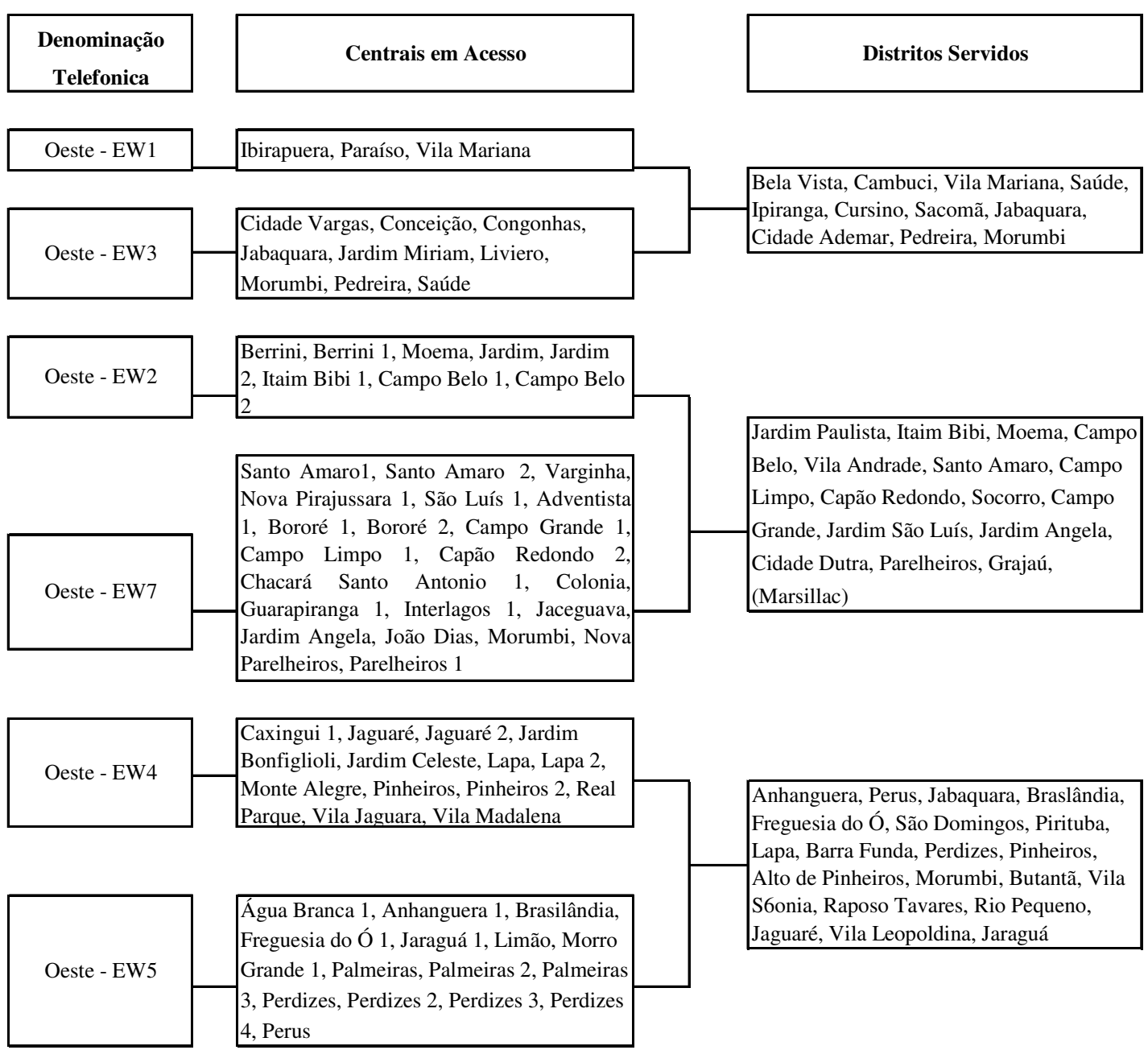

Fonte: Elaboração do esquema a partir de dados da Telefônica, 2000.

${ }^{49}$ Informações obtidas através de contato com a Superintendência Técnica da Telefonica, 2000. 
A divisão Leste concentra todos os bairros em expansão e mais a rede antiga na região do centro histórico, representada pelos setores EL1e EL4, de forte característica comercial. Já os setores EL2 e EL7, representam a expansão nos distritos periféricos de uso basicamente residencial.

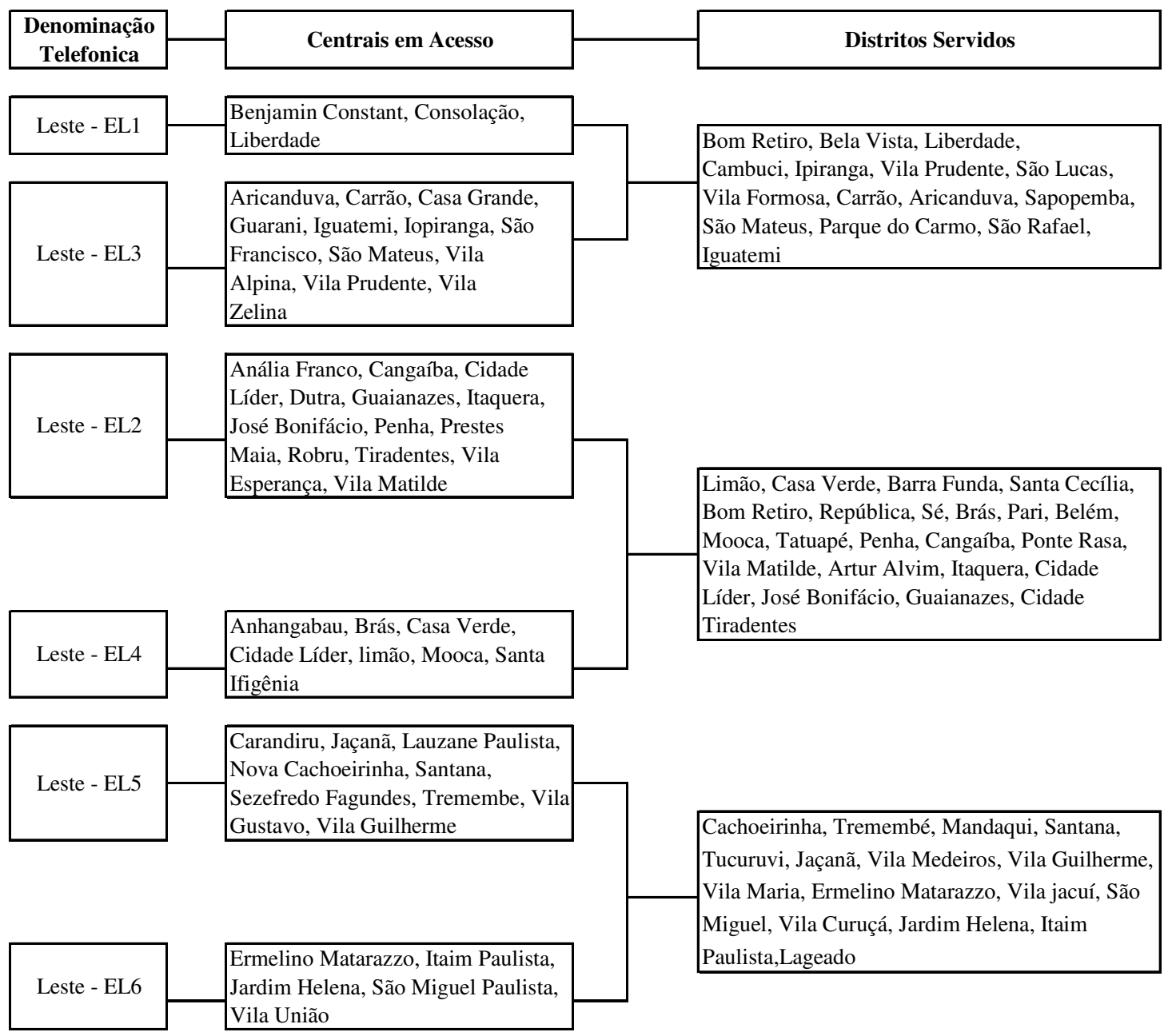

Figura 2.14. Unidades de controle, centrais telefônicas e área de influência - divisão leste Fonte: Elaboração do esquema a partir de dados da Telefônica, 2000.

\subsubsection{Telefonia celular}

Em 1993, foi inaugurada a telefonia móvel analógica em São Paulo (lembrando que no Japão já era utilizada desde 1978; e no Brasil, no Rio de Janeiro, a primeira experiência data de 1990). Em 1998 teve início o funcionamento dos celulares digitais em banda B (pela BCP), na região metropolitana de São Paulo. Em 2000/01, aparelhos celulares possibilitam ligação com correio eletrônico; lançamento dos "pré-pagos", diminuindo os custos de aquisição e manutenção e conseqüentemente expandindo o uso dos telefones móveis. 


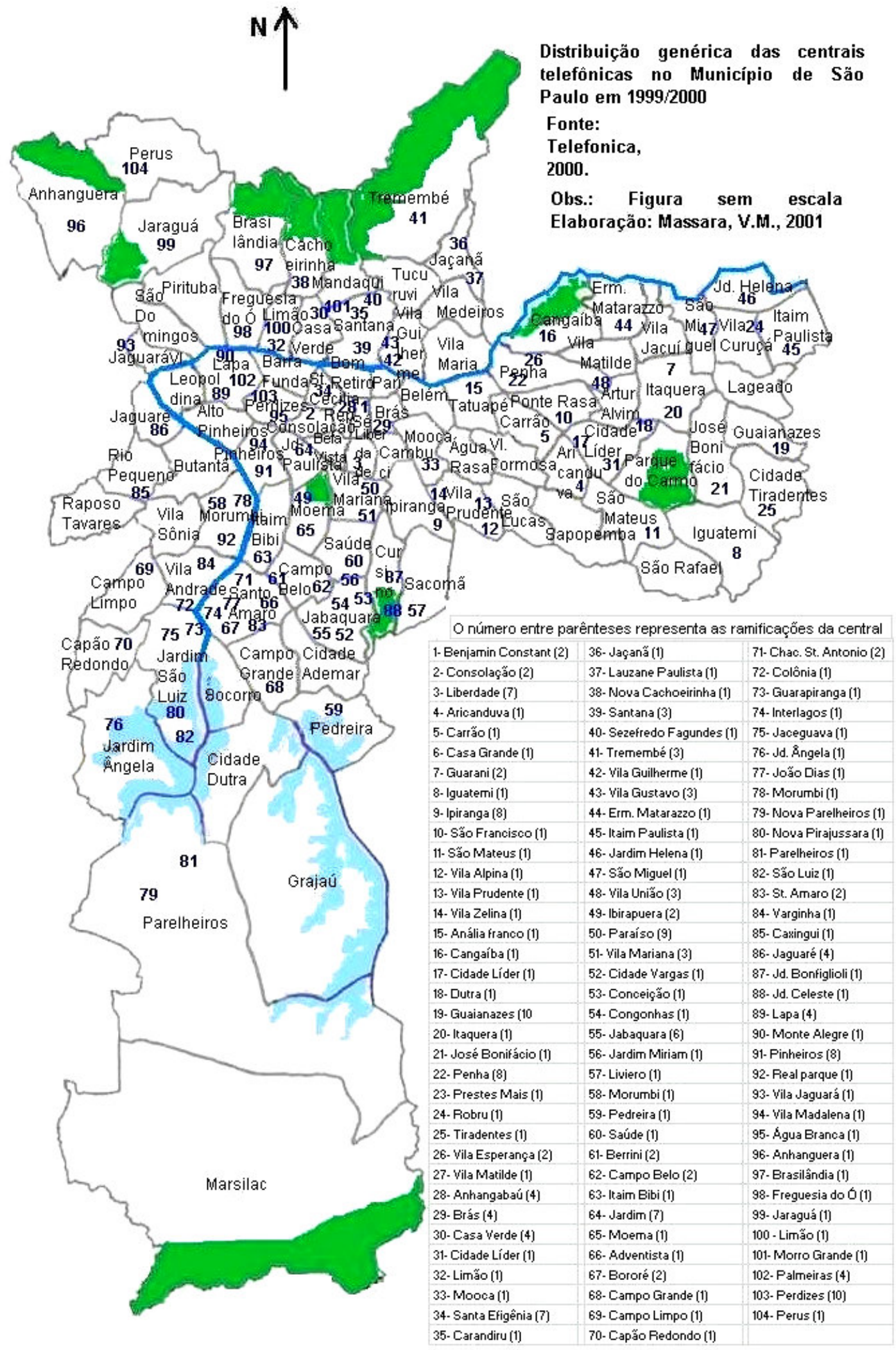

Figura 2.15. 


\subsubsection{A rede de cabo óptico}

\subsubsection{Concessão do serviço}

Com a implantação da rede em 1985, a Embratel iniciou o controle da distribuição dos serviços, em geral, terceirizando a execução da implantação com empresas ligadas a área de Telecomunicações.

Na metade da década de 80 , tem início a implantação da rede de cabos ópticos no Município de São Paulo, através das Estações Basílio da Gama e Santa Efigênia, primeiro com a intenção de diminuir o diâmetro dos cabos telefônicos (atualmente também visando diminuição do diâmetro de cabos de energia elétrica).

As peculiaridades dos cabos ópticos, conseguem eliminar por completo a possibilidade de interferências, além de reduzir os custos e multiplicar a capacidade de transmissão das informações.

Atualmente, a existência dessa rede em novos centros comerciais, funciona como uma vantagem competitiva, além de determinar mudanças nos projetos de escritórios - cada vez menores - em contraposição aos antigos localizados no centro histórico (NOBRE, 2000).

No caso das empresas de tv a cabo, existe três divisões de controle:

- a programadora que tem como única incumbência formatar os canais e sua programação;

- a distribuidora que tem como função comercializar a produção da programadora;

- a operadora, que planeja, constrói e instala a rede de cabos até os edifícios e residências.

A operadora em geral, faz a instalação dos cabos por via aérea, utilizando-se dos postes de energia elétrica, assim como a rede de telefonia. O preço de aluguel dos postes funciona segundo regulamento entre a Aneel e Anatel ${ }^{50}$ (no caso dos telefones); já no caso do uso para cabos ópticos, ainda está em elaboração o regulamento que deve determinar os valores cobrados pelo compartilhamento da infra-estrutura.

\footnotetext{
50 Aneel: Agência Nacional de Energia Elétrica; Anatel: Agência Nacional de Telecomunicações; ambas com a função de gerenciar a qualidade dos serviços e o valor da tarifa cobrado pelas concessionárias.
} 
Para o sistema de otimização de dados computacionais (internet), também existe uma combinação entre a rede de telefonia e a instalação dos cabos; programas como o "Speedy", estão apoiados na existência dos cabos e podem utilizar a rede já instalada para o uso de canais a pagamento.

Figura 2.16. Esquema de utilização simultânea dos postes para as redes de energia elétrica, telefonia e cabo óptico ${ }^{51}$. Elaboração: Massara, V.M.,2001.

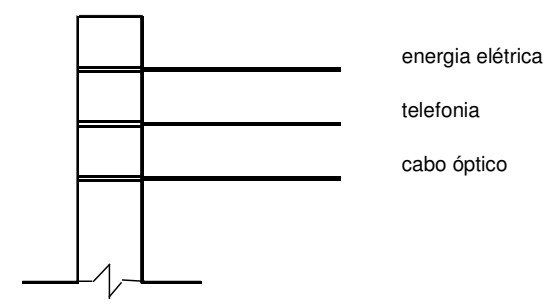

\subsubsection{Distribuição territorial da rede: diminuição do diâmetro de cabos de telefonia e energia, otimização de dados computacionais e tv a cabo}

A expansão, concentrada no final da década de 80 e início dos anos 90, começou na região do centro histórico, dirigindo-se então para bairros de razoável poder aquisitivo. A rede de cabos para tv por assinatura, é inexistente em distritos periféricos da zona leste: Vila Curuçá, Jardim Helena, Itaim Paulista, Guaianazes, Artur Alvim, Cidade Líder e Cidade Tiradentes; da zona sul: Jardim Ângela, Parelheiros, Marsillac, na zona noroeste: Anhanguera, Perus; Raposo Tavares e na zona norte: Brasilândia. A existência da rede parece não estar totalmente vinculada ao poder aquisitivo dos habitantes da área servida; considerando que ruas de bairros como Grajaú, Jardim São Luiz, Vila Jacuí e Cidade Adhemar já dispõe dessa infraestrutura. Desta forma, a evolução desse serviço parece progredir rapidamente, dependendo da possibilidade oferecida pela renda da população de possuir uma linha telefônica, um equipamento de computador e pagar as mensalidades da tv a cabo, mas também ao número de pedidos de assinatura por distrito versus custo e facilidades técnicas para esticar a rede a pontos mais longínquos.

\footnotetext{
51 Aqui vale lembrar, que a Prefeitura do Município de São Paulo, em dezembro de 2001, iniciou projeto através do seminário: "Uso do subsolo e espaço aéreo urbano", visando interferir na poluição visual causada pelo número de fios instalados nos postes, com a pretensão de a médio/longo prazo, tornar todas as redes subterrâneas. Embora não seja objeto deste estudo, consideramos pertinente comentar a relação entre o custo de implantação e manutenção das redes aéreas e subterrâneas bem como a necessidade de mapeamento digitalizado das redes existentes no sub-solo (atualmente só encontrado em pequenas áreas), para a sua perfeita localização.
} 


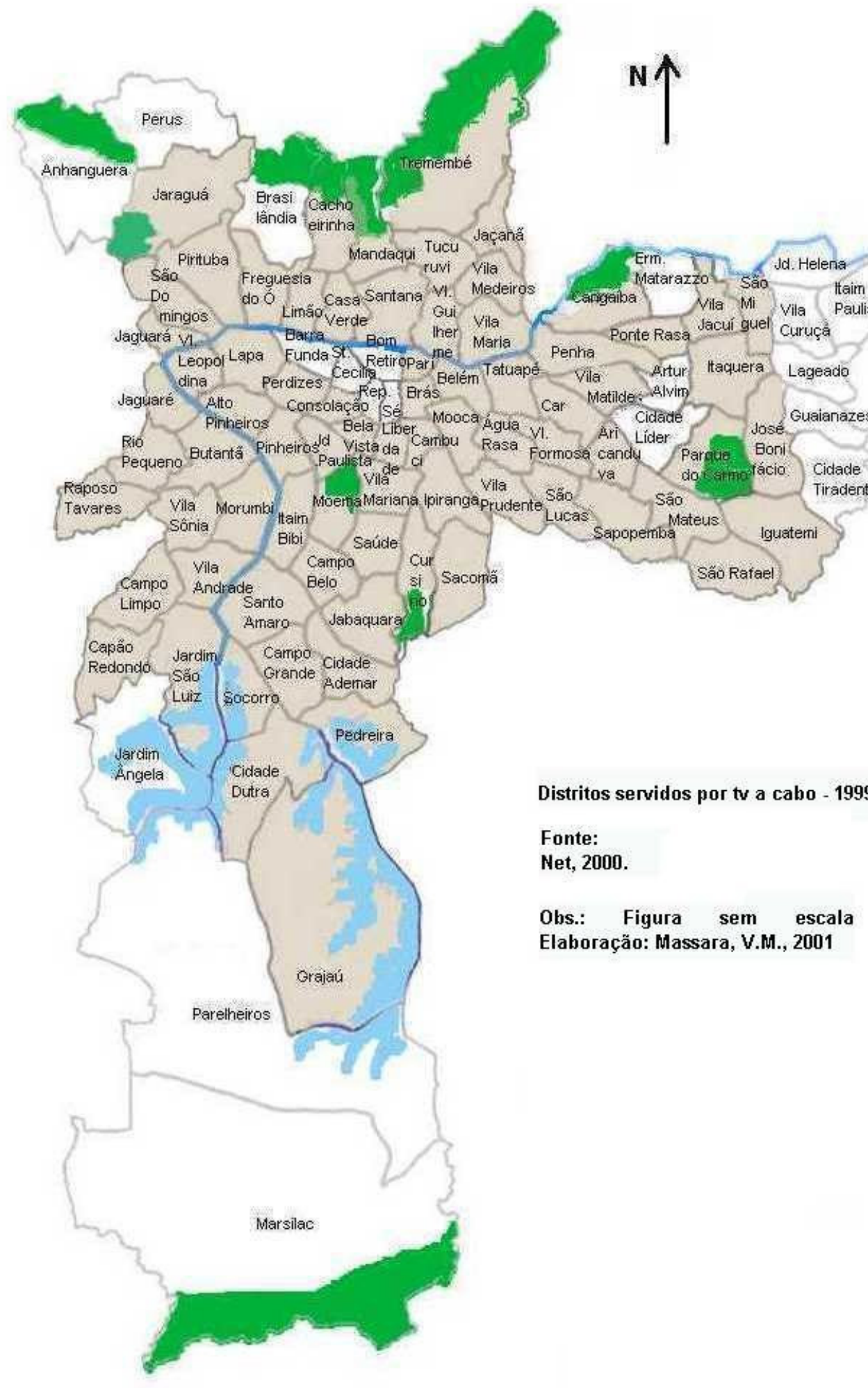

Figura 2.17. 


\section{Capítulo 3. A implantação de infra-estrutura e as transformações no uso do solo: o centro expandido no período 1890-1999}

\subsection{A escolha do centro expandido}

A combinação de dois fatores resultou na seleção dessa área como objeto de detalhamento das redes. O primeiro deles, está baseado na característica da região de concentrar todos os serviços: "os grandes entroncamentos de transporte de massa e os principais nós das redes de água, esgoto, energia elétrica, telefonia e gás encanado ou estão diretamente localizados na zona central ou estão à ela vinculados de forma praticamente irreversível” (TOLEDO SILVA, 1995, p.19), fornecendo condição ideal para expansão de usos e conseqüente desenvolvimento econômico.

O segundo, se refere a inter-relacionar este trabalho com outros estudos, visando a elaboração de um perfil da evolução do Município através da distribuição territorial das infra-estruturas e das transformações nos usos do solo, envolvendo fatores como valorização imobiliária, distribuição de renda e de população versus o desenvolvimento econômico e social de áreas centrais e periféricas.

Dando sequência a trabalhos iniciados por BARBOSA (2001), que faz um estudo detalhado sobre legislação e a dinâmica da evolução no uso do solo para o centro expandido no período de 1860 a 1999, montamos mapas específicos para essa região, com o avanço das redes de abastecimento de água, coleta de esgotos, gás canalizado, iluminação pública, cabo óptico e telefonia usando como referência seus mapas sobre as principais transformações ocorridas em 4 períodos ${ }^{52}$ :

- Primeiro Período: 1890-1922;

- Segundo Período: 1922-1952;

- Terceiro Período: 1952-1972;

- Quarto Período: 1972-1999.

Introduzindo informações sobre as redes para cada período de transformação no uso do solo, verificamos a relação entre a implantação dos serviços e o tipo de ocupação em função do histórico de expansão dos bairros e de sua localização. ${ }^{52}$ O primeiro período (1860-1890) estudado por BARBOSA (2001) foi desconsiderado por não
apresentar avanços nas redes de infra-estrutura. 
Como centro expandido foi considerado o perímetro determinado pela Empresa Metropolitana de Planejamento - EMPLASA (1993), que tem como limites os rios Tietê e Pinheiros e importantes avenidas como mostra a figura 3.1.

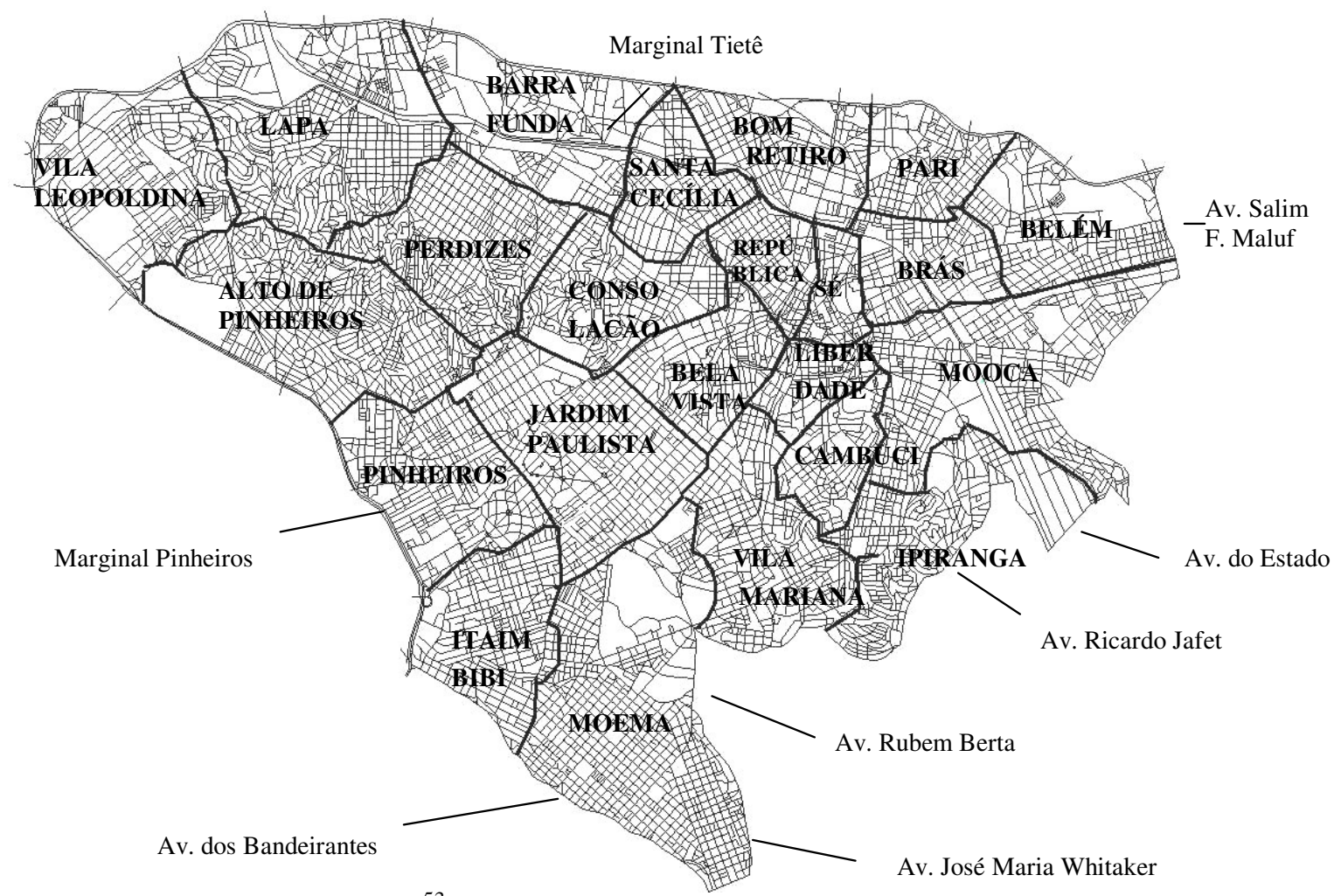

Figura 3.1. Centro expandido ${ }^{53}$ segundo Emplasa, 1993.

Nota: figura sem escala

Fonte: Malha viária: Barbosa, 2001; Distritos: Sempla, 2000.

\footnotetext{
${ }^{53}$ Com o objetivo de associar o histórico dos bairros a dados do IBGE e das concessionárias, usamos um perímetro aproximado que permita relacionar todas as denominações a divisão em distritos da Prefeitura (1991): -Distrito Moema: Moema, Indianópolis, Planalto Paulista -Distritos Vila Leopoldina e Lapa: Vilas Leopoldina, Hamburguesa e Anastácio, Alto da Lapa, Lapa de Baixo, Vila Romana

-Distrito Pinheiros: Pinheiros, Alto de Pinheiros, Vila Madalena, Boaçava

-Distrito Itaim Bibi: Itaim Bibi, Vila Olímpia, Vila Funchal;

-Distrito Vila Mariana: Vila Mariana, Ibirapuera

-Distrito Jardim Paulista e Consolação: Cerqueira César, Paraíso, Jardim Paulista, Jardim América, Jardim Europa, Jardim Paulistano, Consolação

-Distrito Sé: Sé, Santa Ifigênia e Luz

-Distrito Santa Cecília: Campos Elíseos, Santa Cecília, Higienópolis, Vila Buarque

-Distrito Barra Funda: Água Branca, Barra Funda

-Distritos Liberdade e Cambuci: Liberdade, Aclimação, Cambuci

- Distrito Perdizes: Pompéia, Perdizes, Sumaré, Pacaembu.
} 


\subsection{Características históricas}

"sendo as áreas centrais as que possuem melhor infraestrutura no município, pode-se concluir que a pressão exercida em seu nome, por investimentos públicos e privados, tende a criar um círculo vicioso de concentração de renda e riqueza no território urbano."

(SEMPLA, 2000, vol.3 p.42)

A história da formação do "centro" se confunde em parte com a história do desenvolvimento de São Paulo.

A escolha do local para fixação do colégio indigenista - o promontório, na proximidade da ligação entre os rios Anhangabaú e Tamanduateí - definiu o marco de expansão urbana da cidade.

Até o século XVIII, houve pouco desenvolvimento, alguns bairros se formaram ao redor das igrejas ${ }^{54}$ e dos Caminhos das Tropas ${ }^{55}$. No século seguinte, a ocupação foi intensificada ao redor dos chafarizes públicos para abastecimento de água e a partir de 1867 , ao longo do traçado das ferrovias ${ }^{56}$. Já no final deste período, diversos fatores contribuíram para a expansão da cidade: a abolição da escravatura, a chegada dos imigrantes e a proclamação da República, a quebra do Banco Mauá desencadeando um processo de loteamento das chácaras, transformando o investimento em terras em um mercado lucrativo e considerado como o único realmente seguro. : "quase todos os proprietários de antigas chácaras, que então existiam nos bairros de Santa Efigênia, Bom Retiro, Brás, Consolação, Liberdade e Cambuci, mandaram abrir diversas ruas, avenidas, alamedas e largos” (MARTINS, s.d. p.163-164).

Com esta nova visão, os limites precisos do terreno passam a ser importantes, bem como a preocupação sobre o alinhamento e demarcação da servidão pública.Tem início a formação de bairros sob a divisão da cidade em classes sociais.

\footnotetext{
${ }^{54}$ Como no caso do Brás, tendo o núcleo inicial ao redor da igreja de Bom Jesus dos Matosinhos.

55 Esses caminhos funcionavam como ligação entre as "freguesias" e também na ligação da província com outros estados. Como exemplos, podemos citar o bairro da Luz, ligação para Santana, Sul de Minas, São João de Atibaia, Nazaré, Juqueri e Conceição dos Guarulhos (Caminho do Guaré); o bairro da Lapa, pela Ponte do Anastácio, na ligação com a Vila de Itu. E os Caminhos do Mar, para Santo Amaro (caminho do Carro), para Penha de França e Água Branca; Rua da Consolação, caminho para Sorocaba; entre outros.

${ }^{56}$ Como os bairros do Ipiranga, Mooca, Cambuci, Brás, Pari, Barra Funda, Água Branca e Lapa.
} 
As tradicionais famílias paulistanas e os bem-sucedidos comerciantes europeus ocupam primeiro os Campos Elíseos e a seguir Higienópolis e a Avenida Paulista e os Jardins 57 e mais tarde se expandem para a zona oeste; o chamado "Triângulo" formado pelas Ruas Direita, XV de Novembro e São Bento ganha importância como espaço elegante de comércio e lazer. A construção do Viaduto do Chá, expande os limites para a Praça da República e consolida o "centro novo".

Operários nacionais e vindos de outros países, principalmente da Itália se espalham pelos bairros populares de características industriais: Bom Retiro, Barra Funda, Brás, Cambuci, entre outros. Ex-escravos e imigrantes ocupam bairros como Santa Efigênia e Bela Vista, sob a forma de cortiços tidos como "ninhos de tuberculose" e que deveriam ser retirados das áreas centrais.

Havia então, dois grandes ramos no negócio imobiliário: os bairros residenciais, bem servidos de infra-estrutura e o subúrbio, um espaço ainda não regulado pela legislação. A expansão da cidade a partir de 1920, tendo como base as facilidades oriundas da introdução do automóvel e ônibus como meios de transporte e dos projetos viários - como a implantação de alguns projetos de Planos de Avenidas $^{58}$ - dá novo impulso a cidade.

O processo de "verticalização" iniciado entre os anos 40 e 50 e enfatizado na década de 70, traz diversos estilos arquitetônicos, mudanças de gabarito na determinação de altura e de coeficientes de aproveitamento pelas determinações das leis de zoneamento,e vai se tornando um importante mecanismo da indústria imobiliária. Os bairros a sudoeste da cidade: Pinheiros, Itaim Bibi, Moema e Ibirapuera, adquirem o aspecto de região para a classe média e alta.

Outros centros são criados. O centro antigo, saturado e congestionado, se expande nos anos 60, para a Avenida Paulista. Embora outros núcleos de prestação de serviços tenham sido formados nos últimos decênios, como os das Avenidas Brigadeiro Faria Lima e Luis Carlos Berrini ${ }^{59}$, a importância da Avenida inaugurada há mais de um século ainda é preponderante.

\footnotetext{
57 Correspondendo ao conjunto formado pelo Jardim Paulista, Jardim Paulistano, Jardim Europa e Jardim América.

${ }_{58}$ Quando mencionamos "Planos de Avenidas", nos referimos a todos os projetos para o sistema viário como os de Prestes Maia e outros anteriores.
} 


\subsection{Características gerais da população e ocupação}

\subsubsection{População}

Gráfico 3.1. Evolução da população na região do centro expandido ${ }^{60}$ (mil hab)

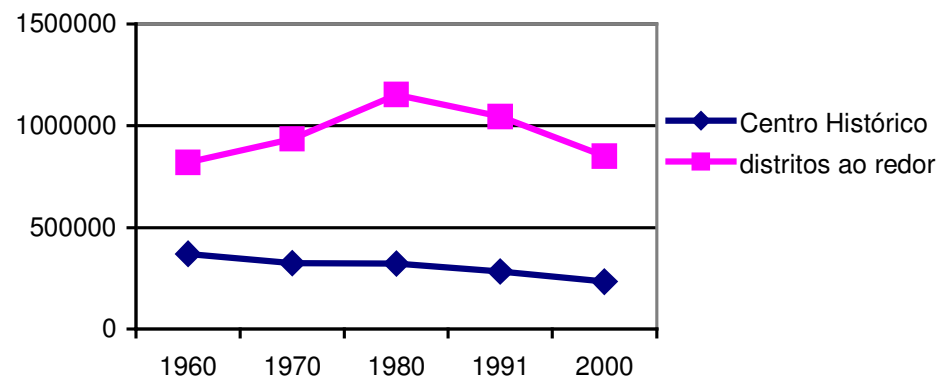

Tabela 3.1. Evolução da população do Centro Expandido Fonte: PMSP, 1975/76; Rolnik, R. et al., 1991; SEMPLA; IBGE, 2000.

\begin{tabular}{|c|c|c|c|c|c|}
\hline centro histórico & 1960 & 1970 & 1980 & 1991 & 2000 \\
\hline Sé & 8880 & 8049 & 8207 & 5795 & 14227 \\
\hline Barra Funda & 32454 & 29762 & 30685 & 25680 & 11708 \\
\hline Belém & 63153 & 52238 & 49273 & 43746 & 35582 \\
\hline Bom Retiro & 26457 & 25606 & 25068 & 19283 & 19080 \\
\hline Brás & 63971 & 54391 & 48588 & 40313 & 19182 \\
\hline Cambuci & 49900 & 48600 & 53590 & 48258 & 26675 \\
\hline Pari & 35000 & 30693 & 27748 & 21899 & 7736 \\
\hline República & ------ & ------ & ------ & ------ & 41978 \\
\hline Mooc & 42792 & 35298 & 36175 & 41314 & 56381 \\
\hline Santa Ifigênia & 47252 & 38980 & 42551 & 36341 & ----- \\
\hline total & 324567 & 286607 & 281314 & 248279 & 234549 \\
\hline \multicolumn{6}{|l|}{ distritos ao redor } \\
\hline Consolação & 51698 & 62226 & 72374 & 65009 & 51174 \\
\hline Alto d & ------- & ------ & ------- & ------ & 38323 \\
\hline Lapa & 105995 & 122512 & 135515 & 120794 & 56151 \\
\hline Liberd & 55873 & 59790 & 73383 & 66110 & 53930 \\
\hline Moema & ------- & ------- & ------- & ------- & 71148 \\
\hline Bela Vista & 57825 & 61192 & 79367 & 65521 & 58472 \\
\hline Perdizes & 91310 & 100161 & 127935 & 119269 & 99178 \\
\hline Pinhei & 36201 & 44080 & 47129 & 40070 & 61377 \\
\hline Jardin & 80173 & 91927 & 116450 & 106327 & 77584 \\
\hline Santa Cecília & 60501 & 67899 & 84956 & 78637 & 67010 \\
\hline Itaim B & ------- & ------ & ------ & ------ & 73280 \\
\hline Vila Leopoldina & ------- & ------ & ------ & ------ & 26042 \\
\hline Indianópolis & 53303 & 70721 & 82658 & 84133 & ------ \\
\hline Aclimação & 44230 & 49058 & 55364 & 52112 & ------- \\
\hline Jardi & 42683 & 47197 & 55291 & 48129 & ------- \\
\hline Cerque & 32040 & 43616 & 65447 & 57032 & ------ \\
\hline Vila Mad & 30112 & 33825 & 48296 & 43147 & ------ \\
\hline Vila Mariana & 76899 & 80919 & 108282 & 99142 & 116772 \\
\hline total & 818843 & 935123 & 1152447 & 1045432 & 850441 \\
\hline total geral & 1143410 & 1221730 & 1433761 & 1293711 & 1084990 \\
\hline
\end{tabular}

${ }^{59}$ Esta avenida não faz parte da área considerada como Centro Expandido neste estudo.

${ }^{60}$ Lembramos que nas tabelas e gráficos deste capítulo, vale a observação feita no Capítulo 1, p.14 sobre a consideração de dois grupos formando o Centro Expandido: "centro histórico e "distritos ao redor" visando compatibilizar os dados de diferentes órgãos. 
Com exceção do pico de crescimento demonstrado no censo de 1980 para os distritos ao redor do antigo centro, fica evidente a tendência de evasão da população de forma gradativa nas décadas de 70 e 80 e com grande ênfase nos anos 90; os motivos diversos que induziram essa reação, entre eles, o baixo preço de terrenos na periferia, suplantaram importantes facilidades proporcionadas pela região, como a proximidade de pólos empregatícios e presença de serviços.

\section{$\underline{\text { Renda Mensal }}$}

O chamado Centro Histórico apresenta menor concentração de renda quando comparado com os distritos ao redor; mesmo assim, a maioria dos distritos são considerados de classe média, segundo a Sempla, somente a Sé e o Belém têm condição sócioeconômica baixa.

Já a região ao redor, reúne os maiores índices de renda mensal do Município. 0s distritos do Alto de Pinheiros, Moema, Jardim Paulista, Itaim Bibi, Pinheiros, Perdizes e Vila Mariana, estão no grupo de condição socioeconômica alta, confirmando a característica da região de constituir a área mais rica da cidade.

Tabela 3.2. Evolução da renda mensal no centro expandido Fonte: PMSP, 1975/76; Rolnik et al., 1991; Sempla; IBGE, 2000.

\begin{tabular}{|c|c|c|c|c|}
\hline centro histórico & de 5 a $10 \mathrm{SM}$ & de 10 a $15 \mathrm{SM}$ & de 15 a $21 \mathrm{SM}$ & $\begin{array}{l}\text { superior a } 21 \\
\text { SM }\end{array}$ \\
\hline $\begin{array}{l}\text { Sé } \\
\text { Barra Funda } \\
\text { Belém } \\
\text { Bom Retiro } \\
\text { Brás } \\
\text { Cambuci } \\
\text { Pari } \\
\text { República* } \\
\text { Mooca }\end{array}$ & $\begin{array}{l}\text { década } 60 / 70 / 80 / 90 \\
\text { década } 60 / 70 / 80 \\
\text { década } 60 / 70 / 80 / 90 \\
\text { década } 60 / 70 / 80 / 90 \\
\text { década } 60 / 70 / 80 / 90 \\
\text { década } 60 / 70 / 80 / 90 \\
\text { década } 60 / 70 / 80 / 90 \\
\text { década } 60 / 70 / 80 / 90\end{array}$ & década 90 & & \\
\hline \multicolumn{5}{|l|}{ distritos ao redor } \\
\hline $\begin{array}{l}\text { Consolação } \\
\text { Alto de Pinheiros* } \\
\text { Lapa } \\
\text { Liberdade } \\
\text { Moema** } \\
\text { Bela Vista } \\
\text { Perdizes } \\
\text { Pinheiros } \\
\text { Jardim Paulista } \\
\text { Santa Cecília } \\
\text { Itaim Bibi** } \\
\text { Vila Leopoldina* } \\
\text { Indianópolis*** } \\
\text { Vila Mariana }\end{array}$ & $\begin{array}{l}\text { década } 60 / 70 / 80 \\
\text { década } 60 / 70 / 80\end{array}$ & $\begin{array}{l}\text { década } 90 \\
\text { década } 90 \\
\text { década } 60 / 70 / 80 / 90 \\
\text { década } 60 / 70 / 80 \\
\text { década } 60 / 70 / 80 \\
\text { década } 60 / 70 / 80 / 90 \\
\text { década } 90 \\
\text { década de } 60 / 70 / 80\end{array}$ & $\begin{array}{l}\text { década } 60 / 70 / 80 / 90 \\
\text { década } 90 \\
\text { década } 90 \\
\text { década } 60 / 70 \\
\text { década } 90 \\
\text { década } 60 / 70 / 80\end{array}$ & $\begin{array}{l}\text { década } 90 \\
\text { década } 90 \\
\text { década } 80 / 90 \\
\text { década } 90\end{array}$ \\
\hline
\end{tabular}

* sem dados específicos para décadas anteriores

** considerando para as décadas anteriores a 90 os dados de Indianópolis

*** dados da década de 90 associados aos distritos Moema e Itaim Bibi 


\subsubsection{Ocupação}

Entre as décadas de 60 e 70, a maioria dos distritos ao redor do Centro Histórico, apresentavam crescimento de até 39\%. Já, aqueles da área mais antiga, mostravam imensa redução.

No último decênio, a maior diminuição ocorreu na Barra Funda (densidade atual de 25,6 hab/Ha), embora todos os outros distritos tenham sofrido redução de população. As maiores densidades estão localizadas na Bela Vista (249,6 hab/Ha) e na República $(215,94$ hab/Ha).

Tabela 3.3. Faixas de densidade demográfica segundo os distritos Fonte: PMSP, 1975/76; Rolnik et al., 1991; Sempla; IBGE, 2000.

\begin{tabular}{|c|c|c|c|c|}
\hline centro histórico & até 80 hab/HA & até $150 \mathrm{hab} / \mathrm{HA}$ & $\begin{array}{l}\text { até } 150 \text { a } 250 \\
\text { hab/HA }\end{array}$ & $\begin{array}{l}\text { superior a } \\
250 \text { hab/HA }\end{array}$ \\
\hline $\begin{array}{l}\text { Sé } \\
\text { Barra Funda } \\
\text { Belém } \\
\text { Bom Retiro } \\
\text { Brás } \\
\text { Cambuci } \\
\text { Pari } \\
\text { República* } \\
\text { Mooca } \\
\end{array}$ & $\begin{array}{l}\text { década } 70 / 80 \\
\text { década } 90 \\
\text { década } 70 / 80 / 90 \\
\text { década } 70 / 80 / 90 \\
\text { década } 70 / 80 / 90\end{array}$ & $\begin{array}{l}\text { década } 90 \\
\text { década } 70 / 80 \\
\text { década } 70 / 80 / 90 \\
\text { década } 70 / 80 / 90 \\
\text { década } 70 \\
\text { década } 70 / 80 / 90\end{array}$ & década 80/90 & \\
\hline \multicolumn{5}{|l|}{ distritos ao redor } \\
\hline $\begin{array}{l}\text { Consolação } \\
\text { Alto de Pinheiros* } \\
\text { Lapa } \\
\text { Liberdade } \\
\text { Moema* } \\
\text { Bela Vista } \\
\text { Perdizes } \\
\text { Pinheiros } \\
\text { Jardim Paulista } \\
\text { Santa Cecília } \\
\text { Itaim Bibi* } \\
\text { Vila Leopoldina* } \\
\text { Indianópolis* } \\
\text { Vila Mariana } \\
\end{array}$ & década $70 / 80 / 90$ & $\begin{array}{l}\text { década } 70 / 80 \\
\text { década } 70 / 80 \\
\text { década } 70 \\
\text { década } 70 / 80 / 90 \\
\text { década } 90 \\
\text { década } 70 / 80 / 90 \\
\text { década } 70 / 80 / 90 \\
\text { década } 70 / 80 / 90\end{array}$ & $\begin{array}{l}\text { década 70/90 } \\
\text { década } 90 \\
\text { década } 80 / 90 \\
\text { década 70/80 } \\
\text { década 70/80/90 } \\
\text { década 70/80 } \\
\text { década 70/90 }\end{array}$ & década 90 \\
\hline
\end{tabular}

*dados estimados pela impossibilidade de definir mudança de área ao longo das três décadas de estudo

\section{Densidade Construída}

Este índice reflete a variação da densidade demográfica bem como a concentração de renda, resultando em maior investimento em construção nos bairros de classe média e alta e conseqüente aumento na quota de ocupação por habitante. 
Tabela 3.4. Evolução da densidade construída no centro expandido Fonte: PMSP, 1975/76; Rolnik et al., 1991; Sempla; IBGE, 2000.

\begin{tabular}{|c|c|c|c|c|}
\hline centro histórico & até $20 \mathrm{~m} 2 / \mathrm{hab}$ & 20 a $32 \mathrm{~m} 2 / \mathrm{hab}$ & 32 a $50 \mathrm{~m} 2 / \mathrm{hab}$ & $\begin{array}{l}\text { superior a } 50 \\
\mathrm{~m} 2 / \mathrm{hab}\end{array}$ \\
\hline $\begin{array}{l}\text { Sé } \\
\text { Barra Funda } \\
\text { Belém } \\
\text { Bom Retiro } \\
\text { Brás } \\
\text { Cambuci } \\
\text { Pari } \\
\text { República } \\
\text { Mooca } \\
\text { Santa Ifigênia }\end{array}$ & $\begin{array}{l}\text { década 80/90 } \\
\text { década } 70 / 80 \\
\text { década } 70 \\
\text { década } 80 \\
\text { década } 70 / 90 \\
\\
\\
\text { década } 70\end{array}$ & $\begin{array}{l}\text { década } 80 \\
\text { década } 70 \\
\text { década } 70 / 80 \\
\text { década } 70 / 80 \\
\text { década } 80\end{array}$ & $\begin{array}{l}\text { década } 70 \\
\text { década } 90 \\
\text { década } 90 \\
\text { década } 90 \\
\text { década } 80 \\
\text { década } 90 \\
\text { década } 90 \\
\text { década } 70 / 80 / 90 \\
\text { década } 90 \\
\text { década } 70 / 80 / 90\end{array}$ & \\
\hline distritos ao redor & & & & \\
\hline $\begin{array}{l}\text { Consolação } \\
\text { Alto de Pinheiros } \\
\text { Lapa } \\
\text { Liberdade } \\
\text { Moema } \\
\text { Bela Vista } \\
\text { Perdizes } \\
\text { Pinheiros } \\
\text { Jardim Paulista } \\
\text { Santa Cecília } \\
\text { Itaim Bibi } \\
\text { Vila Leopoldina } \\
\text { Indianópolis } \\
\text { Aclimação } \\
\text { Jardim América } \\
\text { Cerqueira Cesar } \\
\text { Vila Madalena } \\
\text { Vila Mariana }\end{array}$ & década 70/80 & $\begin{array}{l}\text { década } 70 / 80 \\
\text { década } 80 \\
\text { década } 70 \\
\text { década } 80 \\
\text { década } 70 \\
\\
\text { década } 70 / 80 \\
\text { década } 70 \\
\text { década } 70 / 80\end{array}$ & $\begin{array}{l}\text { década } 70 / 80 \\
\text { década } 70 / 80 \\
\text { década } 90 \\
\text { década } 70 / 90 \\
\text { década } 80 \\
\text { década } 70 / 90 \\
\text { década } 80 \\
\text { década } 70 \\
\text { década } 70 \\
\text { década } 70 / 80 / 90 \\
\text { década } 70 \\
\text { década } 90 \\
\text { década } 70 \\
\text { década } 90 \\
\text { década } 70 \\
\text { década } 70 \\
\text { década } 80\end{array}$ & $\begin{array}{l}\text { década } 90 \\
\text { década } 90 \\
\text { década } 90 \\
\text { década } 90 \\
\text { década } 80 / 90 \\
\text { década } 80 / 90 \\
\text { década } 80 / 90 \\
\text { década } 80 / 90 \\
\text { década } 80 / 90 \\
\text { década } 80 / 90 \\
\text { década } 90 \\
\text { década } 90\end{array}$ \\
\hline
\end{tabular}

A evolução ocorrida nessa região, embora tenha contribuído para o processo de evasão da população de menor renda, gerou ao longo do século $\mathrm{XX}$, a concentração de melhorias em vários aspectos, formando um círculo de investimentos e de constante atração de benfeitorias e como consequiência direta a ocupação da área por grupos de melhor poder aquisitivo, sofisticando os usos e o setor imobiliário, como resumimos no esquema seguinte:

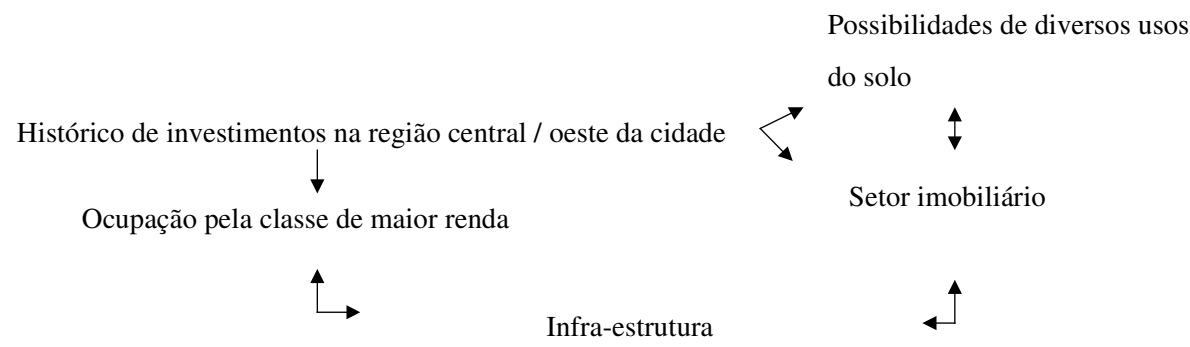

Figura 3.2. Causas e consequiências do desenvolvimento da região Elaboração: Massara, V.M., 2001. 


\subsection{Características gerais da infra-estrutura}

\subsubsection{Coleta de esgotos}

Porcentagem de ligações a rede geral - distritos do centro histórico 1970/91 ${ }^{61}$

Gráfico 3.2.

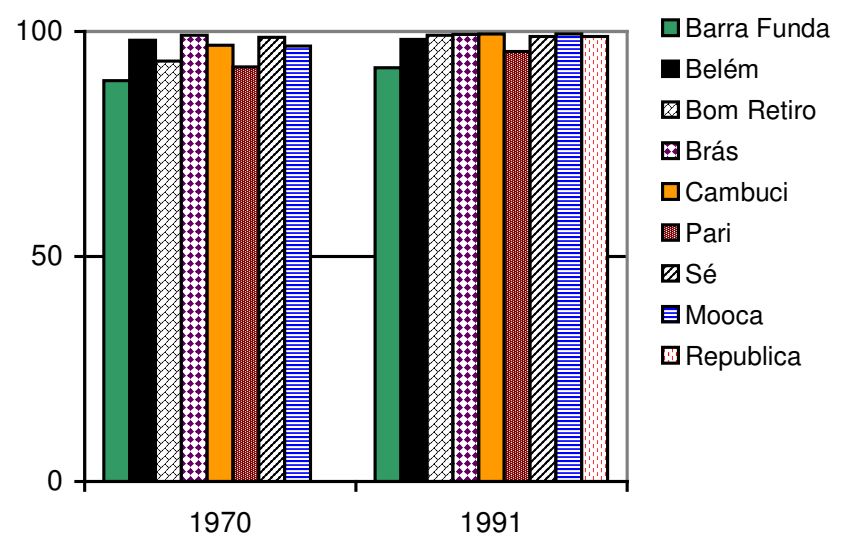

Tabela 3.5.

\section{Porcentagem de ligações a rede geral - distritos ao redor do centro histórico 1970/91 ${ }^{62}$ Gráfico 3.3. Tabela 3.6.}

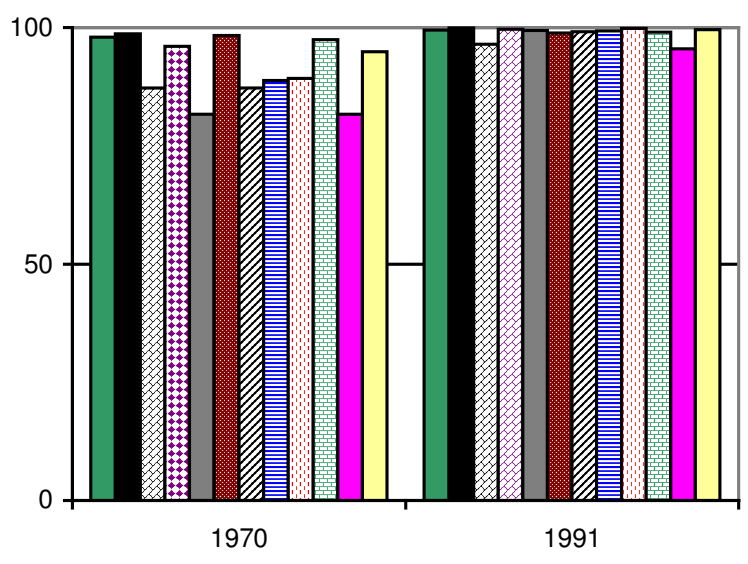

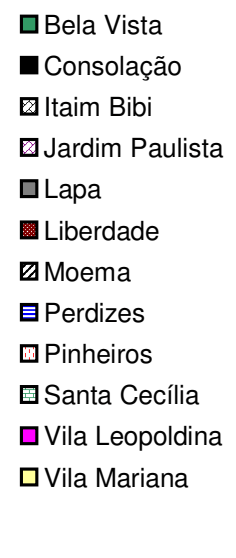

\begin{tabular}{|l|c|c|}
\hline \multirow{2}{*}{ distritos ao redor } & $\mathbf{1 9 7 0}$ & $\mathbf{1 9 9 1}$ \\
\cline { 2 - 2 } & rede geral & rede geral \\
\hline Bela Vista & 98 & 99,5 \\
Consolação & 98,7 & 99,9 \\
Itaim Bibi & (Indianópolis) & 96,5 \\
\cline { 2 - 2 } Jardim Paulista & 96,0 & 99,7 \\
Lapa & 81,7 & 99,4 \\
Liberdade & 98,3 & 98,9 \\
Moema & (Indianópolis) & 99,2 \\
Perdizes & 88,8 & 99,3 \\
Pinheiros & 89,3 & 99,8 \\
Santa Cecília & 97,4 & 99,1 \\
Vila Leopoldina & $($ Lapa) & 95,5 \\
\cline { 2 - 2 } Indianópolis & 87,2 & (Moema e Itaim) \\
\cline { 2 - 2 } Vila Mariana & 94,9 & 99,6 \\
\hline
\end{tabular}

Fonte: IBGE, Censo Predial, 1970; EMPLASA, 1995.

${ }^{61}$ Divisão baseada na combinação entre a delimitação dos Distritos pelo IBGE e pela sinopse dos desmembramentos em distritos e subdistritos no período 1940-1985 apresentada pela EMPLASA, 1986, pg. 23. Notar que em 1970, "Republica" está inserido na região da Sé.

62 Lembramos que os dados do IBGE do ano de 1970, consideram o distrito do Cambuci dividido em Aclimação e Saúde; O distrito do Jardim Paulista em Jardim Paulista, Jardim América e Cerqueira César; Pinheiros em Pinheiros Alto de Pinheiros e Vila Madalena; Lapa em Lapa e Vila Leopoldina; Santa Cecília em Santa Cecília e Santa Ifigênia. Indianópolis é mencionado em região que estimamos ser Moema e parte do Itaim Bibi 
Em $1970^{63}$, os distritos residenciais ao redor da área mais antiga: Perdizes, Itaim Bibi, Moema, Pinheiros, e os industriais: Vila Leopoldina e Lapa (gráfico 3.3), ainda eram menos servidos pela rede do que os do centro histórico. Em 1991, é praticamente desprezível a análise de outros tipos de escoradouro de esgoto. Os valores apresentados mostram que somente nos distritos da Barra Funda, Pari e Itaim Bibi, ainda existe maior utilização de fossa séptica e que esta não ultrapassa 5\% no pior caso (distrito do Pari). Estas informações comparadas àquelas do próximo capítulo, para uma região periférica no mesmo período, enfatizam que em primeiro plano o "centro histórico", seguido dos distritos dos "distritos ao redor", concentram a evolução da infra-estrutura, em parte devido ao histórico de ocupação da cidade e da concentração demográfica e em parte pela concentração de renda, como atrativo ao interesse de provisão dos serviços.

\subsubsection{Abastecimento de água}

A região central é aquela que apresenta os melhores índices de regularidade do serviço. Dados de 1990, mostram quase toda a área considerada como centro expandido com índice superior a 80\%. Pontos isolados correspondentes a áreas de uso público, como parques e a área próxima ao Instituto Modelo de Menores no Catumbi, estão na faixa de regularidade inferior a 67\%. O levantamento de 1999, realizado pela SEMPLA, aponta as regiões dos Jardins a Vila Madalena, Consolação e Aclimação como as mais bem servidas com índice de 100\%. As demais estão na faixa de 90 a $99 \%$. Os gráficos ${ }^{64}$ seguintes organizam o avanço da rede na região, através de dados do IBGE, mostrando desde 1970 sua grande expansão, ressaltando apenas os distritos da Barra Funda, Vila Leopoldina e Itaim Bibi com as menores porcentagens de ligação a rede geral. Os dois primeiros de características eminentemente industriais, por apresentarem infra-estrutura da própria indústria e o terceiro, provavelmente devido ao tamanho de seus lotes e tipo de ocupação, pois vale ressaltar que áreas de maior poder aquisitivo, possuem lotes de maior dimensão, possibilitando o uso de poços e fossas sem que haja contato entre ambos.

${ }^{63}$ O primeiro Censo Predial é de 1970 , impossibilitando que o período anterior a esse ano seja detalhado. 


\subsubsection{Abastecimento de água}

Porcentagem de ligações a rede geral - distritos do centro histórico 1970/91 ${ }^{65}$

Gráfico 3.4.

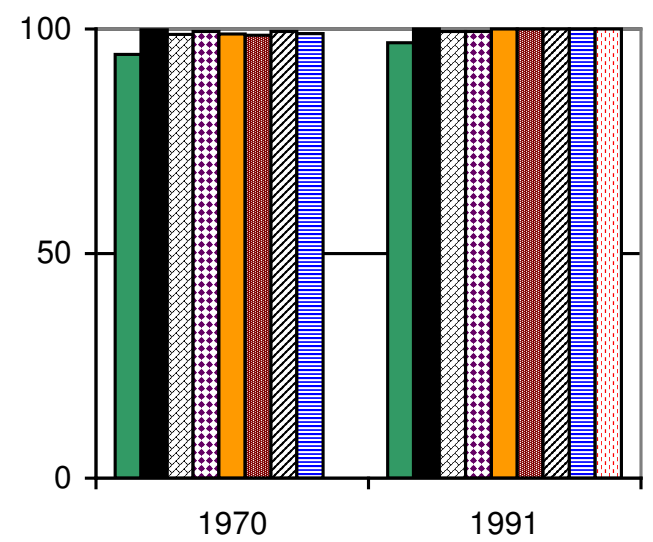

Tabela 3.7.

\author{
aBarra Funda \\ Belém \\ QBom Retiro \\ 田Brás \\ 口Cambuci \\ ⿴囗十 Pari \\ VSé \\ 目Mooca \\ ๑Republica
}

1991

\begin{tabular}{|l|r|r|}
\hline \multicolumn{1}{|c|}{ centro histórico } & \multicolumn{1}{c|}{$\mathbf{1 9 7 0}$} & \multicolumn{1}{c|}{$\mathbf{1 9 9 1}$} \\
\cline { 2 - 3 } & rede geral & rede geral \\
\hline Barra Funda & 94,4 & 97,2 \\
Brlém & 99,8 & 100,0 \\
Bom Retiro & 98,8 & 99,5 \\
Brás & 99,4 & 99,4 \\
Cambuci & 98,9 & 100,0 \\
Pari & 98,6 & 100,0 \\
Sé & 99,5 & 100,0 \\
Mooca & 99,0 & 100,0 \\
República & (Sé) & 100,0 \\
\cline { 2 - 3 }
\end{tabular}

Porcentagem de ligações a rede geral - distritos ao redor do centro histórico 1970/91 ${ }^{66}$

Gráfico 3.5.

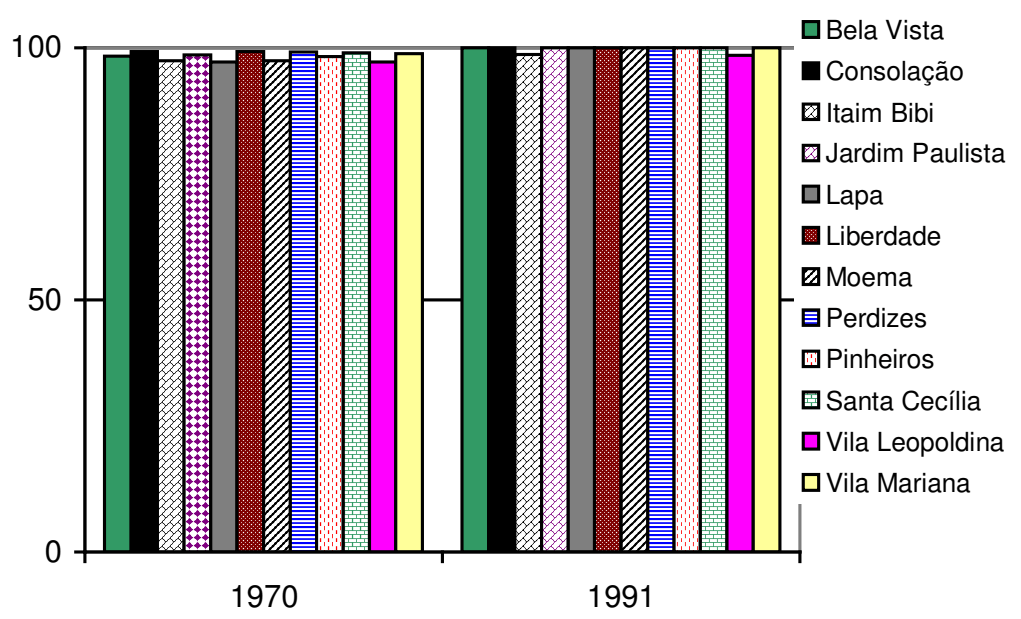

Tabela 3.8.

Fonte: IBGE, Censo Predial, 1970; EMPLASA, 1995.

\begin{tabular}{|l|c|c|}
\hline \multirow{2}{*}{ distritos ao redor } & $\mathbf{1 9 7 0}$ & $\mathbf{1 9 9 1}$ \\
\cline { 2 - 2 } & rede geral & rede geral \\
\hline Bela Vista & 98,4 & 100,0 \\
Consolação & 99,3 & 100,0 \\
Itaim Bibi & (Indianópolis) & 98,7 \\
\cline { 2 - 2 } Jardim Paulista & 98,6 & 100,0 \\
Lapa & 97,2 & 100,0 \\
Liberdade & 99,3 & 100,0 \\
Moema & (Indianópolis) & 100,0 \\
Perdizes & 99,2 & 100,0 \\
Pinheiros & 98,3 & 100,0 \\
Santa Cecília & 99,1 & 100,0 \\
Vila Leopoldina & $($ Lapa) & 98,5 \\
\cline { 2 - 2 } Indianópolis & 97,4 & (Moema e Itaim) \\
\cline { 2 - 2 } Vila Mariana & 98,8 & 100,0 \\
\hline
\end{tabular}

${ }^{64}$ Nestes gráficos apresentamos a porcentagem de ligação a rede geral. O complemento de $100 \%$ corresponde no abastecimento de água ao uso de poços e nascentes e na coleta de esgotos, ao uso de fossas.

${ }^{65}$ Idem 61.

${ }^{66}$ Idem 62. 


\subsubsection{Iluminação Pública}

Referências sobre o processo de expansão das redes, sempre mencionam esta região como sendo prioritária, levando em consideração a importância de suas vias (devido ao volume de tráfego e de pedestres), o tipo de uso do solo e a densidade demográfica.

Os déficits apontados nos anos de 1968 e 1975, correspondem a áreas com concentração de armazéns na região do Pari, Belém e Mooca e áreas com concentração de indústrias como a Barra Funda e Vila Leopoldina.

Embora com alto índice de implantação da rede, a qualidade do serviço não pode ser considerada a ideal.

O menor distanciamento entre postes fornece um melhor rendimento quando comparado as outras regiões da cidade, mas o mapa apresentado na figura 3.10 para o ano de 1997, que traz os pontos com pedido de manutenção ou ligação, demonstra que a densidade de solicitações é menor quando comparada a qualquer área da cidade. Este mapa não diferencia os pedidos de ligação dos de manutenção, mas subentende-se que nessa região, de implantação antiga, a maior parte dos pontos se refere a troca de lâmpadas ou problemas com a fiação e os postes.

Regiões como os Jardins América e Europa, apesar de ótima localização e alto poder aquisitivo, mesmo antes do racionamento de energia elétrica, mostravam sérias deficiências, com muitas ruas totalmente desprovidas de iluminação. A justificativa para este fato é baseada no processo de melhoramento e remodelamento da rede através da troca das lâmpadas de mercúrio - luz branca- pelas amarelas, de sódio, para maior economia.

Levando em consideração todas as observações sobre o histórico de implantação e qualidade do serviço, acreditamos que, mesmo com os problemas descritos, esta região, já há algumas décadas, é a mais bem servida da cidade.

Tabela 3.9. Resumo das condições de Iluminação Pública no período 1968/1997 Região do centro expandido

\begin{tabular}{|r|c|}
\cline { 2 - 2 } \multicolumn{1}{c|}{} & \% Vias iluminadas \\
\hline 1968 & 70,0 \\
1975 & 76,5 \\
1984 & 99,0 \\
1997 & 100,0 \\
\hline
\end{tabular}


Gráfico 3.6. Porcentagem de vias com iluminação pública (em relação ao total de vias) da região do centro expandido ${ }^{67}$

Fonte: PMSP, 1961; PMSP, 1975/76; Sempla, 1985; Ilume, 2001.

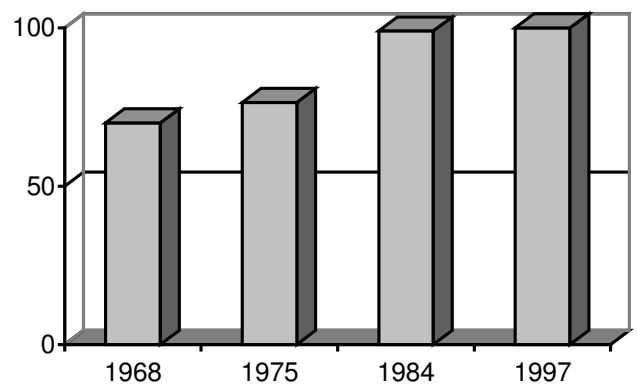

\subsubsection{Energia Elétrica}

Os dois gráficos a seguir, caracterizam a provisão da rede no Centro Expandido em 1970.

Gráfico 3.7. Porcentagem de ligação a rede no Centro Histórico - 1970

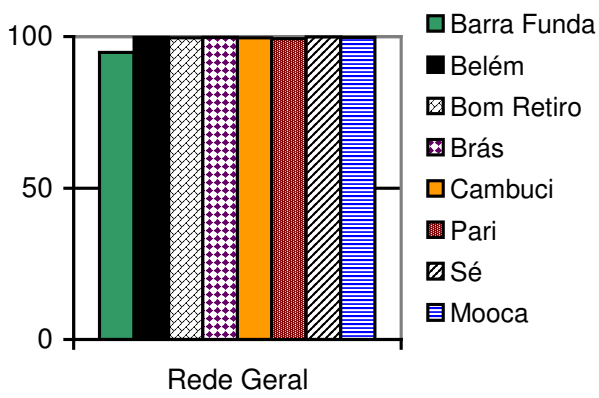

Gráfico 3.8. Porcentagem de ligação a rede nos distritos ao redor -1970

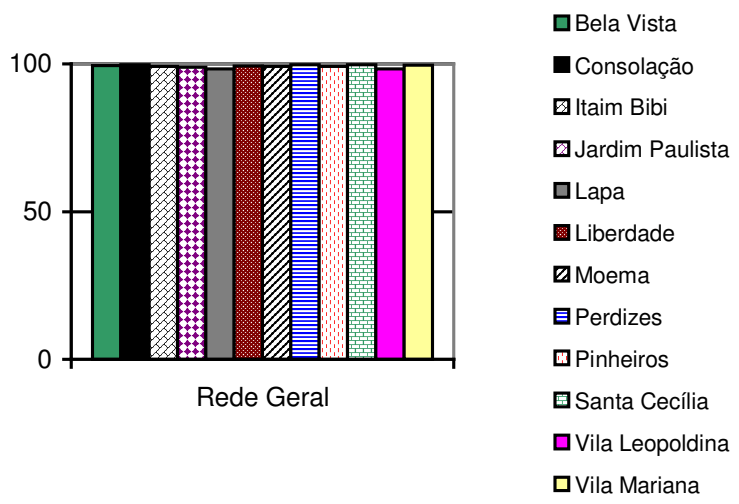

Tabela 3.10. Porcentagem de ligação a rede de energia elétrica - centro expandido - 1970.

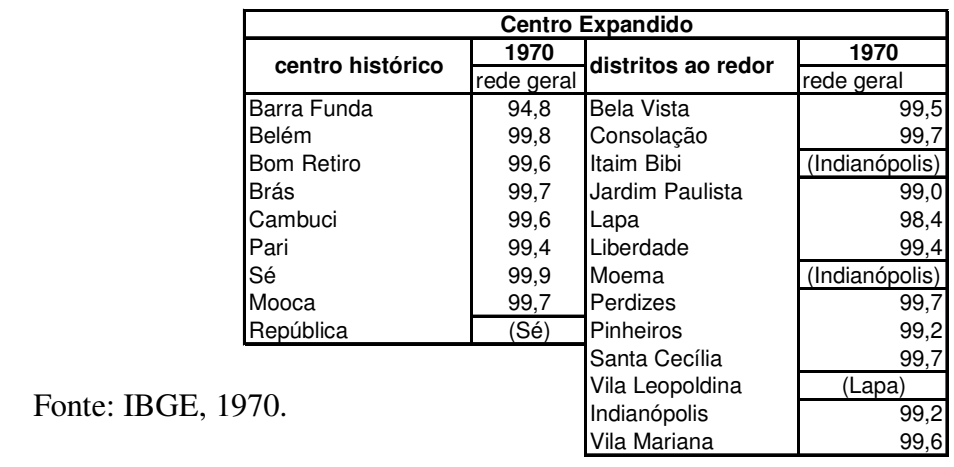

${ }^{67}$ Os dados de 1968 e 1975 foram estimados pela verificação dos mapas sobre a rede (esquemas 3.8 e 3.10). Em 1984, foi utilizada a média entre os valores para as administrações regionais da Sé, Lapa, Pinheiros, Vila Mariana; a Mooca foi desprezada por consideramos pequeno seu território na área do centro expandido. Para 1997, os dados foram obtidos em entrevista de 2000 com a divisão de ampliação dos serviços do Ilume. 
Os gráficos a seguir mostram a divisão apresentada pela Eletropaulo, a partir da década de 80 , fornecendo uma relação entre os tipos de uso do solo e o consumo de energia.

Porcentagem de consumo de energia elétrica por tipo de uso -centro expandido Centro Histórico Gráfico 3.9. Tabela 3.11.

Distritos ao redor

Gráfico 3.10.
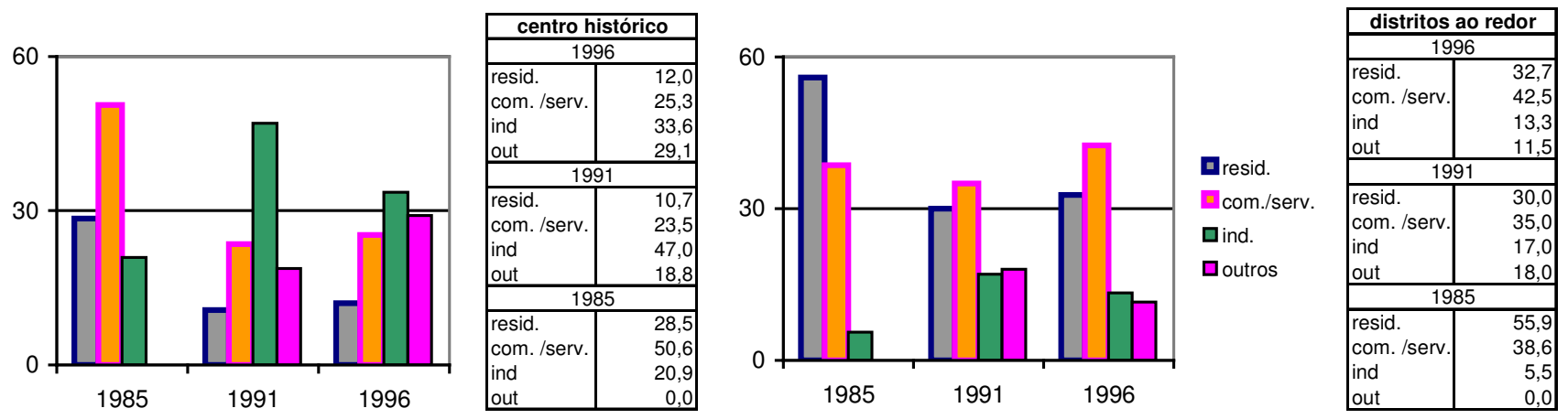

Fonte: EMPLASA, 1986; 1994; TOLEDO SILVA, 2000.

A característica industrial da região ao longo da estrada de ferro é mantida e concentrada principalmente nos distritos de centro histórico (Brás, Barra Funda, Bom Retiro, Mooca, Cambuci) e nos distritos ao redor (Lapa e Vila Leopoldina) embora venha diminuindo e se mesclando ao uso residencial, como mostra o mapa de uso do solo de 1999, produzido pela SEMPLA (figura 3. 9).

A prestação de serviços e comércio, assim como o uso residencial é dominante na área como "distritos ao redor".

Notar a alteração nos gráficos seguintes representada pela divisão intitulada “outros”. Em 1985 essa utilização é quase inexistente, sendo desprezível sua inserção no gráfico. Já em 1991, alguns distritos como a Sé, Barra Funda e Pari, Liberdade e Consolação, apresentam expressivo aumento em parte devido a mudança de usos institucionais para regiões mais centrais e em parte devido a reclassificação do agrupamento que em 1985 considerava o uso governamental na divisão "comércio / serviços". Outra mudança importante, é a transformação de uso residencial em uso misto (mesclando comércio nos bairros dos "distritos ao redor" e indústrias nos bairros do centro antigo). 


\section{Porcentagem de consumo de energia elétrica por tipo de uso - centro histórico}

Gráfico 3.11. 1985

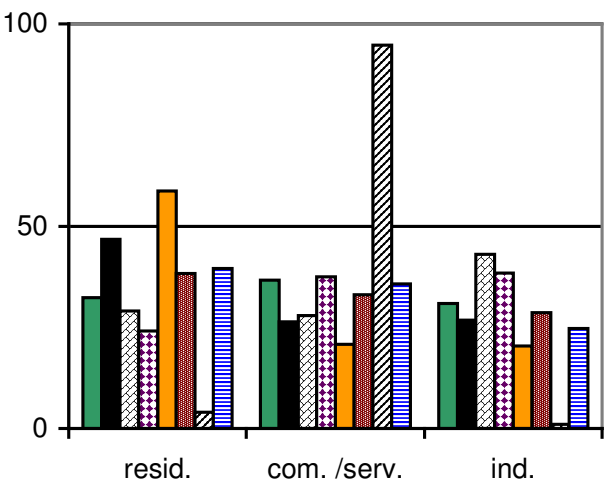

Tabela 3.13. 1985

\begin{tabular}{|c|c|c|c|c|}
\hline \multirow{2}{*}{ Centro Histórico } & \multicolumn{4}{|c|}{1985} \\
\hline & residencial & com/serv. & industrial & outros \\
\hline Barra Funda & 32,4 & 36,7 & 30,8 & 0,1 \\
\hline Belém & 46,8 & 26,4 & 26,8 & 0,0 \\
\hline Bom Retiro & 29,1 & 27,9 & 43,0 & 0,0 \\
\hline Brás & 24,1 & 37,4 & 38,5 & 0,0 \\
\hline Cambuci & 58,7 & 20,8 & 20,4 & 0,1 \\
\hline Pari & 38,2 & 33,0 & 28,8 & 0,0 \\
\hline \multirow{3}{*}{$\begin{array}{l}\text { Sé } \\
\text { Mooca } \\
\text { República }\end{array}$} & 4,1 & 94,8 & 1,1 & 0,0 \\
\hline & 39,5 & 35,8 & 24,6 & 0,1 \\
\hline & \multicolumn{4}{|c|}{ (Sé) } \\
\hline
\end{tabular}

Gráfico 3.12 1991

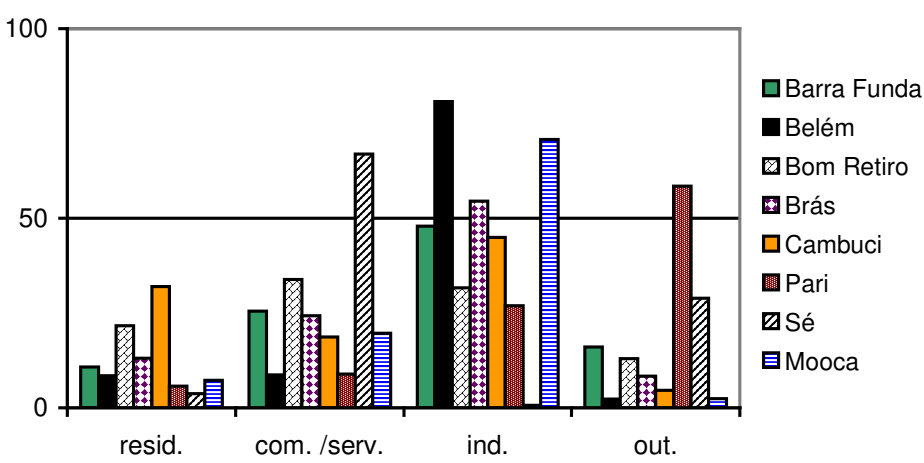

Tabela 3.14. 1991

\begin{tabular}{|l|r|r|r|r|}
\hline \multirow{2}{*}{ Centro Histórico } & \multicolumn{4}{|c|}{$\mathbf{1 9 9 1}$} \\
\cline { 2 - 5 } & residencial & com/serv. & industrial & outros \\
\hline Barra Funda & 74,9 & 18,6 & 5,0 & 1,5 \\
Belém & 79,2 & 15,3 & 4,8 & 0,7 \\
Bom Retiro & 58,3 & 27,3 & 14,0 & 0,4 \\
Brás & 60,5 & 27,2 & 12,1 & 0,2 \\
Cambuci & 86,1 & 10,4 & 3,2 & 0,3 \\
Pari & 69,1 & 21,4 & 8,8 & 0,7 \\
Sé & 24,3 & 72,5 & 1,1 & 2,1 \\
Mooca & 76,0 & 18,5 & 5,2 & 0,3 \\
República & \multicolumn{4}{|c|}{} \\
\cline { 2 - 4 }
\end{tabular}

r tipo de uso - distritos ao redor Gráfico 3.14. 1991

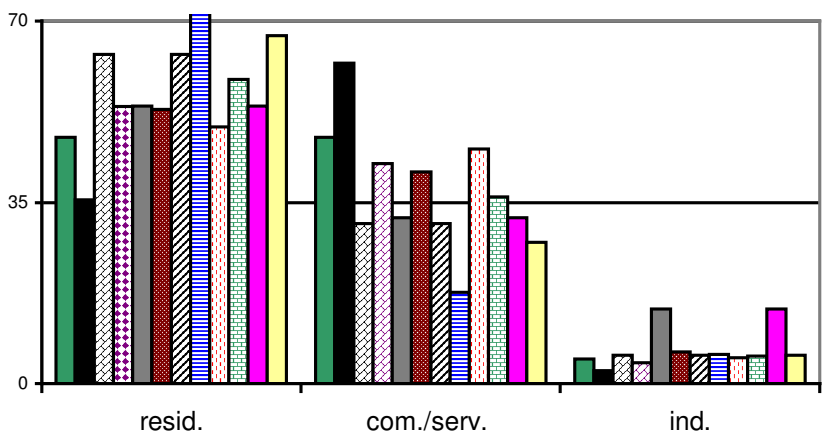

Tabela 3.15. 1985

\begin{tabular}{|l|r|r|r|r|}
\hline \multirow{2}{*}{ Centro Expandidd } & \multicolumn{4}{|c|}{$\mathbf{1 9 8 5}$} \\
\cline { 2 - 5 } & residencial & com/serv. & industrial & \multicolumn{1}{c|}{ outros } \\
\hline Bela Vista & 47,5 & 47,6 & 4,8 & 0,1 \\
Consolação & 35,5 & 61,9 & 2,5 & 0,1 \\
\cline { 2 - 5 } Itaim Bibi & \multicolumn{4}{|c|}{ (Indianópolis) } \\
\cline { 2 - 5 } Jardim Paulista & 53,5 & 42,5 & 4,0 & 0,0 \\
Lapa & 53,6 & 32,0 & 14,4 & 0,0 \\
Liberdade & 53,0 & 40,9 & 6,1 & 0,0 \\
Moema & \multicolumn{5}{|c|}{ (Indianópolis) } \\
\cline { 2 - 5 } Perdizes & 76,6 & 17,6 & 5,7 & 0,1 \\
Pinheiros & 49,6 & 45,3 & 5,0 & 0,1 \\
Santa Cecília & 58,7 & 36,0 & 5,3 & 0,0 \\
Vila Leopoldina & \multicolumn{5}{|c|}{ (Lapa) } \\
\cline { 2 - 5 } Indianópolis & 63,6 & 30,8 & 5,5 & 0,1 \\
Vila Mariana & 67,2 & 27,3 & 5,5 & 0,0 \\
\cline { 2 - 5 } & \multicolumn{5}{|c|}{} \\
\cline { 2 - 5 } & \multicolumn{5}{|c|}{} & \multicolumn{3}{|c|}{} \\
\hline
\end{tabular}

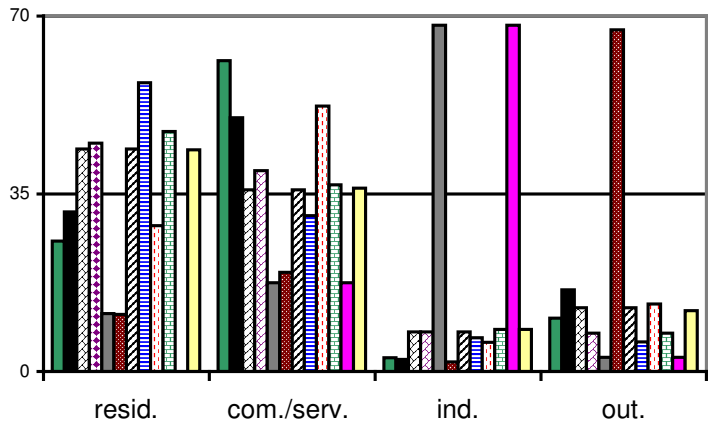

$\square$ Bela Vista - Consolação ㄴ.taim Bibi

๑ Jardim Paulista 口Lapa 늠 Liberdade च Moema 目Perdizes 口Pinheiros 由Santa Cecília $\square$ Vila Leopoldina $\square$ Vila Mariana

Tabela 3.16. 1991

\begin{tabular}{|l|r|r|r|r|}
\hline \multirow{2}{*}{ Centro Expandidd } & \multicolumn{4}{|c|}{$\mathbf{1 9 9 1}$} \\
\cline { 2 - 5 } & residencial & com/serv. & industrial & outros \\
\hline Bela Vista & 80,5 & 18,1 & 0,6 & 0,8 \\
Consolação & 69,9 & 28,8 & 0,4 & 0,9 \\
\cline { 2 - 5 } Itaim Bibi & \multicolumn{4}{|c|}{ (Indianópolis) } \\
\cline { 2 - 5 } Lapa & 80,8 & 15,5 & 3,1 & 0,6 \\
Liberdade & 82,1 & 16,4 & 0,8 & 0,7 \\
Moema & \multicolumn{5}{|c|}{ (Indianópolis) } \\
Perdizes & 90,1 & 8,8 & 0,9 & 0,2 \\
Pinheiros & 74,8 & 23,4 & 1,3 & 0,5 \\
Jardim Paulista & 78,4 & 20,3 & 0,9 & 0,4 \\
Santa Cecília & 88,5 & 10,7 & 0,5 & 0,3 \\
Vila Leopoldina & \multicolumn{5}{|c|}{ (Lapa) } \\
\cline { 2 - 5 } Indianópolis & 84,6 & 14,2 & 1,0 & 0,2 \\
Vila Mariana & 86,0 & 12,6 & 0,9 & 0,5 \\
\hline
\end{tabular}




\subsubsection{Gás canalizado ${ }^{68}$}

O avanço dessa rede até a década de 60 foi grande, permanecendo estagnado até os anos 90, quando a área atendida por média e baixa tensão correspondia aos distritos da Barra Funda, Santa Cecília, Sé, Bela Vista, Liberdade, Aclimação, Cambuci, Santa Efigênia, Pari-Brás, Belenzinho, Mooca, Alto da Mooca, parte do Ipiranga, Vila Mariana, Indianópolis, Jardins, Cerqueira César e Pinheiros.

Os planos de expansão colocados em prática desde 1998, visam suprir toda a região central e encaminhar a tubulação na direção sul e norte (Cap.2, p 64.), indicando que todos os distritos do centro expandido (centro antigo e ao redor) são os prioritários.

\subsubsection{Telefonia}

As primeiras centrais telefônicas foram instaladas no centro antigo nas primeiras décadas do século XX. Em 1940, já eram 7. Este processo desencadeou também neste serviço a concentração de esforços em suprir a demanda dessa área, que na década de 80 , superava o número de 40 terminais a cada 100 hab. ${ }^{69}$ (que comparado as regiões periféricas que apresentavam de 2 a 5 terminais, evidencia a enorme diferença entre regiões). Através de estimativa obtida por dados da Telefonica em 1999, calculamos que este índice supera os 125 terminais por grupo de 100 hab. ${ }^{70}$

\subsubsection{Cabo óptico}

Como as demais, esta rede teve origem no centro antigo, através da implantação nos anos 80 do anel de cabo óptico na região da Luz, com a função de reduzir o diâmetro dos cabos da rede telefônica e depois, para a otimização do uso de computadores, se estendendo por todo o centro expandido. Da mesma forma, a rede para “tv's a cabo" se difundiu rapidamente por essa região, visando usufruir do poder aquisitivo de certos bairros ${ }^{71}$. Embora este serviço esteja bastante expandido em todo o Município, a região central continua sendo a mais bem servida.

\footnotetext{
${ }^{68}$ Idem 35.

${ }^{69}$ Com exceção de áreas da Barra Funda, Pari, Belém que se mantinham na faixa de 30 a 40 terminais a cada 100 habitantes.

${ }^{70}$ Foi considerada a média entre as centrais Benjamin Constant, Consolação, Liberdade, Anhangabau, Brás , Santa Ifigênia, Ibirapuera, Paraíso, Vila Mariana, Itaim Bibi, Jardim, Moema, Lapa, Pinheiros, Vila Madalena, Água Branca, Palmeiras, Perdizes. Lembrando que estes dados são uma estimativa já que os valores de algumas centrais foram deixados em aberto pela Telefonica.

${ }^{71}$ Distritos antigos como a Sé, Bom Retiro e Pari não aparecem na lista da área cabeada.
} 


\subsection{Infra-estrutura e uso do solo ${ }^{72}$ no centro expandido}

\subsubsection{Período 1890-1922}

O primeiro relato sobre melhorias na condição das redes, data de 1879 , quando do assentamento dos canos para abastecimento de água, ligando o manancial da Cantareira ao reservatório da Consolação. ${ }^{73}$

Em 1882 foram entregues ao uso público os chafarizes recém construídos, do Campo da Luz (avenida Tiradentes), Largo São Bento, Largo do Pelourinho (Sete de Setembro), Largo do Guaianazes (Capão Redondo) e Largo Sete de Abril (Praça da República) que junto aos antigos, tentavam suprir a cidade, já que não havia verba disponível para o melhor aproveitamento da única fonte - a Cantareira, alguns quilômetros ao Norte...(MORSE, 1970, p.172).

No ano de 1883, a região da Luz é considerada o "primeiro distrito de esgoto". Boa parte das ruas já era servida com redes desde o centro até proximidades da Rua Tenente Pena (próximo a atual Praça Coronel Prestes). A proximidade da Serra da Cantareira propiciava água de boa qualidade. Em 1889, tem início o incremento da canalização domiciliar para a rede de água da região Sé.

Em 1893, todos os chafarizes foram demolidos, como forma de obrigar os usuários a "comprarem" os serviços da concessionária.

Em 1900, a iluminação elétrica é instalada em alguns pontos do centro, chegando a algumas ruas do Bom Retiro e a região de Campos Elíseos, como também em pontos da Consolação em direção a recém inaugurada Avenida Paulista.

Nesta época, além desse núcleo central, de caráter predominantemente comercial, na direção do Brás e Luz, em função da Estrada de Ferro, tinha início a efetiva ocupação da área como bairro operário, além de pequena concentração de comércio, indústrias e armazéns.

A elite em busca de terrenos mais altos e na promessa de implantação de infra-estrutura no novo loteamento, vai rumo ao Campos Elíseos, bairro aberto em 1879 e praticamente desocupado até 1890 . No período de 20 anos a área recebeu

${ }^{72}$ Os mapas de uso do solo apresentados foram retirados de BARBOSA, E. Evolução do uso residencial na área central, 2001. Recomendamos a consulta a este trabalho que detalha o uso do solo nesta região. 
todos os melhoramentos públicos: iluminação a gás, água, esgoto, arborização e pavimentação das ruas, em 1910 em pleno funcionamento, com infra-estrutura completa, o bairro está no ápice das considerações sobre qualidade de vida. Outro empreendimento de grande porte, foi a abertura da Avenida Paulista em 1891 um dos únicos empreendimentos que podem mencionar a infra-estrutura como atrativo ao incremento do uso do solo. Foi inaugurada já provida de todos os melhoramentos, enquanto suas transversais e paralelas, funcionando como infra-estrutura de apoio, recebiam tudo que não era "digno" da nobre avenida ${ }^{74}$.

Na década de 10, o primeiro acontecimento de vulto no desenvolvimento das redes $^{75}$, foi em 1912, a extensão da rede de coleta de esgotos até o Cambuci e Vila Mariana. Foram iniciadas as redes de Perdizes e parte do Ipiranga, finalizadas em 1914. No ano seguinte, Barra Funda e Bom Retiro são servidos e tem início as obras nos bairros da Água Branca, Lapa e Santana.

Na mesma época (1912), o abastecimento de água, também teve boa expansão embora seja notório que o serviço não conseguia alcançar o ritmo acelerado do crescimento urbano. Bairros como Cambuci, Mooca, Bom Retiro, Barra Funda, possuíam a rede mas com grandes problemas de regularidade. Outras áreas como Vila Mariana, Perdizes, Água Branca e Belenzinho eram totalmente desprovidos. A iluminação alcançava alguns bairros distantes como a Água Branca, Lapa e Ipiranga, mas a preferência para instalação da rede era o centro e as ruas dos melhores bairros.

${ }^{73}$ Esta experiência localizada não traduz a situação do abastecimento nessa época. Como explicamos a seguir, o comum era o uso (e construção) de chafarizes públicos, o que não permitia máximo aproveitamento do manancial da Cantareira.

${ }^{74}$ Encontramos um relato interessante sobre essa época e a região, mencionado por REALE (1982) descrito por GATTAI (1979, p.43): “A Alameda Santos, vizinha pobre da Paulista, herdava tudo aquilo que pudesse comprometer o conforto e status dos habitantes da outra, da vizinha famosa. Os enterros, salvo raras exceções, jamais passavam pela Avenida Paulista. Eram desviados para a Alameda Santos nela desfilavam todos os cortejos fúnebres que se dirigiam ao Cemitério do Araçá, não muito distante dali. Rodas de carroças e patas de burros jamais tocaram no bem cuidado calçamento da Paulista. Tudo pela Alameda Santos! Nem as carrocinhas da entrega do pão, nem os burros da entrega do leite, com seus enormes latões pendurados em cangalhas, um de cada lado, passando pela manhã muito cedo, tinham permissão de transitar pela Avenida."

${ }^{75} \mathrm{O}$ mapeamento das redes nesse período (figura 3.4) não detalha a evolução descrita na década de 10, mas através dessa narrativa podemos concluir que essa época marcou a grande evolução dos serviços, expressa na figura 3.6 para o próximo período (1922-1952) nos mapas de 1928. 


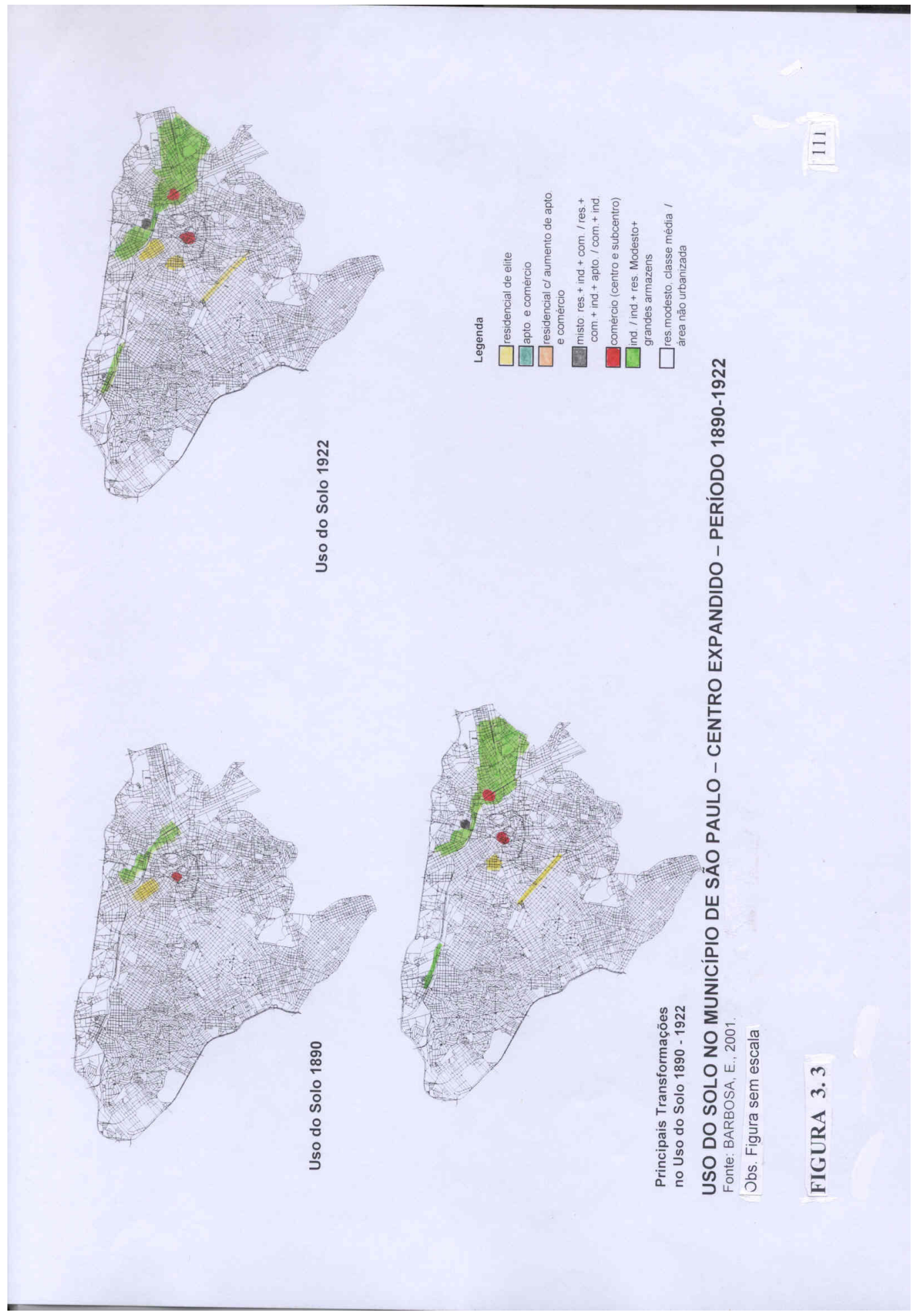

Figura 3.3. Uso do solo no centro expandido 1890-1922 (original em cópia colorida) 


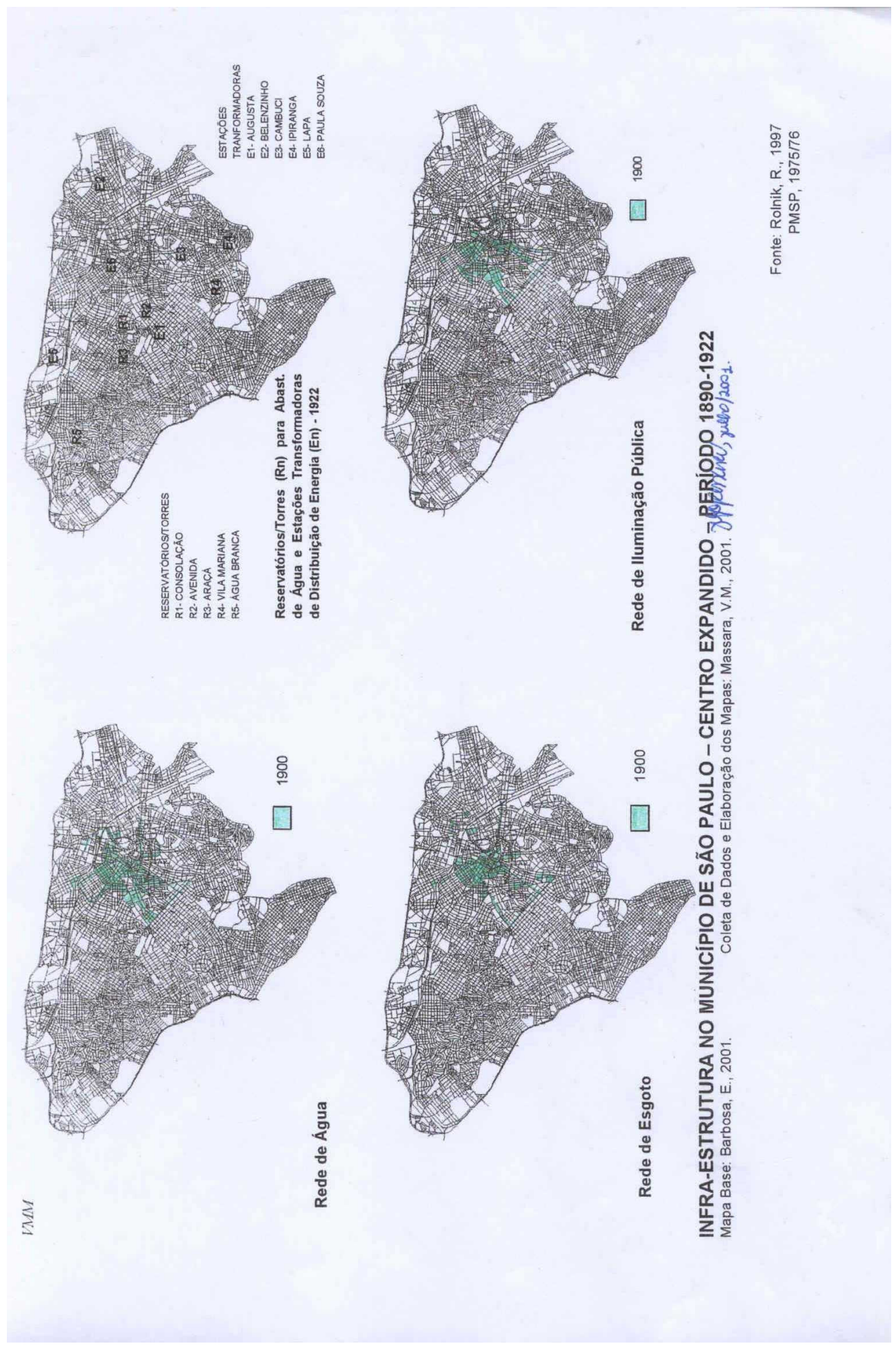

Figura 3.4. Infra-estrutura no centro expandido 1890-1922 (original em cópia colorida) 
Simultaneamente, os bairros vão sendo ocupados. A área residencial de elite chega a Higienópolis, as indústrias avançam ao redor da Estrada de ferro, no Pari, Belém, Brás e Mooca: fábricas de bebidas (Antarctica), tecelagens, calçados e no sentido oposto na Lapa de Baixo : várias vidrarias, entre elas a Santa Marina. Surge um núcleo comercial expressivo no Brás (entre as Avenidas Bresser e Celso Garcia).

\subsubsection{Período 1922-1952}

O ano de 1922 marca a difusão da energia elétrica como fonte para iluminação pública.

Aproveitando as facilidades construtivas para expansão das redes, tem início o loteamento da área abaixo da Rua Estados Unidos e delimitada pelas Avenidas Nove de Julho e Brigadeiro Luiz Antonio, como a Avenida Paulista, servido por todos os melhoramentos. As ruas Pamplona e Augusta aparecem como importantes corredores de comércio sofisticado.

Na direção noroeste, a mesma Companhia, inicia em 1920 o loteamento do Alto da Lapa e Bela Aliança, na mesma área com padrões inferiores, surge a Vila Leopoldina, que ao longo desse período se transforma em grande área industrial no ramo metalúrgico.

Mesmo sem informações sobre a precisa data de implantação das redes entre 1900 e 1928, fica subentendido que os melhoramentos nos bairros operários, foram incrementados na década de 20.

Em 1929, a região de Pinheiros recebe água canalizada. Nos anos seguintes até 1942, Perdizes, Vila Madalena, Aclimação e Parque da Mooca. A situação da rede de coleta de esgotos alcança esse perímetro dez anos mais tarde (1952) como mostra a figura 3.6.

Na expansão sul da cidade - ínfima nesse período-, a região do Itaim Bibi, loteada em 1920, sem nenhum plano urbanístico, ainda em 1951 utilizava poços, em áreas mais altas como as Ruas Floriano Peixoto, Pedroso de Albuquerque, Renato Paes de Barros e Clodomiro Amazonas a água era de boa qualidade e as fossas funcionavam a contento; já nas regiões baixas para evitar a contaminação, as fossas eram limpas e desinfetadas a cada quinze dias. 
Estes dois períodos $(1890-1922 ; 1922-1952)$, constituem os anos de maior evolução das redes, embora fique claro que em apenas três casos a pré - existência da infra-estrutura estimulou o uso do solo: Avenida Paulista, parte da Vila América ${ }^{76}$ e Alto da Lapa, atraindo o uso residencial de elite (figura 3.5).

Em outros casos, mesmo sendo ocupado pela classe de maior renda, a implantação das redes foi conseqüência da ocupação como em Higienópolis e Campos Elíseos.

A restrição a instalação de casas comerciais nos Jardins, limitando as ruas de comércio a Pamplona e Augusta, a instalação de linhas de bonde (1910 - bonde da Rua Augusta e 1924 - bonde do Jardim Paulista), somada a reunião de colégios de renome, assim como a instalação de pólos culturais (como o Museu de Arte de São Paulo - 1950) contribuiu para a ocupação residencial de maior poder aquisitivo.

Nestas décadas outros núcleos comerciais são criados: Lapa (região da Rua Guaicucus com Gavião Peixoto e Nossa Senhora da Lapa) e Pinheiros (Rua Pedroso de Morais com Avenida Brig. Faria Lima).

O processo de verticalização da cidade cria uma área residencial mista com comércio ao redor do antigo centro: Pacaembu, Higienópolis, Santa Cecília, Campos Elíseos (já decadente) e Consolação.

O desenvolvimento de funções industriais incentivada pela Estrada de Ferro, e também pela construção das marginais Pinheiros e Tietê, consolidou a Lapa, Barra Funda, Belém, Pari, Brás e Mooca, como bairros tipicamente operários, originando regiões de uso misto (comércio, indústria e residências), principalmente nos últimos três bairros.

${ }^{76}$ Conforme REALE (1982), o perímetro da Vila América corresponde ao atual Jardim Paulista ou a área de Cerqueira César mais as alamedas paralelas e transversais a Avenida Paulista. 


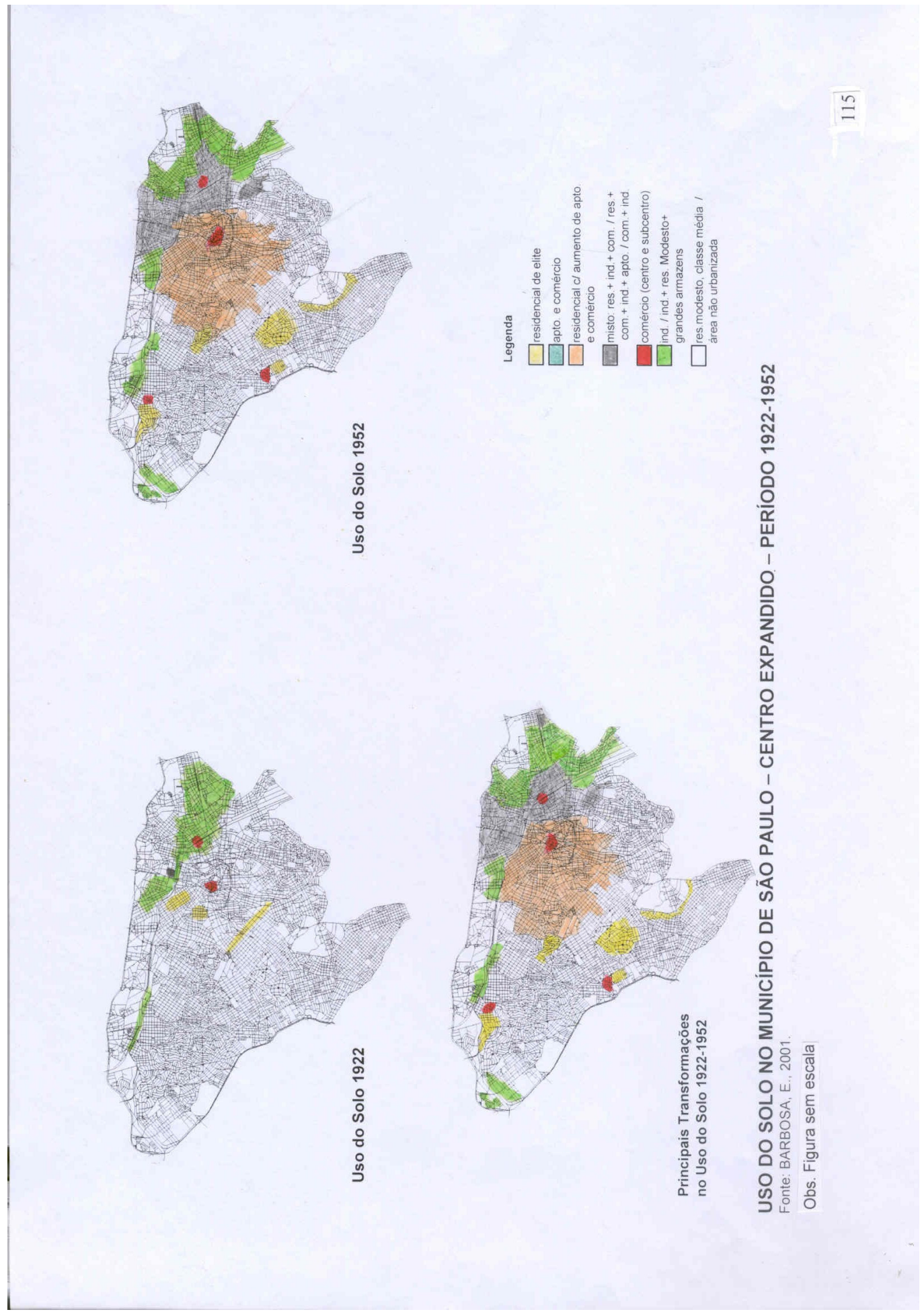

Figura 3.5. Uso do solo no centro expandido 1922-1952 (original em cópia colorida) 

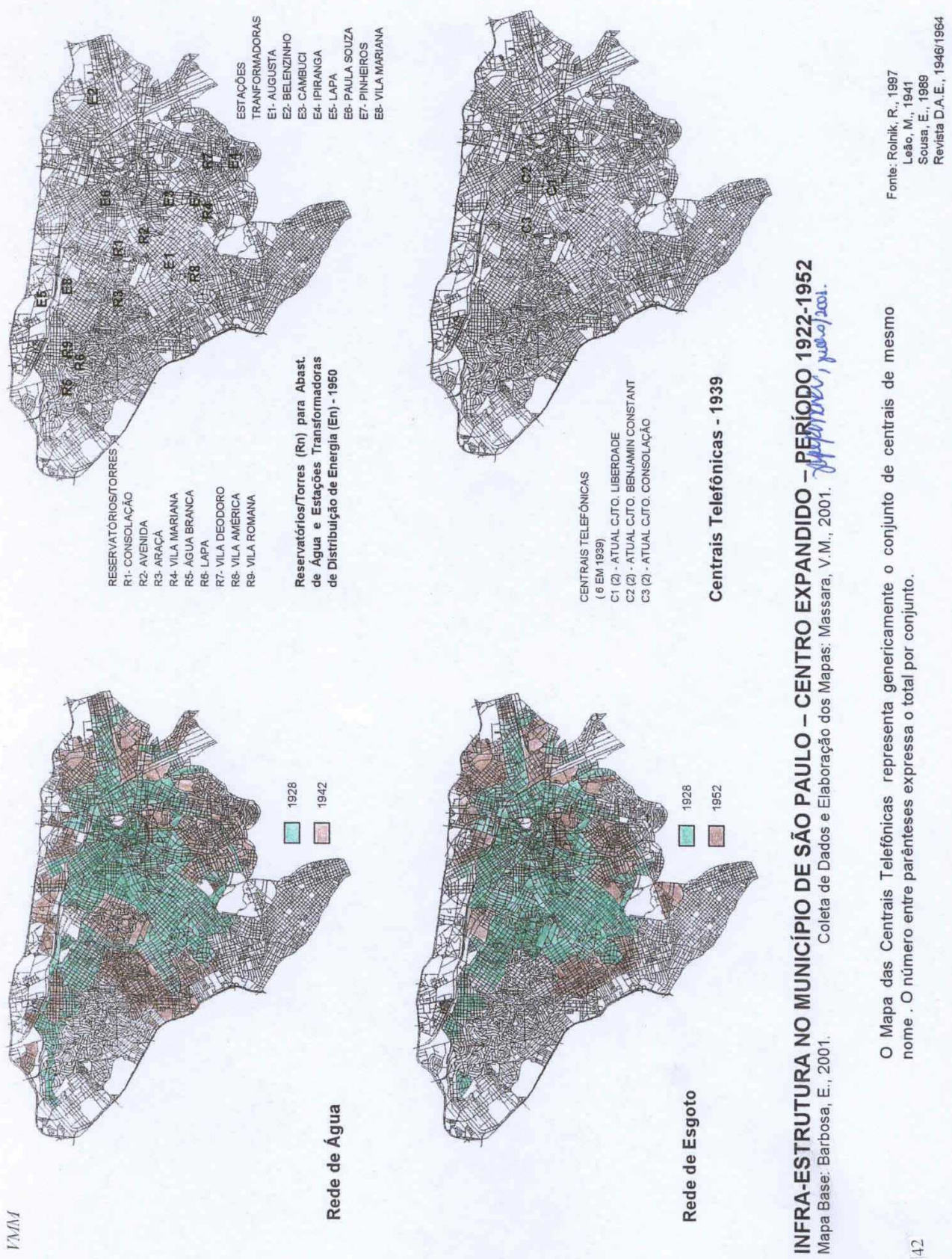

Figura 3.6. Infra-estrutura no centro expandido 1922-1952 (original em cópia colorida) 


\subsubsection{Período 1952-1972}

Este período concentra a cobertura de "vazios" em regiões como o Sumaré em direção a Vila Madalena, pontos dispersos da Barra Funda e pontos da Aclimação até a Vila Mariana. As áreas servidas por abastecimento de água e iluminação pública são aproximadamente coincidentes.

Os mapas de 1958 e 1968 mostram pouca evolução em direção ao Itaim Bibi e Planalto Paulista e em parte da Vila Leopoldina e Alto de Pinheiros, de ocupação mais recente. No final desse período pode-se afirmar que é mínima a deficiência da região no tocante aos dois serviços.

A rede de coleta de esgotos evidencia certa diferença em relação as redes descritas anteriormente. Embora em 1928, mostrasse áreas com maior avanço ${ }^{77}$ do que a rede de água, somente na década de 60, enfatizou a expansão na direção sul (Itaim e Moema). Também a rede de gás demonstrada no mapa de 1958, se mantem praticamente a mesma passados dez anos, cobrindo a área central (até a Mooca) e estendendo-se em direção sudoeste até os bairros de Jardins América e Europa e Jardim Paulista e como veremos adiante, até a evolução proposta no projeto do final do anos 90, pouca alteração ocorre nesse âmbito nas duas décadas seguintes.

Simultanemente, o perfil do uso residencial do solo sofre as transformações oriundas do processo de verticalização iniciado nos anos 60.

A inauguração de Shopping Centers, como o Shopping Iguatemi - o primeiro da América Latina - inicia uma nova fase do comércio. Ao mesmo tempo, outros subcentros são criados e se inicia a popularização do comércio central.

Em 1966, a construção do Ceasa (atual Ceagesp), além de favorecer o abastecimento da cidade, define a região entre as Vilas Leopoldina e Hamburguesa como área de uso misto com concentração de armazéns e residencial modesto, além de indústrias já estabelecidas no período anterior.

Também no início desse período começa a implantação da linha Norte-Sul do Metro que irá influenciar modificações em boa parte da região em estudo, ressaltando a importância da localização e da acessibilidade como determinantes na escolha de usos e decisão sobre projetos no campo do sistema viário e dos meios de transporte.

\footnotetext{
${ }^{77}$ Ver lei descrita no Cap.2, nota 25, incentivando primeiro a execução da rede coletora de esgotos.
} 


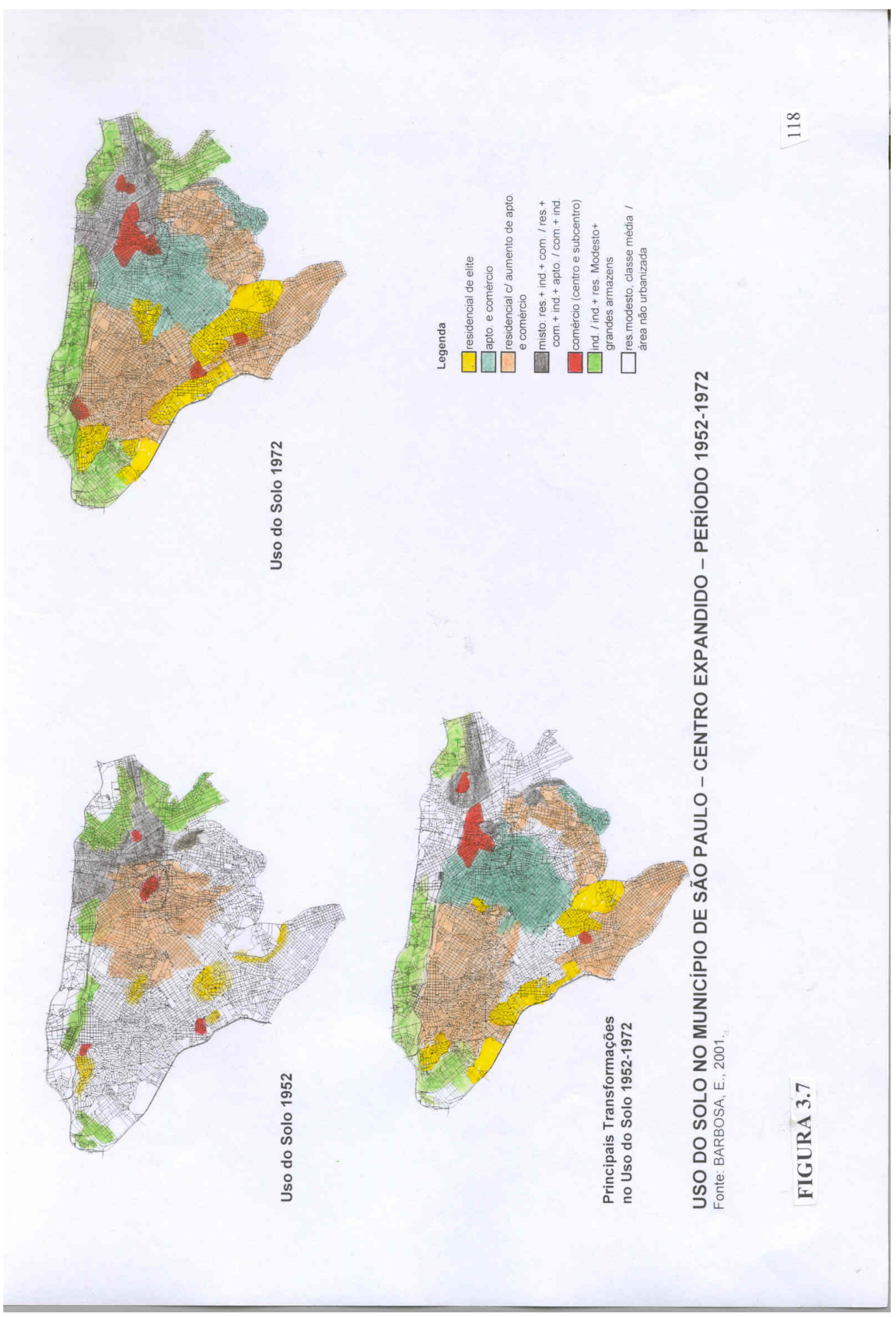

Figura 3.7. Uso do solo no centro expandido 1952-1972 (original em cópia colorida) 

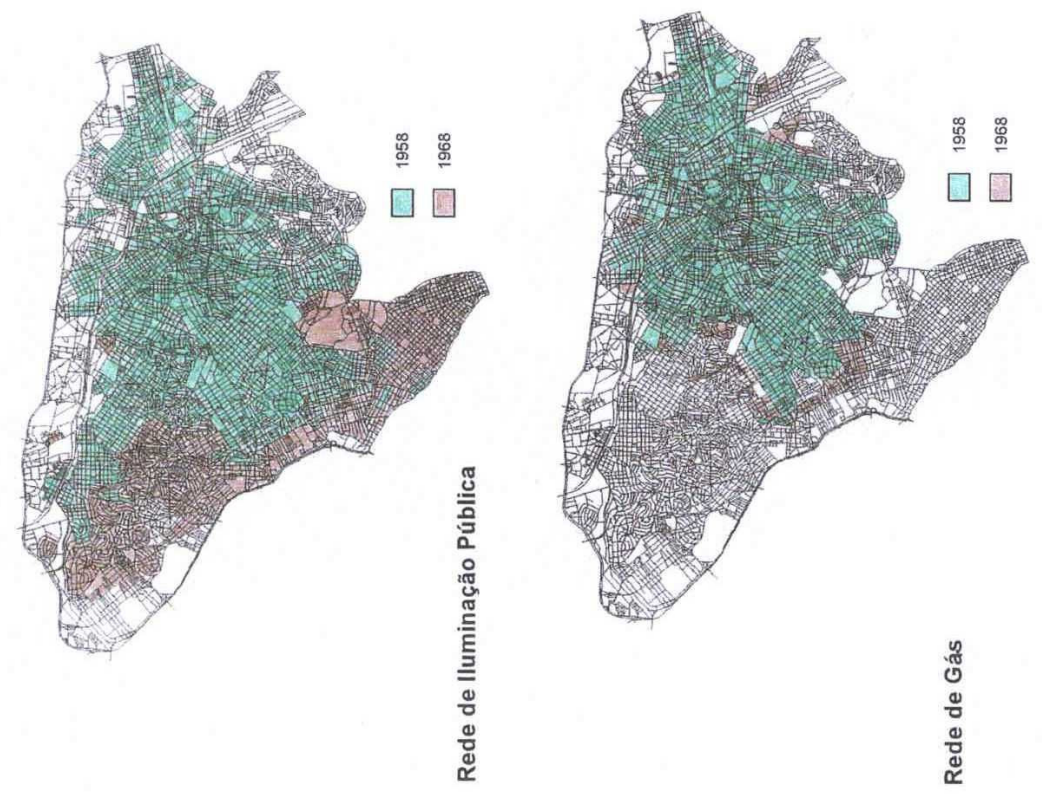

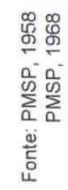
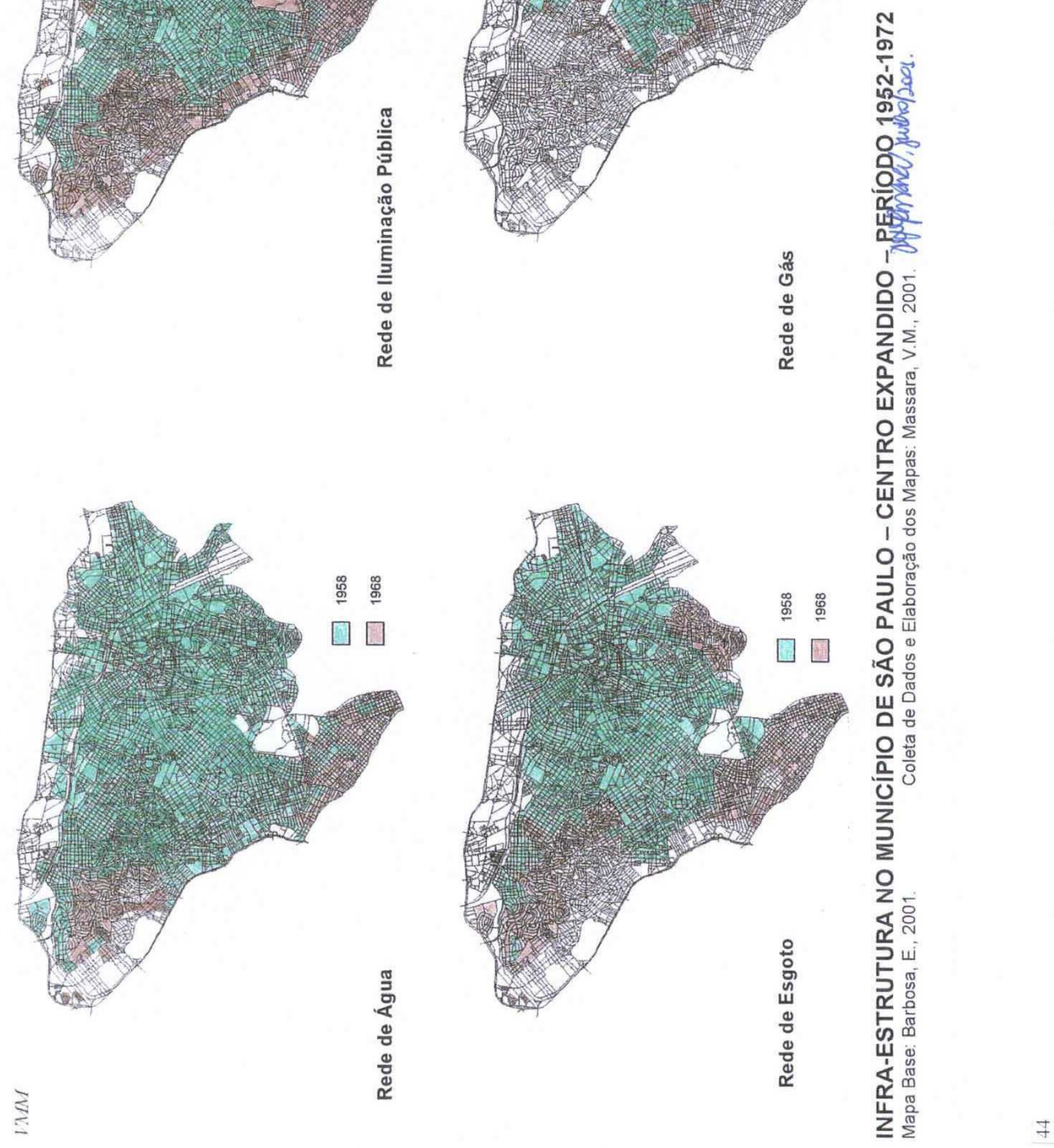

Figura 3.8. Infra-estrutura no centro expandido 1952-1972 (original em cópia colorida) 


\subsubsection{Período 1972-1999}

Esse período marca a consolidação das redes de infra-estrutura, com praticamente toda a área servida por abastecimento de água e iluminação pública. Déficits pontuais são encontrados nas regiões da Barra Funda, Mooca, Lapa de Baixo e Vila Leopoldina. Ainda em 1975, na área central, os problemas com rede de coleta de esgotos estavam localizados em áreas próximas à Marginal do Tietê em áreas de ocupação desordenada, entre a Avenida Rudge e o leito do rio.

A rede de gás, pouco expandida fora do Centro Antigo e Jardins, se estende a região de Pinheiros ao longo das Avenidas Brigadeiro Luiz Antonio, Nove de Julho, Rebouças e ruas comerciais como a Joaquim Floriano e Pedroso de Moraes. Na Lapa, uma área inexpressiva entre as avenidas Francisco Matarazzo, Sumaré e Pacaembu é beneficiada.

Embora a área seja totalmente servida por iluminação pública, os pontos com pedido de manutenção são inúmeros, conforme mapeamento do Ilume de 1997.

Segundo a SABESP, atualmente a região é $100 \%$ servida por saneamento. Já a rede de gás está em processo de expansão em direção a Lapa e a Santo Amaro.

As mudanças no uso do solo, principalmente quanto ao processo de desindustrialização, transformaram toda a região ao longo da ferrovia em uso misto.

Vários centros comerciais se expandiram, como o antigo centro se estendendo até a Avenida Paulista, os centros do Brás, Lapa e da Avenida Brigadeiro Faria Lima.

Com exceção ao Alto da Lapa, parte dos Jardins América e Europa e da região do Itaim Bibi em direção ao Ibirapuera, as áreas eminentemente residenciais de elite cedem espaço a regiões com grande concentração de edifícios e comércio.

Como mostra o mapa de 1999 (figura 3.9) extraído de estudos da SEMPLA (2000, encarte do vol.2), com exceção as áreas mais nobres, todas as outras apresentam ocupação mesclada com outros tipos de uso. A predominância de prédios na área abaixo da estrada de ferro $^{78}$ se mistura a áreas de pequeno comércio, resumindo a ocupação em três grandes grupos: comércio e prestação de serviços; uso residencial, industrial e comercial (um tipo de uso misto) e residencial e comercial (outro tipo de uso misto).

\footnotetext{
${ }^{78}$ Considerando a orientação Norte do Município.
} 


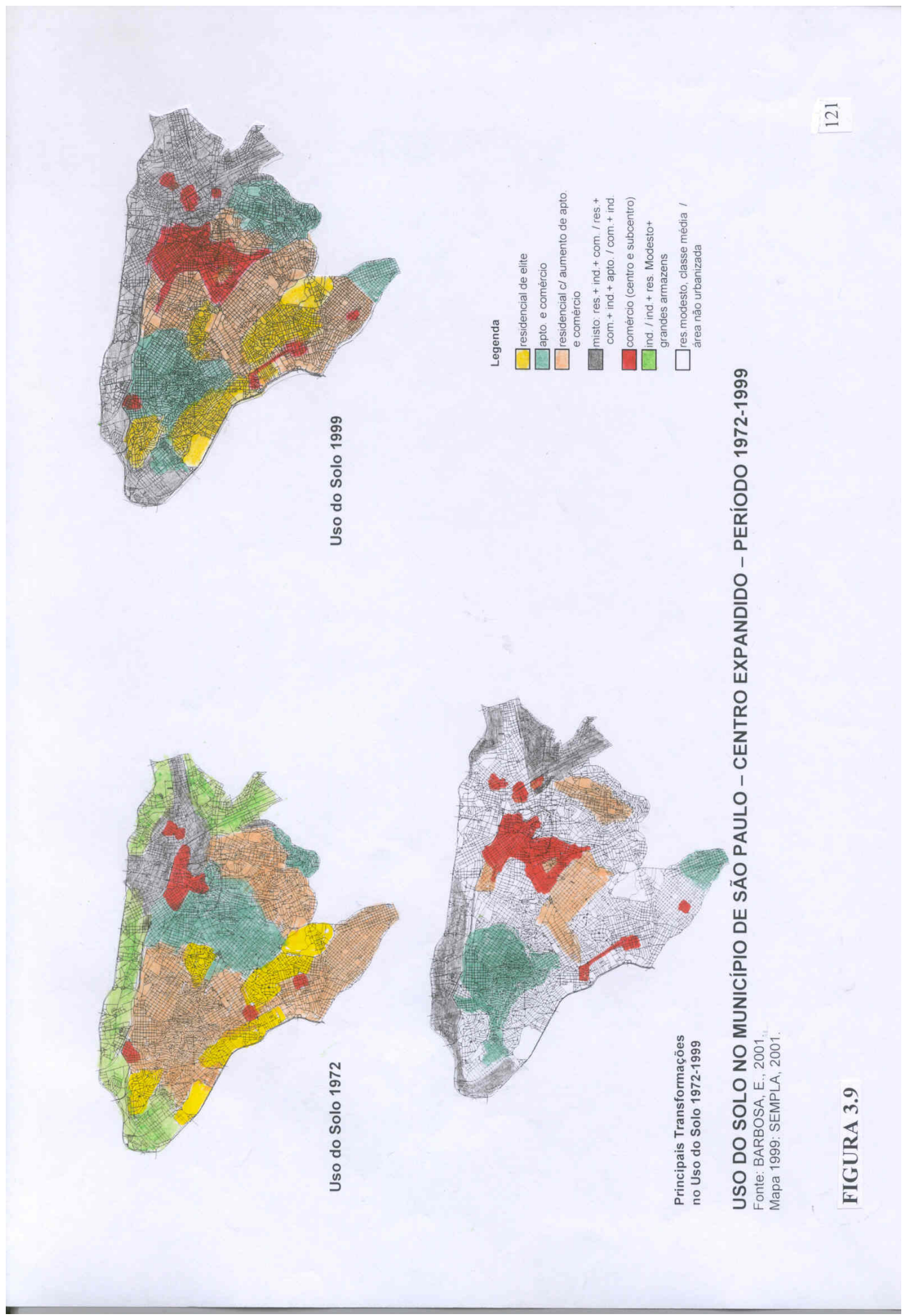

Figura 3.9. Uso do solo no centro expandido 1972-1999 (original em cópia colorida) 


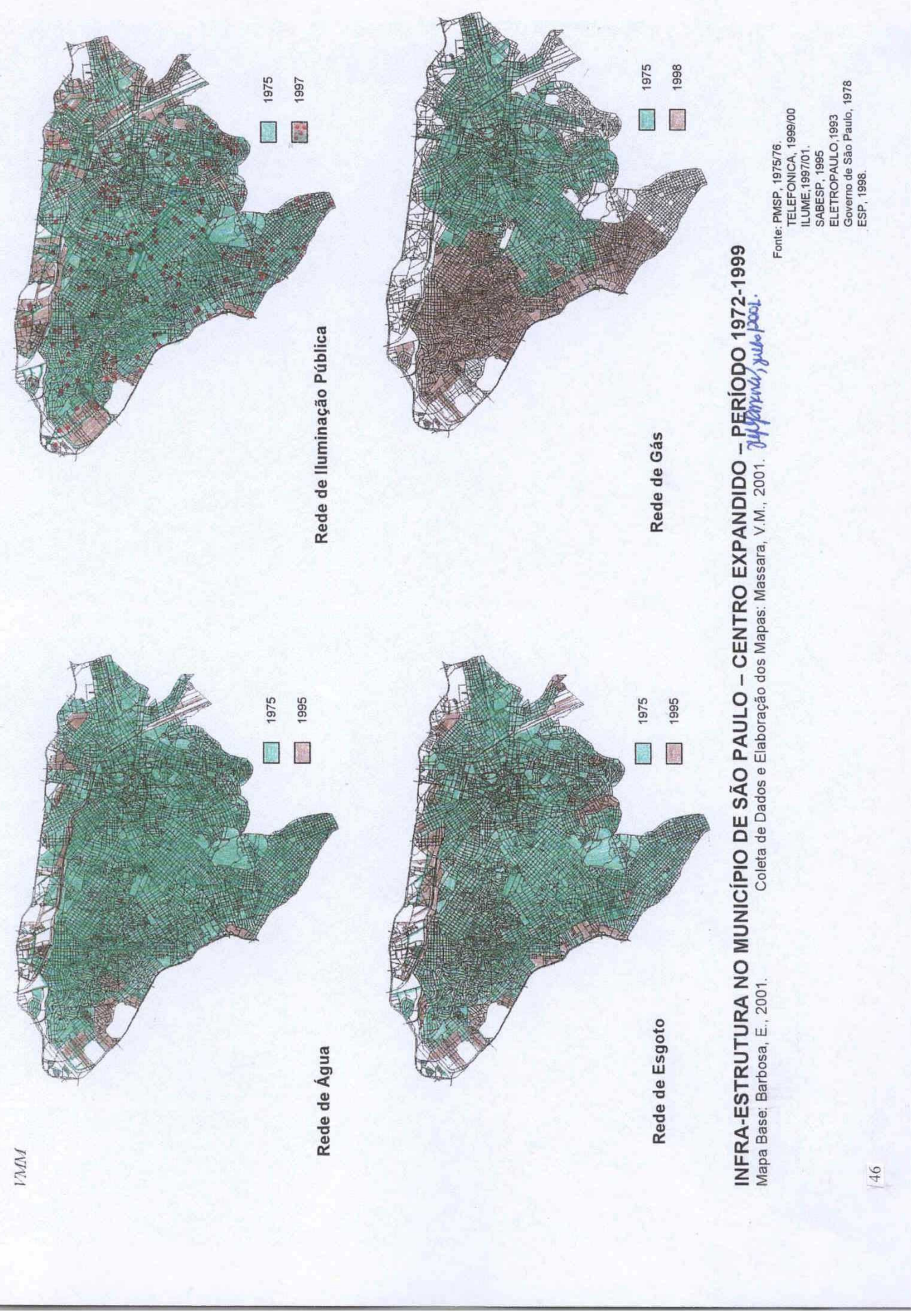

Figura 3.10. Infra-estrutura no centro expandido 1972-1999 (original em cópia colorida) 


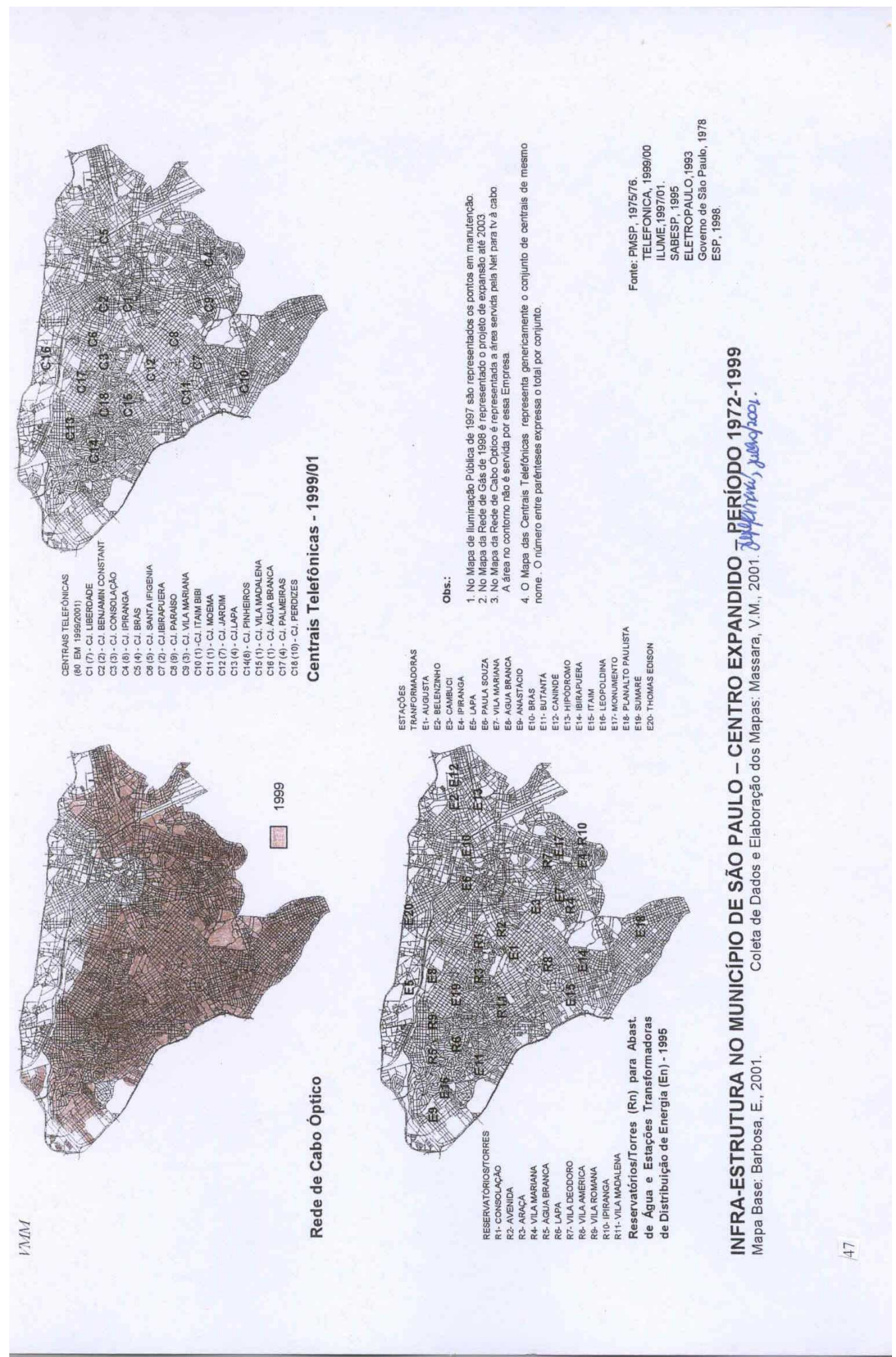

Figura 3.11.. Infra-estrutura no centro expandido 1972-1999 (original em cópia colorida) 


\subsubsection{Transformações no uso do solo no período 1890-1999}

No início do período, a cidade ainda passava pelo processo de loteamento das chácaras, com grandes vazios separando as áreas centrais de núcleos localizados a grandes distâncias como Santo Amaro, Pinheiros, Nossa Senhora do Ó, Ipiranga, Nossa Senhora da Penha, São Miguel Paulista, entre outros, fugindo das várzeas e seguindo a topografia, enfrentando problemas na transposição dos rios e com o suprimento de água.

A Estação da Luz e a Estação do Norte no Brás, próximo a Hospedaria dos Imigrantes, formou um pequeno centro de atividades e reduto do operariado. $\mathrm{Da}$ mesma forma a Lapa, Barra Funda e Água Branca a noroeste, prolongou a faixa de característica industrial e proletária, ligando Pari, Brás, Belenzinho e Mooca.

O sul e sudoeste, não possuíam a linha férrea e passaram a ser ocupados por residências. A subdivisão das chácaras de Santa Efigênia e Campos Elíseos concentrou os interesses da elite em ascensão, assim como parte da Praça da República. O avanço dessa elite através de Higienópolis até a Avenida Paulista prosseguiu a sudoeste e formou os "Jardins". A expansão seguinte é caracterizada pela formação de áreas de uso misto, concentrada no aumento de edifícios e comércio se estendendo a Perdizes, Bela Vista e Liberdade.

Com o processo de desindustrialização local, parte da área industrial do Pari e Brás e depois toda a extensão, começando da Vila Leopoldina, se torna de uso misto.

A região do centro antigo é aquela que mantem ao longo do século $\mathrm{XX}$ a característica de área comercial, embora modificando o tipo de comércio, cada vez mais voltada para a classe de menor poder aquisitivo, bem como os subcentros do Brás, Lapa e de Pinheiros, voltados ao nível de renda de sua população. O maior impacto nesse campo, foi a intensificação da área comercial por toda a região dos Campos Elíseos, Santa Cecília e Consolação até a Avenida Paulista, alcançando a região da Avenida Brigadeiro Faria Lima.

No âmbito residencial, a enorme verticalização tomou conta de vasta área desde Perdizes até Moema e a sudeste, na Liberdade, Aclimação e parte do Cambuci, sendo intercalada apenas com pontos ocupados pela elite e protegidos pela legislação 
nos Jardins América e Europa e no Ibirapuera. O Alto da Lapa e Alto de Pinheiros também se mantiveram como bairros para a classe de maior renda.

A influência das melhorias no sistema viário e nos meios de transporte, não está inclusa nesta pesquisa, mas não podemos deixar de mencioná-la como fator de desenvolvimento: a estrada de ferro na formação dos bairros populares e as importantes avenidas na concentração de edifícios residenciais e de prestação de serviços (vide BARBOSA, 2001).

\subsubsection{Infra-estrutura versus uso do solo}

A combinação de informações gráficas sobre a implantação das redes e transformações no uso do solo com o histórico de desenvolvimento dos bairros mostrou:

- a existência de infra-estrutura não pode ser considerada fator de atração de diferentes usos do solo. Podemos dizer, que com exceção da Avenida Paulista, pequena parte da Vila América ${ }^{79}$ e Alto da Lapa, todos empreendimentos da Companhia City, nenhum bairro foi iniciado pela pré-existência dos serviços;

- a afirmação anterior induz ao questionamento sobre a rapidez com a qual as redes são implantadas e sua relação com fatores construtivos, históricos, de distribuição de renda e de concentração demográfica, assim como a importância da localização e acessibilidade como determinantes para a atração de usos e conseqüente instalação de infra-estrutura ${ }^{80}$;

- indústrias de grande porte têm infra-estrutura própria, fato que pode justificar várias ruas da região da Barra Funda, Pari e Lapa de Baixo ainda não possuir rede de saneamento nos mapas "rua a rua" da SABESP de 1995 (figura 3.10);

- a implantação das redes segue uma distribuição concêntrica, partindo do centro antigo; em geral, áreas comerciais são as primeiras a possuírem todas as redes (provavelmente por este uso se desenvolver a partir do centro);

- a sequência padrão de implantação da infra-estrutura de primeira necessidade segue a ordem: energia elétrica, abastecimento de água e coleta de esgotos ${ }^{81}$;

- a concentração de renda possibilita usos do solo mais sofisticados e exige a implantação de infra-estrutura como cabo óptico e gás canalizado, em outras áreas considerada supérflua.

\footnotetext{
${ }^{79}$ Idem 76.

${ }^{80}$ A análise detalhada do peso de cada um dos fatores contribuintes para a implantação das redes não é objeto deste estudo.

${ }^{81}$ Segundo o Plano Urbanístico Básico, PMSP, 1968: "há uma defasagem aproximada de 15 anos, entre o atendimento do primeiro serviço (energia) e o segundo (rede de água)". Afirmação confirmada pela entrevista com a Superintendência Técnica da Eletropaulo em 2000.
} 

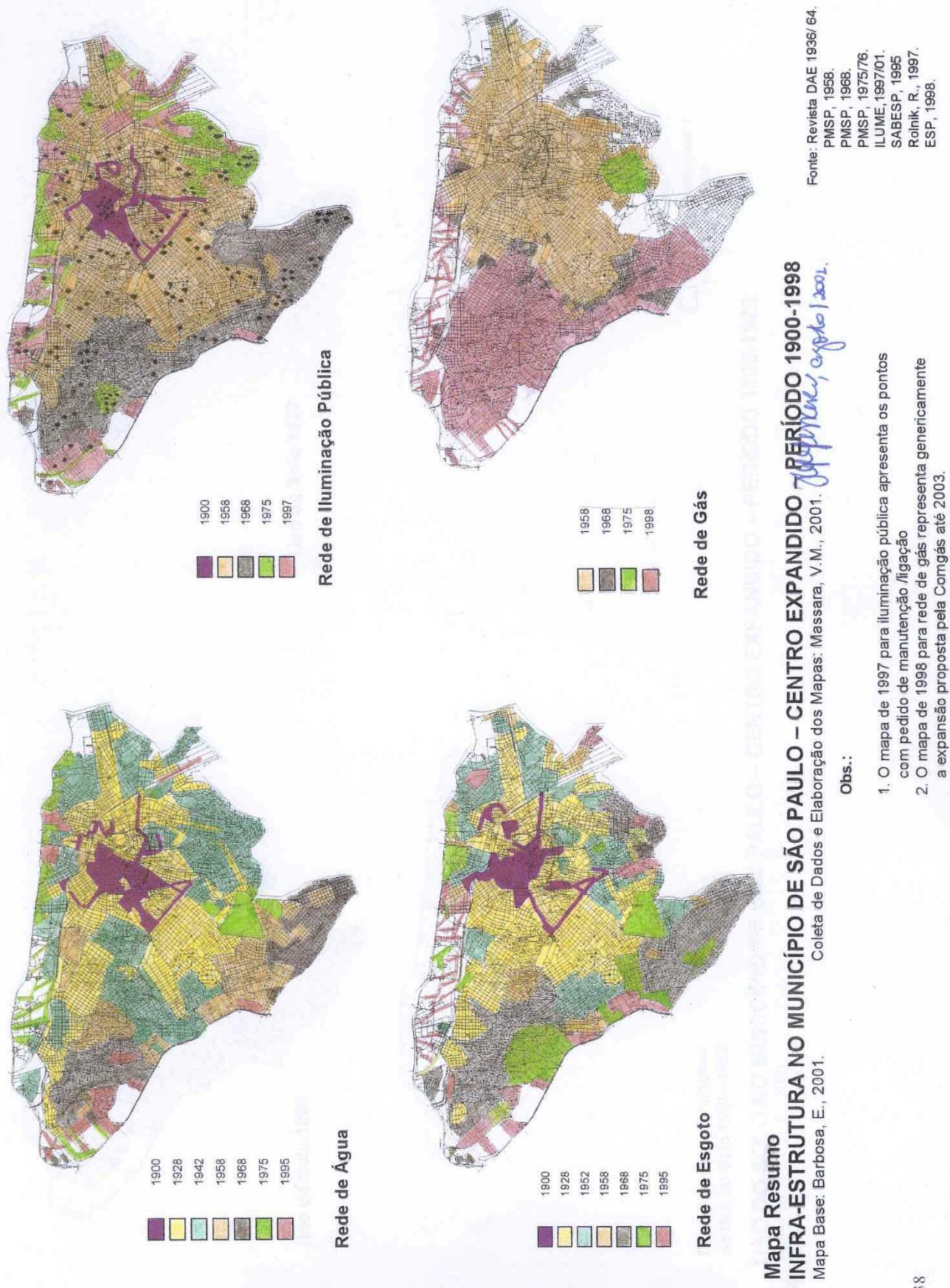

Figura 3.12. Resumo Infra-estrutura no centro expandido 1890-1999 (original em cópia colorida) 


\section{Capítulo 4. A implantação de infra-estrutura e as transformações no uso do} solo: a região de São Miguel Paulista no período 1968 - 1999 - 2001

\subsection{A escolha da Região de São Miguel Paulista}

$\mathrm{Na}$ intenção de confrontar o contraste na expansão das redes e a influência no uso do solo analisamos qual área da periferia poderia ser expressiva para elaborar essa comparação. Observamos que três setores da cidade apresentavam a mesma característica de distribuição territorial das redes: zonas leste, norte e sul.

Segundo pesquisa inicial sobre as três áreas, selecionamos a zona leste, visando não entrar em questões de grande complexidade como a análise da ocupação de regiões próximas aos mananciais como a reserva da Cantareira e a represa de Guarapiranga.

Confirmamos a escolha, ao analisarmos os mapas da expansão da mancha urbana e da densidade construída no período de 1930 a 1999, que apresentam baixa ocupação de grande parte das zonas sul e noroeste, evidenciando que a deficiência dos serviços nessas áreas pode estar ligada a densidade demográfica o que novamente tornaria necessária a inclusão de outras variáveis para verificação da relação entre variação da população e velocidade de implantação das redes, fugindo ao escopo deste trabalho.

Partindo da zona leste, determinamos dentro de seu perímetro a área da figura 4.1, de forma a excluir regiões da Penha a Ermelino Matarazzo (no sentido Leste) e Penha à Vila Prudente (sentido Sul), que mesmo fora do "centro", já usufruíam dos serviços, invalidando a proposta de estudar uma região com grande deficiência; da mesma forma, a região ao sul de Itaquera também foi excluída, por apresentar baixa taxa de ocupação e zonas de característica rural.

Assim, delimitamos como região de estudo o perímetro aproximado dos distritos de São Miguel Paulista, Jardim Helena, Vila Jacuí, Vila Curuçá e parte de Itaquera e Ermelino Matarazzo, incluindo importantes avenidas e centros de comércio e que possui a característica necessária para o estudo da implantação de infra-estrutura em $1975^{82}$ somente o centro de São Miguel usufruindo dos serviços e

${ }^{82} \mathrm{O}$ primeiro mapeamento localizado que apresenta pontos com existência de redes de abastecimento de água e coleta de esgotos é de 1975, sendo este o marco do período de estudo da infra-estrutura. A data exata do início de implantação dos serviços é estimada em relatórios da revista do Departamento de Água e Esgotos - D.A.E, como sendo entre os anos de 1972 e 1975. 
a região ao redor com total carência e após 20 anos, toda área atendida com poucos pontos deficientes, principalmente no tocante a rede de abastecimento de água e coleta de esgotos.

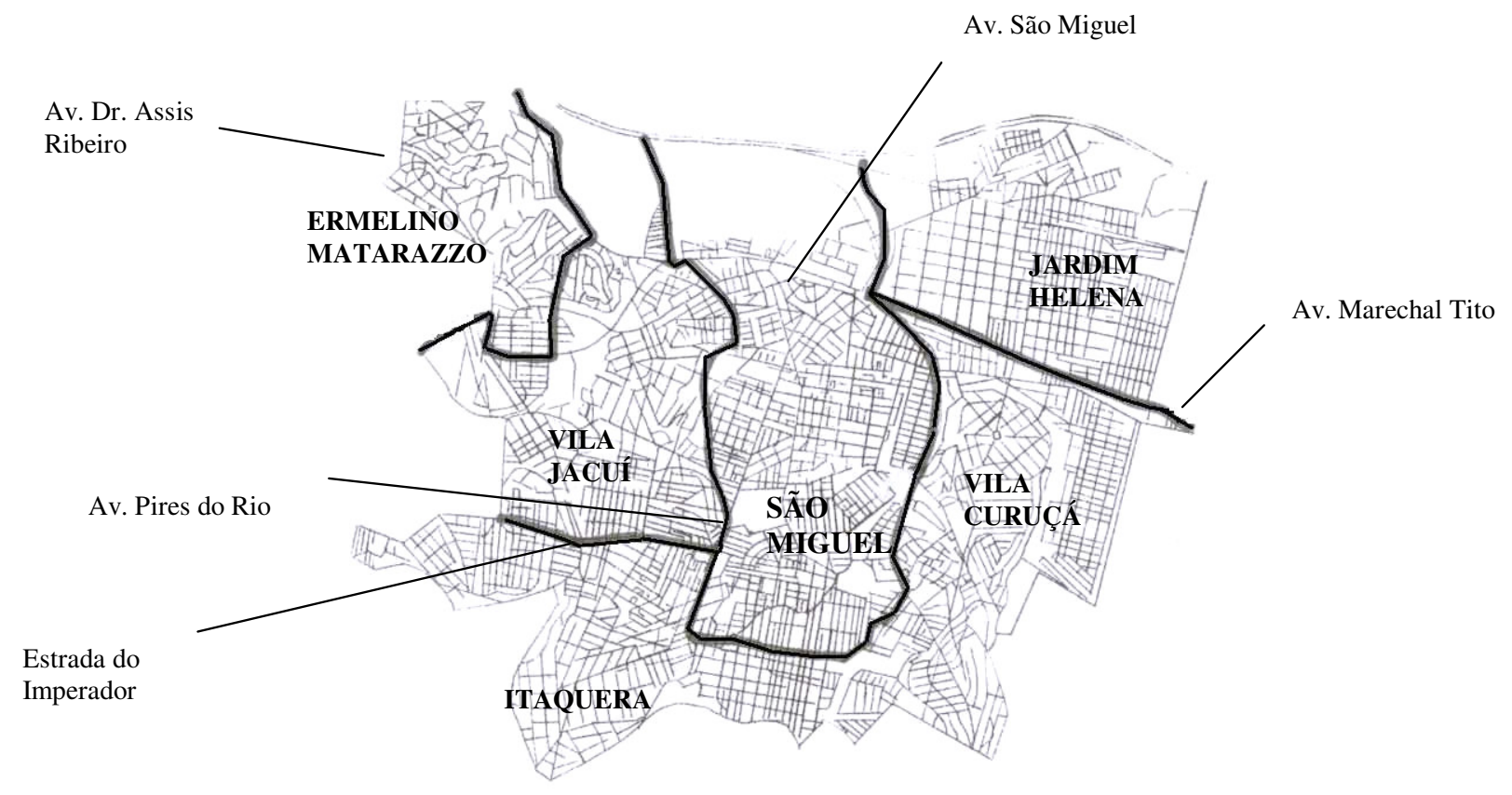

Figura 4.1. A região de São Miguel Paulista ${ }^{83}$.

Fonte: SEMPLA, 2001.

Nota: figura sem escala

${ }^{83}$ Será constante mencionarmos dados sobre a região através do nome de bairros e vilas. Desta forma utilizando uma estimativa do perímetro, relacionamos a seguir essa denominação a divisão oficial em distritos pela Lei de 1991:

Distrito São Miguel Paulista: Cidade Nova São Miguel, Vila Nair;

Distrito Jardim Helena: Parque Paulistano, Jardim São Martinho, Cidade Nitroperária (Nitroquímica);

Distrito Ermelino Matarazzo: Jardim Matarazzo, Parque Cruzeiro do Sul;

Distrito Vila Curuçá: Jardim dos Ipês;

Distrito Vila Jacuí: Jardim das Camélias, Jardim Santa Maria, Jardim da Casa Pintada;

Distrito Itaquera: Vila Progresso, Vila Verde, Parque Guarani. 
Outro ponto relevante para determinação do período de estudo, foi o peso da influência das redes em uma região periférica. Entre as sete redes estudadas, foram consideradas mais importantes para o desenvolvimento urbano: e a rede de energia elétrica, a rede de abastecimento de água, a rede de coleta de esgotos e a rede de iluminação pública.

A primeira delas foi descartada por acompanhar a expansão urbana independentemente da região (SEMPLA, 1983; ELETROPAULO, 2001).

Desta forma, foram utilizadas as três outras para efeito de visualização do processo de evolução da infra-estrutura na região e determinação do período de estudo.

Justificamos esse posicionamento considerando que a rede de gás canalizado ainda está pouco expandida e a utilização de botijões e aquecimento elétrico supre a necessidade até em bairros mais nobres. A rede de telefonia fixa é bastante cômoda e ainda existem áreas periféricas que tem baixa densidade de aparelhos, mas com o advento e enorme expansão da telefonia celular e dos orelhões que recebem chamadas, essa questão já não tem a mesma importância.

A rede de cabos ópticos, que tem a função de acelerar a transmissão de dados, imagem e voz em grandes distâncias, está em franca expansão no que tange a áreas de prestação de serviços e, no que se refere a lazer, até mesmo os distritos periféricos já contam com o serviço para utilização de tv's a cabo.

O período de 1975 a 1997 concentra três momentos distintos da distribuição dos serviços:

- $\quad$ na década de 70, a quase total ausência das redes;

- na década de 80 a expansão das redes de abastecimento de água e iluminação pública;

- na década de 90 a expansão da rede coleta de esgotos. O esquema a seguir, mostra a expansão das redes escolhidas como base para a análise ${ }^{84}$.

\footnotetext{
${ }^{84}$ A figura 4.7. mostra a distribuição territorial das redes no período 1975 - 1997 "rua a rua".
} 
Condição das Redes de Infra-Estrutura na Zona Leste - Período 1975-1997

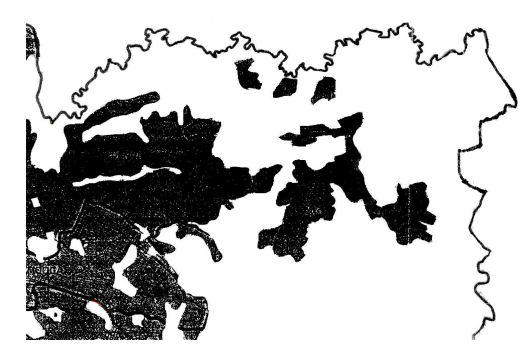

(a) 1975

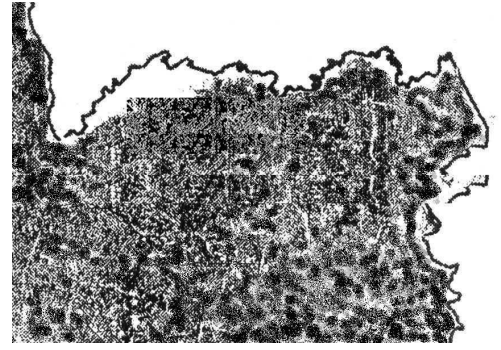

(b) 1995

Figura 4.2. Rede de abastecimento de água na Zona Leste Fonte: PMSP, 1975/76; SABESP, 1995.

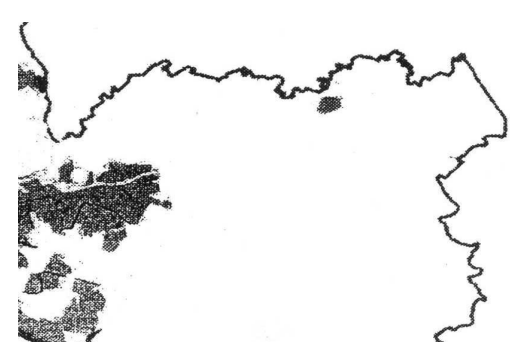

(a) 1975

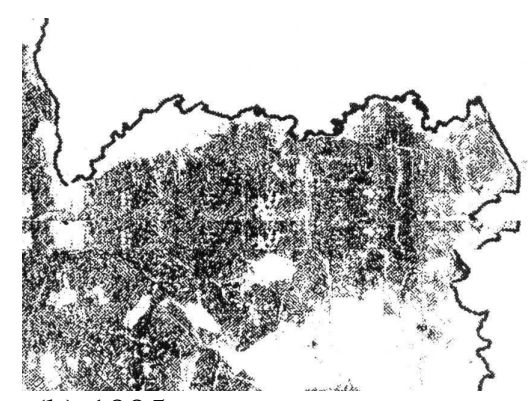

(b) 1995

Figura 4.3. Rede de coleta de esgotos na Zona Leste Fonte: PMSP, 1975/76; SABESP, 1995.

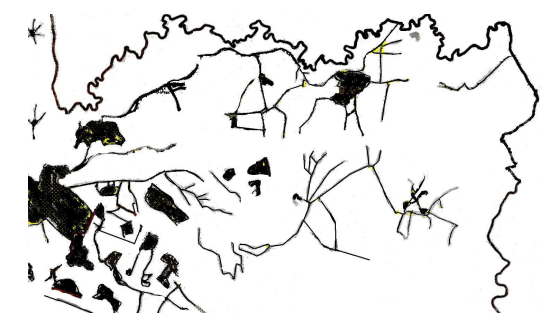

(a) 1975

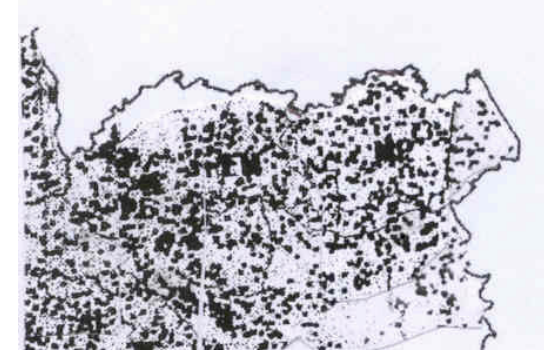

(b) 1997

Figura 4.4. Rede de Iluminação Pública ${ }^{85}$ na Zona Leste Fonte: PMSP, 1975/76; ILUME, 2001.

Nota: figura sem escala

\footnotetext{
${ }^{85}$ Notar que na figura 4.4 (a), está indicada apenas a rede e na (b), na área coberta pela rede, a deficiência de iluminação pública é expressa pelos pontos com pedidos de ligação ou manutenção (como troca de lâmpadas). Quanto maior a densidade de pontos, mais carente de iluminação é a região.
} 


\title{
4.2. A Região de São Miguel Paulista - características históricas
}

\author{
"a distância física é significativa para \\ as relações humanas quando pode ser \\ interpretada em termos de distância \\ social."
}

(HILMANN apud BOMTEMPI, 1970, p.173).

Durante o século XIX, o bairro passa por longa estagnação e não vai além de paupérrima comunidade apartada do centro urbano e sem meios próprios de desenvolvimento. Ainda nas últimas décadas desse século o Governo da Província e a Câmara de São Paulo praticamente nada sabiam de São Miguel a não ser comentários sobre sua situação de penúria.

Quando a Lei Provincial de 1880 confere a denominação de "Vila" a Conceição dos Guarulhos ${ }^{86}$, o território da Freguesia de Nossa Senhora da Penha de França e dentro dele, o bairro de São Miguel passam a fazer parte da nova Vila. Depois da Proclamação da República, o Governo do Estado fica isento de despesas ao criar distritos de "sentido meramente administrativo". Assim, por pressões de sua população, levando em conta o caráter histórico da região na formação da cidade de São Paulo acaba por convencer o então Governador Américo Brasiliense que, em 1891 incorpora São Miguel ao município e o eleva a categoria de Distrito.

Nos primeiros anos do século XX a área é uma pequena vila ao redor de centenária capela até as margens do Rio Tietê. Com características rurais e junto as regiões de Itaquera e Lageado (atual Guaianazes) vai recebendo imigrantes principalmente portugueses e japoneses - que fazem do cultivo de hortaliças e legumes importante fonte de renda.

No período de 1901 a 1914 o número de construções aumenta consideravelmente e outras fontes de renda passam a ser representativas, como a extração de madeira e de barro. A primeira usada na construção civil e no comércio

\footnotetext{
${ }^{86}$ No período anterior, Guarulhos, Penha e São Miguel faziam parte do Município de São Paulo.
} 
de lenha e carvão e a segunda nas olarias, usando como meio de transporte de sua produção, o Rio Tietê.

Os primeiros loteamentos - abertos nas áreas inter-córregos - raramente tinham comunicação entre si; "eram implantados de forma a terem pelo menos, um eixo estruturador: uma via de penetração locada no divisor de águas... as ruas que desciam desse eixo em direção às margens dos riachos se interrompiam quando atingiam as terras mais baixas" (PMSP; SEMPLA, 1986). Um exemplo é a Vila Aimoré criada em 1925 e embora sem grande êxito, um marco no impulso da primeira expansão demográfica.

A região é marcada pelo isolamento criado pela distância ao centro da cidade e pela dificuldade nos meios de transporte. No início da década de 30, é criada a linha de ônibus São Miguel-Penha e a Estrada de Ferro Central do Brasil abre uma variante no seu tronco principal, inaugurando a Estação São Miguel.

A partir de 1935, são instaladas indústrias de grande porte como a Companhia Nitro-Química Brasileira, e logo após, as Indústrias Matarazzo, que foram as responsáveis por grande expansão populacional e pela criação das vilas operárias instaladas pelas próprias indústrias, originando um processo de divisão da propriedade imobiliária, fragmentada em milhares de pequenos lotes vendidos em prestações a longo prazo e "onde se erguem modestas casas sempre por terminar... a maior parte das construções não vai além de quarto e cozinha... no pequeno quintal, a instalação sanitária e a fossa, quase ao lado do poço de água” (BOMTEMPI, 1970, p.112). Já em 1948, São Miguel começava a se expandir em direção a cidade.

Embora com grande perspectiva, a expansão industrial ao longo da variante norte não atingiu o sucesso esperado. O processo industrial nos anos 50, tem como base na localização de novas indústrias a Rodovia e com isso as regiões da Presidente Dutra e Via Anchieta se tornam importantes pólos de atração e a São Miguel cabe a caracterização de bairro-dormitório, para assentamento de população de baixa renda devido a disponibilidade de transporte coletivo barato (ferrovia).

A expansão ocorre com a formação de bairros gerados por loteamentos obtidos pela simples divisão do solo sem planejamento e apoio das leis. A maioria deles, desconectados entre si, tendo a Estrada SP-Rio como único elemento da estrutura urbana a unir as diversas áreas formadas. 
Na década de 1960, existem sérios problemas com as vias de acesso: o velho caminho que levava a Penha, se tornou obsoleto. Os problemas habitacionais unidos a total carência por saneamento básico e iluminação pública fazem de São Miguel: “um bairro em têrmos provisórios" (BOMTEMPI, 1970, p.62) processo de melhorias ocorre a partir da metade da década de 70, quando São Miguel passa a ser considerado um importante subcentro de São Paulo ${ }^{87}$.

\subsection{Características gerais da população e ocupação}

\subsubsection{População ${ }^{88}$}

O grande incremento populacional teve início a partir da década de 60; as décadas de 80 e 90 marcam os períodos de maior velocidade de crescimento. Os dados a seguir expressam o aumento da população em número de habitantes.

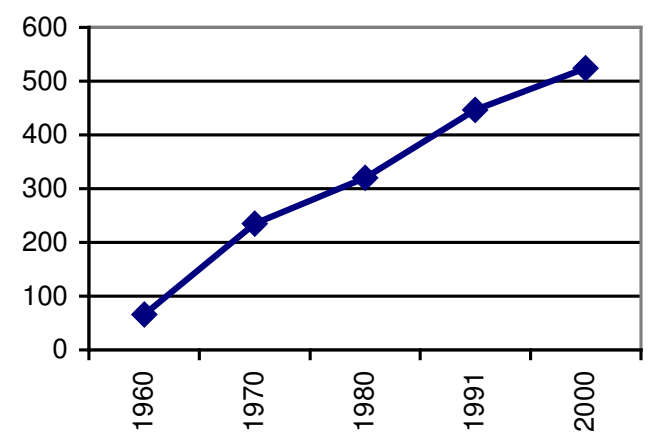

Gráfico 4.1. Evolução da população na região de São Miguel Paulista (em mil hab)

\begin{tabular}{|r|r|}
\hline Ano & População \\
\hline 1960 & 66.000 \\
1970 & 235.000 \\
1980 & 320.000 \\
1991 & 446.000 \\
2000 & 524.000 \\
\hline
\end{tabular}

Tabela 4.1. Evolução da população na região de São Miguel Paulista (em mil hab) Fonte: PMSP, 1975 ; EMPLASA, 1985 ; Rolnik, 1991 ; IBGE, 2000; Sempla, 2001.

${ }^{87}$ Observação retirada dos mapas apresentados por Villaça, F., na tese de doutorado: Estruturação da Metrópole Sul Brasileira, 1978.

88 Lembramos que em 70 e meados de 80, os Distritos de Jardim Helena, Vila Jacuí e Vila Curuçá integravam a área do Distrito São Miguel Paulista. 


\section{$\underline{\text { Renda Mensal }}$}

Segundo a SEMPLA (2000, vol.3), a condição socioeconômica da região é muito baixa, o distrito de São Miguel Paulista é o que apresentou maior evolução da renda familiar na última década.

Tabela 4.1. Evolução da renda mensal na região de São Miguel Paulista

\begin{tabular}{|l|l|l|l|}
\cline { 2 - 4 } \multicolumn{1}{c|}{} & até 2 SM & de 2 a 5SM & $\begin{array}{l}\text { superior a 5 } \\
\text { SM }\end{array}$ \\
\hline São Miguel & década 70 & década 80 & década 90 \\
Jardim Helen & década 70 & década 90 & \\
Vila Jacuí & década 70 & década 90 & \\
vila Curuçá & década 70 & década 90 & \\
\hline
\end{tabular}

\subsubsection{Ocupação}

Do ponto de vista da densidade demográfica, notamos que embora o crescimento populacional tenha sido expressivo não refletiu em aumento da densidade demográfica, já que a área demorou para ser totalmente ocupada.

Tabela 4.2. Faixas de densidade demográfica segundo os distritos ${ }^{89}$

\begin{tabular}{|l|l|l|l|}
\cline { 2 - 4 } \multicolumn{1}{c|}{} & até 80 hab/HA & $\begin{array}{l}\text { até } 150 \\
\text { hab/HA }\end{array}$ & $\begin{array}{l}\text { de 150 a 250 } \\
\text { hab/HA }\end{array}$ \\
\hline $\begin{array}{l}\text { São Miguel } \\
\text { Jardim Helena } \\
\text { Vila Jacuí } \\
\text { vila Curuçá }\end{array}$ & $\begin{array}{l}\text { década 70 } \\
\text { década 70 }\end{array}$ & $\begin{array}{l}\text { década 80/atual } \\
\text { década 80/atual }\end{array}$ \\
década 70 & & \\
\hline
\end{tabular}

Os dados levam em conta a densidade na maior área; ou seja, por exemplo, existem locais do Jd. Helena que ainda estão na faixa de $150 \mathrm{hab} / \mathrm{HA}$

Embora a porcentagem de terrenos vagos tenha diminuído significativamente a predominância de construções térreas e de 2 pavimentos é fator que se conserva ao longo dos anos.

A tabela a seguir expressa o crescimento de construções residenciais, evidenciando que somente no distrito de São Miguel houve transformação expressiva na possibilidade de ampliar a área das construções.

${ }^{89}$ Idem 88. 
Tabela 4.3. Quota média de área construída residencial por habitante

\begin{tabular}{|c|c|c|c|}
\hline & até $10 \mathrm{~m} 2 / \mathrm{hab}$ & até $20 \mathrm{~m} 2 / \mathrm{hab}$ & até $25 \mathrm{~m} 2 /$ hab \\
\hline $\begin{array}{l}\text { São Miguel } \\
\text { Jardim Helena } \\
\text { Vila Jacuí } \\
\text { vila Curuçá }\end{array}$ & $\begin{array}{l}\text { década 70/atual } \\
\text { década 70/atual } \\
\text { década 70/atual }\end{array}$ & década 70/80 & década 90 \\
\hline
\end{tabular}

Fonte: PMSP, 1975 / EMPLASA, 1985 / Rolnik, R. 1991 /Sempla, 2001.

Consideramos que estes aspectos sejam oriundos do processo de urbanização da cidade como um todo e da região em especial. A distância ao Centro estabelecido, agravada pela dificuldade de locomoção por problemas no sistema viário e nos meios de transporte, trouxe a população de menor renda e como conseqüência direta o desinteresse público e privado em incrementar os usos do solo, com melhores padrões de construção, criação de centros empregatícios, universidades etc., e simultaneamente interferiu na implantação de infra-estrutura, voltada por muito tempo somente ao centro de São Miguel.

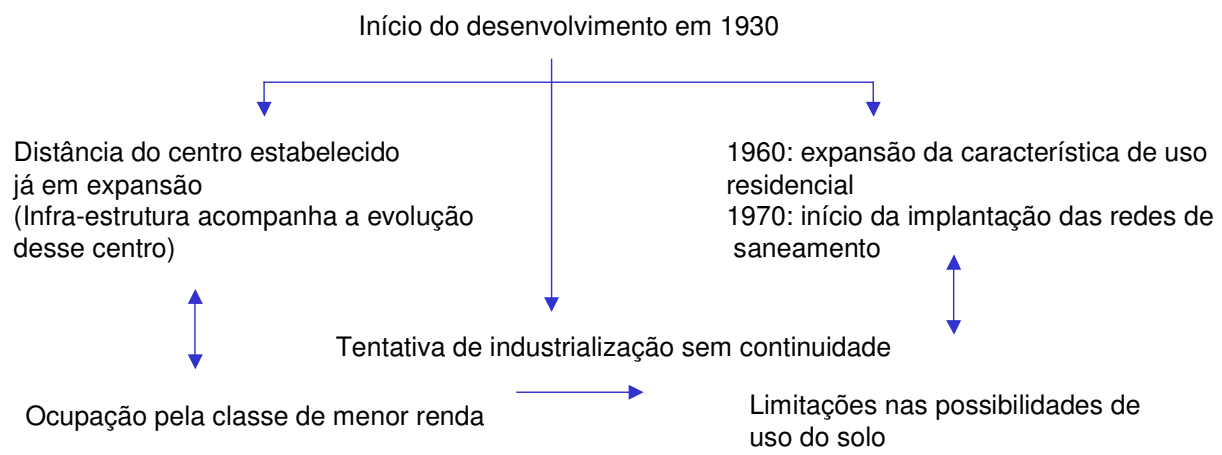

Figura 4.5. Causas e conseqüências das limitações na região

Elaboração: Massara, V.M., 2001. 


\subsection{Características gerais da infra-estrutura na região}

Alguns aspectos gerais da condição das redes de saneamento básico e iluminação pública, bem como características do consumo de energia em função do uso do solo são apresentadas aqui. Devido a mudanças na delimitação dos distritos durante o período de 1970/95 a maioria dos gráficos não pode ser combinada e tem apenas o intuito de fornecer uma visão geral da precariedade e do tardio avanço dos serviços nessa área, principalmente no tocante a coleta de esgoto (implantação a partir do final da década de 80) e iluminação pública (grande expansão no início da mesma década).

\subsubsection{Coleta de esgotos}

Porcentagem de atendimento no serviço de coleta de esgotos na região de São

\section{Miguel Paulista}

Gráfico 4.2. Em 1970

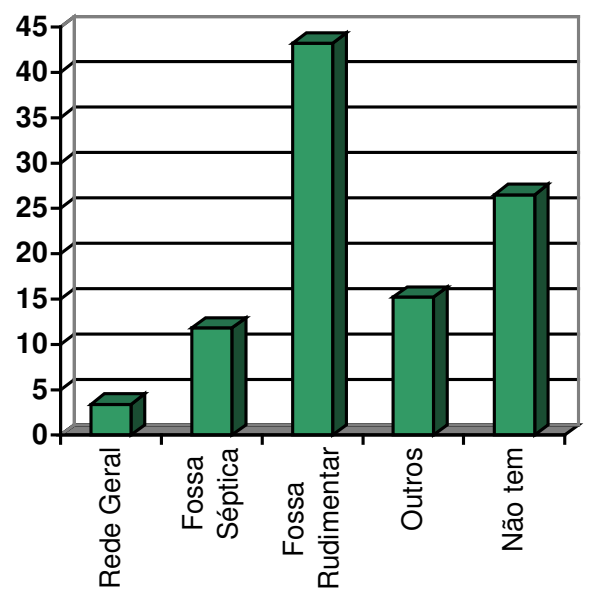

Gráfico 4.3. Em $1991^{90}$

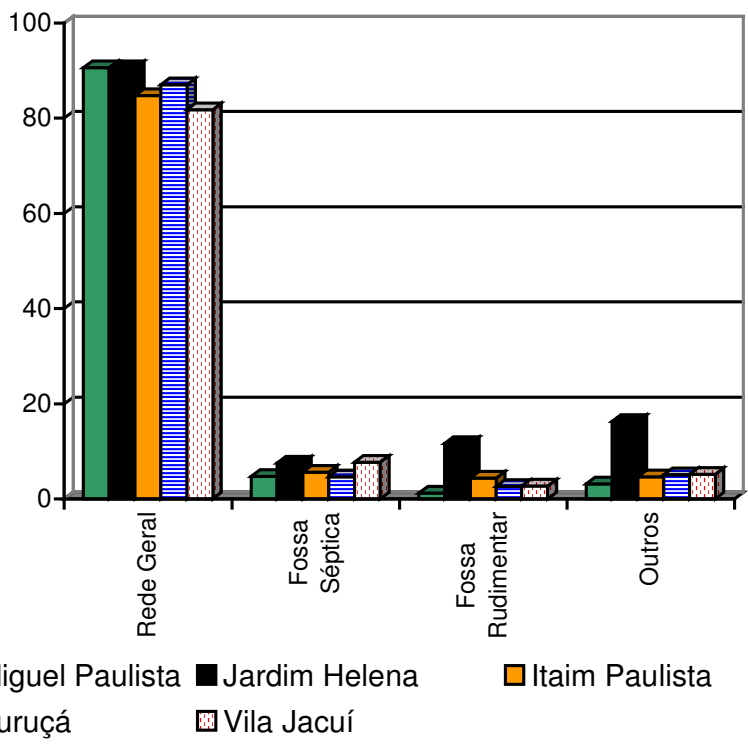

Fonte: EMPLASA, Sumário de Dados da Grande São Paulo, 1977/1995.

${ }^{90}$ Considerando a criação dos distritos Jardim Helena, Itaim Paulista, Vila Curuçá e Vila Jacuí a partir do desmembramento do Distrito de São Miguel. 
Tabela 4.4. Condições sanitárias $^{91}$ no período 1970/1 - Região de São Miguel Paulista.

\begin{tabular}{|c|c|c|c|c|c|}
\hline \multirow[b]{2}{*}{ Distritos } & \multicolumn{5}{|c|}{ Porcentagem de uso por tipo de escoadouro de esgoto } \\
\hline & rede geral & \begin{tabular}{|l|} 
fossa \\
séptica
\end{tabular} & $\begin{array}{l}\text { fossa } \\
\text { rudimentar }\end{array}$ & outros & não tem \\
\hline \multicolumn{6}{|c|}{1970} \\
\hline São Miguel Paulista & 3,4 & 11,8 & 43,2 & 15,2 & 26,4 \\
\hline \multicolumn{6}{|c|}{1991} \\
\hline São Miguel Paulista & 90,6 & 4,7 & 1,2 & 3,1 & $\overline{0,4}$ \\
\hline Jardim Helena & 83,6 & 7,6 & 1,7 & 6,1 & 1,0 \\
\hline Itaim Paulista & 84,8 & 5,6 & 4,4 & 4,6 & 0,6 \\
\hline Vila Curuçá & 87,1 & 4,6 & 2,6 & 5,1 & 0,6 \\
\hline Vila Jacuí & 81,8 & 7,7 & 4,7 & 5,2 & 0,6 \\
\hline
\end{tabular}

Até que o arruamento receba as redes de água e esgotos, os moradores sevemse de poços e fossas. A qualidade da água é em geral ameaçada pela infiltração das fossas, situação agravada em lotes periféricos, sem projeto aprovado e de dimensões mínimas, impossibilitando a construção com uma distância que impeça o contato entre ambos.

Assim, na região periférica é imprescindível a implantação das redes de saneamento básico, o que se torna complicado quando visto pelo enfoque da expansão desordenada e do grande número de loteamentos clandestinos nessas áreas.

\subsubsection{Abastecimento de água}

A presença da rede nem sempre pode ser entendida como pleno funcionamento. O problema atual da região quanto a utilização desse serviço, também consiste, na grande expansão de lotes que implica na variação do índice de regularidade no abastecimento. Em 1990, somente a região do centro de São Miguel em direção a Ermelino Matarazzo contava com índice superior a 80\%, o restante da área estava no intervalo entre 67 e $80 \%$ de constância do serviço, indicando grande incidência de rodízios na região. Dados da SEMPLA de 1999, mostram toda a região com regularidade de atendimento entre 90 a 99\%, com exceção da divisa entre os distritos Jardim Helena e Itaim Paulista que aparece no intervalo de 60 a 79\%, apresentando relativa evolução na eficiência do sistema.

\footnotetext{
${ }^{91}$ Outros: incluem por exemplo, a utilização de valas.
} 
Porcentagem de atendimento no serviço de abastecimento de água na região de São Miguel Paulista

Gráfico 4.4. $1970 / 91$

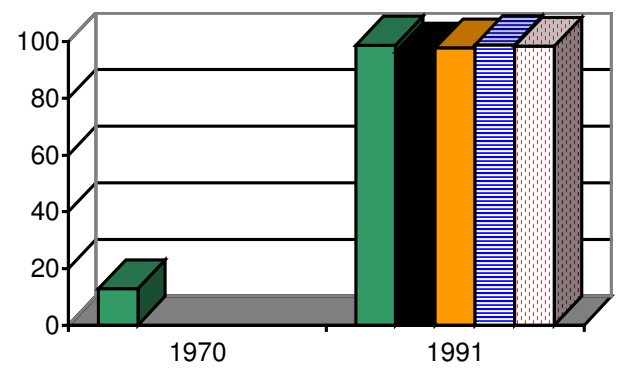

Tabela 4.5. 1970/91

\begin{tabular}{|c|c|c|c|c|}
\hline \multirow{4}{*}{$\begin{array}{l}\text { 口 São Miguel Paulista } \\
\text { Jardim Helena }\end{array}$} & \multirow[b]{2}{*}{ Distritos } & \multicolumn{3}{|c|}{ Porcentagem por tipo de abastecimento } \\
\hline & & rede geral & $\begin{array}{ll}\text { poço ou } \\
\text { nascente }\end{array}$ & outra forma \\
\hline & \multicolumn{4}{|c|}{1970} \\
\hline & São Miguel Paulista & 12,8 & & 7,2 \\
\hline \multirow{6}{*}{$\begin{array}{l}\text { 口 Itaim Paulista } \\
\text { 目 Vila Curuçá } \\
\text { ⿴囗V Vila Jacuí }\end{array}$} & \multicolumn{4}{|c|}{1991} \\
\hline & \begin{tabular}{|l} 
São Miguel Paulista \\
\end{tabular} & 98,8 & 0,11 & 1,09 \\
\hline & Jardim Helena & 96,3 & 0,95 & 2,75 \\
\hline & Itaim Paulista & 97,8 & 0,35 & 1,85 \\
\hline & Vila Curuçá & 98,9 & 0,49 & 0,61 \\
\hline & Vila Jacuí & 98,4 & 0,35 & 1,25 \\
\hline
\end{tabular}

Fonte: EMPLASA, Sumário de Dados da Grande São Paulo, 1977/1995.

\subsubsection{Iluminação Pública}

Na década de 80 houve grande expansão do serviço através de um sistema denominado de iluminação econômica, que segundo a $\operatorname{SEMPLA}^{92}$ (1986), reduziu em até $50 \%$ os custos de implantação em relação aos métodos tradicionais. Esse sistema foi baseado na utilização de lâmpadas de menor potência e no uso de postes já existentes para distribuição de energia domiciliar. Atualmente, dados do ILUME de 1999, consideram o mapeamento de pontos com pedido de manutenção ou de ligação. Esta forma de apresentação não traduz uma porcentagem de atendimento exata. Estima-se que, considerando a região como um todo, os pedidos referentes a instalação, estão entre 4 e $10 \% .^{93}$

Gráfico 4.5. Porcentagem de vias com iluminação pública (em relação ao total de vias) da região de São Miguel Paulista.

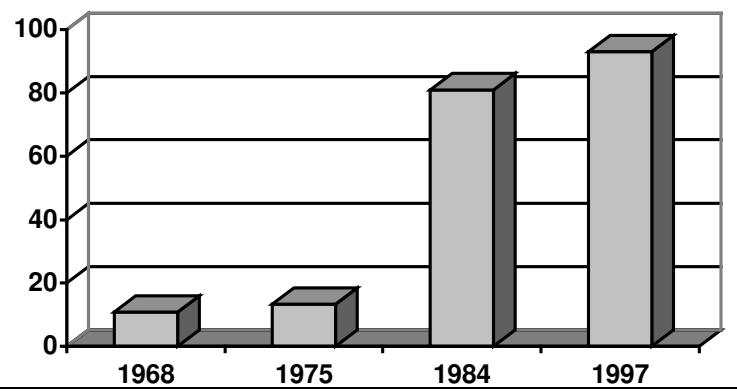

92 Esta observação foi retirada do Plano Diretor do Município 1985 - 2000, 1986.

${ }^{93}$ Segundo afirmação da Divisão de Ampliação de Serviços em entrevista de julho, 2000. 
Tabela 4.6. Resumo das Con4dições de Iluminação Pública no período 1970/1991 Região de São Miguel Paulista.

\begin{tabular}{|r|c|}
\cline { 2 - 2 } \multicolumn{1}{c|}{} & \% de Vias iluminadas \\
\hline 1970 & 10,8 \\
\hline 1975 & 13,3 \\
\hline 1984 & 75,6 \\
\hline 1997 & $90 \mathrm{a} 96$ \\
\hline
\end{tabular}

Fonte: PMSP, 1968; PMSP, 1975/76; SEMPLA, 1985, ILUME, 2001.

\subsubsection{Consumo de energia elétrica ${ }^{94}$ por tipo de uso}

Gráfico 4.7. Porcentagem de ligações a rede geral de energia elétrica- São Miguel Paulista 1970

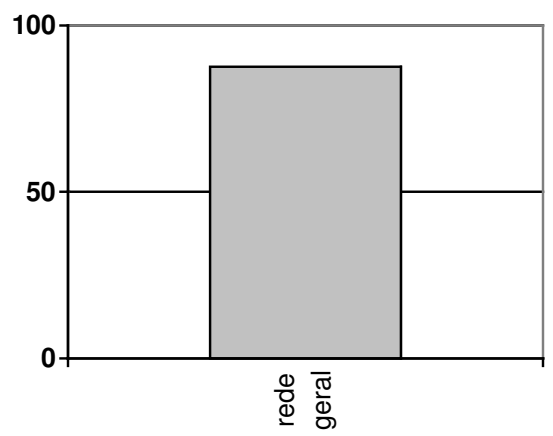

Gráfico 4.8. Porcentagem de consumo de energia elétrica / tipo de uso - São Miguel Paulista 1985/91

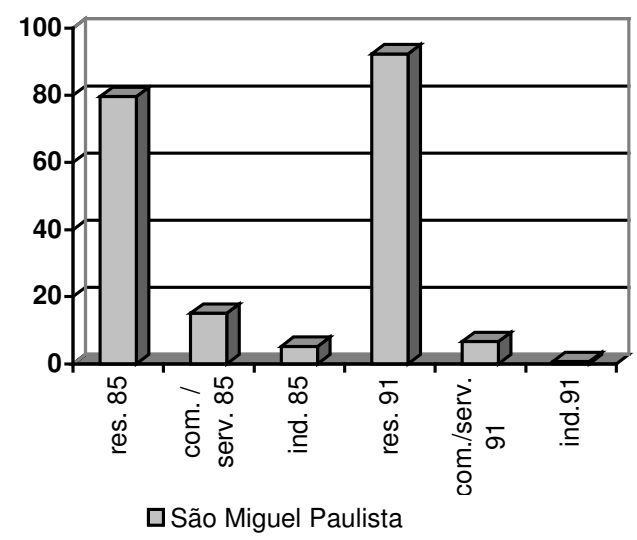

Fonte: IBGE, Censo Predial 1970; EMPLASA, 1986; 1994.

Tabela 4.7. Consumo de energia elétrica 1970/91 - Região de São Miguel Paulista

\begin{tabular}{|l|r|r|r|r|}
\hline \multirow{2}{*}{ Distritos } & \multicolumn{4}{|c|}{ Porcentagem por tipo de uso } \\
\cline { 2 - 5 } & residencial & comercial & industrial & outros \\
\hline \multicolumn{5}{|c|}{1970} \\
\hline São Miguel Paulista & $87,2^{*}$ & \multicolumn{3}{|c|}{12,8} \\
\hline \multicolumn{6}{|c|}{1991} \\
\hline São Miguel Paulista & 92,3 & 6,6 & 0,6 & 0,5 \\
Itaim Paulista & 94,4 & 4,8 & 0,4 & 0,4 \\
\hline
\end{tabular}

* ver a nota de rodapé

94 A Eletropaulo não considera separadamente os distritos de Jardim Helena, Vila Curuçá e Vila Jacuí. 
Através do Gráfico 4.8., nota-se como os usos comercial/serviços e industrial diminuíram em relação ao uso residencial, reforçando a característica de "bairrodormitório" dessa região.

\subsubsection{Gás}

A rede de gás é inexistente em toda a região.

\subsubsection{Telefonia}

O índice de atendimento da região é inexpressivo até a metade dos anos 90. Os primeiros relatórios localizados sobre a densidade de aparelhos e a instalação de centrais telefônicas datam de 1940 (LEÃO, 1940) e mencionam na Zona Leste apenas a Central do Tatuapé. Já em 1958 (PMSP, 1961), mapeamento mostra o avanço da rede através da Mooca em direção a Penha. Nas décadas seguintes a situação se mantem praticamente estagnada.

Em 1988 (ROLNIK et al., 1991), a densidade de aparelhos a cada 100 habitantes está na faixa de 2 a 5 terminais, correspondendo ao menor índice de atendimento do Município, somente semelhante a zona sul e aos atuais distritos de Anhanguera e Perus. Uma década depois (1999) os dados da TELEFONICA (2001) apresentam um aumento considerável desse valor, estimando a densidade das centrais São Miguel, Jardim Helena e Itaim Paulista em 12,3 aparelhos a cada grupo de 100 habitantes, valor ainda pequeno se comparado a regiões centrais, mas expressivo quando em relação ao histórico desse serviço na área.

\subsubsection{Cabo óptico}

Nessa região não existe um sistema de anel óptico como na área central, com a função de otimizar o uso de computadores. Informações de 1999 mostram que a rede instalada para tv's a cabo abrange apenas o Centro de São Miguel. 


\subsection{Uso do Solo e Infra-Estrutura em São Miguel Paulista}

\subsubsection{Período 1968 - 1975}

Partindo do primeiro mapeamento ${ }^{95}$ localizado sobre uso do solo em São Miguel, iniciamos o período de estudo em 1968 e a partir desse ano, estudamos o incremento das redes de infra-estrutura na região.

O relatório mencionado, permite verificar que apenas a área atualmente ocupada pelo distrito de São Miguel, pequena parte das Vilas Jacuí e Curuçá com ligação em estreito trecho do atual Jardim Helena eram edificadas. O esquema da figura 4.6., mostra de forma resumida o uso e ocupação do solo nessa época. A maior concentração está em residências unifamiliares (horizontais) de baixo padrão semi-isoladas, ocupando aproximadamente $52 \%$ da região. $\mathrm{O}$ segundo item preponderante é o de terrenos vagos (não loteados), totalizando $40 \%$.

O uso misto é expresso como a combinação entre residências e comércio (estimada em 3\%), localizado em áreas contíguas ao Centro de São Miguel e também pela combinação entre uso comercial e de prestação de serviços expressivo no centro e em trechos da atual Avenida Marechal Tito, próximos a Vila Curuçá (estimado em 5\%). Quanto ao uso industrial, apenas as áreas da Nitroquímica e das Indústrias Reunidas Matarazzo ${ }^{96}$ são relevantes, o que será constante nos 30 anos de abrangência desta pesquisa. Não existem redes de infra-estrutura.

\subsubsection{Período 1975 - 1985}

Entre os anos de 1968 a 1972, não houve avanço na implantação das redes; os primeiros núcleos servidos por saneamento e iluminação pública surgem no período 1972 - 1975. Como mostra o esquema da figura 4.7., a rede de água aparece em pequenas áreas; a predominância ocorre no centro de São Miguel e nas imediações do cemitério da Saudade cobrindo parte dos bairros de Santa Maria, Jardim da Casa Pintada, Cidade Nova São Miguel e Lageado; pequena parte da Vila Jacuí e da Cidade São Miguel também é abastecida assim como o Parque Cruzeiro

\footnotetext{
${ }^{95}$ Este mapa foi retirado do Plano Urbanístico Básico de 1968. Mapas anteriores, não fazem menção a ocupação do extremo leste , limitando a apresentação ao distrito da Penha, ou são de difícil interpretação como os do Departamento de Urbanismo - "Planejamento" do período 1957-1961.

${ }^{96}$ Esta última, encerrou suas atividades na década de 80, embora a área permaneça com uso industrial.
} 
do Sul (a oeste do centro) que é praticamente todo servido. A rede de coleta de esgotos é bastante precária: um pequeno núcleo é beneficiado junto a estação ferroviária de São Miguel, correspondendo aproximadamente a algumas quadras da Vila Nair. Abaixo da estrada de ferro, a rede existe no perímetro do Centro de São Miguel; no restante da área de estudo o serviço é inexistente.

As áreas iluminadas com rede pública são reduzidas e localizam-se junto às estações ferroviárias e em vias urbanas principais como a Estrada de São Miguel (atual Avenida São Miguel), Estrada do Lageado (atual Avenida Nordestina), Estrada São Paulo (atual Avenida Marechal Tito) e em outras vias de acesso aos bairros; a predominância ocorre na área que coincide com aquela servida por rede de esgoto e mais algumas quadras na direção Leste em relação ao Centro de São Miguel chegando nas proximidades da Cidade Nitroperária (região abaixo do Parque Paulistano).

\subsubsection{Diagnóstico 1985}

Segundo mostra a figura 4.9., a área é uma "cidade dormitório", caracterizada pelo baixo padrão das construções embora na década de 80, uma mancha de padrão médio tenha se estabelecido entre o centro de São Miguel e Ermelino Matarazzo.

Este centro mantem a forma triangular, concentrado no entorno da estação ferroviária, agrupando comércio, serviços e importantes equipamentos urbanos ${ }^{97} \mathrm{e}$ se expandindo ao longo das Avenidas Assis Ribeiro, Pires do Rio e Nordestina. Na direção de Itaquera, ao longo da Estrada do Imperador surge outro núcleo comercial. Já em direção ao Itaim Paulista, região de ocupação recente, a Avenida Marechal Tito mantem a característica de importante área de comércio e serviços. Pequenas indústrias localizam-se beirando a Estrada de Ferro, e os núcleos referentes a Indústria Matarazzo e Nitroquímica são ainda os mais expressivos, marcando a pequena transformação da região que possui nesta época grande parte de seu território desocupado.

97 O Centro concentra entre outros, o Hospital de São Miguel, a Capela - marco de expansão da área, a nova igreja, a Polícia Militar, uma escola e a Administração Regional - reunião de equipamentos seguindo o fator histórico de formação da região. 
No período de 1975 a $1985^{98}$, foi expressiva a expansão da rede de abastecimento de água; segundo a Secretaria Municipal de Planejamento, o problema é inexistente em toda região de São Miguel, incluindo os bairros ao redor: Jardim das Camélias, Cidade Pedro Nunes; no Parque Guarani, Vila Verde e Vila Progresso ( direção de Itaquera), no Jardim Matarazzo (direção de Ermelino Matarazzo), no Jardim Paulistano, Cidade Nitroperária e parte do Jardim Helena (extremo norte da região de São Miguel). As outras regiões são consideradas "pouco afetadas" e correspondem ao Parque Cruzeiro do Sul (oeste do centro) e região da Vila Curuçá, abrangendo o Jardim dos Ipês ( direção leste do centro de São Miguel).

Já a rede de coleta de esgoto parece ter ficado estagnada no mesmo período. A legenda da figura 4.9., expressa que o serviço é bastante precário. Ressaltamos que a consideração de toda a área em amarelo como servida é meramente pelo mapa representar a porcentagem de serviço e não a rede "rua a rua". Na verdade, se considerarmos o mapa detalhado, veremos que somente o Centro possui a rede (mantendo a condição de 1975).

Embora a rede de iluminação tenha progredido bastante (estima-se que $90 \%$ da região é servida), a área apresenta o problema do grande distanciamento entre os postes e conseqüente diminuição da intensidade luminosa.

\subsubsection{Período 1985 - 1995 - 1999}

O período de 1985-1995, reúne a maior expansão, principalmente no que tange a rede de coleta de esgotos. A área servida por rede de água que se mostrava em franca expansão na análise de 1985, é apresentada pelo Cadastro Técnico da SABESP como aproximadamente $98 \%$ provida pelo serviço. Ruas com deficiência são quase imperceptíveis e estão no final do perímetro da Vila Curuçá, a oeste da Vila Industrial.

98 Para ilustrar esse período intermediário, o esquema 4.9. mostra a situação por região e não a implantação das redes "rua a rua", mostrando apenas a condição estimada da área em intervalos expressos por: Área com rede inexistente; Área com rede $25 \%$ existente; Área com rede $50 \%$ existente; Área com rede $75 \%$ existente; Área com rede $100 \%$ existente. Os mapas foram elaborados através da "Planilha resumo" sobre os principais problemas da região de São Miguel Paulista - Ermelino Matarazzo em 1985, no relatório produzido pela Secretaria Municipal de Planejamento, publicado em 1986: PRA- Planos para Cinco Regiões Administrativas do Município de São Paulo. 
O mapa de 1995 mostra a imensa evolução na abrangência da rede de coleta de esgotos nos anos entre 1985 e 1995. Este mapa produzido pela SABESP, mostra alguns pontos sem rede na região da Vila Nair (ao norte do centro), no Jardim Helena e Vila Curuçá e a deficiência principalmente no bairro Santa Maria, a oeste do Cemitério da Saudade, que foram objeto de vistoria descrita no tópico seguinte.

Como já mencionamos no item 4.4. Características Gerais da Infra-Estrutura, a presença da rede na rua, não significa que todas as casas estão ligadas a mesma ou que recebem o serviço regularmente.

Os dados sobre a iluminação pública para 1997 são apresentados em forma de "pontos em manutenção" ou "pontos com pedido de ligação". Observamos que há uma homogeneidade na deficiência da área e que esta deficiência é semelhante a regiões centrais. Como veremos adiante, a região mais afetada com a inexistência da rede está na divisa entre o Jardim Helena e Itaim Paulista.

Com a evolução dos sistemas de telecomunicações, houve expressivo aumento na implantação de linhas telefônicas fixas e também de orelhões públicos. A tecnologia possibilitando o recebimento de chamadas através desses aparelhos também contribui para minimizar o déficit da região no tocante a comunicação . Já a rede de tv's a cabo ainda está concentrada no centro de São Miguel, provavelmente como uma relação direta com a possibilidade de arcar com despesas extras como as mensalidades oriundas do serviço, como mostra a figura 4.8.

Notamos que embora tenha havido um grande desenvolvimento das redes de primeira necessidade, o uso do solo manteve características semelhantes ao início da análise, conforme o mapa da SEMPLA de 1999, expresso pela figura 4.6.

No Centro de São Miguel; Jardim Matarazzo (direção Ermelino Matarazzo), Vila Jacuí e parte norte do Parque Paulistano há concentração de residências horizontais de médio padrão; a medida que nos distanciamos do Centro vai aumentando a predominância de áreas residências com construções horizontais de baixo padrão (Jardim dos Ipês, Jardim Helena, Jardins Santa Maria e da Casa Pintada - em direção a Itaquera). O Centro continua a concentrar a ocupação destinada a comércio e serviços; que aparecem de maneira dispersa ao longo da Marechal Tito e Avenida São Miguel. 
O uso misto - que consideramos o conjunto de ocupação combinando residências comércio, serviços, indústrias e armazéns não apresenta definição sendo bastante disperso por toda a região, inexistindo no Jardim dos Ipês, Jardins Santa Maria e da Casa Pintada e na área central do Jardim Helena.

As áreas indústrias estão a oeste do Parque Paulistano (Nitroquímica) e em outros pontos inexpressivos. Ainda existe uma área não loteada entre o Rio Tietê e o Jardim São Martinho (distrito Jardim Helena).

\subsubsection{Transformações no uso do solo no período 1968- 1999}

A região do centro de São Miguel é aquela que manteve as características de concentração de comércio e serviços apresentada desde os primórdios do bairro. Este tipo de uso foi ao longo do tempo, mediante a expansão da Vila Curuçá (Jardim dos Ipês), e do Jardim Helena, se estabelecendo na Avenida Marechal Tito e em pontos isolados da Avenida Pires do Rio. Já na Avenida São Miguel não existe uma concentração explícita de um só tipo de uso. Inicialmente em meados dos anos 80, esta avenida era utilizada predominantemente para uso residencial, o que no decorrer dessa década foi sendo mesclado com o uso comercial e acabou por receber a denominação de uso misto, que engloba a utilização residencial, comercial e industrial de forma genérica. Outros pontos que passaram por essa transformação estão distribuídos ao redor do Jardim Matarazzo, na confluência das avenidas Pires do Rio e Nordestina e com menor importância na região do Jardim da Casa Pintada (na divisão entre São Miguel Paulista e Itaquera). A consideração de uso misto também aparece de forma dispersa ao longo de todo o território do Jardim Helena de formação mais recente.

A mudança de maior impacto é representada pela própria expansão urbana da região que em um período de aproximadamente quinze anos se expandiu em todas as direções e proporcionou ao mesmo tempo uma evolução no padrão das construções ao redor da área central e em áreas do parque Paulistano (Jardim Helena) e Jardim Matarazzo (no limite entre São Miguel e Ermelino Matarazzo).

A intenção de fazer da região uma área industrial ( provavelmente pelo baixo preço dos terrenos), ficou estagnada na década de 30 com a implantação da NitroQuímica e das Indústrias Matarazzo. 

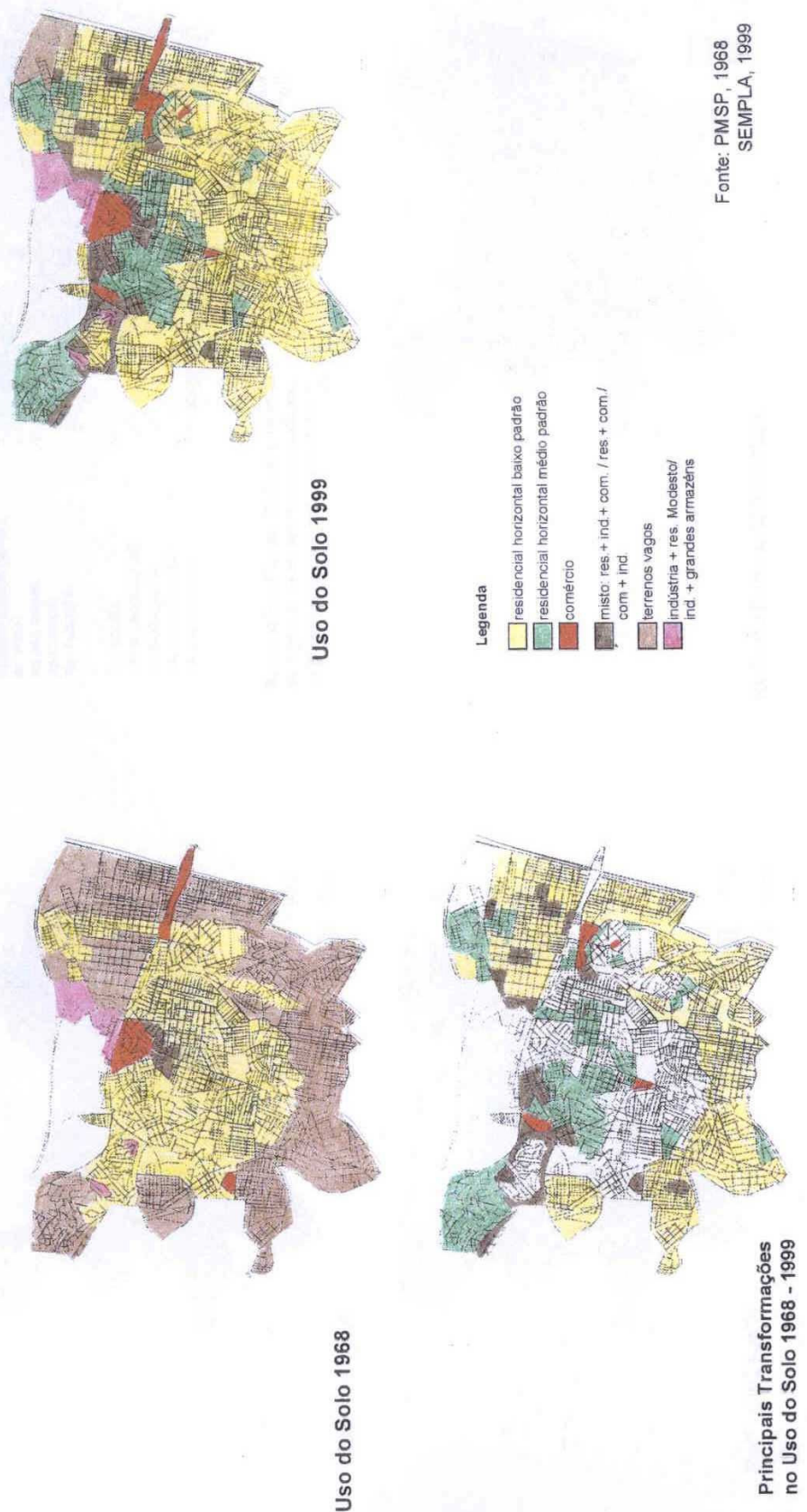

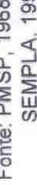

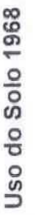

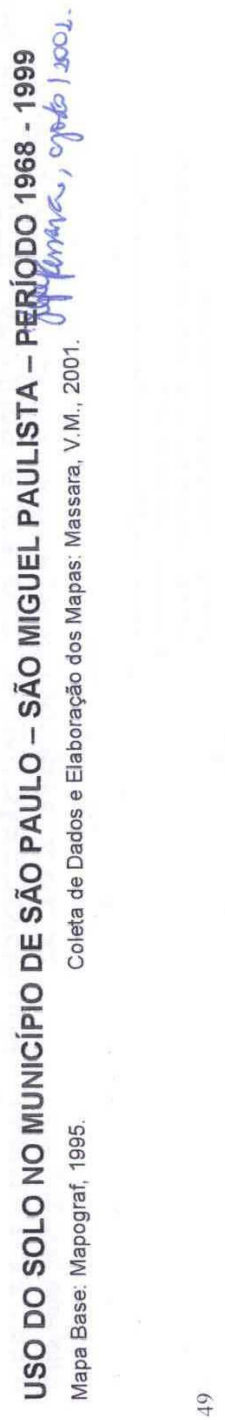

Figura 4.6. Uso do solo em São Miguel Paulista 1968-1999 (original em cópia colorida) 

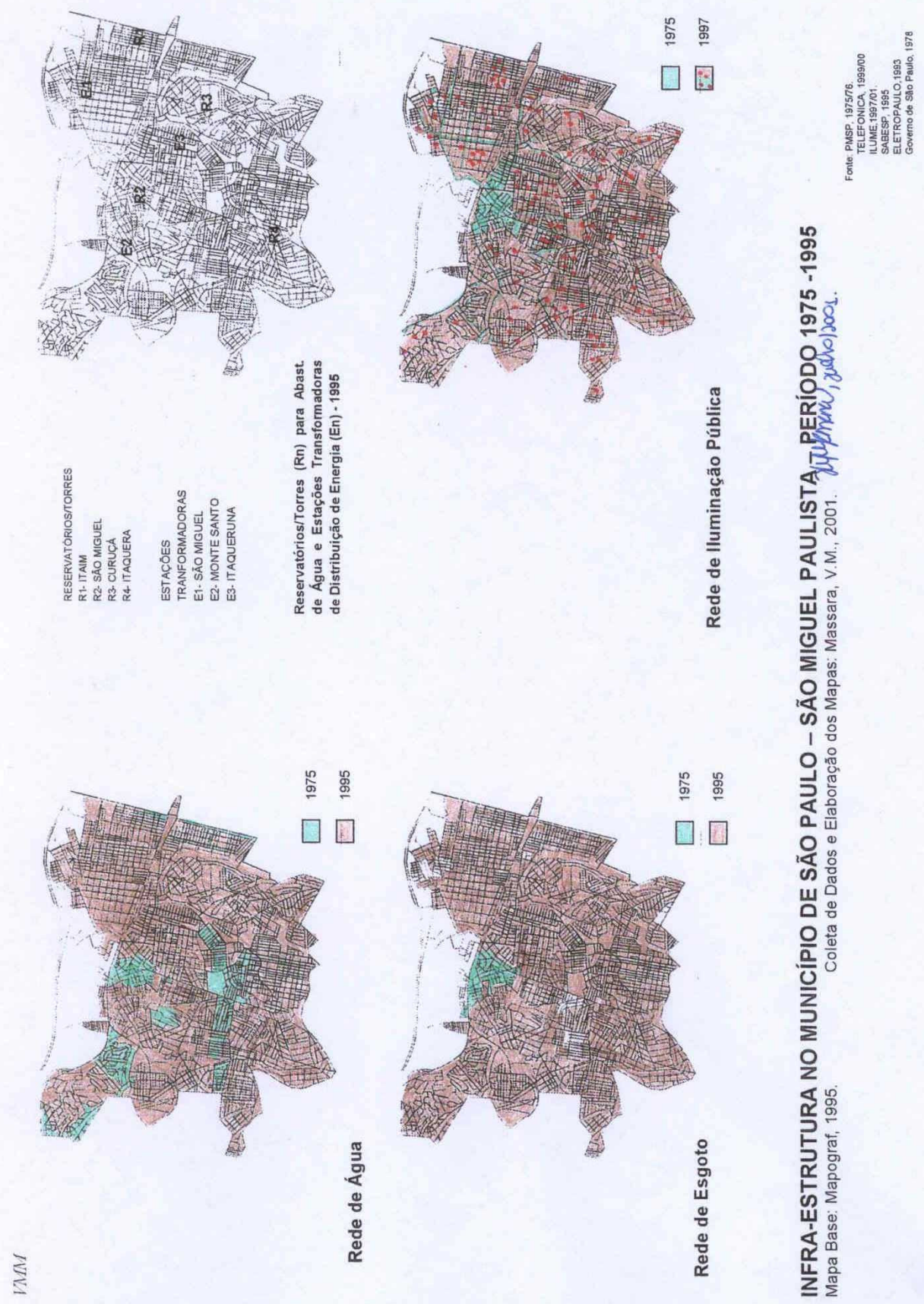

号

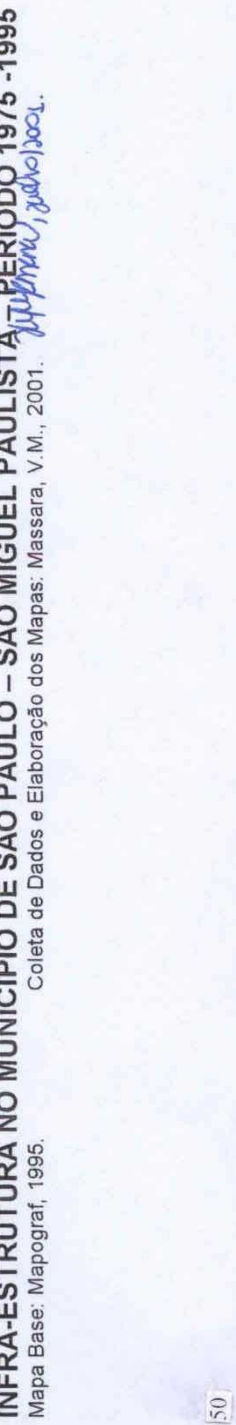

Figura 4.7. Infra-estrutura em São Miguel Paulista 1968-1999 (original em cópia colorida) 

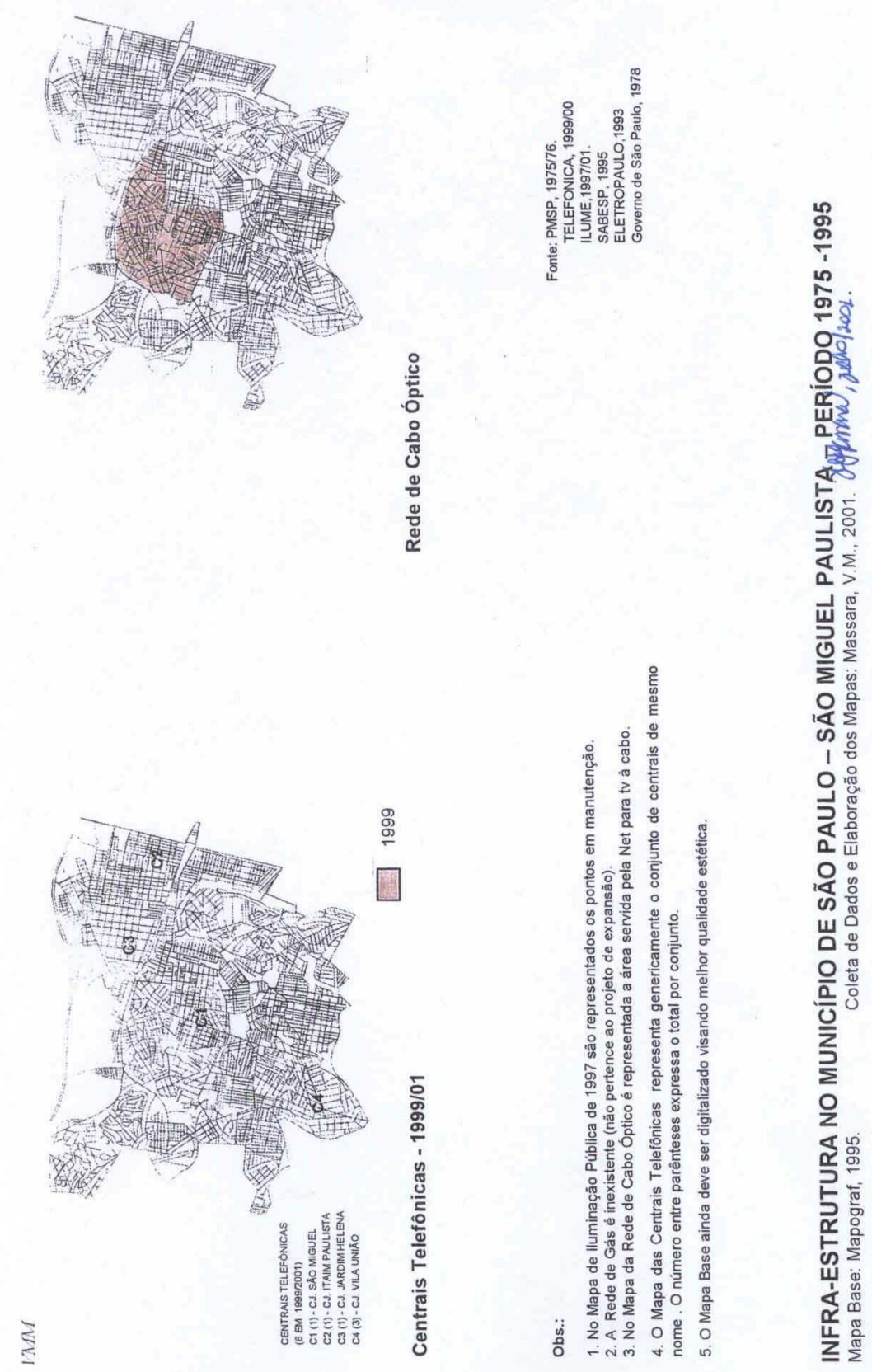

Figura 4.8. Infra-estrutura em São Miguel Paulista 1968-1999 (original em cópia colorida) 


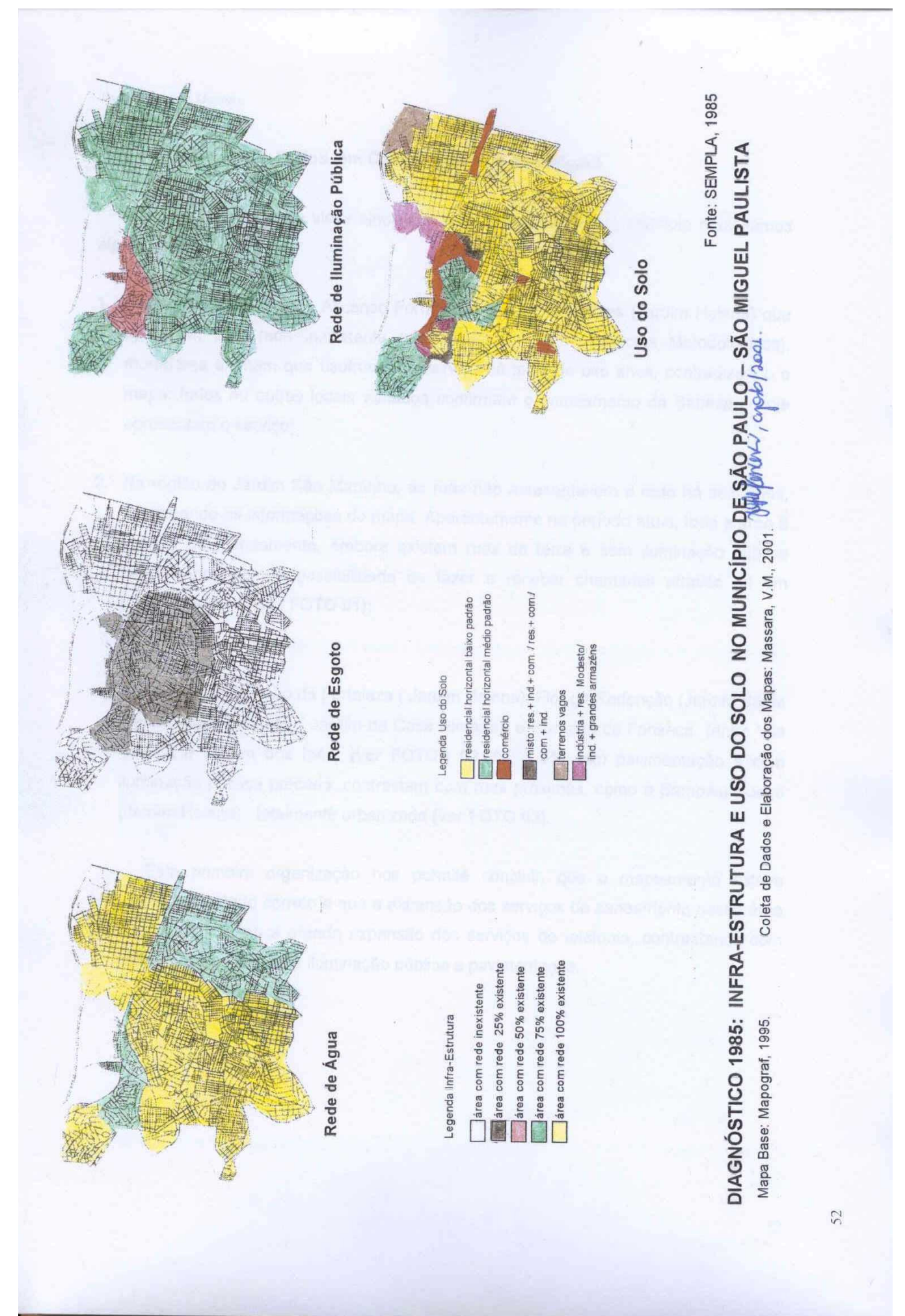

Figura 4.9. Diagnóstico 1985 Infra-estrutura e Uso do solo em São Miguel Paulista (original em cópia colorida) 


\subsubsection{Situação em 2001 - Visita a São Miguel}

Na intenção de confirmar os dados obtidos sobre a localização da infraestrutura em 1995 e sua condição, visitamos alguns endereços, selecionados segundo a ausência da rede de coleta de esgotos expressa pela figura 4.10. O objetivo dessa visita foi o de verificar locais com problemas em 1995 e a situação atual. Através de pesquisa com moradores, soubemos quais pontos do mapa da Sabesp que apresentavam deficiência nesse período e quais já usufruíam do serviço.

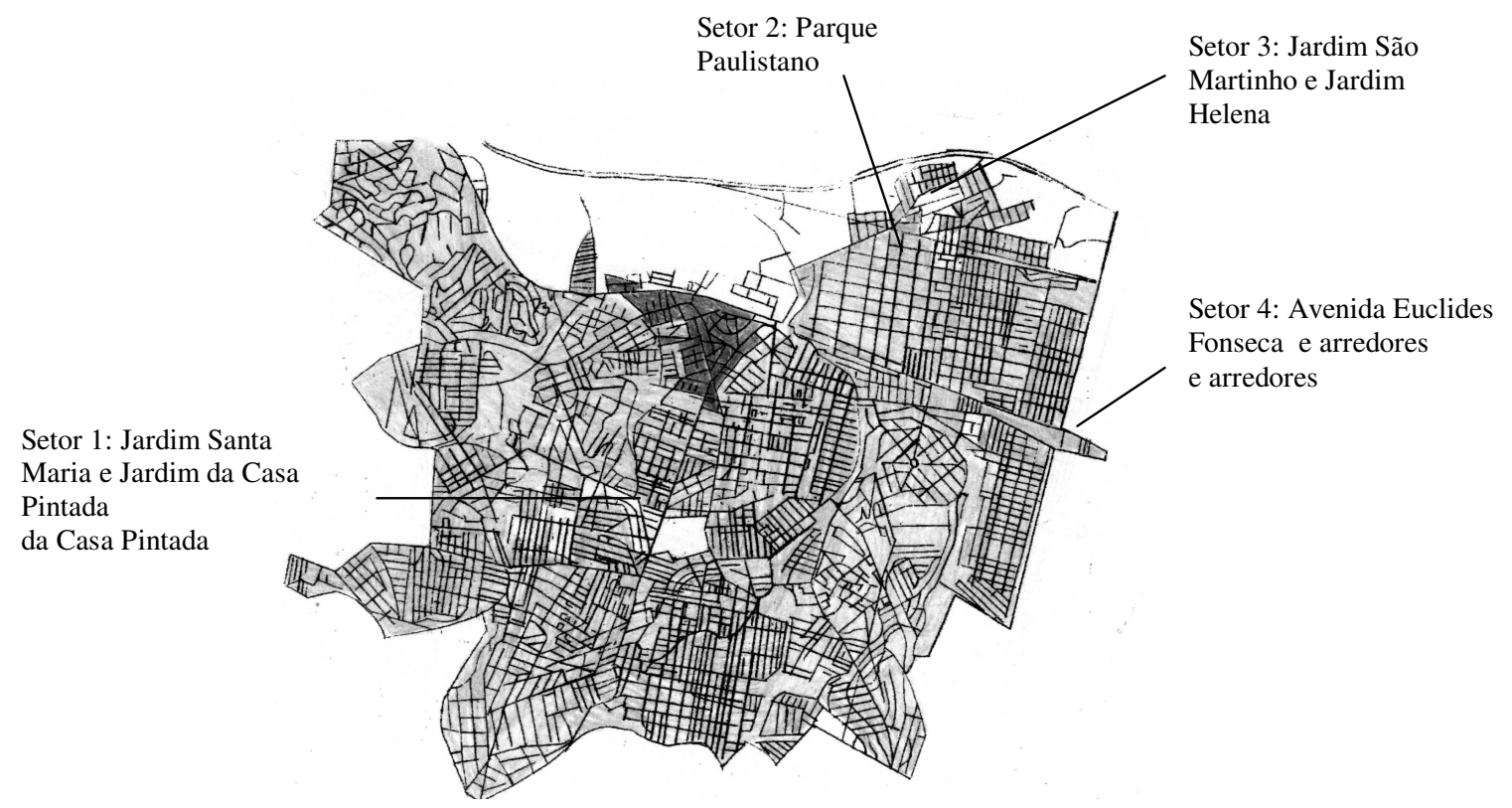

Figura 4.10. Localização dos endereços visitados ${ }^{99}$, escolhidos segundo a ausência da rede de coleta esgotos em 1995.

Elaboração: Massara, V.M., 2001.

${ }^{99}$ Endereços visitados:

- Jardim São Martinho - final da Avenida José Maria Lisboa;

- Jardim Helena: final da Avenida Ascenso Fernandes na região das ruas Cruzeiro da Fortaleza, Rio das Pedras, Eng ${ }^{\circ}$. Álvaro de Oliveira, Tinguaçú e Avenida Felix Nascentes;

- Parque Paulistano: Ruas Sampaio Bueno, Guaracapanema e Monsenhor Lourenço;

- Entre o Jardim dos Ipês e a Vila Curuçá: Ruas Euclides Fonseca e Elias Monteiro Cardoso (travessa da Avenida Marechal Tito);

- Jardim da Casa Pintada: Avenida Maria Santana;

- Jardim Santa Maria: Ruas Folha da Fonte, Folha de Santana, Flor Cachimbo, Fruta do Paraíso, Flor da Redenção, Flor da Ressurreição, Flor do Espírito e Rua Jasmim de Porcelana (nos quarteirões entre a Avenida Maria Santana e a Estrada do Imperador). 


\section{Infra-estrutura}

\section{Setor 3: Jardim Helena e Jardim São Martinho}

$\mathrm{Na}$ região das Avenidas Ascenso Fernandes e Felix Nascentes (Jardim Helena) que aparecem com rede inexistente na figura 4.10., moradores afirmam que usufruem do serviço há mais de oito anos, contradizendo o mapa; todos os outros locais visitados confirmam o mapeamento da Sabesp e hoje apresentam o serviço;

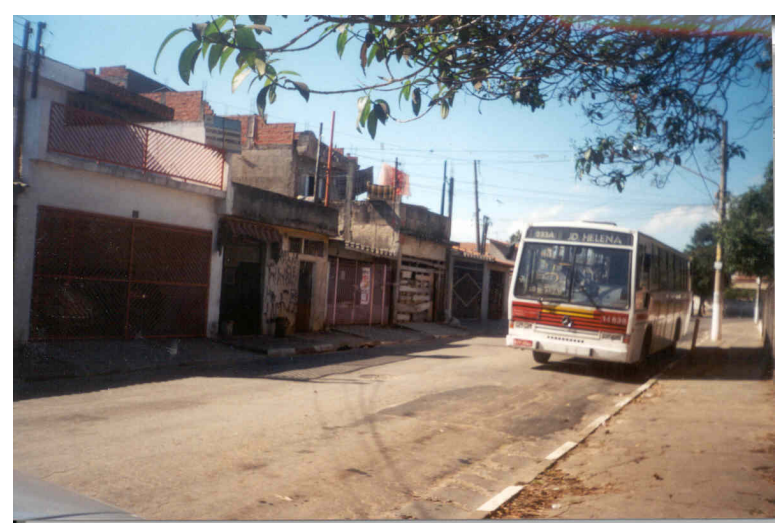

Foto 4.1. Avenida Ascenso Fernandes - ponto final do ônibus Jardim Helena - Parque Dom Pedro

Fonte: Massara, V.M., 2001.

Na região do Jardim São Martinho, as ruas não apresentavam a rede há seis anos, confirmando as informações do mapa. Aparentemente no período atual, toda a área é servida por saneamento, embora existam ruas de terra e sem iluminação pública contrastando com a possibilidade de fazer e receber chamadas através de um telefone público.

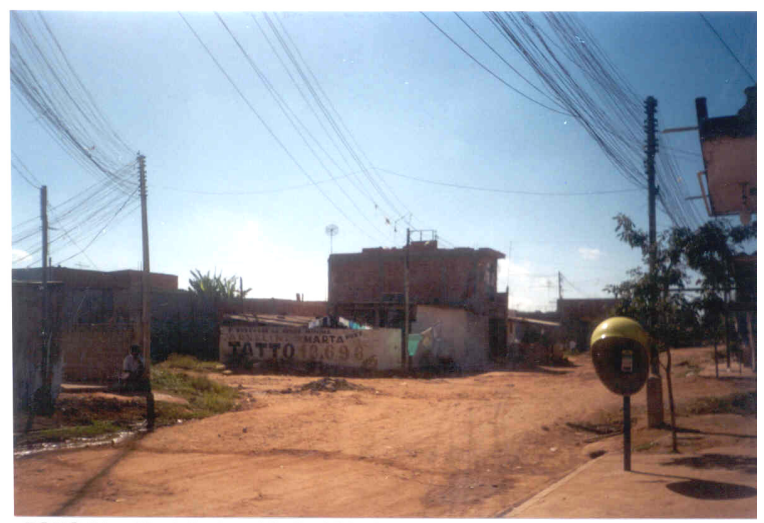

Foto 4.2. Final da Avenida José Maria Lisboa - Jardim São Martinho (distrito Jardim Helena)

Fonte: Massara, V.M., 2001. 
Ruas como a Cruzeiro da Fortaleza ( Jardim Helena), Flor da Redenção (Jardim Santa Maria), Maria Santana ( Jardim da Casa Pintada) e Euclides da Fonseca (entre Vila Curuçá e Jardim dos Ipês) sem pavimentação e com iluminação pública precária, contrastam com ruas próximas, como a Sampaio Bueno (Jardim Helena), totalmente urbanizadas.

Setor 1: Jardim Santa Maria e Jardim Da Casa Pintada

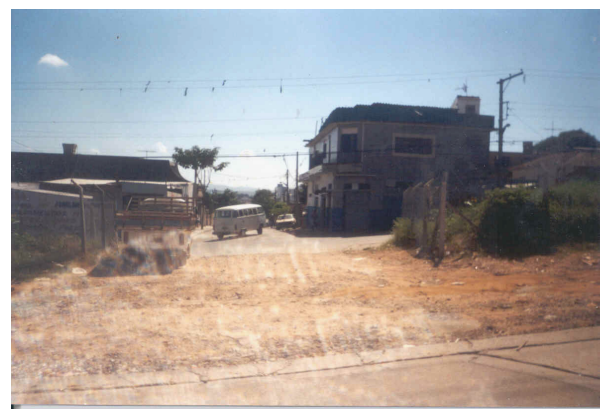

Foto 4.3. Rua Flor da Redenção

\section{Setor 2: Parque Paulistano}

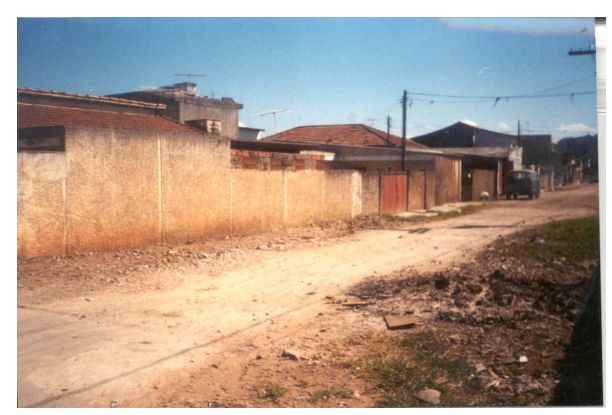

Foto 4.5. Rua Cruzeiro da Fortaleza Fonte: Massara, V.M., 2001.
Setor 4: Avenida Euclides Fonseca e arredores

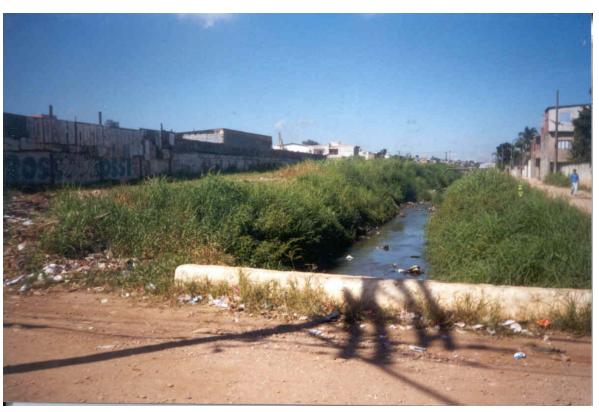

Foto 4.4. Avenida Euclides Fonseca

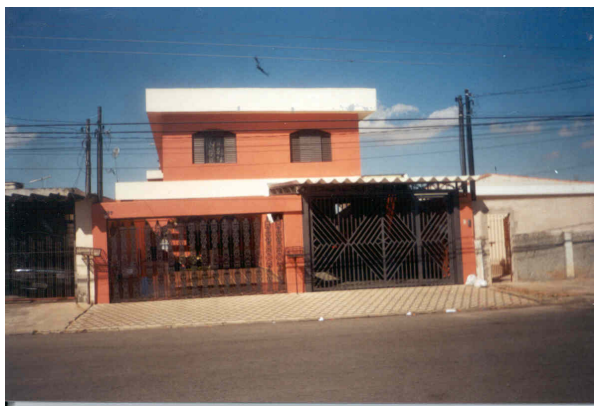

Foto 4.6. Rua Sampaio Bueno

Esta visita nos permitiu concluir, que o mapeamento estava praticamente todo correto e que a expansão dos serviços de saneamento nessa área é total, contrastando com problemas nas redes de iluminação pública e pavimentação e com a grande expansão dos serviços de telefonia. 


\section{Uso do solo}

Mantendo as características do mapeamento de 1999, a verificação in loco sobre as transformações no uso do solo, apresenta construções residenciais de no máximo dois pavimentos, seguindo a distribuição territorial pelo padrão social já descrito; um ponto marcante é a utilização para pequeno comércio das garagens de casas, ocorrência mais comum no Jardim Helena, ponto extremo e bastante distante do centro.

Em toda a região, a concentração de grandes super e hipermercados, lojas de carros, material de construção e móveis é localizada nas Avenidas Marechal Tito e São Miguel; um comércio de menor porte, menos sofisticado mas bem diversificado, é encontrado ao longo da Avenida Pires do Rio e Estrada do Imperador, indicando uma correspondência direta entre o tipo de serviço e a distância ao centro de São Miguel.

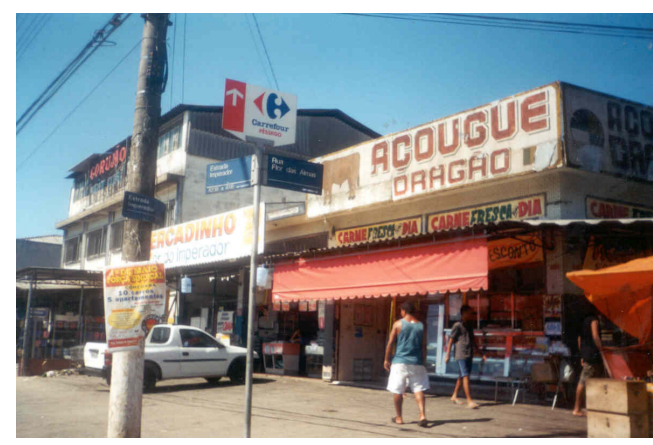

Foto 4.7. Estrada do Imperador

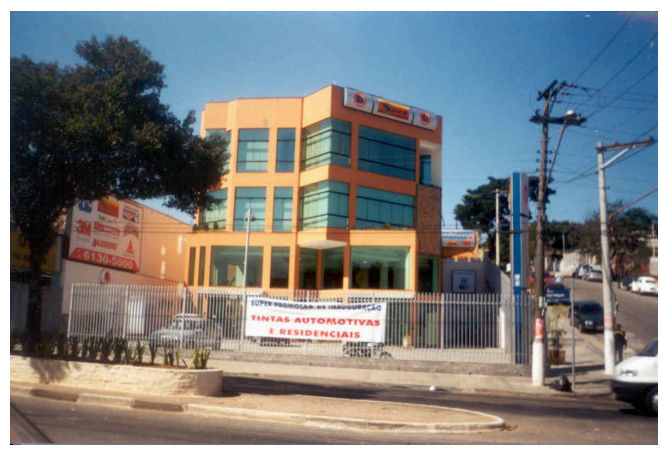

Foto 4.9. Avenida São Miguel

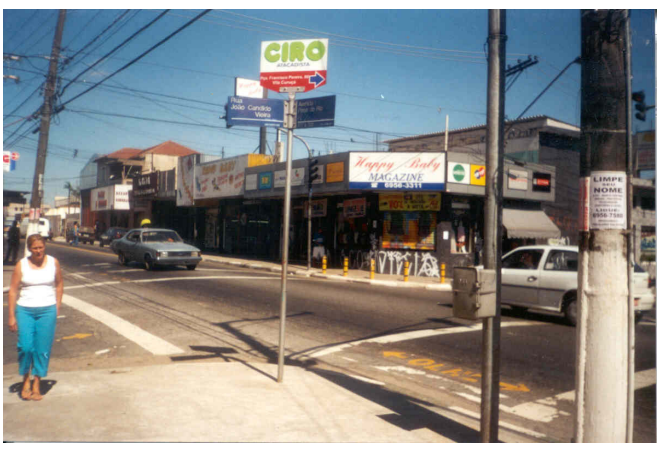

Foto 4.8. Avenida Pires do Rio

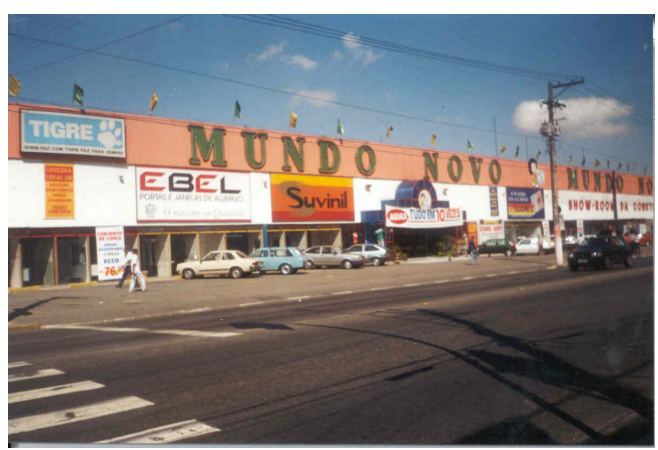

Foto 4.10. Avenida Marechal Tito

Fonte: Massara, V. M., 2001. 


\subsubsection{A relação entre o uso do solo e a presença de infra-estrutura}

Através da análise das figuras de uso do solo e infra-estrutura, combinadas ao histórico de expansão da região:

- fica evidente que nessa região a infra-estrutura (saneamento e energia) foi secundária para seu desenvolvimento econômico. O centro comercial já estava estabelecido há vários anos quando a rede de abastecimento de água começou a ser instalada;

- considerando a grande expansão populacional e territorial da década de 70 , todas as redes apresentaram expansão tardia, mostrando problemas na implantação dos serviços em relação a ocupação do solo;

- indústrias de grande porte possuem infra-estrutura própria;

- a implantação das redes segue a seqüência territorial de expansão, ou seja, parte do centro, sendo expandida de forma concêntrica a essa área;

- confirmando a premissa anterior, os primeiros locais a receberem infra-estrutura são aqueles utilizados para uso comercial e prestação de serviços (localizados no centro);

- nessa região, não conseguimos estabelecer a ordem de aparecimento das redes de água e energia elétrica, embora através de consulta a Eletropaulo tenha ficado implícita a idéia que o serviço que melhor acompanhou a expansão da mancha urbana foi o de energia; o último serviço de primeira necessidade a ser instalado é a rede de coleta de esgotos;

- a verificação in loco (2001) permite dizer que os maiores déficits estão concentrados em iluminação pública e pavimentação; a rede de telefonia fixa também não está totalmente difundida embora seja claro o avanço social possibilitado pelos telefones públicos que recebem chamadas;

- o estudo apontou a preponderância dos fatores localização e acessibilidade como importantes agentes na implantação das redes. 


\section{Capítulo 5. Considerações finais}

"O homem urbano, no exercício de suas diversas atividades (econômicas ou não), utiliza-se diretamente da terra como apoio físico. Uma vez que o exercício dessas atividades exige a introdução de melhoramentos sobre a terra, há uma íntima correlação entre as atividades humanas e os melhoramentos que o homem necessita introduzir sobre a terra para poder exercêlas.”

(VILLAÇA, 1968, p.9).

De maneira geral, a implantação das infra-estruturas tem início no local mais antigo da cidade e que acaba constituindo o "centro". O sentido natural de sua evolução considera esse marco e a partir dele as facilidades técnicas de prolongamento das tubulações (como por exemplo a topografia), o custo de cada serviço (o que explica porque a energia elétrica e o abastecimento de água chegam antes da rede coletora de esgotos) e a concentração populacional gerada pelo próprio histórico de criação e desenvolvimento dos bairros ao redor do ponto inicial.

Neste estudo constatamos (como ilustram as figuras do capítulo 2 sobre a evolução da distribuição territorial das redes) que a instalação dos serviços começou na área central da cidade, estendendo - se de forma aproximadamente concêntrica ao redor desse primeiro centro, abrangendo a região atualmente denominada por centro expandido.

Após a década de 70 a implantação vai se consolidando na região periférica da cidade, principalmente nas zonas sul e leste, as menos atendidas até então.

\subsection{Os fatores de implantação da infra-estrutura ${ }^{100}$}

Densidade construída e densidade demográfica

A determinação dos locais a serem atendidos pelas redes leva em conta vários critérios. Partindo da área mais antiga e conseqüentemente com maior população, a demanda é o primeiro critério considerado.

\footnotetext{
${ }^{100}$ Um estudo minucioso que permita determinar o peso de cada componente na rapidez de instalação dos serviços é bastante complexo e não foi o objeto desta pesquisa.
} 
Conforme o Plano Urbanístico Básico (PMSP, 1968, p.43), a ocupação rarefeita das áreas periféricas e a deficiência de recursos financeiros fez com que apenas uma região reduzida, mais próxima do centro, fosse atendida pelos serviços públicos como água, esgotos, gás, iluminação pública e coleta de lixo, localizando os maiores índices de atendimento na região central da cidade. ${ }^{101}$

$\mathrm{Na}$ escolha das duas áreas de estudo, fica evidente que a época de maior expansão de São Miguel Paulista ocorreu décadas após a consolidação do centro expandido e de seu processo de verticalização e conseqüente aumento da densidade construída, justificando em parte a diferença de períodos na implantação de infraestrutura.

Por outro lado, a implantação das redes na região do extremo leste estudada aqui, apresentou ênfase nas décadas de 80 e 90 não acompanhando a expansão demográfica iniciada nas décadas de 60 e 70 (que não foi representada por verticalização).

\section{Localização e acessibilidade}

Considerando a localização e a possibilidade de acesso como importantes agentes de transformação dos $\operatorname{usos}^{102}$, levando em conta o tempo e custos de deslocamentos para chegar a áreas com concentração de empregos, o "centro" tem papel relevante na atração dos serviços.

Estar no "centro", além de propiciar o fácil acesso a qualquer região da cidade e permitir a utilização de serviços e equipamentos sofisticados, determina na maior parte das vezes o status social ${ }^{103}$.

Através da história do Município conclui-se que a escolha por locais próximos ao centro comercial, com ruas pavimentadas e servidas por vários tipo de transportes, marcam o processo de valorização imobiliária ${ }^{104}$, tendo o vetor oeste da cidade a prioridade na instalação das redes.

\footnotetext{
${ }^{101}$ Vide PMSP (1986); ROLNIK et al. (1991); SEMPLA (2000, vol.3).

${ }^{102}$ Vide VILLAÇA $(1968 ; 1998)$.

${ }^{103}$ Vide SANTOS (1987).

${ }^{104}$ Vide ROLNIK (1997).
} 


\section{Distribuição de renda}

Como resultante direta do histórico de expansão da cidade, surge a variável distribuição de renda ${ }^{105}$ como fator de atração para implantação das redes e sofisticação dos usos.

Formando um círculo vicioso, a consolidação do centro e conseqüente atração de serviços urbanos e diferentes usos concentra de forma geral nas suas proximidades, a população de maior poder aquisitivo e acaba por "expulsar" os mais pobres para a periferia longínqua e desprovida de equipamentos. ${ }^{106}$

Ao compararmos o centro expandido com a região de São Miguel Paulista, verificamos que a ênfase dada a implantação pode estar ligada a possibilidade de consumir e pagar pelo serviço; isto também pode ser constatado dentro do próprio centro, na ênfase em suprir os bairros comerciais e de classe média alta.

\section{Facilidades técnicas e custos de implantação}

Partindo do núcleo central, fica implícita a idéia de que a instalação das redes se torna mais simples e barata ao redor da região já servida, o que justifica a maior rapidez com a qual os bairros em torno desse primeiro núcleo receberam os serviços.

Da mesma forma, a seqüência de implantação das redes segue as facilidades e também o custo de implantação ${ }^{107}$ e que de modo geral, apresenta a seguinte ordem 108 para os serviços de primeira necessidade: energia elétrica, abastecimento de água, coleta de esgotos e iluminação pública, independente da região.

\section{A utilização das redes na área central da cidade}

A cobertura dos serviços nas áreas centrais oriunda dos fatores já mencionados, leva a crer que ao invés de expandir a ocupação urbana em direção a regiões periféricas e desprovidas dos serviços, deve-se aproveitar a infra-estrutura já instalada no centro da cidade. Esta afirmação nos remete ao conceito de "potencial de adensamento" 109 , ou seja, o estudo da capacidade das redes em cada região versus o seu efetivo uso, exigindo uma complexa verificação não somente de sua

\footnotetext{
${ }^{105}$ Vide VETTER e MASSENA (1975).

${ }^{106}$ Vide GARCIAS (1991); ROLNIK et al. (1991); MORETTI (1993); ROLNIK (1997);

${ }^{107}$ Vide MASCARÓ (1979; 1987; 1991).

${ }^{108}$ Vide Plano Urbanístico Básico (PMSP, 1968); ELETROPAULO (entrevista, 2000).

109 Vide RONCA e ZMITROWICZ (1988); PROENÇA (1992); GUALDA (1992); MIGLIORINI (1997).
} 
capacidade como também da condição física de cada tipo de infra-estrutura em separado, pois nem todas as redes permitem maior utilização (como por exemplo, a rede de energia elétrica).

\section{Planejamento: a expansão da periferia}

Em oposição as questões indicadas anteriormente, que induzem a conclusão de que o centro foi beneficiado em detrimento a periferia, devemos mencionar que um fator decisivo para a qualidade dos serviços em regiões periféricas é a sua expansão desordenada e muitas vezes clandestina. Conforme a SEMPLA (2000, vol.3, p.10) a extensão de redes de serviços públicos a distâncias sempre maiores, exige grandes investimentos, seja por parte da Prefeitura, seja por parte do Estado e gera uma situação de contínuo descompasso entre as possibilidades reais de atendimento e as necessidades da população carente, indicando que a falta de ordenação principalmente das áreas sul e leste de São Paulo, influenciaram a demora na instalação de infra-estrutura mesmo em áreas já densamente habitadas.

De forma resumida o esquema ilustrado a seguir, inter-relaciona todos os aspectos que determinam a implantação das redes em regiões centrais e periféricas .

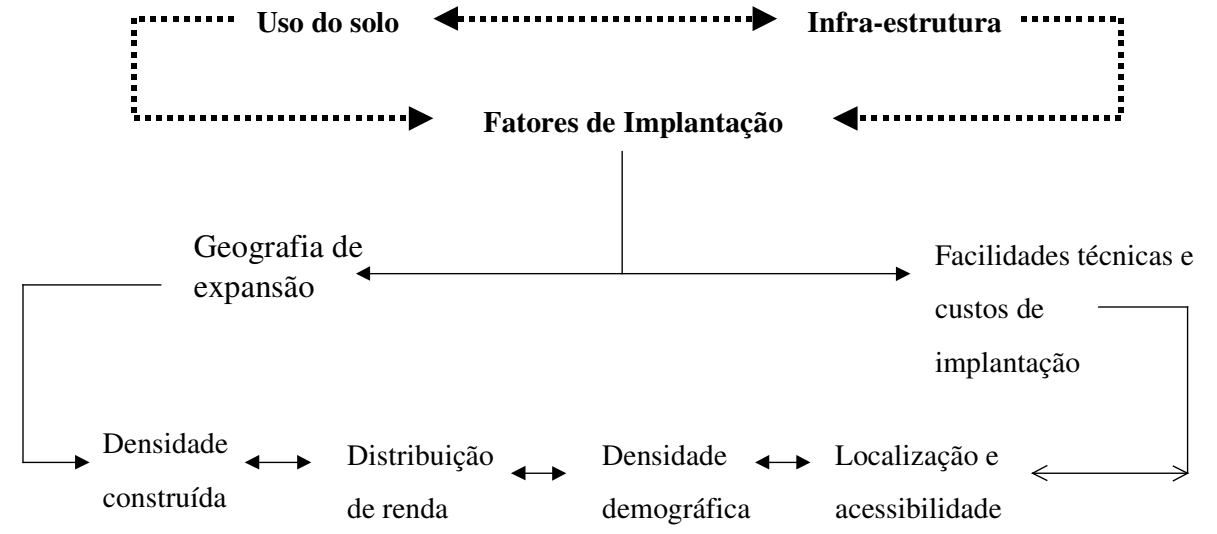

Figura 5.1. O uso do solo como atrativo para implantação da infra-estrutura.

Elaboração: Massara, V.M., 2002.

\subsection{A relação entre a existência de infra-estrutura e as transformações de uso do solo}


Consideramos que a análise da evolução urbana através dos sistemas de infraestrutura é de suma importância para o entendimento da influência que estes exercem sobre a qualidade de vida da população e o desenvolvimento da cidade.

Como projeto de mestrado, realizamos o levantamento da implantação das redes de infra-estrutura (saneamento, energia e telecomunicações) no Município de São Paulo e seu mapeamento detalhado para as regiões do centro expandido e de São Miguel Paulista, visando estipular a relação entre as modificações no uso do solo e a presença das redes em diferentes períodos e áreas da cidade.

Partindo da premissa que existe relação entre ambos, procuramos verificar qual a sua importância. Usando como principal instrumento a análise de informações gráficas, através da introdução de dados sobre a evolução das redes em um determinado período de transformação do uso do solo, chegamos a conclusão que a influência desse tipo de infra-estrutura é secundária na determinação da ocupação de uma área. Nas duas regiões, verificou-se que normalmente primeiro se instala o uso e este atrai a implantação dos serviços, principalmente em função das características econômicas da área, como enfatiza TOLEDO SILVA (1995, p.19): “a infra-estrutura é implantada principalmente em função das necessidades da atividade econômica e do consumo, e não necessariamente em benefício das comunidades residentes por onde ela passa".

Podemos dizer que a introdução das infra-estruturas em uma determinada região funciona como uma "vantagem competitiva" na atração de usos, resultando na sofisticação dos usos já instalados.

A importância da infra-estrutura é difícil de ser mensurada por muitas vezes estar ligada a fatores de caráter subjetivo, como o que cada um entende por qualidade de vida conforme sua realidade. A necessidade do serviço muda conforme o período ou região de estudo. Assim por exemplo, a importância dada ao saneamento básico no centro histórico data de início do século, já para os distritos ao redor desse primeiro núcleo se concentra entre as décadas de 20 e 50, enquanto que para a região de São Miguel Paulista, essa questão tomou vulto a partir da década de $60 .^{110}$

${ }^{110}$ Esta observação está diretamente associada as diferentes fases de incremento demográfico de cada região. 
O esquema ${ }^{111}$ seguinte resume a idéia:

\begin{tabular}{|c|c|c|c|c|c|}
\hline $\begin{array}{l}\text { Região } \\
\text { estudo }\end{array}$ & \begin{tabular}{l|l} 
de & $\begin{array}{l}\text { Tipo de infra- } \\
\text { estrutura }\end{array}$ \\
\end{tabular} & $\begin{array}{l}\text { Período de ênfase na importância da } \\
\text { infra-estrutura }\end{array}$ & $\begin{array}{l}\text { Importância da infra-estrutura por } \\
\text { tipo de uso do solo }\end{array}$ & Necessidade & Observações \\
\hline \multirow{7}{*}{ Central } & energia elétrica & início do século $\mathrm{XX}$ até período atual & todos & $\begin{array}{l}\text { bem de consumo } \\
\text { insumo de produção }\end{array}$ & \\
\hline & \begin{tabular}{|l|} 
abastecimento \\
água
\end{tabular} & início do século XX até a década de 50 & todos & $\begin{array}{l}\text { saúde pública } \\
\text { bem de consumo } \\
\text { insumo de produção }\end{array}$ & $\begin{array}{l}\text { nessa região, em geral de lotes regularizados, a } \\
\text { utilização de poços era menos perigosa }\end{array}$ \\
\hline & coleta de esgotos & início do século $\mathrm{XX}$ até a década de 50 & todos & $\begin{array}{l}\text { saúde pública } \\
\text { saneamento ambiental }\end{array}$ & $\begin{array}{l}\text { nessa região, em geral de lotes regularizados, a } \\
\text { utilização de fossas era menos perigosa }\end{array}$ \\
\hline & $\begin{array}{l}\text { iluminação } \\
\text { pública }\end{array}$ & início do século $\mathrm{XX}$ até período atual & todos & bem de consumo & $\begin{array}{l}\text { em qualquer época para efeito de segurança, } \\
\text { nessa região em especial de grande tráfego de } \\
\text { veículos }\end{array}$ \\
\hline & telefonia & décadas de 30 a 80 & $\begin{array}{l}\text { todos } \\
\text { com maior ênfase na prestação } \\
\text { de serviços }\end{array}$ & $\begin{array}{l}\text { insumo de produção } \\
\text { (indireto) } \\
\text { bem de consumo }\end{array}$ & $\begin{array}{l}\text { perdendo a importância com a introdução dos } \\
\text { aparelhos móveis; é uma vantagem competitiva }\end{array}$ \\
\hline & cabo óptico & década de 80 até período atual & $\begin{array}{l}\text { com maior ênfase na prestação } \\
\text { de serviços }\end{array}$ & $\begin{array}{l}\text { insumo de produção } \\
\text { (indireto) } \\
\text { bem de consumo }\end{array}$ & $\begin{array}{l}\text { para o agrupamento de cabos de energia elétrica e } \\
\text { telefonia e no aumento de velocidade de } \\
\text { transmissão de dados computacionais e imagem; } \\
\text { é uma vantagem competitiva }\end{array}$ \\
\hline & gás canalizado & sem data específica & $\begin{array}{l}\text { com maior ênfase nos usos } \\
\text { industrial e comercial }\end{array}$ & $\begin{array}{l}\text { insumo de produção } \\
\text { bem de consumo }\end{array}$ & $\begin{array}{l}\text { em áreas residenciais apenas como um fator de } \\
\text { comodidade; é uma vantagem competitiva }\end{array}$ \\
\hline
\end{tabular}

Tabela 5.1. Importância da infra-estrutura segundo região, período de estudo e uso do solo.

Elaboração: Massara, V.M., 2002.

${ }^{111}$ Este quadro foi obtido através das conclusões retiradas dos capítulos 3 e 4, sobre a relação entre o uso do solo e a presença de infra-estrutura em duas regiões de características históricas diferentes. 
Tabela 5.1. Importância da infra-estrutura segundo região, período de estudo e uso do solo (continuação).

Elaboração: Massara, V.M., 2002.

\begin{tabular}{|c|c|c|c|c|c|}
\hline $\begin{array}{ll}\text { Região } & \text { de } \\
\text { estudo }\end{array}$ & \begin{tabular}{|l} 
Tipo de infra- \\
estrutura
\end{tabular} & $\begin{array}{l}\text { Período de ênfase na importância da } \\
\text { infra-estrutura }\end{array}$ & $\begin{array}{l}\text { Importância da infra-estrutura por } \\
\text { tipo de uso do solo }\end{array}$ & Necessidade & Observações \\
\hline \multirow{7}{*}{ Periférica } & energia elétrica & início do século XX até período atual & todos & $\begin{array}{l}\text { bem de consumo } \\
\text { insumo de produção }\end{array}$ & \\
\hline & \begin{tabular}{|l|} 
abastecimento \\
água
\end{tabular} & após a década de 60 & todos & $\begin{array}{l}\text { saúde pública } \\
\text { bem de consumo } \\
\text { insumo de produção }\end{array}$ & $\begin{array}{l}\text { nessa região, em geral de lotes não regularizados } \\
\text { e de dimensões ínfimas, a utilização de poços é } \\
\text { bastante perigosa }\end{array}$ \\
\hline & coleta de esgotos & após a década de 60 & todos & $\begin{array}{l}\text { saúde pública } \\
\text { saneamento ambiental }\end{array}$ & $\begin{array}{l}\text { nessa região, em geral de lotes não regularizados } \\
\text { e de dimensões ínfimas, a utilização de fossas é } \\
\text { bastante perigosa }\end{array}$ \\
\hline & $\begin{array}{l}\text { iluminação } \\
\text { pública }\end{array}$ & após a década de 60 & todos & bem de consumo & $\begin{array}{l}\text { em qualquer época para efeito de segurança, } \\
\text { nessa região em especial, onde pedestres } \\
\text { percorrem várias quadras até o transporte coletivo }\end{array}$ \\
\hline & telefonia & após a década de 60 & $\begin{array}{l}\text { todos } \\
\text { com maior ênfase na prestação } \\
\text { de serviços }\end{array}$ & $\begin{array}{l}\text { insumo de produção } \\
\text { (indireto) } \\
\text { bem de consumo }\end{array}$ & $\begin{array}{l}\text { a prestação de serviços é praticamente } \\
\text { inexistente; é uma vantagem competitiva }\end{array}$ \\
\hline & cabo óptico & década de 80 até período atual & $\begin{array}{l}\text { com maior ênfase na prestação } \\
\text { de serviços }\end{array}$ & $\begin{array}{l}\text { insumo de produção } \\
\text { (indireto) } \\
\text { bem de consumo }\end{array}$ & a prestação de serviços é praticamente inexistente \\
\hline & gás canalizado & sem data específica & $\begin{array}{l}\text { com maior ênfase nos usos } \\
\text { industrial e comercial }\end{array}$ & $\begin{array}{l}\text { insumo de produção } \\
\text { bem de consumo }\end{array}$ & $\begin{array}{l}\text { os usos industrial e comercial são praticamente } \\
\text { inexistentes }\end{array}$ \\
\hline
\end{tabular}


A influência do tipo de uso do solo na utilização da infra-estrutura

As áreas de maior expansão do uso terciário são aquelas que primeiro recebem as redes. O maior consumidor entre os tipos de uso do solo é o residencial, seguido pela utilização comercial e de prestação de serviços e em último lugar pelo uso industrial.

Considerando as duas regiões delimitadas para esta pesquisa, o consumo de água para fins comerciais é relevante nas regiões central (margem esquerda do rio Tietê) e dos Jardins (margem direita do rio Pinheiros), assim como em toda área residencial de alto poder aquisitivo ${ }^{112}$ (relação renda versus consumo).

No campo da energia elétrica o consumo residencial de classe média e alta, determinou que o centro expandido chegasse ao limite de fornecimento, gerando problemas na expansão das transmissões devido a escassez de terrenos nas áreas centrais para construção de novas estações transformadoras. Da mesma forma, a concentração de linhas telefônicas está no centro expandido, em grande parte para uso residencial e de prestação de serviços. Na periferia, a concentração ocorre no uso residencial.

Constatamos que o agrupamento de diferentes usos em uma mesma região atrai maior atenção na implantação das infra-estruturas. Os usos comercial e residencial de alto padrão foram os principais responsáveis pela rapidez na instalação das infra-estruturas.

Atualmente redes como cabo óptico exercem tal influência que determinam a modificação dos novos escritórios: menores e mais funcionais.

Através desta breve análise, fica explícito que existe uma relação de maior peso envolvendo as transformações de uso do solo e conseqüente implantação das infra-estruturas. Essa relação é baseada no conjunto de características da cidade a começar pela implantação de seu núcleo inicial e consolidação do "centro" culminando com o direcionamento de investimentos visando o setor imobiliário e sua valorização no setor oeste da cidade.

${ }^{112}$ Para definir com maior exatidão as áreas de maior consumo foram criadas as "curvas de isoconsumo" expressas por $\mathrm{m} 3$ / hab / dia. Essas curvas associam o uso do solo, com o nível de renda e densidade de ocupação. Vide NUCCI (Revista R.A.E., 1983, n.135). 
A localização e concentração de renda não são necessariamente preponderantes na determinação dos locais que receberão os serviços e na rapidez com os quais serão instalados.

As dificuldades construtivas e a própria expansão rápida e desordenada da cidade impossibilitam o fluxo direto de implantação e criam problemas maiores como o constante investimento em áreas com déficits e o abandono de outras questões (como a proteção aos mananciais).

Concluímos que o processo de implantação das redes é dependente de diversos fatores que geram um círculo complexo de interesses e real necessidade dos serviços.

Outro ponto relevante está em, ao mesmo tempo que se faz necessário estender os serviços por todo o Município, também é necessária a manutenção da rede antiga.

Equilibrar a expansão da cidade com o seu desenvolvimento continuará a ser um desafio neste novo século. 


\section{Bibliografia}

ABIKO, Alex Kenya. Serviços Públicos Urbanos. São Paulo, Texto Técnico, Escola Politécnica da Universidade de São Paulo, n.10, 1995.

AZEVEDO, Aroldo de. (org). A Cidade de São Paulo. São Paulo, Associação dos Geógrafos brasileiros, Companhia Editora Nacional, 1958. Vol II, III, IV.

AZEVEDO NETTO, José M.; NADRUZ, Nassim. A estação de tratamento de esgotos de Vila Leopoldina. Revista do DAE . São Paulo, Repartição de Águas e Esgoto de São Paulo - Secretaria de Viação e Obras Públicas. Número 31, Julho, 1958, p.V-XVI.

AZEVEDO NETTO, José M. Cronologia do abastecimento de água até 1970. Revista do DAE . São Paulo, Repartição de Águas e Esgoto de São Paulo Secretaria de Viação e Obras Públicas. Número 137, Julho, 1984.

ALONSO, William. Location and land use. Cambridge, Harvard University Press, 1964.

ANDRADE, Francisco de Paula Dias de. Subsídios para o estudo da influência da legislação na ordenação e na arquitetura das cidades brasileiras. São Paulo, Tese (Livre Docência), Escola Politécnica da Universidade de São Paulo, 1966, pg. 264/272.

ASSOCIAÇÃO BRASILEIRA DE ENGENHARIA SANITÁRIA. Resultados recentes do desenvolvimento da solução integrada de esgotos da grande SP. São Paulo, 1976.

BARBOSA, Eunice. Evolução do uso residencial na área central do Município de São Paulo. São Paulo, Dissertação (Mestrado), Escola Politécnica da Universidade de São Paulo, 2001.

BOMTEMPI, Sylvio. O bairro de São Miguel Paulista. São Paulo, Departamento de cultura da Secretaria de Educação e Cultura. Série História dos Bairros, vol. VII, 1970.

BRANCO, Plínio A. O racionamento de energia elétrica. São Paulo, Prefeitura do Município de São Paulo, 1951.

CAMPOS FILHO, Cândido Malta. Cidades Brasileiras: seu controle ou o caos: o que os cidadãos devem fazer para a humanização das cidades no Brasil. São Paulo: Studio Nobel, 2 ed., 1992.

CARDOSO JR. Joaquim Faria. Normas e Especificações para a Elaboração de Projetos de Esgotos Sanitários para a Área Metropolitana da Capital de São Paulo. 
Revista do DAE. São Paulo, Repartição de Águas e Esgoto de São Paulo Secretaria de Viação e Obras Públicas. Número 37, pg. 9/11; 23/26, Março, 1960.

COMPANHIA DE GÁS DE SÃO PAULO - COMGÁS. Gás Natural Mais Energia para São Paulo. São Paulo, (apostila) Comgás, 1997.

COMPANHIA DE SANEAMENTO BÁSICO DO ESTADO DE SÃO PAULO.

Histórico. Página da Internet. Endereço de acesso: http://www.sabesp.com.br, 2000/2002.

Noticiário SABESP. Revista do DAE. São Paulo, Repartição de Águas e Esgoto de São Paulo - Secretaria de Viação e Obras Públicas. Número 112, pg. 19, 1977.

. Noticiário SABESP. Revista do DAE. São Paulo, Repartição de Águas e Esgoto de São Paulo - Secretaria de Viação e Obras Públicas. Número 115, pg. 13, 1978.

- Dados Estatísticos. Revista do DAE. São Paulo, Repartição de Águas e Esgoto de São Paulo - Secretaria de Viação e Obras Públicas. Número 116, pg. 13, 1978.

A Evolução do Planasa em São Paulo no ano de 1975. Revista do

DAE. São Paulo, Repartição de Águas e Esgoto de São Paulo - Secretaria de Obras e Meio Ambiente. Número 104, pg. 44, 1976.

. Metas para o Abastecimento de Água da Região Metropolitana 1975-78. São Paulo, Secretaria de Obras e Meio Ambiente. Folheto: Água para a Grande São Paulo, 1976.

Mapa da Rede de Abastecimento de Água, SABESP, 1995.

Mapa da Rede de Coleta de Esgotos, SABESP, 1995.

COMPANHIA ENERGÉTICA DE SÃO PAULO - CESP. Anuário Estatístico de Energia Elétrica e gás canalizado: consumo por município do Estado de SP. São Paulo, Cesp, 1997.

COMPANHIA ENERGÉTICA DE SÃO PAULO - CESP. Seminário Nacional de Distribuição de Energia Elétrica. São Paulo, Cesp, 1997.

CORDEIRO, Helena Kohn. O Centro da Metrópole paulistana. São Paulo, Tese (Doutorado), Faculdade de Arquitetura e Urbanismo da Universidade de São Paulo, 1978.

COTTRELL, William Frederick. Energy and society. Nova Iorque, Mcgraw, 1955. 
DEAR, Michael; FLUSTY, Steven. Postmodern urbanism. Oxford, Annals of the association of American geographers, 1998, pg. 50-72.

DEPARTAMENTO DE ÁGUAS E ESGOTOS DE SÃO PAULO - Plano Geral de Tratamento de Esgotos da Cidade de São Paulo. Revista do DAE . São Paulo, Repartição de Águas e Esgoto de São Paulo - Secretaria de Viação e Obras Públicas. Número 31, Julho, 1958.

DERTÔNIO, Hilário. O bairro do Bom Retiro. São Paulo, Departamento de Cultura da Secretaria de Educação e Cultura. Série História dos bairros, vol. IX, s/d.

DOREA, Augusta Garcia Rocha. Aclimação. São Paulo, Departamento de Cultura da Secretaria de Educação e Cultura. Série História dos bairros, vol. XIX, s/d.

ELETROPAULO METROPOLITANA ELETRICIDADE E SERVIÇOS. A Cidade da Light 1899-1930. Volumes I e II. São Paulo, Divisão de Preservação do Patrimônio Arquitetônico - Departamento do Patrimônio Histórico, 1990.

A Cidade Iluminada: tecnologia e política a serviço da Light no início do século. São Paulo, Divisão de Preservação do Patrimônio Arquitetônico - Departamento do Patrimônio Histórico, 1989.

EMPRESA BRASILEIRA DE TELECOMUNICAÇÕES - EMBRATEL. Histórico. Página da Internet. Endereço de acesso: http://www.embratel.br, 2000.

EMPRESA METROPOLITANA DE PLANEJAMENTO - EMPLASA. Sumário de Dados da Grande São Paulo. São Paulo, 1977/1998.

Paulo, 1993.

.Reconstituição da memória estatística da Grande São Paulo. São

FERREIRA, Barros. O nobre e antigo bairro da Sé. São Paulo, Departamento de Cultura da Secretaria de Educação e Cultura. Série História dos bairros, vol. X, s/d.

FUNDAÇÃO ESTADUAL DE ENGENHARIA DO MEIO AMBIENTE DO RIO DE JANEIRO. Vocabulário Básico de Meio Ambiente. Rio de Janeiro, Petrobrás, Serviço de Comunicação Social, 1991.

GARCIAS, Carlos Mello. Indicadores de qualidade dos serviços de infraestrutura de saneamento. Tese (Doutorado), Escola Politécnica da Universidade de São Paulo, 1991.

GIOZZA, William F. Fibras ópticas: tecnologia e projeto de sistemas. São Paulo, Makron, 1991. 
GRAZIA, Grazia de. (org.). Direito à cidade e meio ambiente. In: Forum Brasileiro de Reforma Urbana. Rio de Janeiro, s.ed., 1993.

GUIMARÃES, Laís de Barros Monteiro. Liberdade. São Paulo, Departamento de Cultura da Secretaria de Educação e Cultura. Série História dos bairros, vol. XVI, 1978.

HARRIS, Richard; LEWIS, Robert. Constructing a falt (y) zone: misrepresentations of American cities and suburbs, 1900-1950. Oxford, Annals of the association of American geographers, 1998, pg. 622-639.

HOMEM, Maria Cecília Naclerio, Higienópolis: grandeza e decadência de um bairro paulistano. São Paulo, Departamento de Cultura da Secretaria de Educação e Cultura. Série História dos bairros, vol. XVII, 1980.

INSTITUTO BRASILEIRO DE GEOGRAFIA E ESTATÍSTICA - IBGE. Censo Predial. Região Sudeste. São Paulo, IBGE, 1970.

2001.

Censo 2000. Indicadores socioeconômicos. São Paulo, IBGE,

INSTITUTO CUltURAL ITAÚ. Praça da República. Cadernos Cidade de São Paulo, vol.13, 1995.

JORGE, Clóvis de Athayde. Consolação: uma reportagem histórica. São Paulo, Departamento de Cultura da Secretaria de Educação e Cultura. Série História dos bairros, vol. XXII, s/d.

Luz: notícias e reflexões. São Paulo, Departamento de Cultura da Secretaria de Educação e Cultura. Série História dos bairros, vol. XXVII, 1988.

Santa Ifigênia. São Paulo, Departamento de Cultura da Secretaria de Educação e Cultura. Série História dos bairros, vol. XXIII, s/d.

LEÃO, Mário Lopes. Revisão das tarifas do serviço Telefonico da Cidade de São Paulo. São Paulo, Revista dos Tribunais, 1941.

LOPES, Helena Q.F.; TOLEDO, Vera L.V.. Itaim Bibi. São Paulo, Departamento de Cultura da Secretaria de Educação e Cultura. Série História dos bairros, vol. XXVI, 1988.

LUCENA, Célia Toledo. Bairro do Bexiga. A sobrevivência cultural. São Paulo, Editora Brasiliense, 1984

MARTINS, Antonio Egídio. São Paulo antigo: 1554 a 1910. São Paulo, Conselho de Cultura, s/d. 
MARZOLA, Nadia. Bela Vista. São Paulo, Departamento de Cultura da Secretaria de Educação e Cultura. Série História dos bairros, vol. XV, s/d.

MASCARÓ, Juan Luis. Custos de Infra-Estrutura: um ponto de partida para o desenho econômico urbano. São Paulo, Tese (Doutorado), Faculdade de Arquitetura e Urbanismo da Universidade de São Paulo, 1979.

- Desenho Urbano e custos de urbanização. Brasília, Ministério da Habitação, Urbanismo e Meio Ambiente, 1987.

Infra-Estrutura Habitacional Alternativa. Porto Alegre, Editora Sagra, 1991. Pg. 14, 21, 22.

MENEZES, Luiz Carlos C.. Saneamento básico, saúde pública e qualidade de vida. Considerações. Revista do DAE. São Paulo, Repartição de Águas e Esgoto de São Paulo - Secretaria de Viação e Obras Públicas. Número 136, pg. 15-19, Março, 1984.

MESQUITA, Lauro. A infra-estrutura completa é o grande patrimônio do centro. Revista Urbs. São Paulo, Associação Viva o Centro, Janeiro, 1998. Pg 36/39.

MIGLIORINI, Vera Lúcia Blat. Os padrões de desempenho do uso e ocupação do solo na previsão e controle de adensamento de áreas intra-urbanas Tese (Doutorado), Escola Politécnica da Universidade de São Paulo, 1997.

MORETTI, Ricardo de Souza. Critérios de Urbanização para empreendimentos habitacionais. Tese (Doutorado), Escola Politécnica da Universidade de São Paulo, 1993.

MORSE, Richard. Formação Histórica de São Paulo. Da comunidade a metrópole. São Paulo, s.ed., 1954.

MOSES, Robert. Programa de melhoramentos públicos para a Cidade de São Paulo. New York : Internat Basic Economy Corporation, 1950.

MOTTA, Antenor. O abastecimento de água em São Paulo (Brasil). Boletim Técnico da RAE. São Paulo, Repartição de Águas e Esgoto de São Paulo - Secretaria de Viação e Obras Públicas. Número 2, pg. 203/205, Março, 1937.

MOTTA, Arthur. Estudos Preliminares para o reforço do abastecimento d'água na cidade de São Paulo. São Paulo, S.N., 1911.

MUNFORD, Lewis. City in history. Nova Iorque, Horizon, 1961.

- The Culture of the cities. Nova Iorque, Harcourt, Brace and company, 1938. 
MUSEU DO TELEFONE - COMPANHIA TELEFÔNICA DO ESTADO DE SÃO PAULO. Museu do Telefone. São Paulo, Telesp, 1977.

NET BRASIL - Divisão NET SÃO PAULO. Lista de distritos servidos por tv a cabo. Área cabeada pela Net, 1999. Página da Internet. Endereço de acesso: http://www.net.tv.br, 2000.

NIJMAN, Jan. The paradigmatic city. Oxford, Annals of the association of American geographers, 2000, pg. 135-145.

NOBRE, Eduardo Alberto Cuce. Reestruturação Econômica e Território: expansão recente do terciário na Marginal do Rio Pinheiros. São Paulo, Tese (Doutorado), Faculdade de Arquitetura e Urbanismo da Universidade de São Paulo, 2000.

NOVAES, Henrique de. Relatório da Comissão de Obras novas do abastecimento de água da Capital. São Paulo, TYP. Brazil, 1927.

NUCCI, Nelson Luiz Rodrigues. Avaliação da demanda urbana de água. Aspectos econômicos e urbanísticos. A área edificada como possível variável explicativa e prospectiva. Revista do DAE. São Paulo, Repartição de Águas e Esgoto de São Paulo - Secretaria de Viação e Obras Públicas. Número 135, pg. 22-29, Dezembro, 1983.

Equipamentos urbanos de água e esgotos no estado de São Paulo. São Paulo, Cibpu, 1963.

OSEKI, Jorge Hajime. Espaço das redes de serviços urbanos. São Paulo, Uncrd/Fau-Usp/Fupam, 1992. 1 Pg.129-141.

PACHECO, José Aranha de Assis. Perdizes: História de um bairro. São Paulo, Departamento de Cultura da Secretaria de Educação e Cultura. Série História dos bairros, vol. XXI, 1982.

PENTEADO, Jacob. Belenzinho 1910 (retrato de uma época). Editora?, 1962.

PONTES, Luiz Augusto de Lima. Reformas fundamentais na Administração dos Sistemas de Água e Esgotos da Cidade de São Paulo. Revista do DAE. São Paulo, Repartição de Águas e Esgoto de São Paulo - Secretaria de Viação e Obras Públicas. Número 76, pg. 241, Junho, 1970.

PREFEITURA DO MUNICÍPIO DE SÃO PAULO, PMSP. Lapa: evolução histórica. São Paulo, Departamento do Patrimônio Histórico de São Paulo. Série Registros n. 12, 1988.

Plano Urbanístico Básico. Consórcio Asplan, Daily, Montreal, Wilbur Smith, voume.2 -Desenvolvimento Urbano, 1968.

- Plano Urbanístico Básico. Consórcio Asplan, Daily, Montreal, Wilbur Smith, volume.5 - Infra-Estrutura, 1968. 
- Planos para cinco regiões administrativas do Município de São

Paulo. PMSP, 1986.

Relatório da Gestão Ademar de Barros 1958 -1961.PMSP, 1961.

QUEIROZ, Victor Oscar de Seixas. Abastecimento de Água na Cidade de São Paulo. Revista do DAE. São Paulo, Repartição de Águas e Esgoto de São Paulo Secretaria de Viação e Obras Públicas. Número 52, pgs. 29/48, Março, 1964.

RAMOS, C.R.M., et al. Estudo para regionalização dos serviços de operação e Manutenção de Água e Esgotos. Revista do DAE. São Paulo, Repartição de Águas e Esgoto de São Paulo - Secretaria de Viação e Obras Públicas. Número 72, pg. 49, 57 e 59, Junho, 1969.

REALE, EBE. Brás, Pinheiros e Jardins: três bairros, três mundos. São Paulo, Editora da Universidade de São Paulo, 1982.

RODRIGUEZ, Cleide S., Comgás planeja triplicar receita nos próximos três anos. São Paulo. Jornal O Estado de São Paulo, 27 de maio de 1999.

ROLNIK, Raquel. A Cidade e a Lei: legislação, política urbana e territórios na Cidade de São Paulo. São Paulo, Studio Nobel Fapesp, 1997. , et al. São Paulo: crise e mudança. São Paulo, Editora Brasiliense,

1991.

RONCA, Luiz C.; ZMITROWICZ, Witold. Análise dos Limiares em planejamento urbano. São Paulo, Boletim Técnico, Escola Politécnica da Universidade de São Paulo, 1988.

SANTIAGO, Francisco, A. Quadro dos reservatórios que abastecem a cidade de São Paulo. Revista do DAE. São Paulo, Repartição de Águas e Esgoto de São Paulo Secretaria de Viação e Obras Públicas. Número 52, pg. 54/55, Março, 1964.

SÃO PAULO (CIDADE) - SECRETARIA MUNICIPAL DO PLANEJAMENTO. Plano do Município de São Paulo 1985/2000. São Paulo, Prefeitura do Município de São Paulo, SEMPLA. Série Documentos, pg. 126/130, 1985.

- COMPANHIA DE PROCESAMENTO DE DADOS DO MUNICÍPIO DE SÃO PAULO - PRODAM. Atlas Ambiental. Cd-rom. São Paulo, PMSP, 2001.

- COMPANHIA DE PROCESAMENTO DE DADOS DO MUNICÍPIO DE SÃO PAULO - PRODAM. Informações urbanas. Página da Internet. Endereço de acesso: http://www.prodam.sp.gov.br, $2000 / 2002$.

- COORDENADORIA GERAL DE PLANEJAMENTO - COGEP.

Administrações Regionais, 16 volumes. São Paulo, PMSP, 1975. 
- SECRETARIA MUNICIPAL DE PLANEJAMENTO - SEMPLA. Diagnóstico regionalizado do município de São Paulo. São Paulo, PMSP, 1983.

- SECRETARIA MUNICIPAL DE PLANEJAMENTO - SEMPLA. Evolução do Uso do Solo nos anos 90. São Paulo, PMSP, 2000/01.

- SECRETARIA MUNICIPAL DE PLANEJAMENTO - SEMPLA. Geolog Aplicações Geográficas. São Paulo, PMSP, 2000/01.

SECRETARIA MUNICIPAL DE PLANEJAMENTO SEMPLA. Perfil socioeconômico do Município de São Paulo. São Paulo, PMSP, 2000/01.

- DEPARTAMENTO DE ILUMINAÇÃO PÚBLICA - ILUME. Pontos com pedido de manutenção / ligação no Município de São Paulo, 1997. São Paulo, 2001.

SÃO PAULO (ESTADO) - DEPARTAMENTO DE ÁGUAS E ENERGIA ELÉTRICA. Distribuição de água e coleta de esgotos em São Paulo : afastamento e disposição de esgotos na área metropolitana. São Paulo, DAEE (BSP) Superintendência, 1970.

- DEPARTAMENTO DE ÁGUAS E ENERGIA ELÉTRICA. DAEE: uma autarquia em desenvolvimento. São Paulo, DAEE, 1982.

- IMPRESSA OFICIAL. Mais verbas para obras de saneamento. Diário oficial do Estado de São Paulo, v.112, n.98, 25 de maio de 2002, p.112.

- SECRETARIA DE PLANEJAMENTO. Atlas Regional da Grande São Paulo - Mapa 11 - Energia. São Paulo, Governo do Estado de SP, 1980.

- SECRETARIA DE CIÊNCIA, TECNOLOGIA E DESENVOLVIMENTO ECONÔMICO. Campos Elíseos: a casa e o bairro - A tecnologia da construção em 1900. São Paulo, Governo do Estado de SP, s/d.

SAVELLI, Mário. Histórico do aproveitamento das águas da região paulistana. Revista do DAE. São Paulo, Repartição de Águas e Esgoto de São Paulo - Secretaria de Viação e Obras Públicas. Número 53, pg. 82/87, Junho, 1964.

SCHALCH, José Emiliano. Revisão das Redes de Esgoto da Cidade de São Paulo. Boletim Técnico da RAE. São Paulo, Repartição de Águas e Esgoto de São Paulo - Secretaria de Viação e Obras Públicas. Número 8, pg. 15/19, Dezembro, 1939.

SILVA, Hippólyto da. Sinopse do Relatório de 1939. Boletim Técnico da RAE. São Paulo, Repartição de Águas e Esgoto de São Paulo - Secretaria de Viação e Obras Públicas. Número 11, pg. 155/183, Setembro, 1940. 
TOLEDO SILVA, Ricardo. A conectividade das redes de infra-estrutura e o espaço urbano de São Paulo. Rio de Janeiro, Revan / FASE, 2000. Pg. 407-432.

. Habitação, infra-estrutura urbana e regulação pública: limites da privatização. Tese (Doutorado), Faculdade de Arquitetura e Urbanismo da Universidade de São Paulo, 1991.

Oferta de infra-estrutura e revitalização do centro: aspectos da gestão e do controle social. São Paulo, São Paulo século XXI, Associação Viva o Centro, 1995. Pg. 19.

Utilities regulation and urban segregation. Research notes on the brazilian urban context. Seminário Internacional: Globalization, urban form end governance, 2000, p. 225-242.

SOCRATES, Jodete Rios. Uso do solo em São Paulo :um modelo gráfico de estrutura urbana. São Paulo, Dissertação (Mestrado) - Faculdade de Arquitetura e Urbanismo da Universidade de São Paulo, 1983.

SOUZA, Edgard Egydio de. História da Light - primeiros 50 anos. São Paulo, Divisão de Preservação do Patrimônio Arquitetônico - Departamento do Patrimônio Histórico, $3^{\mathrm{a}}$ edição, 1989.

SOUZA, Luiz Felipe Proost de. Variáveis ambientais e o valor da terra. O caso do rio Tamanduateí. Dissertação (Mestrado). Saneamento Ambiental. Universidade Presbiteriana Mackenzie, 2000.

SOUZA, Maria Adélia. A identidade da Metrópole. Editora Hucitec, Universidade de São Paulo, 1994.

TELEFONICA. Centrais Telefônicas no Estado de São Paulo - 1999. São Paulo, 2001.

TELLES, Pedro Carlos da Silva. História da Engenharia no Brasil - século XVI a XIX. Rio de Janeiro, Clube de Engenharia, vol. 1, 1984. Pg. 347/363; 366/370.

- História da Engenharia no Brasil - século XX. Rio de Janeiro, Clube de Engenharia, vol. 2, 1984.

THOMPSON, Oswaldo B. Dados sobre o abastecimento de Água de São Paulo. Boletim Técnico da RAE. São Paulo, Repartição de Águas e Esgoto de São Paulo - Secretaria de Viação e Obras Públicas. Número 9, pg. 32/48, Março, 1940.

TORRES, Maria Celestina Teixeira Mendes. Ibirapuera. São Paulo, Departamento de Cultura da Secretaria de Educação e Cultura. Série História dos bairros, vol. XI, s/d.

VARGAS, Milton. Metodologia da pesquisa tecnológica. Rio de Janeiro, Ed.Globo, 1985. 
VETTER, David Michael. Espaco, valor da terra e equidade dos investimentos em infraestrutura urbana:uma análise do Município do Rio de Janeiro. Rio de Janeiro, Departamento de Estatística e Indicadores Sociais, s.d.

VIANA, Myrna T.R. São Miguel Paulista: o chão dos desterrados. São Paulo, Dissertação (Mestrado), Faculdade de Filosofia, Letras e Ciências Humanas da Universidade de São Paulo, 1982.

VILLAÇA, Flávio José Magalhães. Estruturação da Metrópole Sul Brasileira. Coletânea de Mapas, baseada na Tese (Doutorado). Faculdade de Filosofia, Letras e Ciências Humanas da Universidade de São Paulo, 1978

Espaço intra-urbano no Brasil. São Paulo, Studio Nobel, 1998.

Uso do Solo. São Paulo, Faculdade de Arquitetura e Urbanismo da Universidade de São Paulo, 1968.

WHITAKER, Plínio Penteado. Abastecimento de água desta Capital. Boletim Técnico da RAE. São Paulo, Repartição de Águas e Esgoto de São Paulo Secretaria de Viação e Obras Públicas. Número, pg. 3/15, Dezembro, 1952.

Abastecimento de água na Cidade de São Paulo. Sua Solução. Boletim Técnico da RAE. São Paulo, Repartição de Águas e Esgoto de São Paulo Secretaria de Viação e Obras Públicas. Número 17, pg. 3/22, Novembro, 1946.

Relatório referente ao ano de 1942. Boletim Técnico da RAE. São

Paulo, Repartição de Águas e Esgoto de São Paulo - Secretaria de Viação e Obras Públicas. Número 12, pg. 24/35, Março, 1943.

YASSUDA, Eduardo Riomey. Projeto de Abastecimento de água para a região metropolitana de São Paulo 1975-78. Revista do DAE. São Paulo, Repartição de Águas e Esgoto de São Paulo - Secretaria de Viação e Obras Públicas. Número 106, pg. 24/27, 1976.

ZMITROWICZ, Witold. As funções Urbano-Rurais como Condicionantes da Implantação de Zoneamento na Cidade de São Paulo. São Paulo, Dissertação (Mestrado), Escola Politécnica da Universidade de São Paulo, 1979.

; ANGELIS NETO, Generoso de. Infra-Estrutura Urbana. São Paulo, Texto Técnico, Escola Politécnica da Universidade de São Paulo, 1997.

. (org.). Meio Ambiente - Custos e Limites de Urbanização. São

Paulo, Coleção Documentos - Série Estudos Urbanos n. 6. Instituto de Estudos Avançados da Universidade de São Paulo, 1992.

. Obras públicas de engenharia e sua função na estruturação da cidade de São Paulo. São Paulo, Tese (Doutorado), Escola Politécnica da Universidade de São Paulo, 1984. 


\section{ANEXO - Figuras e CD-ROM}

\section{Figuras $^{113}$}

No trabalho com os mapas coletados, visando a confecção do sistema de "camadas", alguns processos foram pesquisados. Partimos do que seria o mais preciso no que diz respeito ao trabalho com mapas em camadas de diferentes escalas, que consiste em utilizar o chamado SIG (Sistema de Informações Geográficas) para através de geoprocessamento, localizar os mapas segundo coordenadas e a seguir processá-los em programas como por exemplo o IDRISI (programa de digitalização compatível com o Windows ) para criação dos layers. Este processo, sendo extremamente exato, propiciaria que ao clicar uma parte do mapa, houvesse acesso a dados numéricos sobre área, população, etc. que poderiam ser interessantes. Mas, devido a falta de domínio sobre o programa e sendo grande o número de mapas para digitalizar, outro meio, mais simples e rápido - embora menos exato - foi o escolhido para a execução do Cd-Rom. Trata-se do Adobe PhotoShop ${ }^{114}$ e do sistema de criação de páginas na Internet. Este método não permite o georeferenciamento e o acesso a dados numéricos, mas permite a execução da sobreposição de diferentes mapas e a impressão dos mesmos, segundo as seguintes etapas:

1. Transformação dos Mapas para a mesma escala, de preferência em tamanho A3 ou A4;

2. Cópia de cada mapa em scanner, apagando contornos indesejados e que podem interferir na sobreposição;

3. Trabalho com o Adobe PhotoShop, base de criação dos "layers":

- Mudar cor das manchas ressaltando os diferentes períodos;

- Igualar tamanho das figuras a sobrepor;

- Abrir simultaneamente todos os mapas que devem ser sobrepostos e selecionar um deles;

- Criar um novo Layer.

\footnotetext{
113 Aqui se faz necessária a distinção entre "mapas" e "figuras". De forma simplificada, os "mapas" são exatos, possuindo um referencial e na pior das hipóteses uma simples escala gráfica. Já as "figuras" como elaboramos, apenas indicam manchas genéricas, que respeitam um certo grau de precisão mas não podem ser utilizados como base de estudos minuciosos.

114 Bibliografia de apoio: BOUTON, Gary David; BOUTON, Bárbara. Inside Adobe Photoshop 5. New Riders Publishing, Indianapolis, Indiana, 1998.
} 
A dificuldade foi igualar o tamanho dos vários mapas e definir qual a prioridade de "transparência" visando que a impressão fique legível.

Lembramos mais uma vez que a intenção é a de mostrar a expansão em função de manchas que somente darão uma idéia da evolução dos serviços; a escala pode apresentar problemas e pequenas distorções.

A escolha do mapa com as represas, áreas verdes e os distritos definidos em 1991, fornece uma idéia da cidade atual, mas vale lembrar que, por exemplo, em 1900 a cidade era bem diferente ${ }^{115}$.

\section{Figuras Base}

Base 1: mapa contendo o nome dos distritos segundo a divisão de 1991

Base 2: parques/ áreas verdes significativas e hidrografia ${ }^{116}$.

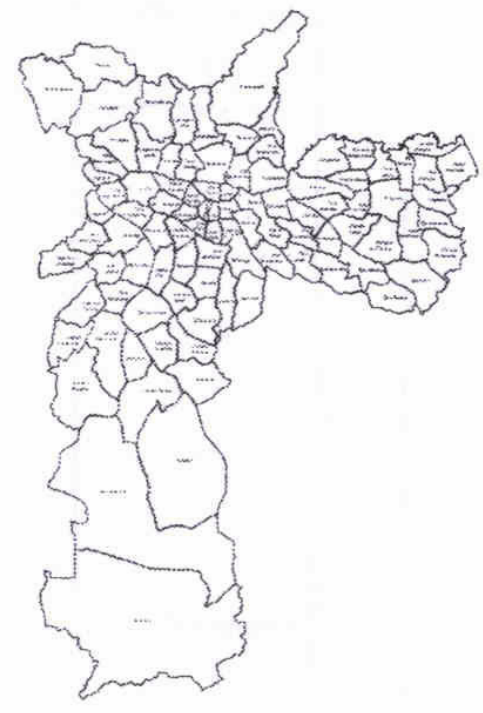

Mapa 1

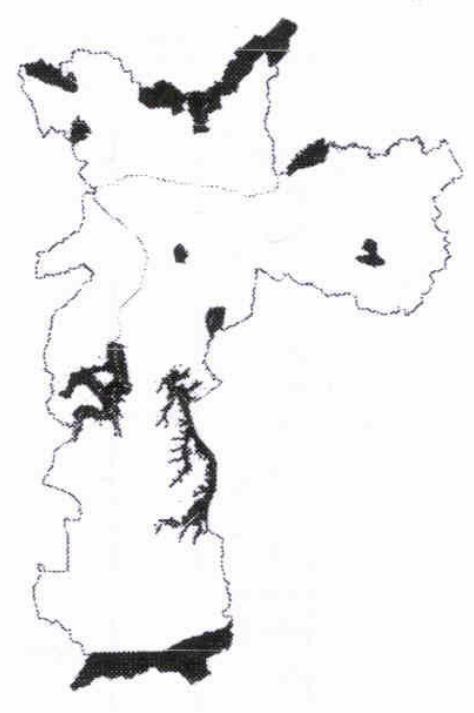

Mapa 2

Fonte:

SEMPLA, 2000.

Nota: figura sem escala

\footnotetext{
${ }^{115}$ A inexistência de mapas com a mancha urbana que coincidam exatamente com as datas dos mapas de infra-estrutura, impossibilitou a comparação gráfica entre expansão da população e velocidade de implantação das redes.

${ }^{16}$ Os parques / áreas verdes representados são: Reserva da Cantareira, Parque Anhanguera, Parque Jaraguá, Parque Ecológico do Tietê, Parque Ibirapuera, Parque do Carmo, Parque do Estado, Parque Ecológico do Guarapiranga e no extremo sul, a Reserva Curucutu. Na hidrografia: rios Tietê e Pinheiros e a represa de Guarapiranga.
} 


\section{Cd-Rom}

Através da criação de menu e sub-menus usando o programa Microsoft FrontPage, elaboramos várias páginas interligadas, propiciando a organização das figuras por tipo de rede e período.

Página de apresentação do cd-rom

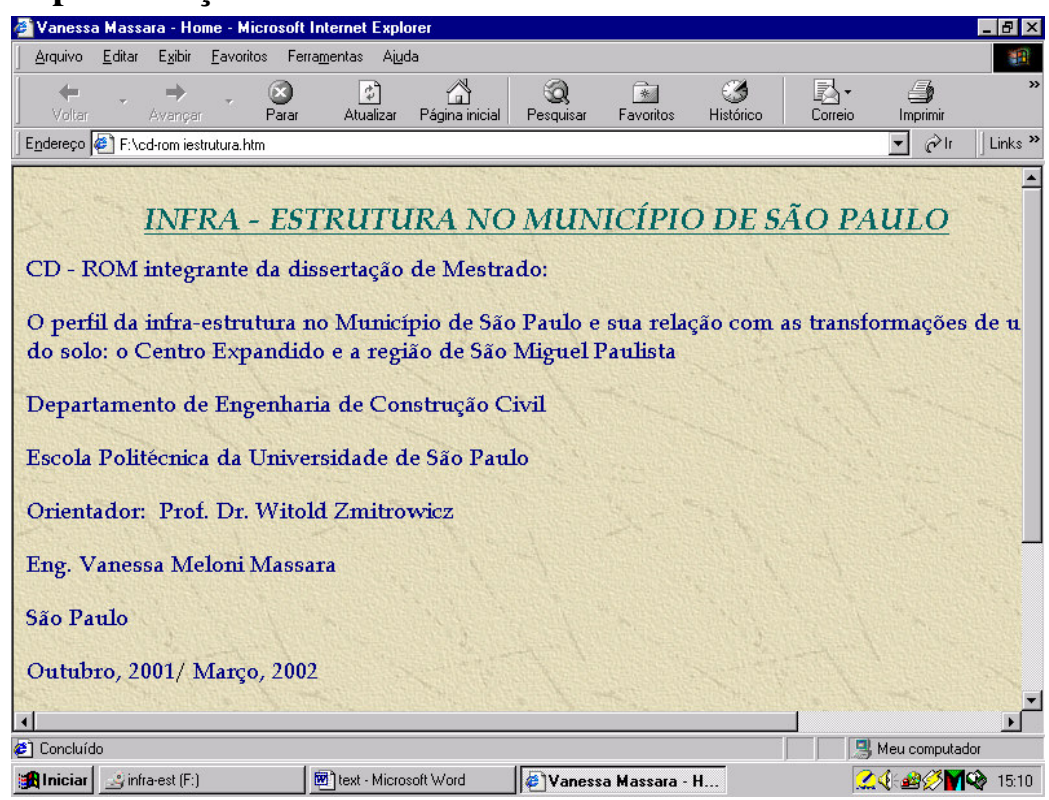

Primeiro sub-menu: Introdução, Distribuição territorial das redes de infra-estrutura, Referências bibliográficas, Agradecimentos, Notas (observações)

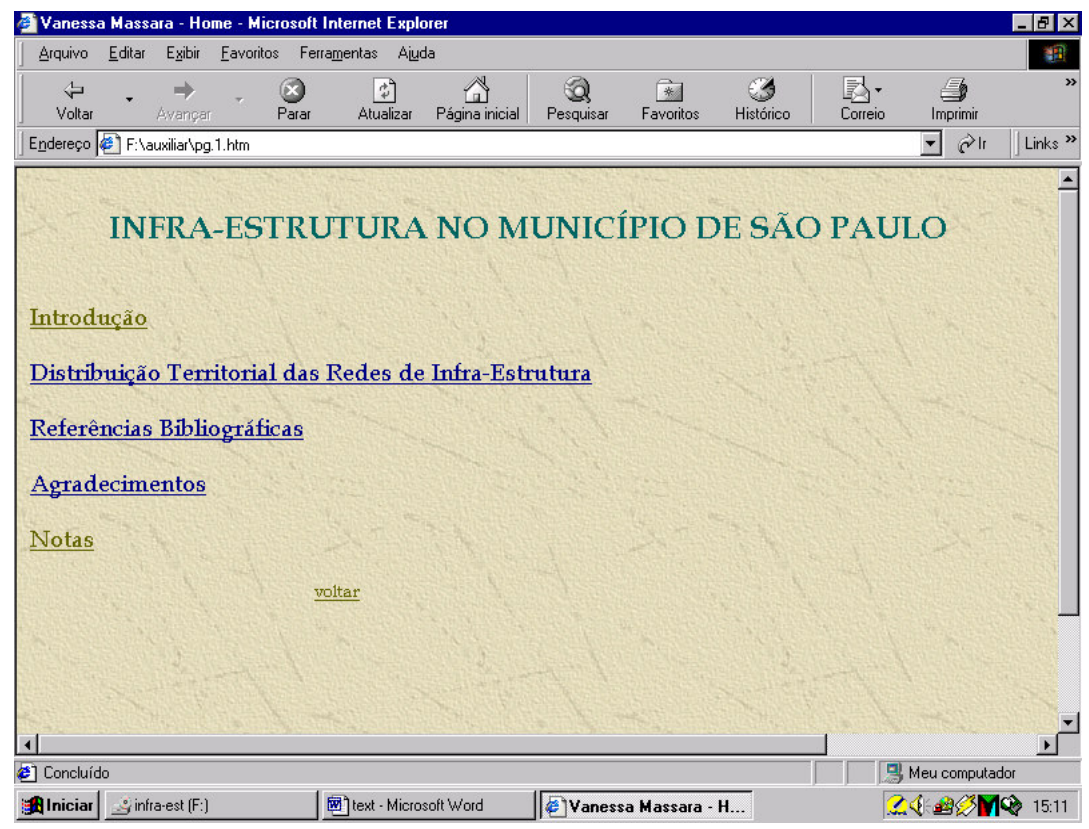


Segundo sub-menu: Distribuição Territorial das redes de infra-estrutura: rede de abastecimento de água (1900, 1928, 1958, 1975, 1995, 2000);rede de coleta de esgotos (1900, 1928, 1958, 1975, 1995, 2000); rede de iluminação pública (1900, 1958, 1975, 1997); rede de gás canalizado (1958, 1975, 1999 / 03); distritos servidos por tv a cabo (1999); centrais telefônicas (1999); estações transformadoras de energia elétrica (1980).

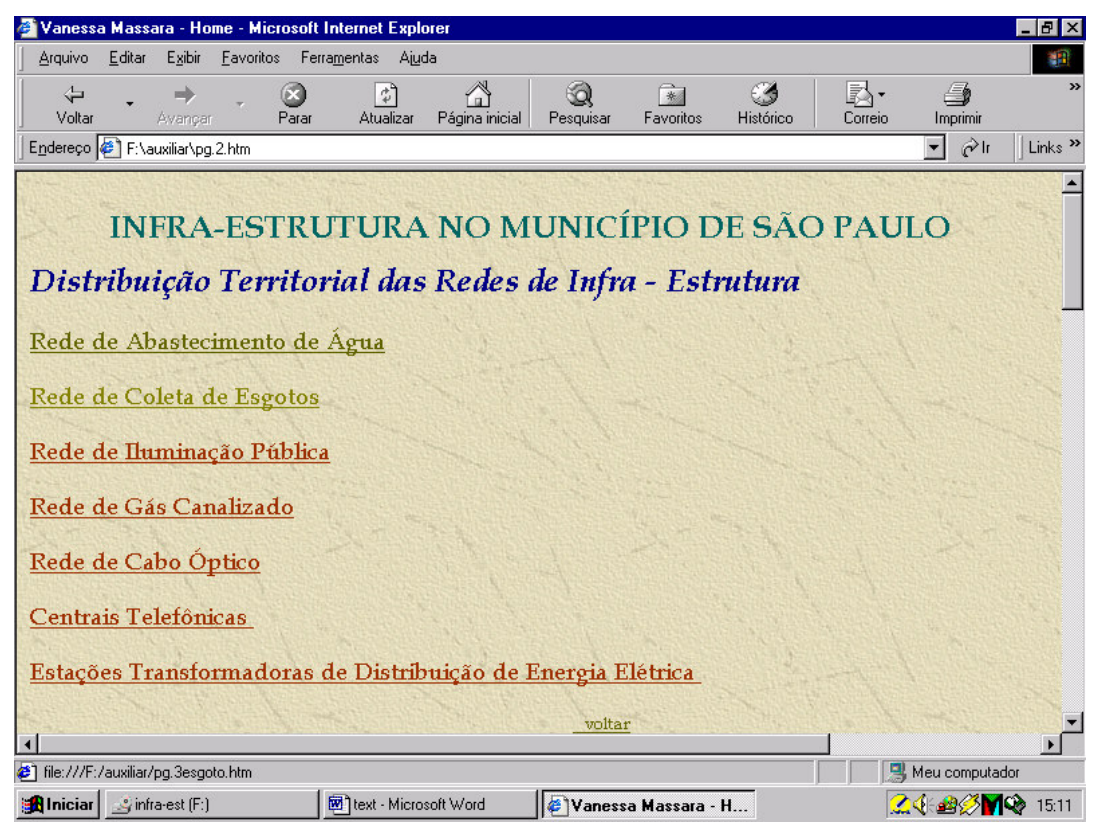

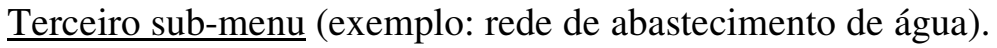

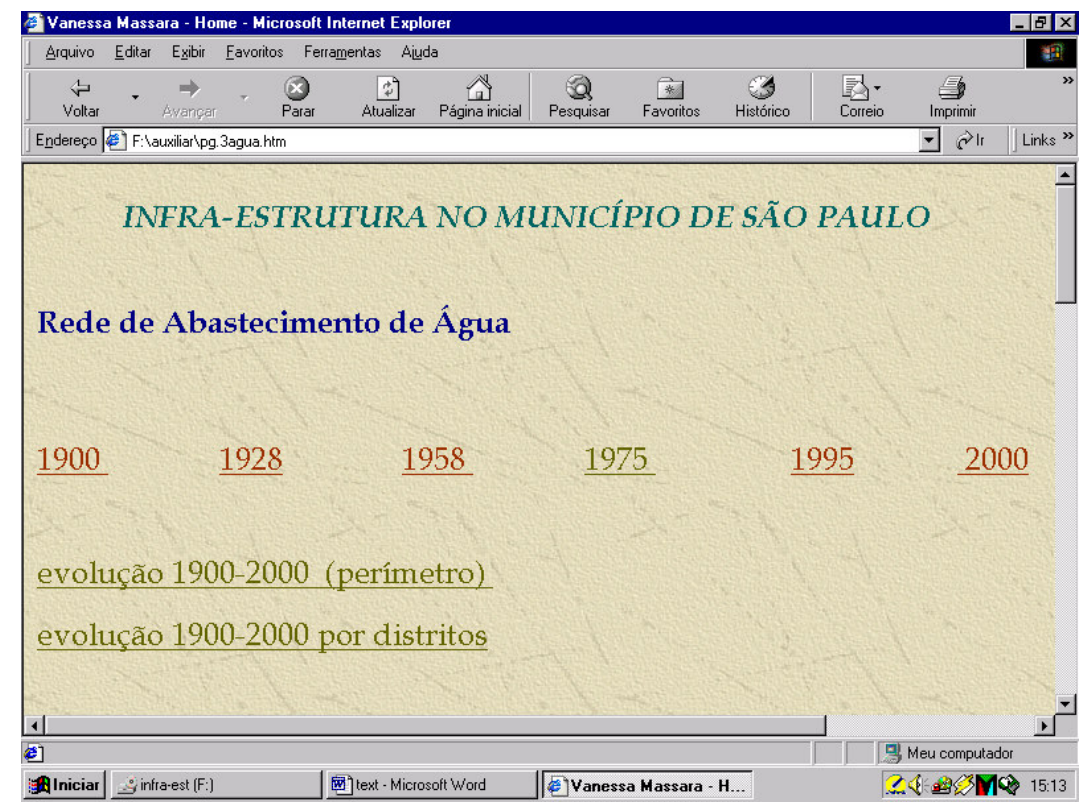


Quarto sub-menu (exemplo: evolução da distribuição territorial da rede de abastecimento de água no período 1900-2000).

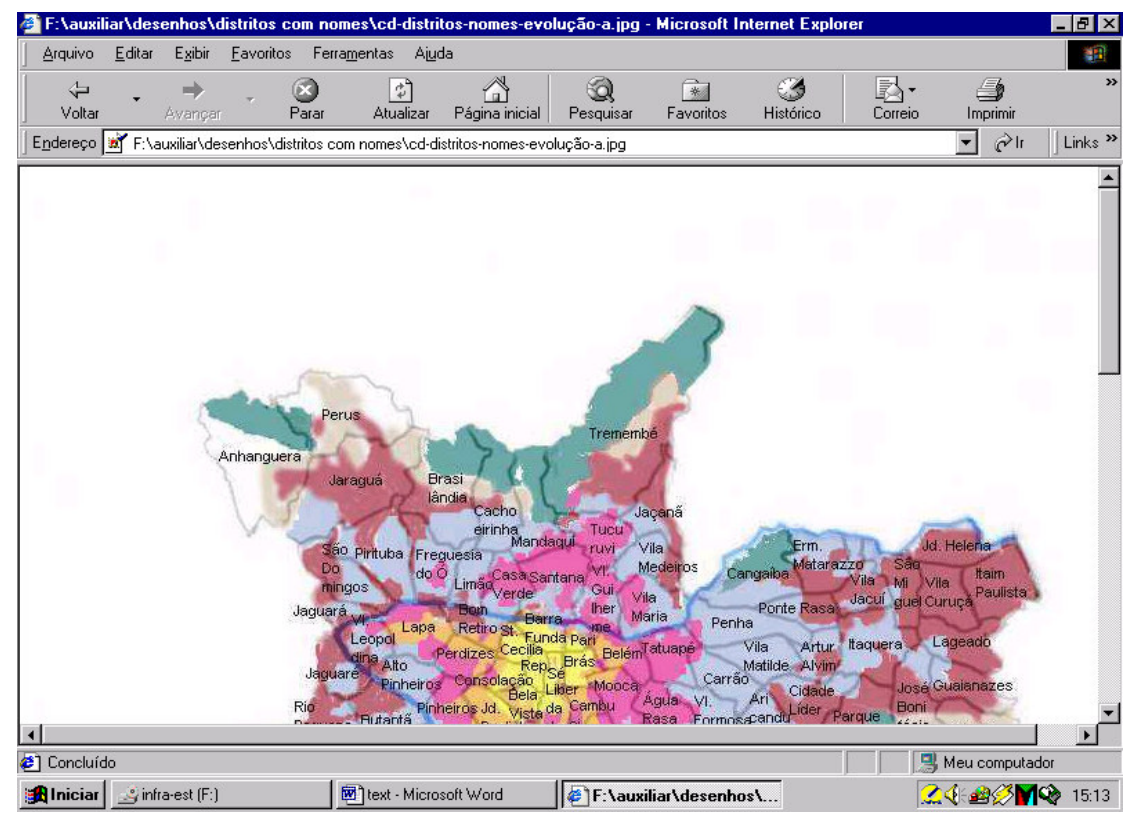

$\underline{\text { Instruções para leitura do cd-rom }}$

1) Instale o disco em um drive leitor de cd;

2) Abra o cd (intitulado infra-est);

3) Abra o arquivo intitulado cd-rom iestrutura.

Obs.: É necessário que o computador tenha o programa Internet Explorer.

Aconselhamos que a eventual impressão das figuras seja em impressora colorida e que seja feita a configuração da página para perfeita impressão da figura (Acionar: arquivo $\rightarrow$ configurar página $\rightarrow$ tamanho do papel $210 \times 297 \mathrm{~mm})$.

NOTA: Este cd-rom está disponível para consulta e empréstimo nas bibliotecas da Escola Politécnica da Engenharia Civil e Central. 